\title{
Hanford Patrol Academy Demolition Sites Closure Plan
}

\author{
Date Published \\ December 1994
}

\section{DISCLAIMER}

This report was prepared as an account of work sponsored by an agency of the United States Government. Neither the United States Government nor any agency thereof, nor any of their employees, makes any warranty, express or implied, or assumes any legal liability or responsibility for the accuracy, completeness, or usefulness of any information, apparatus, product, or process disclosed, or represents that its use would not infringe privately owned rights. Reference herein to any specific commercial product, process, or service by trade name, trademark, manufacturer, or otherwise does not necessarily constitute or imply its endorsement, recommendation, or favoring by the United States Government or any agency thereof. The views and opinions of authors expressed herein do not necessarily state or reflect those of the United States Government or any agency thereof.

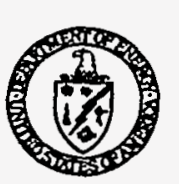

\section{United States}

Department of Energy

P.O. Box 550

Richland, Washington 99352

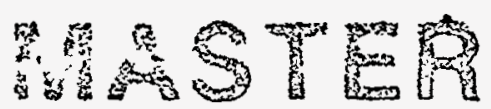

Approved for Public Release 
TRADEMARK DISCLAIMER

Reference herein to any specific commercial product, process, or service by trade name, trademark, manufacturer, or otherwise, does not necessarily constitute or imply its endorsement, recommendation, or favoring by the United States Government or any agency thereof or its contractors or subcontractors.

This report has been reproduced from the best available copy. Available in paper copy and microfiche.

Available to the U.S. Department of Energy

and its contractors from

Office of Scientific and Technical Information

P.O. Box 62

Oak Ridge, TN 37831

(615) $576-8401$

Available to the public from the U.S. Department of Commerce

National Technical Information Service

5285 Port Royal Road

Springlield, VA 22161

(703) $487-4650$

Printed in the United States of America

DISCLM-5.CHP (8-91) 


\section{DISCLAIMER}

Portions of this document may be illegible in electronic image products. Images are produced from the best available original document. 
HANFORD PATROL ACADEMY DEMOLITION SITES CLOSURE PLAN NOTICE OF DEFICIENCY RESPONSE TABLE
September 30,1993

Page 1 of 51

Concurrence
1.
Comment/Response

Deficiency: The level of detail in this closure plan is inadequate.

Requirement: Provide additional information regarding the following topics:

(1) The determination of the boundary locations.

RL/WHC Response 1: Since no written records of the location of Closure Area No. 1 were kept, nor were permanent markers placed at the time of detonations. The location of Closure Area No. 1 was established by personnel that were present during the detonation events, as stated on page 2-2, lines 46-50. Closure Area No. 2 is marked by a depression in the land surface. A1l treatment activities at this area occurred in the depression. The location of Closure Area No. 2 has not changed position as stated in line 50. Figures $\mathrm{F} 2-4$ and F2-5 show the relative locations of the two closure areas. Page 6-1, 1ine 20-22, states that the final closure area boundaries will be confirmed by the results of regulatory acceptable soil sampling and analysis.

Ecology Response 1: Concur with the adjustment of unit boundary based on sampling and analys is data for Area No. 2. Because of no hard evidences on the boundary of Area No. 1, and the regradation, initial sampling outside the so-called boundary has to be done for Area No. 1 (see also NOD No. 10 response).

Ecology/RL/WHC Resolution: At the February 12, 1994, Data Quality Objectives (DQO) meeting, RL/WHC explained that the location of Closure Area No. 1 was the northwestern most corner of what is called Closure Area no 1. The other three quadrants make up the area where any unreacted residues would have been distributed as a result of grading. Ecology accepted this explanation, therefore 
HANFORD PATROL ACADEMY DEMOLITION SITES CLOSURE PLAN NOTICE OF DEFICIENCY RESPONSE TABLE
September 30, 1993

Page 2 of 51

the boundary area was not enlarged. Al1 parties agreed to the preliminary sampling locations and analytical methods for the HPADS sampling and analysis plan (SAP). Ecology approved the final SAP on August 15, 1994.

(2) When Comprehensive Environmental Response, Compensation and Recovery Act (CERCLA) cleanup is proposed to comply with Resource Conservation and Recovery Act (RCRA) regulations, expla in in detail what will be done so that we may evaluate whether the cleanup will in fact meet RCRA requirements.

RL/WHC Response 1: Section 6.3 explains RCRA/CERCLA integration activities during closure.

Ecology Response 1: Section 6.3 didn't adequately address integration. First, Section 6.3 will be modified (see NOD No. 26 response). Second, Section 6.3, line 22-24, indicated that "If contamination levels for all constituents of concern listed in Chapter 7.0, Table 7-1, are below the action level, the HPADS will be closed." Obviously, Table 7-2 was missed in the text. The problem is that Table 7-1 did not include any contaminants from the detonation events before 1984. The argument was that there were no records kept for those events. If this is true, then, a broader range of contaminants should be sampled and tested to assure potential contaminations are not missed. Modify text to incorporate Appendix IX of 40 CFR Part 264. Finally, to make sure that nothing will be neglected, list explicitly the contaminants regulated under RCRA, and those under CERCLA.

Ecology/RL/WHC Resolution: Subsequent to the DQO negotiations, it was determined that the HPADS are not within the boundaries of a CERCLA operable unit. Section 6.3 will be revised to explain that 
HANFORD PATROL ACADEMY DEMOLITION SITES CLOSURE PLAN NOTICE OF DEFICIENCY RESPONSE TABLE
September 30, 1993

Page 3 of 51

if any contaminants not associated with the operation of the TSD unit are detected, the HPADS will be evaluated as a new SWMU and remediated as a RPP activity.

During the DQO process, all parties agreed that no records of the pre-1984 events were kept. RL/WHC explained that while no records exist, the inventory would not have been significantly different from the post-1984 events (e.g., only explosive, shock sensitive, or highly reactive chemical products were treated at the HPADS Closure Area No. 1). All parties agreed to a the analytical test methods, constituents of concern, and sample locations. The finalized SAP was issued on August 15, 1994.

(3) Action levels for constituents of concern.

RL/WHC Response 1: Action levels will be prepared for inclusion in Section 6.0 of Revision 1. Proposed action levels will be heal.th-based values.

Ecology Response 1: Although the term "action levels" is defined within the closure plan as "concentrations of analytes of interest that prompt an action . . .", the term is not defined by WAC 173303. As the closure plan addresses a RCRA unit and to avoid confusion on this subject, delete the "action level" term. It should be noted that a definition for "cleanup level" is provided by WAC 173-340-200 which may be utilized by reference of proposed WAC 173-330-610 (scheduled to promulgated in December 1993 to amend WAC 173-303-610 to include WAC 173-340-700 through 760 except 745 ).

Ecology/RL/WHC Resolution: Through the DQO process, all parties agreed that the definition of 'action levels' is levels above the 
HANFORD PATROL ACADEMY DEMOLITION SITES CLOSURE PLAN NOTICE OF DEFICIENCY RESPONSE TABLE
September 30,1993

Page 4 of 51
No. Page/Line No.

2.
Comment/Response

\section{Concurrence}

Hanford Site soil background levels identified in Hanford Site Background: Part 1, So 17 Background for Nonradioactive Analytes DOE/RL-92-24, Rev. 1, U. S. Department of Energy, Richland Operations office, Richland, Washington and Model Toxic Control Act (MTCA) (WAC 173-303) Method B residential levels.

Deficiency: Throughout the closure plan, there are references to using only a mobile laboratory for sampling and analysis. It is not stated that this is an EPA accredited lab or that any secondary or follow-up analysis will be conducted at an accredited stationary $1 \mathrm{ab}$. A mobile 1 ab cannot meet $\mathrm{SW}-846$ requirements. A mobile laboratory is a good tool for a first evaluation to determine where contamination is located. For closure, you must follow the sampling and analysis requirements of WAC 173-303-110.

Requirement: Revise the plan to require sampling and analysis to meet WAC 173-303-110. See also comments 40,51, 60, and 61 .

RL/WHC Response 1: Revised text will propose to perform initial (investigative) sampling with analytical support to be provided by the on-site Environmental Analytical Laboratory (EAL), previously referred to as the "mobile laboratory." The EAL wi11 be providing analytical Level II support, as opposed to Level III capabilities that were planned for the laboratory at the time Revision 0 of the closure plan was prepared. Tables $7-1,7-2,7 A-1$ and $7 A-2$ identify analytes of interest for initial sampling.

A separate round of confirmatory sampling will be proposed in Revision 1 of the plan. Confirmatory samples will be analyzed by an off-site, Ecology-acceptable analytical Level III laboratory. Subsequent to initial sampling and analysis and discussion of the results with Ecology, separate data quality objectives and analyte 
HANFORD PATROL ACADEMY DEMOLITION SITES CLOSURE PLAN NOTICE OF DEFICIENCY RESPONSE TABLE
September 30, 1993 Page 5 of 51

tables for confirmatory sampling will be prepared and documented as addenda to the closure plan.

Likewise, if soil removal is undertaken and verification sampling is to be carried out in support of soil removal, samples would be analyzed by an off-site analytical Level III 1aboratory. Separate data quality objectives and analyte tables would be developed for incorporation as addenda to the plan in that event.

Ecology Response 1: Concur with addition of this information in text. However, there are several more requirements needed to be satisfied: 1) Investigative sampling has to be done by level III laboratory. The EAL can only be used to support this sampling event, such as to determine the boundary of the contamination, to find the spot with the high concentration of contaminations, and so on. If initial samples at level II indicate a "no action," confirmatory level III analyses will have to be done to verify this alternative; 2) for every fifth sample, a split has to be taken and to sent off for level III analyses. This will help in determining validity of level II analyses as well as give some ICP/AA metals analyses; and 3 ) the test results should be not less than $10 \%$ CLP deliverable $S W-846$.

Ecology/RL/WHC Resolution: The mobile laboratory will not be used for these clean closure activities. All references to using the mobile laboratory will be removed. Offsite laboratories capable of EPA analytical level III will be used for all soil samples. offsite laboratory should follow the negotiated laboratory schedule listed in the Hanford Federal Facility and Consent order Tri-Party Agreement. 
HANFORD PATROL ACADEMY DEMOLITION SITES CLOSURE PLAN NOTICE OF DEFICIENCY RESPONSE TABLE
September 30, 1993

Page 6 of 51

No. Page/Line No.

Comment/Response

Concurrence

3.

Deficiency: The closure plan cites many internal Westinghouse procedural manuals. It is not clear if these documents fulfill the procedures mandated by the regulations.

Requirement: Revise the plan or provide copies of the procedures referenced.

RL/WHC Response 1: Copies of the WHC control manuals cited in closure plans were furnished to Ecology's library in Lacey. The Ecology office in Kennewick should obtain as much information as possible from the Ecology Lacey office to support the review of RCRA closure plans.

Ecology Response 1: Concur.

4. $\quad i i i / 25$

Deficiency: "idenytification" is a typographic error.

Requirement: Correct the plan.

RL/WHC Response 1: Typographical error will be corrected.

Ecology Response 1: Concur with the correction.

5. $1-1 / 12-13$

Deficiency: States that these demolition events were "a form of thermal treatment for spent or abandoned chemical waste." This is inconsistent with the waste description provided in Chapter 3 , Process Information. On page 3-1, line 10, the waste is described as "discarded explosive."

Requirement: Revise the text to resolve the contradiction. 
HANFORD PATROL ACADEMY DEMOLITION SITES CLOSURE PLAN NOTICE OF DEFICIENCY RESPONSE TABLE
September 30, 1993

Page 7 of 51

RL/WHC Response 1: Spent or abandoned wastes were never treated at HPADS. The text will be revised to state that only "discarded" explosive chemicals beyond their shelf life or which were no longer needed were treated at HPADS. With this revision the text will be consistent with the description on page 3-1.

\section{Ecology Response 1: Concur with the revision.}

6. $1-1 / 21$

Deficiency: It is stated the closure plan will present the history of the waste treated, but the plan does not present adequate information to determine if the waste has been properly designated.

Requirement: Provide sufficient information to designate the waste, including information regarding the source of the waste (i.e., process derived from), and a distinction between wastes disposed in commercial form, and those which were spent material.

RL/WHC Response 1: Waste characterization per 40 CFR 261 and WAC 173-303 is summarized in Table 4-2 and in the Part $A$ permit application. Table 4-2 was incorporated to show that the wastes treated at HPADS were amenable to thermal decomposition. As stated in the RL/WHC Response No. 1 to comment No. 5 only chemicals that were no longer needed or that were beyond their storage life were treated at HPADS.

No "spent" materials were treated at HPADS.

Ecology Response 1: Concur with the explanation that no "spent" materials were treated at HPADS. The statement "only chemicals that were no longer needed or that were beyond their storage life were treated at HPADS." should be explained further, because, 
under 40 CFR 265.382, open burning of hazardous waste (except for detonation of waste explosives) is prohibited. According to the federal regulation, "waste explosives include waste which has the potential to detonate and . . . ." The term of "amenable to thermal decomposition" used by $\mathrm{RL} / \mathrm{WHC}$ in the response was not accurate. Thus, elaborate in the text that if the chemicals in Table 4-2 satisfy the requirements.

Ecology/RL/WHC Resolution: At the DQO meeting, all parties involved agreed that the chemicals treated at the HPADS were amenable to destruction because of their physical properties. A physical properties table will be added to the revision of Chapter 4.0 .

7. $1-1 / 38-41$

Requirement: Describe how you will determine that contamination is not associated with Hanford Patrol Academy Demolition Sites (HPADS). State if RCRA post-closure care will be performed until CERCLA action takes place.

RL WWC Response 1: P1-1/Ln40 will be revised to read ". . . will be coordinated with CERCLA ...." Table 4-1 provides a summary of the wastes treated at HPADS. Any contaminants not due to the operation of HPADS, and above action level, will be considered past practice and remediated in coordination with CERCLA activities. Post closure care, if needed, will be performed as explained in Section 8.2.

Ecology Response 1: See NOD No. 1 (2) response.

\section{Ecology/RL/WHC Resolution: See Ecology/RL/WHC Resolution} NOD No $1(2)$. 
HANFORD PATROL ACADEMY DEMOLITION SITES CLOSURE PLAN NOTICE OF DEFICIENCY RESPONSE TABLE
September 30, 1993

Page 9 of 51

No. Page/Line No.

Comment/Response

Concurrence

8. $2-2 / 1-51$

Deficiency: The description of the demolition site does not provide adequate detail to allow potential exposure pathways to be evaluated.

Requirement: Provide description of depth to water table, soil characteristics, and any containment used during the detonation. Incorporate any available Hanford meteorological information for the times of the events. Weather conditions may have influenced the dispersion of contaminants.

RL/WHC Response 1: Information on groundwater is provided in Appendix 5A; information on the soil characteristics is located on $\mathrm{P} 2-2 / \operatorname{Ln} 10-14$

Any meteorological data that may exist would be from the Hanford Weather Station located 15 miles from HPADS. Due to this distance the weather data will not provide a one-to-one correlation of wind speed/direction at HPADS. Although no meteorological data was kept, HPADS procedures prohibited detonation activities when winds exceeded 35 miles per hour, so it is extremely unlikely that any unreacted residues were carried beyond the sampling perimeter. In the event that unreacted residues are identified beyond the closure boundaries, soil sampling and analys is may require that the closure area boundary be expanded. Note that sampling will confirm the closure boundaries, as stated on page 6-1, 1ines 20-22.

Ecology Response 1:

A. Initial sampling outside the assumed boundary of Area No. 1 has to be done (see also NOD Nos. $1(1)$ and 10 responses). 
HANFORD PATROL ACADEMY DEMOLITION SITES CLOSURE PLAN NOTICE OF DEFICIENCY RESPONSE TABLE
September 30,1993

Page 10 of 51

B. 35mph wind speed is not restrictive enough to prevent

dispersion. Refer to NOD No. 38 response for the requirements.

Ecology/RL/WHC Resolution: All parties agreed to the location and boundaries of both closure areas (Ecology/RL/WHC Resolution NOD No. 1). Meteorological data on for the demolition events is provided in Appendix $3 A$ of Rev. 1.

9. $2-2 / 17-20$ and $2-2 / 25-28$

Deficiency: "The DOE-RL also has allowed usage of the firing ranges by non-Hanford personnel . . but ended that practice in 1982." "Since 1986, . . . the Richland Police department and other personnel have used the range for firearms training." These statements appear to contradict each other.

Requirement: Revise the text to resolve the contradiction.

RL/WHC Response 1: P2-2/Ln17-20 will be revised to read "During the pre-RCRA operation of HPADS. . . allowed minimally controlled usage . . . ."

Ecology Response 1: Response is not clear. Needs to be clarified by RL/WHC.

Ecology/RL/WHC Resolution: Text will be revised to read, "The DOE-RL allowed minimally controlled usage of the firing ranges by non-Hanford personnel (e.g., the city of Richland Police

Department and the Richland Rod and Gun CTub), but ended that practice in 1982. After 1982, the DOE-RL began supervising usage of the firing ranges by non-Hanford personne1."

10. $2-2 / 46-50$

Deficiency: The plan states that the firing range containing Closure Area No. 1 has been repeatedly graded. Because of the 
HANFORD PATROL ACADEMY DEMOLITION SITES CLOSURE PLAN NOTICE OF DEFICIENCY RESPONSE TABLE
September 30, 1993

Page 11 of 51

grading, the entire firing range should be sampled to identify soil that may have been contaminated by the detonations.

Requirement: Revise the plan to increase the area to be sampled.

RL/WHC Response 1: Expansion of the detonation area due to soit dispersion during grading may have occurred but would not be significant when compared, to the size of the closure area boundaries. These boundaries were established by personnel that were present during the detonation events and will be confirmed by the sample results.

Ecology Response 1: Nothing outside the boundary will be confirmed without sampling outside the boundary (see requirement of the NOD No. 1 (1) response). Since regrading Area No. 1 could very possibly redistribute the surface layer of the contaminated soil in an non-negligible extent, in addition, there were no hard evidences other than personnel memory to locate the actual position for Area No. 1, initial sampling has to be done outside the assumed boundary of Area No. 1 .

\section{Ecology/RL/WHC Resolution: See Ecology/RL/WHC Resolution response} to NOD No. $1(1)$.

11. $2-3 / 17-22$

Requirement: Determine if this paragraph is still accurate with the recent security downgrades.

RL/WHC Response 1: Section 2.4 will be revised, 1 ines 8 to 22 will be deleted, and the remaining sentences will be incorporated into one paragraph.

Ecology Response 1: Concur with the revisions. 
HANFORD PATROL ACADEMY DEMOLITION SITES CLOSURE PLAN NOTICE OF DEFICIENCY RESPONSE TABLE
September 30,1993

Page 12 of 51
No. Page/Line No.

12. $3-1 / 10$

13. $3-1 / 14-16$
Comment/Response

Concurrence
Deficiency: This description does not agree with Page 1-1, 1ines 12-13, which state that these demolition events were "a form of thermal treatment for spent or abandoned chemical waste."

Requirement: Revise the text to resolve the contradiction and define discarded explosive chemicals more clearly.

RL/WHC Response 1: No spent chemicals were treated at HPADS. The word 'spent' will be removed from page 1-1/ 1 ines 12 to 13 for consistency with the Chapter 3.0 usage of 'discarded chemicals'.

Ecology Response 1: The discarded chemicals have to be waste explosives, because, under 40 CFR 265.382, open burning of hazardous waste (except for detonation of waste explosives) is prohibited (see also NOD No. 6).

\section{Ecology/RL/WHC Resolution: See Ecology/RL/WHC Resolution to} NOD No. 6.

Deficiency: This paragraph implies that the detonations took place at multiple locations. Thus, the boundary of Closure Area 1 should be entarged.

Requirement: Revise the plan as necessary. See also comment 10 .

RL/WHC Response 1: Page 2-2/Ln46-47 states that sampling will occur on both sides of the boundary wall to "confirm" the boundary. Refer to NOD Nos. $1 A$ and 37 comment responses.

Ecology Response 1: See NOD Nos. 1 (1) and 37 responses.

Ecology/RL/WHC Resolution: See resolution to NOD No. 1(1) and 37 . 
HANFORD PATROL ACADEMY DEMOLITION SITES CLOSURE PLAN NOTICE OF DEFICIENCY RESPONSE TABLE
September 30, 1993

Page 13 of 51

No. Page/Line No.

Comment/Response

Concurrence

14. $3-1 / 27-32$

Requirement: The explosives used to initiate the detonation (and any regulated products potentially generated from the detonation) must be incorporated into the sampling and analysis plan.

RL/WHC Response 1: WAC 173-303-610 requires that dangerous waste and dangerous waste constituents managed at the facility be addressed at closure. The HPADS Closure Areas are completely within the Hanford Patrol Academy Firing Ranges; which since the 1950s, and until Hanford is closed, serve as the firearms training area for the Hanford Security Forces, and with RL permission other police agencies. Therefore, the lead within the HPADS Closure Areas will be handled in coordination with the final Hanford Patrol Academy remedial action. RL/WHC believe that any lead bullet fragments and residues from explosives used to initiate the detonations are not distinguishable from the firearm's training bullets and other materials that were used at the firing ranges.

Ecology Response 1: List the types of explosives used in the detonations. If the explosives are the same as those used in the firearm's training, the responses will be considered enough. otherwise, please answer the question.

Ecology/RL/WHC Resolution: The DQ0 participants agreed that EPA Method 8330, Explosives Residues by HPLC, would be an indicator of elevated levels of unreacted detonation cord residues. EPA Method 8330 will be performed per the SAP.

15. $3-2 / 30-38$

Deficiency: This paragraph describes a demotition failure and a grass fire ignited by a detonation, but does not state when they occurred. 
HANFORD PATROL ACADEMY DEMOLITION SITES CLOSURE PLAN NOTICE OF DEFICIENCY RESPONSE TABLE
September 30, 1993

Page 14 of 51

Requirement: Revise the plan to answer the following questions: When did the incidents described in this paragraph take place? Was it before or after 1984? After other detonations, how were the remains of the containers managed? Were the containers, or pieces of containers, removed from the site? If so, how were they managed?

RL/WHC Response 1: The incomplete detonation occurred on March 12, 1987. Al1 containers except one metal can of ether (one pint) were destroyed. The ethyl ether container ruptured from the explosion and was burned. The following morning the contaminated soil was placed in 30 gallon drums. The drums were later shipped to an off-site treatment storage and disposal facility.

The grass fire occurred on 0ctober 30, 1985. At that time, dry nuisance grasses were surrounding the detonation pit. This information will be incorporated in the closure plan.

Ecology Response 1: Wind conditions may have influenced the incidents. Provide meteorological data.

Ecology/HHC/RL Resolution: Biased sample locations were agreed to during the DQO negotiations and are documented in the SAP. Meteorological data will be provided in the next revision.

16. $4-1 / 10-11$

Requirement: Provide the best estimate of the amount of material detonated before 1984. Clearly state the limitations of the data.

RL/WHC Response 1: Prior to 1984 no accurate records of the detonation events were kept.

Ecology Response 1: See NOD Nos. 1 (2) and 37 responses. 
HANFORD PATROL ACADEMY DEMOLITION SITES CLOSURE PLAN NOTICE OF DEFICIENCY RESPONSE TABLE
September 30, 1993

Page 15 of 51

No. Page/Line No.

Comment/Response

Concurrence

Ecology/RL/WHC Resolution: During the DQO negotiations, all parties agreed that no estimates of the amount of material detonated could be quantified, and that the physical properties of the pre-1984 inventory should not be significantly different from the post-1984 inventory (e.g., only explosive, highly reactive shock sensitive materials were treated in what is now Closure Area No. 1).

17. $4-1 / 31-35$

Deficiency: Table 4-3, referred to here, is not included in the closure plan:

Requirement: Revise the plan by including the table or removing the reference.

RL/WHC Response 1: See response to 1C.

Ecology Response 1: Refer to NOD No. 1(3) response.

Ecology/RL/WHC Resolution: Table 4-3, Physical Properties of the Chemicals Treated at the HPADS, will be included in Rev. 1.

18. $6-1 / 20-22$

Deficiency: "The final closure area boundaries will be confirmed by the results of regulatory acceptable soil sampling and analyses." According to Page 7-6, Tines 33-35, no samples are to be taken outside the boundaries of Closure Area 1 . How will the boundaries be confirmed without taking samples outside the boundary?

Requirement: The boundary must be determined by sampling and analyzing for indicator parameters. See comment 37.

RL/WHC Response 1: Refer to NOD Nos. 1A and 37 comment responses. 
HANFORD PATROL ACADEMY DEMOLITION SITES CLOSURE PLAN NOTICE OF DEFICIENCY RESPONSE TABLE
September 30, 1993

Page 16 of 51

Deficiency: The term "regulatory acceptable" is open to interpretation.

Requirement: Please replace with more specific wording.

$\mathrm{RL} /$ WHC Response 1: This section will be revised to read, ". . by the results of a pre-approved sampling and analysis plan."

Ecology Response 1: See NOD Nos. 1 (1) and 37 responses for the first part of the question. Concur with the correction to the second part of the question.

\section{Ecology/RL/WHC Resolution: The boundary locations were agreed on} at the DQO negotiations and are documented in the SAP.

19. $6-1 / 33-37$

Requirement: The closure plan should state that the metal posts marking Closure Area 1 are removed for safety when the firing range is in use.

RL/WHC Response 1: The metal posts were removed/replaced as a procedural step during firing events. When the posts are removed their location is marked with wood stakes placed in the ground. Upon completion of firing activities, the stakes are removed and the metal posts are driven by hand into the ground. These steps are performed as part of procedure and does not affect on the closure plan or boundaries.

Ecology Response 1: The demolition sites may have been contaminated already by hazardous wastes. Therefore, non TSD personnel should not have access at any time, including during the firing activities. 
HANFORD PATROL ACADEMY DEMOLITION SITES CLOSURE PLAN NOTICE OF DEFICIENCY RESPONSE TABLE
September 30, 1993

Page 17 of 51

№. Page/Line No.

Comment/Response

Concurrence

Ecology/RL/WHC Resolution: At the DQO negotiations, all parties agreed that any unreacted residues would have remained within the boundaries of Closure Area No. 1. All parties also agreed that the Hanford Patrol Academy would remain in operation until it was no longer needed for training purposes.

20. $6-1 / 38-39$

Deficiency: The maximum soil depth of three feet for sampling is insufficient. Undetonated materials can be driven to considerable depths.

Requirement: The depth should be determined by sampling and analyzing for indicator parameters.

RL/WHC Response 1: Downward continuity of contamination will be evaluated as the sampling results indicate; i.e., contamination will be defined as necessary in all three primary directions. Refer to NOD No. 38 comment response.

Ecology Response 1: See NOD No. 38 response.

Ecology/RL/WHC Resolution: Through the DQO negotiations, all parties agreed that samples would be collected in two distinct depth strata, at 0 to 6 inches and 12 to 18 inches below the surface, as is documented in the SAP.

21. $6-1 / 42$

Deficiency: " . . a series of field screening surveys might be performed." This is not sufficient detail.

Requirement: Explain how the decision will be made to perform field screening surveys, when the decision will be made, and how the screening methods will be chosen. Also provide the methods 
HANFORD PATROL. ACADEMY DEMOLITION SITES CLOSURE PLAN NOTICE OF DEFICIENCY RESPONSE TABLE
September 30, 1993 Page 18 of 51

that will be used, the capabilities of the instruments to be used, and Data Quality Objectives.

RL/WHC Response 1: Field screening methods may be applied in supplemental sampling to determine the extent of soil contamination. The need for supplemental sampling will be evaluated based on the results of initial sampling (described in Section 7.2). The decision to do field screening will not be made until initial sampling results have been compiled and reviewed with Ecology. The utility of various field screening instruments and methods will be considered based on their capabilities to identify specific contaminants of concern at appropriate detection levels (see al so NOD No. 48 comment response). Proposed disposition for this comment is to delete the fifth paragraph on page 6-1, from line 41 to Tine 44 .

Ecology Response 1: Concur.

Ecology/RL/WHC Resolution: A11 parties at the DQO negotiations agreed that field screening wi1l not be performed and that the samples will be analyzed at an offsite EPA-approved level III laboratory.

22. $6-2 / 4-5$

Deficiency: The plan states that background will be Site-wide background threshold values as defined in the Hanford Site Soil Background (DOE/RL 1992d). At present, this study is not complete and Ecology has not yet received final data packages for constituents of concern.

Requirement: Ecology must review and approve the Hanford Site Soil Background (DOE/RL 1992d) before the values can be implemented for closure. 
HANFORD PATROL ACADEMY DEMOLITION SITES CLOSURE PLAN NOTICE OF DEFICIENCY RESPONSE TABLE
September 30, 1993

Page 19 of 51

RL/WHC Response 1: The Hanford Site Soil Background (DOE/RL 1992d) was issued for Ecology review May 14, 1993.

Ecology Response 1: Ecology did receive The Hanford Site Soil Background. However, the document was considered incomplete. There is still a huge task ahead in order to finish the site-wide background analysis (see detail in the memo from Charles Cline, WA State Department of Ecology, to Steven Wisness, US DOE, dated at May 10, 1993).

Requirement: Ecology must review and approve the Hanford Site Soil Background (DOE/RL 1992d) before the values can be implemented for closure.

Ecology/RL/WHC Resolution: Ecology/RL/WHC Resolution: Through the DQO process, all parties have agreed to use Hanford Site Soil Background levels as one of the criteria for action levels. Also, the Hanford Soil Background is listed as a closure performance standard in the Hanford Facility RCRA Permit, Section II.K.2.

23. $6-2 / 11-12$

Deficiency: This paragraph discusses the proposed method to determine cleanup levels. It is said that the health-based levels will be based on equations and exposure assumptions presented in the Hanford Site Baseline Risk Assessment Methodology (DOE/RL 1992B). This is not appropriate.

Requirement: Health-based levels, if permitted for closure, are determined from the Model Toxic Control Act (MTCA). 
HANFORD PATROL ACADEMY DEMOLITION SITES CLOSURE PLAN NOTICE OF DEFICIENCY RESPONSE TABLE
September 30,1993

Page 20 of 51

RL/WHC Response 1: HSBRAM is the onsite procedure, approved by Ecology, that implements MTCA. Copies of HSBRAM have been supplied to Ecology.

Ecology Response 1: HSBRAM is not approved to implement MTCA by Ecology. Instead, only some of the risk assessment requirements of the MTCA Cleanup Regulation was incorporated in HSBRAM by US DOE (see detail in the Memo from US DOE to George Hofer, US EPA, and Roger Stanley, WA Department of Ecology, dated at May 5, 1993).

Requirement: Health-based levels, if permitted for closure, are determined from the Model Toxic Control Act (MTCA).

Ecology/RL/WHC Resolution: Through the DQO process, action levels were defined, and agreed to by all parties, as levels above the Hanford Site soil background levels identified in Hanford Site Background: Part 1, So 71 Background for Nonradioactive Analytes (DOE-RL 1993) and MTCA (WAC 173-340) Method B levels.

24. $6-3 / 25-26$

Requirement: Strike "and implemented by the Hanford Site Baseline Risk Assessment Methodology (DOE-RL 1992C)." See comment number 23.

RL/WHC Response 1: See comment No. 23 response.

Ecology Response 1: See NOD No. 23 response.

Ecology/RL/WHC Resolution: See resolution to NOD No. 23. 
HANFORD PATROL ACADEMY DEMOLITION SITES CLOSURE PLAN NOTICE OF DEFICIENCY RESPONSE TABLE
September 30, 1993

Page 21 of 51

No. Page/Line No. Comment/Response

Concurrence

25. $6-4 / 26-41$

Deficiency: There is no way to determine if contamination is from HPADS activities or other sources, therefore all contamination at the site must be addressed.

Requirement: Revise the plan to address all contamination.

Note: You may wish to consider remediating the entire site under RCRA rather than deferring to CERCLA since the same waste types are present.

RL/WHC Response No. 1: Table 4-1 provides a summary of the dangerous wastes treated at the HPADS. Sample analysis indicating contamination other than the wastes managed at the HPADS will be remediated in coordination with CERCLA activities as explained on page $6-4$, lines $34-40$.

Continuous use of the Hanford Patrol Academy is necessary to maintain overall Hanford site security.

Ecology Response 1: See NOD No. 1 (2) response.

Ecology/RL/WHC Resolution: See NOD No. 1 (2) response.

26. $6-4 / 38-40$

Deficiency: This sentence should state, "if the soil is contaminated only from sources other than HPADS activities."

Requirement: Revise the text.

RL/WHC Response 1: The text will be revised with the following deletions: ". . in addition to HPADS activities... "from Tine 35 and Tines $38-40$. With these deletions this section states that 
HANFORD PATROL ACADEMY DEMOLITION SITES CLOSURE PLAN NOTICE OF DEFICIENCY RESPONSE TABLE
September 30, 1993

Page 22 of 51

contamination from HPADS will be addressed under RCRA, and contamination from other sources will be coordinated with CERCLA.

\section{Ecology Response 1: See NOD No. 1 (2) response.}

Ecology/RL/WHC Resolution: See NOD No. 1 (2) response.

27. F6-1

Deficiency: This flowchart shows actions based on whether the contaminants found are RCRA or CERCLA. I understand that CERCLA contaminants expected at the site include those from wastes detonated before 1984. Also, samples are to be analyzed only for RCRA waste constituents. In that case, you cannot identify contaminants as RCRA or CERCLA.

Requirement: Revise to agree with revised $p 1$ an.

RL/WHC Response 1: The flowchart will not be revised. If a contaminant from the waste inventory is detected above the action level, it will be addressed by RCRA, regardless of its regulatory status.

\section{Ecology Response 1:}

A. Refer action level to NOD No. 1(3) response.

B. RL/WHC Response 1 was not based on the flowchart.

C. The definition of CERCLA/RCRA integration in flow chart (F6-1) was vague. Refer to NOD No. 1(2) response. 
HANFORD PATROL ACADEMY DEMOLITION SITES CLOSURE PLAN NOTICE OF DEFICIENCY RESPONSE TABLE
September 30, 1993

Page 23 of 51

28. $7-1 / 18-45$

\section{Ecology/RL/EPA Resolution: Figure $6-1$ will be revised to address} RCRA/RPP integration. Refer to NOD 1(3) for resolution on action levels and 1(2) for resolution on RCRA/RPP.

Deficiency: The text described possible existence of a canister of napalm B buried in either of the HPADS areas, and proposed a ground-penetrating radar (GPR) survey. The size of the canister is important in setting up the grid for a GPR survey. Nowhere in the text was the size of the object mentioned. A canister of very small size (eg., one or two feet length) would be difficult to detect at a five foot grid interval. Has an electromagnetic induction (EMI) survey been considered? Both GPR and EMI surveys show good results in identifying shallow buried metallic objects.

Requirement: Discuss the reasons for choosing a GPR survey in the closure plain.

$\mathrm{RL} /$ WHC Response 1: The canister is identified in text as containing $5 \mathrm{lb}$. of napalm B compound.

Assuming a unit weight of $501 \mathrm{bs} / \mathrm{ft}^{3}$, the container could be as small as $1 \mathrm{pt}$ or $1 \mathrm{qt}$. Theoretically, either GPR or EMI could be used to locate a buried metal container of this size. With EMI, the WHC geophysics staff was pessimistic that a 1-qt container could be clearly distinguished from other objects such as a 50-cal bullet (i.e., there was concern that EMI would produce more false positives). Upon further review of the text, and with the benefit of recent field experience with these survey techniques, the WHC geophysics staff agrees that a smaller (say 1-meter) grid would be more appropriate. Text will be revised to reflect this assessment. 
HANFORD PATROL ACADEMY DEMOLITION SITES CLOSURE PLAN NOTICE OF DEFICIENCY RESPONSE TABLE
September 30, 1993

Page 24 of 51

Ecology Response 1: Concur with revision.

Ecology/RL/WHC Resolution: On September 26, 1994, a preliminary GPR survey was performed. Because of the copious presence of foreign debris (e.g., bullets, spent cartridges, and rocks, and the anomalous radar signatures they generate during the survey), GPR personnel determined that the presence or absence of the canister could not be ascertained. At this time, no future GPR activities are anticipated by RL/WHC. The text will be revised accordingly.

29. $7-2 / 1-2$

Question: If the mobile laboratory is not available, what will be the effect on the schedule? Will the closure still be completed in 180 days? Note that the mobile laboratory can only be used for indicator sampling to determine areas of contamination. See comment 2 .

Requirement: The name of the laboratory that will be conducting the analyses must be submitted to Ecology before closure begins.

RL/WHC Response 1: If the mobile laboratory is not available to support sampling at the HPADS closure areas, then sample analys is would have to be performed by an offsite contractor laboratory.

The following schedule forecast would apply in that event:

- Sampling: 1 week (no change)

- Offsite analysis: 12 weeks ( 9 weeks longer than shown for ML)

- Data Evaluation: 12 weeks (no change) 
Offsite analysis would add 9 weeks to the initial (investigative) phase of soil sampling. Because the ML is now offering Analytical Level II services, rather than Level III, an additional round of confirmatory sampling will be required. The breakdown for offsite analysis (1 isted above) will increase the schedule in Figure 7-3 by 25 weeks. Closure in 180 days is infeasible.

Ecology Response 1: The increase of 25 weeks is not acceptable according to TPA. In TPA 9.6.2, it is stated that non-rad waste analyses have a maximum turnaround time of 50 days. Also, in TPA 9.6, the maximum validation and transfer times are 21 and 15 days, respectively. Thus, the maximum per Sample Delivery Group (SDG) should be 86 days. Revise the text accordingly.

Ecology/RL/WHC Resolution: The mobile laboratory will not be used for these clean closure activities. Throughout the closure plan, references to using the mobile laboratory will be removed. offsite laboratories capable of EPA analytical level III will be used for all soil samples. Offsite laboratories should follow the negotiated laboratory schedule listed in the Tri-Party Agreement.

30. $7-3 / 15-17$

Deficiency: Microbial activity in this area is not very efficient. The sentence should read, "Unreacted volatiles and semivolatiles contaminant levels might have been reduced via microbial activity." It is unlikely that they would have been el iminated.

Requirement: Revise the text.

RL/WHC Response 1: Text will be revised to read, ". . . reduced via microbial activity and exposure to the desert environment." 
HANFORD PATROL ACADEMY DEMOLITION SITES CLOSURE PLAN NOTICE OF DEFICIENCY RESPONSE TABLE
September 30, 1993

Page 26 of 51
No. Page/Line No.

31. $7-3 / 37-48$

32. $7-3 / 44-48$
Comment/Response

Concurrence

Ecology Response 1: Concur with the revision.

Deficiency: This paragraph states, "It is generally acknowledged that detonation and thermal destruction are very efficient processes, and that any dangerous waste constituents that might remain in the soil at either closure area probably would exist at very low concentrations..." A reference should be provided for this statement.

Requirement: Revise the text.

RL/WHC Response 1: Sentence will be revised to read "It is believed that detonation and thermal destruction are relatively efficient processes, and that any dangerous waste constituents that might remain in the soil at either closure area are likely to exist at very low concentrations, such that detection might be difficult." (Additional clarification to be provided by Ecology as appropriate.)

Ecology Response 1: Concur with the revision.

Deficiency: Portable field screening instruments are considered level I, not level I and II.

Requirement: Revise the text.

Response: The text will be revised.

Ecology Response 1: Concur with the revision. 
HANFORD PATROL ACADEMY DEMOLITION SITES CLOSURE PLAN NOTICE OF DEFICIENCY RESPONSE TABLE
September 30, 1993

Page 27 of 51

No. Page/Line No.

Comment/Response

Concurrence

Ecology/RL/WHC Resolution: Field screening will not be performed. All samples will be analyzed at an offsite level III laboratory per the DQO negotiations.

33. $7-3 / 21$

Requirement: Define "action levels" for each constituent. The action levels must be approved by Ecology before closure begins. See comment.

RL/WHC Response 1: Action levels are defined on page 6-2, line 1-9.

Response: Action levels will be provided.

Ecology Response 1: Refer action level to NOD No. 1 (3) response.

Ecology/RL/WHC Resolution: Through the DQO process, all parties agreed that to meet criteria for clean closure of the HPADS, the soil sampling and analytical results must verify that the levels of discarded explosive chemical products derived from the HPADS operations are below action levels. Agreed action levels are defined as levels above the Hanford Site soil background levels identified in Hanford Site Background: Part 1, Soil Background for Nonradioactive Analytes and MTCA Method B levels.

34. $7-5 / 9-11$

Deficiency: Benzoyl Peroxide is not unstable in the presence of moisture; it will explode when in the environment of $<1 \%$ water, and it should be mixed in an environment of at least $33 \%$ water (Hawleys Condensed Chemical Dictionary, Sax and Lewis, 1987 , p. 134).

Requirement: Revise the text. 
HANFORD PATROL ACADEMY DEMOLITION SITES CLOSURE PLAN NOTICE OF DEFICIENCY RESPONSE TABLE
September 30, 1993

Page 28 of 51

RL/WHC Response 1: Text wi11 be revised to read as follows:

"Butyllithium is unstable in the presence of moisture or moist air (e.g., soil moisture originating as dew or precipitation) (Sax and Lewis 1987, p. 188; A7drich 1986, p. 251). Benzoyl peroxide is unstable under conditions of reduced moisture (i.e., $<1 \%$ )

(Sax and Lewis 1987, p. 134); soil moisture conditions under $1 \%$ are common at the Hanford Site during the summer months of the year."

\section{Ecology Response 1: Concur with the revision.}

Ecology/RL/WHC Resolution: This section will be deleted from the next revision of the closure plan because it dealt with using the onsite mobile laboratory. All samples will be analyzed at an offsite level III laboratory per the DQO negotiations.

35. $7-5 / 41-42$

Deficiency: Nitrate $\left(\mathrm{NO}_{3}{ }^{-}\right)$is not "environmentally benign" at or above regulatory limits. The decomposition products 7 isted should also be verified.

Requirement: Revise the text.

RL/WHC Response 1: Accept. Will insert " . . . in trace quantities" at the end of iine 43. (Additional clarification to be provided by Ecology as appropriate.)

Ecology Response 1: Concur with the answer to the first part of the question. Second part of the question remains to be answered.

Ecology/RL/WHC Resolution: The SAP documents the agreed on analyses for chemical inventory and degradation products. This section will be deleted from Rev. I of the closure plan 
HANFORD PATROL ACADEMY DEMOLITION SITES CLOSURE PLAN NOTICE OF DEFICIENCY RESPONSE TABLE
September 30, 1993

Page 29 of 51
No. Page/Line No.

36. $7-6 / 26-29$

37. $7-6 / 33-35$
Comment/Response

Concurrence

because a11. samples will be analyzed at an offsite level III laboratory.

Requirement: Add a provision to sample any visibly contaminated areas in addition to grid sampling.

RL/WHC Response 1: There are no visibly contaminated areas. As discussed in Section 3.0, the sites were inspected immediately after demolition events, and any visibly contaminated areas were cleaned up. Specific instances where cleanups were performed are noted in paragraph 4, page 3-2.

Ecology Response 1: Concur. See also NOD No. 15 response.

Deficiency: The sample locations given are all within the established boundaries of Closure Area 1. Page 6-1, 1ines 20-22, states that the boundaries may be adjusted based on the sampling results. How could the boundaries be adjusted if no samples are taken outside the boundaries?

Requirement: Samples must be taken outside the expected boundaries to determine the actual location of the boundaries. See also comment 10.

RL/HHC Response 1: As indicated in Chapter 4.0 and Table 4-1, a number of small (e.g., 1 pint or 1 quart) containers were detonated at Closure Area No. 1 on one occasion in 1984. The containers were either initiated by rifle fire (i.e., detonated individually) or placed together in a shallow, hand-excavated pit and detonated en masse. The closure area boundaries are believed to be sufficiently large in this case to include any/all potential soil contamination from the 1984 demolition event. The principal 
HANFORD PATROL ACADEMY DEMOLITION SITES CLOSURE PLAN NOTICE OF DEFICIENCY RESPONSE TABLE
September 30, 1993

Page 30 of 51

№. Page/Line No. Comment/Response

issue is one of identifying any localized residual contamination within the designated closure area. If sample results from any of the locations identified in Figure 7-1 indicate that contaminants (i.e., any of the analytes of interest in Table 7-1) are present at levels approaching proposed action levels, applicable field screening methods would be used to determine the extent of contamination (within or beyond the current boundary).

Ecology Response 1:

A. Refer action Tevel to NOD No. 1(3) response.

B. Note: Field screening instruments usually do not have the required detection levels to verify an area of contamination, and it is only indicative.

Requirement: The possible contaminations from the detonations before 1984 should also be sampled. Because of no hard evidences on the boundary of Area No. 1 and the regradation, initial sampling outside the so-called boundary has to be done for Area No. 1 (see also NOD Nos. $1(1)$ and 1(2) responses).

Ecology/RL/WHC Resolution: See resolution to NOD No. 1(1), (2), and (3).

38. $7-7 / 20-38$

Deficiency: At each sampling location, sampling and analys is for organics should be conducted at various depths to determine the depth of contamination. Closure Area 2 is gradually filling in as a result of erosion. The $\mathrm{plan}$ does not describe how the surface elevation of the pit during the detonations will be determined. 
HANFORD PATROL ACADEMY DEMOLITION SITES CLOSURE PLAN NOTICE OF DEFICIENCY RESPONSE TABLE
September 30, 1993

Page 31 of 51

Requirement: Revise the plan to include sampling and analysis at a minimum of two feet intervals to a depth of twelve feet below the surface elevation during detonation.

RL/WHC Response 1: By nature, demolition events would have deposited reaction/combustion products (i.e., potential residual contamination) on the soil column surface (i.e., contamination inherently would be a "top down" phenomenon). Even at the point of initiation, products would not be injected or driven into the ground. The shock wave from the explosion and pressure generated by the expanding gases would cause the reaction products, container shards, and loose soil to be directed upward (the unconfined direction), not downward. It is not a reasonable expectation that contaminants could somehow be driven 12 feet into the ground as the result of the activities described in the closure plan.

Extensive research has been conducted at the Hanford Site regarding moisture evapotranspiration of soil moisture and infiltration (recharge) through the vadose zone. It has generally been determined, with some exceptions for isolated locations where the near-surface soils are extremely coarse, that wetting fronts generally do not penetrate to depths exceeding about 4 feet.

Sampling to a depth of 12 feet would require working with either a hollow-stem auger rig or a backhoe. Either option represents a major departure (in terms of time and cost) from the proposed plan. To attempt to resolve this issue, WHC would propose to sample to a depth of 4 feet at the open circled locations shown in Figures $7-1$ and $7-2$ in the plan. WHC also would be willing to offer to resample at extended depths at any location where initial sampling results indicate that contaminants are present at or close to proposed action levels. 
Concerning the elevation of the invert of the pit at the time of the most recent demolition event: it may not be feasible to provide this information with any degree of certainty. No effort was made to record or identify the invert surface datum while the site was in use, and there may be no surviving tangible evidence that would enable WHC to accurately identify the elevation at this time.

Fcology Response 1: The closure should be processed to achieve the performance standard of WAC 173-303-610(2) rather than be restricted by any proposed plan. Adjusting sampling depth according to the initial sampling results is considered acceptable. However, initial biased sampling to 12 feet was required at 1east $30 \%$ of the proposed sampling locations. It has to include the two sampling locations near the geometric center of the site. Otherwise, experimental and/or theoretical demonstrations must be furnished to show that the penetration depth of the waste explosives and byproducts from the detonation process and following precipitations are less than 12 feet under the specific geological conditions of the detonation sites.

A biased sampling in the down-wind direction will also be required unless experimental and/or theoretical demonstrations can be furnished to show that the migration distance of the waste explosives and the byproducts is negligible assuming that the wind speed is less than, and/or equal to, $35 \mathrm{mph}$.

For Area No. 2, the beginning depth of sample should be the invert of the demolition pit not the current surface. If no way exists to determine the position of the invert, it should be deep enough to exclude any refill after the last detonation. 
HANFORD PATROL ACADEMY DEMOLITION SITES CLOSURE PLAN NOTICE OF DEFICIENCY RESPONSE TABLE
September 30, 1993

Page 33 of 51

No. Page/Line No.

Ecology/RL/WHC Response: The SAP documents the sampling agreements.

39. $7-8 / 8-12$

Requirement: Explain why the adequacy of currently available background data cannot be evaluated now.

RL/WHC Response 1: When Section 7.0 of the closure plan draft was prepared, the list of analytes to be reported in the Hanford Site Soil Background report (DOE/RL 1992d) had not been finalized. However, it was recognized at an early stage of work on the plan that the majority of the analytes of interest would be organics. As stated on page 7-7, line 50 continuing to page 7-8, line 2, background values for organic analytes will be assumed to be negligibly small (i.e., essentially zero). The adequacy of background data for inorganics depends on the type of analyte(s) involved and the analytical method(s) used for quantitation. For example, Hanford Site Soil Background information for metals would not be usable as a basis for comparison because the background data were obtained by ICP and AA methods, whereas the proposed Environmental Analytical Laboratory will be analyzing metals by XRF. The only currently identified inorganic analyte of interest for HPADS is chloride (Table 7-2). Analysis by IC is proposed. A threshold value for chloride (determined by IC) is available in the Hanford Site Soil Background document. Section 7.2.3.2 will be updated in Revision 1 to reflect the current status.

Ecology Response 1:

A. For inorganic analyses, Level III (ICP/AA) should be used, thus data will be comparable to Hanford Site Soil Background.

B. Anatysis by IC is acceptable as level II for analytical support; however, since little historical data available, do 
normal ICP/AA analyses for investigative phase. Describe also the methodology of IC more completely.

Ecology/RL/WHC Resolution: Throughout the closure plan, references to using the mobile onsite laboratory will be removed (including the use of XRF). Offsite laboratories capable of EPA analytical level III will be used for all soil samples. Through the DQO process, all sampling and analytical concerns were resolved. Constituents of concern and analytical methods were identified and agreed to by all parties. See the SAP for specific agreements.

40. $7-8 /($ a 11$)$, $7-9 /(a 11)$

41. $7-9 / 37-45$
Deficiency: Any initial characterization analyses must be performed by level III criteria, which is an EPA certified licensed, stationary laboratory. The mobile laboratory (level II analyses) should only be used to aid in determining a sampling location for characterization and plume mapping during the remediation.

Requirement: Revise the plan.

RL/WHC Response 1: See comment No. 2.

Ecology Response 1: See NOD No. 2 response.

Deficiency: X-ray fluorescence is not an approved method for metals characterization. It is only to be used as an in-field screening method to determine sampling locations or areas of contamination (plume mapping).

Requirement: Revise the plan. 


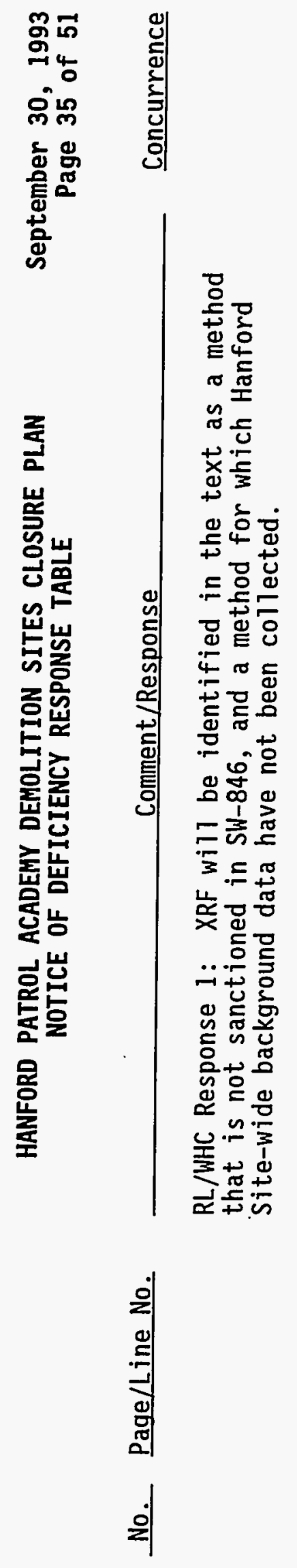


HANFORD PATROL ACADEMY DEMOLITION SITES CLOSURE PLAN NOTICE OF DEFICIENCY RESPONSE TABLE
September 30, 1993

Page 36 of 51

No. Page/Line No.

Comment/Response

Concurrence

Ecology Response 1: Concur with the revision.

Ecology/RL/WHC Resolution: Throughout the closure plan, references to using the mobile laboratory will be removed.

offsite laboratories capable of EPA analytical level III will be used for all soil samples.

42. $7-9 / 47-51$

Requirement: Detection limits for the constituents listed must be below the regulatory limits, when possible. If regulatory limits are below detection limits, the method with the lowest detection limit must be used.

RL/WHC Response 1: Statements will be inserted at the beginning of Section 7.2.4 advising (1) that the information included in this section is general in nature and is not intended to indicate or specify analytes of interests for HPADS closure areas Nos. 1 and 2 and (2) the proposed analytes for the two HPADS closure areas are listed in Tables 7-1 and 7-2. (Clarification to be provided by Ecology.)

Ecology Response 1: Any analytical work at level II should have detection limits close or below regulated limits - response does not discuss how detection limits were chosen (criteria) here.

Ecology/RL/WHC Resolution: Throughout the closure plan, references to using the mobile laboratory will be removed. Offsite laboratories capable of EPA analytical level III will be used for all soil samples.

43. $7-10 / 20$

Deficiency: The capabilities of on-site mobile laboratories are not "equivalent" to analytical level III. In certain analyses, they may be similar. 
HANFORD PATROL ACADEMY DEMOLITION SITES CLOSURE PLAN NOTICE OF DEFICIENCY RESPONSE TABLE
September 30, 1993

Page 37 of 51

No. Page/Line No.

Comment/Response

Concurrence

Requirement: Revise p7an to meet WAC 173-303-110 methods.

RL/WHC Response 1: Accept. Mobile laboratory capabilities will be identified in Revision 1 as analytical Level II. Refer to NOD No. 2 comment response.

Ecology Response 1: Concur.

Ecology/RL/WHC Resolution: Throughout the closure plan, references to using the mobile laboratory will be removed. offsite laboratories capable of EPA analytical level III will be used for all soil samples.

44. $7-10 / 29-36$

Deficiency: The reasoning for doing duplicate samples is to determine the laboratory's precision. If the laboratory does the duplicate preparation, they will know which samples are the same and the reason for doing duplicate samples would be void.

Requirement: Revise the $\mathrm{plan}$ to meet $\mathrm{SW}-846$ requirements.

RL/WHC Response 1: Terminology appearing in SW-846, Chapter 1.0 (Quality Control) will be used. Separate definitions will be provided in Section 7.2.5 for duplicates (prepared in the field) and replicates (prepared in the $7 a b$ ).

Ecology Response 1: Concur with the revisions. SW-846 was not referenced in Chapter 9. Correct the error.

Ecology/RL/WHC Resolution: Throughout the closure plan, references to using the mobile laboratory will be removed. 
HANFORD PATROL ACADEMY DEMOLITION SITES CLOSURE PLAN NOTICE OF DEFICIENCY RESPONSE TABLE
September 30, 1993

Page 38 of 51

No. Page/Line No.

Comment/Response

Concurrence

Offsite laboratories capable of EPA analytical level III will be used for all soil samples.

45. $7-11 / 31-32$

Question: Is a "sample lot" the same as a "sample batch" (defined on page 7-10, lines 30-32)? If so, use consistent terminology. If not, define "sample lot."

Requirement: Use terms as defined in regulations.

RL/WHC Response 1: The intent in Rev. 0 was that the two terms are synonymous as they appeared in context. WAC 173-303-040 does not define either "sample batch" or "sample lot." SW-846 Section 1 (Quality Control) defines the term "analytical batch" for use in the intended context. "Analytical batch" will be used in place of "sample lot" and "sample batch" in the revised text.

Ecology Response 1: Concur with the revision.

Ecology/RL/HHC Resolution: Throughout the closure plan, references to using the mobile laboratory will be removed.

Offsite laboratories capable of EPA analytical level III will be used for all soil samples.

46. $7-13 / 3-29$

Deficiency: Was the initial sampling plan statistically designed? The sampling plan must be evaluated by a statistician prior to any work, to determine if the sampling and analyses are adequate to answer the information listed in this section.

Requirement: Refer to Ecology statistical guidance.

RL/WHC Response 1: The draft plan was reviewed by a qualified statistician. RL/WHC does not use Ecology's statistical guidance 
HANFORD PATROL ACADEMY DEMOLITION SITES CLOSURE PLAN NOTICE OF DEFICIENCY RESPONSE TABLE
September 30, 1993

Page 39 of 51

package; information on statistical guidance is found in Section 7.2.8. The sample locations were determined using a random number algorithm as explained in Section 7.2.3.1. The statistical package used by WHC is equivalent to, or better than, that presented in Ecology guidance.

Ecology Response 1: Submit the statistical package used by WHC for comparison with the Ecology package.

Ecology/RL/WHC Resolution: Through the DQO process, all sampling and analytical concerns were resolved. Constituents of concern and analytical methods were identified and agreed to by all parties. See the SAP for specific agreements.

47. $7-13 / 34$

Requirement: The action levels need to be determined prior to sampling. The text should mention when action levels will be proposed and contaminant levels will be compared against proposed action plans. More information is needed on the site background threshold values. At present, the Hanford soil background study is not complete and, as far as we know, we have yet to receive the final data packages for various inorganics and organics of our concern. The study must be approved by Ecology prior to use.

RL/WHC Response 1: Regarding action levels, refer to NOD No. IC comment response. See comment No. 22 for information on site soi1 background.

Ecology Response 1: See NOD No. 1 (3) response regarding action level and NOD No. 22 for the response on site soil background.

Ecology/RL/EPA Resolution: See resolution to NOD No. 1 (3) 
HANFORD PATROL ACADEMY DEMOLITION SITES CLOSURE PLAN NOTICE OF DEFICIENCY RESPONSE TABLE
September 30, 1993

Page 40 of 51
No. Page/Line No.

48. $7-14 / 16-30$

49. $7-14 / 35$

Deficiency: The random sampling method for the calculation of volume of contaminated soil is not acceptable. Although the determination of sampling locations by using random algorithm for initial characterization as specified in section 7.2 .3 is acceptable, the location of sampling point for calculation of the volume of contaminated soil demands a systematic protocol. Sampling plans with well defined grid patterns will be a good approach for this. However, the grid spacing, location, etc. might vary depending on the results obtained in the initial characterization. The grid spacing, location, etc., must be approved by Ecology before it is implemented.

Requirement: Submit a sampling protocol to Ecology for approval before sampling.

RL/WHC Response 1: A sampling protocol will be provided in the closure plan for Ecology approval.

Ecology Response 1: Include the sampling protocol in next revision for Ecology's approval.

Ecology/RL/WHC Resolution: Through the DQO process, all sampling and analytical concerns were resolved. Constituents of concern and analytical methods were identified and agreed to by all parties. See the SAP for specific agreements.

Deficiency: Two feet vertical depth is not sufficient.

Requirement: Revise the text. See comment 38.

RL/WHC Response 1: Refer to NOD No. 38 comment response. 
HANFORD PATROL ACADEMY DEMOLITION SITES CLOSURE PLAN NOTICE OF DEFICIENCY RESPONSE TABLE

September 30, 1993

Page 41 of 51

No. Page/Line No.

Comment/Response

Concurrence

Ecology Response 1: See NOD No. 38 response.

Ecology/RL/WHC Resolution: See resolution to NOD No. 38 .

50. $7-15 / 17-22$

Deficiency: The application of water during removal to control dust needs careful examination and will depend on the contaminants of concern. There is a good chance that contaminants can migrate with water downward during the process. This is especially so since excavation is limited to the top two feet of the material. other dust control devices may have to be applied depending on the nature of the contaminants. Also, creating a damp condition of the soil before excavation is risky.

Requirement: Determine the detailed process after we receive all the information on contaminants of concern. Submit to Ecology for approval before implementation.

RL/WHC Response 1: This information will be provided to Ecology before implementation.

Ecology Response 1: Concur.

51. $7-16 / 13-26$

Deficiency: Regulatory requirements require that verification sample analyses be done at level III or IV. A mobile laboratory does not qualify. Verification analyses must be done in accordance with SW-846.

Requirement: Revise the text.

RL/WHC Response 1: Refer to NOD No. 2 comment response.

Ecology Response 1: Concur with the revision. 
HANFORD PATROL ACADEMY DEMOLITION SITES CLOSURE PLAN NOTICE OF DEFICIENCY RESPONSE TABLE
September 30,1993

Page 42 of 51

№. Page/Line No. Comment/Response

Ecology/RL/WHC Resolution: Throughout the closure plan, references to using the mobile onsite laboratory will be removed. offsite laboratories capable of EPA analytical level III will be used for all soil samples.

52. F7-1 and F7-2 Requirement: The map legend should explain what the black dots with a circle surrounding it means.

RL/WHC Response 1: The legend will be clarified.

Ecology Response 1: Concur.

Ecology/RL/WHC Resolution: Figures 7-1 and 7-2 will be removed from Rev. 1. Refer to the SAP for sample locations.

53. F7-1 and F7-2 Deficiency: Sampling locations do not cover any areas in the downwind direction.

Requirement: Sampling must be done to characterize all areas that could possibly be contaminated. See comment 18 .

RL/WHC Response 1: See response to comments 8 and 10 .

Ecology Response 1: See NOD Nos. 8 and 10 responses.

Ecology/RL/WHC Resolution: Through the DQO process, all sampling and analytical concerns were resolved. Constituents of concern and analytical methods were identified and agreed to by all parties. See the SAP for specific agreements.

54. $F 7-2$

Requirement: Show location of demolition pit on grid. 
HANFORD PATROL ACADEMY DEMOLITION SITES CLOSURE PLAN NOTICE OF DEFICIENCY RESPONSE TABLE
September 30, 1993

Page 43 of 51

No. Page/Line No. Comment/Response

RL/WHC Response 1: The grid will be revised to incorporate the demolition pit.

Ecology Response 1: Concur with the revision.

Ecology/RL/WHC Resolution: Figures 7-1 and 7-2 will be deleted from Rev. 1. See the SAP for specific agreements regarding sample location.

55. F7-3

This closure schedule does not allow for soil removal or show the times the firing range will be out of use.

Requirement: Show on the schedule the times the firing range will be out of use. Provide an estimate of the additional time needed if soil removal is necessary.

RL/WHC Response 1: RL/WHC believes that HPADS will be clean closed so soil removal is not necessary. In the event contamination is detected, the amount of contaminated soil will be determined based on soil sampling results and the constituent specific action levels and cannot be calculated prior to the soit sampling program.

Ecology Response 1: Clean closure doesn't mean that the site is clean. To achieve clean closure, the contaminated materials should either be removed from the sites or decontaminated. It is irrational to assume that clean closure will be achieved due to no contaminations, even before sampling. Therefore, provide a time schedule in the next revision for a probable event of soil removing and decontamination. 
HANFORD PATROL ACADEMY DEMOLITION SITES CLOSURE PLAN NOTICE OF DEFICIENCY RESPONSE TABLE
September 30,1993

Page 44 of 51

No. Page/Line No.

Comment/Response

Concurrence

Ecology/RL/WHC Resolution: As a result of the DQO negotiations, all parties agreed to a two-phased sampling approach. During phase I sampling, the samples should verify the RL/WHC belief that clean closure can occur without any further remedial action. If contaminants are detected above action levels, all parties will reconvene to determine the DQO requirements. During this time frame, a soil removing and decontamination schedule will be provided.

56. $\quad F 7-4$

Deficiency: If Westinghouse Hanford Company is the "co-operator" of the site, then a representative of Westinghouse Hanford Company should sign the closure certification. See page iii, 1ines 34-44.

Requirement: Revise the figure.

RL/WHC Response 1: This comment mischaracterizes the legal nature of contractor responsibilities and would result in management inefficiencies because it attempts to inaccurately portray RL and WHC as equal partners with no distinction of responsibilities.

In Ecology's Dangerous Waste Regulations, "operator" is defined as the person responsible for the overall operation of a facility (WAC 173-303-040). WHC is not responsible for the overall operation of HPADS. The RL, Ecology, and the Environmental Protection Agency (EPA) have previously agreed in the Federal Facility Agreement and Consent Order (FFACO) that RL owns and operates the Hanford Facility. WHC has a more Timited and specific role under its contract with the RL and may not be identified as responsible for all closure activities on the HPADS. Certifying the closure $\mathrm{plan}$ as co-operator is not required by the regulations. Certifying the closure $\mathrm{plan}$ is required by the owner or operator and an independent registered professional engineer 
HANFORD PATROL ACADEMY DEMOLITION SITES CLOSURE PLAN NOTICE OF DEFICIENCY RESPONSE TABLE
September 30, 1993

Page 45 of 51

(WAC 173-303-610). RL is the owner and operator and its signature along with the independent registered professional engineer is all that is required on the closure plan certification. A signature line for WHC will not be added to the certification.

Ecology Response 1: The response is contrary to the statement at the paragraph 4 of page $i j i$ in the closure plan. Also, according to the Hanford Facility Dangerous Waste Permit (Site wide permit), co-operator has to sign whatever he has done.

Ecology/RL/WHC Resolution: It was agreed that WHC does not sign on 'whatever' has to be done. It was agreed that the owner/operator and licensed independent professional engineer were the only signatures required.

57. T7-1 and T7-2 Deficiency: These tables are inadequate.

Requirement: Appropriate methodologies and detection limits need to be listed. Also list method modifications and metal analyses.

Note: A11 method modifications must be approved by Ecology.

RL/WHC Response 1: Methodologies 1isted in Tables 7-1 and 7-2 are for EAL analyses. Analytical levels in Tables 7A-1 and 7A-2 will be revised from Level III to Level II. No metals have been proposed as analytes of interest in this plan.

New text will be included at the end of Section 7.2 .4 and in Section 7A.7 indicating that the EAL will work to controlled manual(s). Copies of the manuals will be made available to Ecology for review and approval when issued by WHC. WHC will have 
HANFORD PATROL ACADEMY DEMOLITION SITES CLOSURE PLAN NOTICE OF DEFICIENCY RESPONSE TABLE
September 30, 1993

Page 46 of 51

No. Page/Line No. Comment/Response

Ecology-approved procedures in place in advance of sampling and analysis.

Additional discussion will be provided at the end of Section 7.2.2 regarding future submittal of analytes tables for confirmatory sampling (and verification sampling as necessary).

A footnote will be added to Tables 7-1 and 7-2 to indicate that PQLs are identified in Tables $7 A-1$ and $7 A-2$. (Clarification to be provided by Ecology).

Ecology Response 1: The terminologies in the tables are not accurate. For example, TCL is for CLP, not SW-846. Correct the mistake. See also NOD No. 65 for the requirements of detection limits and methodologies.

Ecology/RL/WHC Resolution: Tables 7-1 and 7-2 and 7A-1 and 7A-2 will be removed from Rev. 1. Through the DQO process, all sampling and analytical concerns were resolved. Constituents of concern and analytical methods were identified and agreed to by all parties. See the SAP for specific agreements.

58. $8-2 / 26-28$

Deficiency: The plan does not answer the following questions: How will access to the contaminated areas be controlled when even the fence posts marking the location must be removed during use of the firing range? Will the firing range be closed until CERCLA remediation takes place? When is the CERCLA study and remediation scheduled to take place?

Requirement: Revise to provide answers. 
HANFORD PATROL ACADEMY DEMOLITION SITES CLOSURE PLAN NOTICE OF DEFICIENCY RESPONSE TABLE
September 30, 1993

Page 47 of 51

RL/WHC Response 1: The signs are affixed to poles that are removed from the post holes during firing activities. Upon completion of the firing activities the signs are returned to the post hole. The firing range will be maintained under controlled access throughout the firing activities.

The firing range will remain in operation and will not be closed until CERCLA remediation takes place.

The CERCLA study and remediation schedule is being prepared by the U.S. Army Corps of Engineers.

Ecology Response 1: Are those present kept off the demo. areas during firing events? See the earlier comment on the same subject. Include in next revision the description of control access procedure to the two demolition sites during use of the firing range according to WAC 173-303-310.

Ecology/RL/WHC Resolution: Administrative controls keep personnel out of Closure Area No. 1 during firing events.

Information regarding access to the HPADS will be included in Rev. I of the closure plan.

59. APP 5A-4/27-28 Requirement: Provide hydraulic properties that are available.

RL/WHC Response 1: No hydraulic studies were performed in the immediate area. The best available reference is, DOE-RL, 1990 Phase 1 Remedial Investigation Report for the Hanford Site 1100EM-1 Operable Unit.

Ecology Response 1: Concur. 
HANFORD PATROL ACADEMY DEMOLITION SITES CLOSURE PLAN NOTICE OF DEFICIENCY RESPONSE TABLE
September 30, 1993

Page 48 of 51

No. Page/Line No. Comment/Response

Concurrence

60. APP $7 A-1 / 32-33$

Deficiency: Confirmation samples cannot be analyzed by a "mobile laboratory" to determine the presence of contaminants of concern.

Requirement: Revise the plan.

RL/WHC Response 1: Refer to NOD No. 2 comment response.

Ecology Response 1: Concur.

Ecology/RL/HHC Resolution: Throughout the closure plan, references to using the mobile laboratory will be removed. offsite laboratories capable of EPA analytical level III will be used for all soil samples. 61. APP 7A-1/40-45 Requirement: If remediation is required, confirmatory samples are
required and must be done in an Ecology approved laboratory, not a mobile laboratory.

RL/WHC Response 1: Refer to NOD No. 2 comment response.

Ecology Response 1: Concur. 
HANFORD PATROL ACADEMY DEMOLITION SITES CLOSURE PLAN NOTICE OF DEFICIENCY RESPONSE TABLE
September 30, 1993

Page 49 of 51

NNo. Page/Line No. Comment/Response

Ecology/RL/WHC Resolution: Throughout the closure plan, references to using the mobile laboratory will be removed. Offsite laboratories capable of EPA analytical level III will be used for all soil samples.

62. APP $7 A-2 / 1-15$

Requirement: EPA-QAMS-005/80, "Interim Guidelines and Specifications for Preparing Quality Assurance Project Plans", should also be referenced.

RL/WHC Response 1: This information will be included.

Ecology Response 1: Concur.

Ecology/RL/WHC Resolution: The text reference will be incorporated in Rev. 1 .

63. APP $7 A-3 / 23-44$

Requirement: These samples are not expected to be classified as "radioactive"; therefore, they must be shipped off-site to an Ecology approved 1aboratory.

RL/WHC Response 1: Lines 35-39 will be revised to be consistent with the comment response for NOD No. 2 .

Ecology Response 1: Concur.

Ecology/RL/WHC Resolution: The HPADS is not a radiologically controlled area; this section will be deleted from Rev. 1. The samples will be radiation released before being shipped offsite for analysis. 
HANFORD PATROL ACADEMY DEMOLITION SITES CLOSURE PLAN NOTICE OF DEFICIENCY RESPONSE TABLE
September 30, 1993

Page 50 of 51

No. Page/Line No. Comment/Response

Concurrence

64. APP $7 A-5 / 9-11$

Deficiency: It states that Tables $7 A-1$ and $7 A-2$ identify the methodology and analyte-specific quantitation limits, but they do not.

Requirement: Correct these tables to contain this information.

RL/WHC Response 1: Methodology and quantitation limits are specified in the tables. Also refer to NOD No. 57 comment response. (Clarification to be provided by Ecology).

Ecology Response 1: Concur.

Ecology/RL/WHC Response: The tables and references to them will be deleted from Rev. 1. Information on the quantitation limits for the agreed on analyses is found in SW-846.

65. APP $7 A-9 /$ al1

Deficiency: This section is incomplete.

Requirement: Ca11 out methodology for characterization.

RL/WHC Response 1: Clarification to be provided by Ecology.

Ecology Response 1:

A. Give the specific method No. from SW-846.

B. PQLs are different for different materials at different laboratories. Thus, relate them to each contaminant and the laboratories which will be used to test them.

Ecology/RL/WHC Resolution: The agreed on EPA analysis methods are summarized in the SAP and the PQLS for each analytical method are summarized in SW-846. 
HANFORD PATROL ACADEMY DEMOLITION SITES CLOSURE PLAN NOTICE OF DEFICIENCY RESPONSE TABLE
September 30, 1993 Page 51 of 51

No. Page/Line No.

Comment/Response

Concurrence

66. APP 7A-10/18-19 Deficiency: The reference provided for validation procedures, "Data Validation Procedures for Chemical Analysis"

(WHC-SD-EN-SPP-002), is a validation procedure for contract

Laboratory Program (CLP) sample data, not analyses performed under SW-846.

Requirement: The correct reference should be "Sample Management and Administration" (WHC-CM-5-3).

RL/WHC Response 1: The reference will be corrected.

Ecology Response 1: Concur.

Ecology/RL/WHC Resolution: Date Validation Procedures for Chemical Analyses (WHC-SD-EN-SPP-002) provides procedures to WHC staff and subcontractors tasked with the validation of chemical analytical data produced as the result of Hanford Site environmental investigations. This document is a supplement to Sample Management and Administration (WHC-CM-5-3), which includes validation procedures for sample data performed under SW-846. 
DOE/RL-92-39, Rev. 1

$12 / 15 / 94$

The Hanford Site is owned by the U.S. Government and operated by the U.S. Department of Energy, Richland Operations Office. Dangerous waste and mixed waste (containing both radioactive and dangerous components) are produced and managed on the Hanford Facility. The dangerous waste is regulated in accordance with the Resource Conservation and Recovery Act of 1976 and the State of Washington Hazardous Waste Management Act of 1976 [as administered through the Washington State Department of Ecology "Dangerous Waste Regulations," Washington Administrative Code 173-303]. The radioactive component of mixed waste is interpreted by the U.S. Department of Energy to be regulated under the Atomic Energy Act of 1954; the nonradioactive dangerous component of mixed waste is interpreted to be regulated under the Resource Conservation and Recovery Act and Washington Administrative Code 173-303.

For purposes of the Resource Conservation and Recovery Act and the Washington State Department of Ecology "Dangerous Haste Regulations," the Hanford Site is considered to be a single facility. The single dangerous waste permit identification number issued to the Hanford Site by the U.S. Environmental Protection Agency and the Washington State Department of Ecology is U.S. Environmental Protection Agency/State Identification Number HA7890008967. This identification number encompasses over 60 treatment, storage, and/or disposal units within the Hanford Site. A11 waste management activities carried out under the assigned identification number are considered to be 'onsite'.

Hestinghouse Hanford Company is a major contractor to the U.S. Department of Energy, Richl and Operations Office and serves as co-operator of the Hanford Patrol Academy Demolition Sites, the unit addressed in this closure plan.

Westinghouse Hanford Company is identified in the closure plan as a 'co-operator' and signs in that capacity. Any identification of Westinghouse Hanford Company as an 'operator' elsewhere in this closure plan is not meant to conflict with Westinghouse Hanford Company's designation as a co-operator but rather is based on Westinghouse Hanford Company's contractual status (i.e., as an operations and engineering contractor) for the U.S. Department of Energy.

The Hanford Patrol Academy Demolition Sites Closure Plan consists of a Hanford Facility Dangerous Waste Part A Permit Application, Form 3, (Revision 4), and a closure plan. An explanation of the Part A Form 3 submitted with this closure $\mathrm{plan}$ is provided at the beginning of the Part $A$ section. The closure plan consists of nine chapters and six appendices.

This Hanford Patrol Academy Demolition Sites Closure Plan submittal contains information current as of December 15, 1994. 
DOE/RL-92-39, Rev. 1

$12 / 15 / 94$

This page intentionally left blank. 
3 4

5

6

7

8

9

10

11

12

13

14

15

16

17

18

19

21

22

23

\section{DOCUMENT CONTENTS}

FOREWORD

ACRONYMS AND ABBREVIATIONS

PART A

1.0 INTRODUGTION :

2.0 FACILITY DESCRIPTION

3.0 PROCESS INFORMATION

4.0 WASTE CHARACTERISTICS

5.0 GROUNDWATER MONITORING

6.0 CLOSURE STRATEGY AND PERFORMANCE STANDARDS

7.0 CLOSURE ACTIVITIES

8.0 POSTCLOSURE PLAN

9.0 REFERENCES

\section{APPENDICES}

\section{$2 A$ PHOTOGRAPHS}

3A SOIL SAMPLING INFORMATION FOR THE HANFORD PATROL ACADEMY DEMOLITION SITES MARCH 1987 DETONATION EVENT

3B HANFORD WEATHER STATION METEOROLOGICAL DATA FOR HANFORD PATROL ACADEMY DEMOLITION SITES DETONATIONS OCCURRING AFTER 1984

4A WASTE INVENTORIES

5A GROUNDWATER DATA FOR THE HANFORD PATROL ACADEMY DEMOLITION SITES

7A QUALITY ASSURANCE PROJECT PLAN FOR SOIL SAMPLING AND ANALYSIS FOR THE HANFORD PATROL ACADEMY DEMOLITION SITES

7B TRAINING COURSE DESCRIPTIONS

$7 C$ SAMPLING AND ANALYSIS PLAN 
DOE/RL-92-39, Rev. 1 $12 / 15 / 94$

This page intentionally. left blank. 
ASTM

CERCLA

CFR

DOE-RL

DQO

Ecology

EII

EPA

GPR

HEIS

HPADS

IRIS

$K D$

MDL

MTCA

QAPjP

QI

QR

RCRA

RPP

SAP

SMO

SWMU

Tri-Party Agreement

TSD

WAC

WHC-CAS

\section{ACRONYMS AND ABBREVIATIONS}

American Society for Testing and Materials

Comprehensive Environmental Response, Compensation, and Liability Act of 1980

Code of Federal Regulations

U.S. Department of Energy, Richland Operations Office data quality objective

Washington State Department of Ecology environmental investigation instruction U.S. Environmenta7 Protection Agency

ground-penetrating radar

Hanford Environmental Information System Hanford Patrol Academy Demolition Sites

integrated risk information system (database)

known distance

method detection limit

Model Toxics Control Act

quality assurance project plan

qual ity instruction

quality requirement

Resource Conservation and Recovery Act of 1976

RCRA Past Practice

Sampling and Analysis Plan

sample management organization

solid waste management unit

Hanford Federal Facility Agreement and Consent Order treatment, storage, and/or disposal

Washington Administrative Code

Westinghouse Hanford Company Commercial

Analytical Services 


\section{DEFINITION OF TERMS}

Definitions are based on use throughout this document.

Accuracy--The degree of agreement between a measurement (or the mean value of a set of measurements) to the true value. Accuracy is the measure of the bias in a measurement system. Sampling accuracy normally is assessed through the" evaluation of sample blanks, while analytical method accuracy and specific sample matrix effects are assessed through the analysis of control standards and spiked samples.

Audit--Audits are considered to be systematic checks to verify the quality of operation of one or more elements of the total measurement system. In this sense, audits could be of two types: (1) performance audits, in which quantitative data are independently obtained for comparison with data routinely obtained in a measurement system or (2) system audits, involving a qualitative onsite evaluation of laboratories or other organizational elements of the measurement system for compliance with established quality assurance program and procedure requirements. For environmental investigations at the Hanford Site, performance audit requirements are fulfilled by periodic submittal of blind samples to the primary laboratory or the analysis of split samples by an independent laboratory. System audit requirements are implemented through the use of standard surveillance procedures.

Comparability--Comparability is an expression of the relative confidence with which one data set might be compared with another.

Completeness--Completeness is a quantitative parameter expressing the percentage of measurements judged to be valid.

Deviation--Deviation refers to a planned departure from established criteria that might be required as a result of unforeseen field situations or that might be required to correct ambiguities in procedures that may arise in practical applications.

Facility/facility--Dependent on context, the term 'facility', as used in this closure plan, could refer to the following.

The Hanford Facility is a single Resource Conservation and Recovery Act (RCRA) facility identified by the U.S. Environmental Protection Agency (EPA)/State Identification Number WA7890008967 that consists of over 60 treatment, storage, and/or disposal (TSD) units conducting dangerous waste management activities. These TSD units are included in the Hanford Facility Dangerous Waste Part A Permit Application (DOE-RL 1988b). The Hanford Facility consists of all contiguous land, and structures, other appurtenances, and improvements on the land, used for recycling, reusing, reclaiming, transferring, storing, testing, or disposing of dangerous waste, which, for the purposes of the RCRA, are owned by the U.S. Government and operated by the DOE-RL. 
1

A facility as defined in WAC 173-303-040, i.e., building nomenclature commonly used at the Hanford Site. In this context, the term 'facility' remains as part of the title for various TSD units (e.g., 2727-S Storage Facility, Hexone Storage and Treatment Facility).

Nonconformance--A nonconformance is a deficiency in characteristic, documentation, or procedure that renders the quality of material, equipment, services, or activities unacceptable or indeterminate. When the deficiency is of a minor nature, does not effect a permanent or significant change in quality. if it is not corrected, and can be brought into conformance with. immediate corrective action, the deficiency shail not be categorized as a nonconformance. However, if the nature of the condition is such that it cannot be immediately and satisfactorily corrected, it shall be documented in compliance with approved procedures and brought to the attention of management for disposition and appropriate corrective action.

Precision--Precision is a measure of the repeatability or reproducibility of specific measurements under a given set of conditions. Specifically, precision is a quantitative measure of the variability of a group of measurements compared to their average value. Precision normally is expressed in terms of standard deviation, but also could be expressed as the coefficient of variation, relative standard deviation, or range (i.e., maximum value minus minimum value). Precision is assessed by means of duplicate and/or replicate sample analysis.

Quality assurance--Quality assurance refers to the total integrated quality planning, quality control, quality assessment, and corrective action activities that collectively ensure that the data from monitoring and analysis meet all end user requirements and/or the intended end use of the data.

Quality assurance project plan--The quality assurance project plan is an orderly assembly of management policies, project objectives, methods, and procedures that defines how data of known quality will be produced for a particular project or investigation.

Quality control--Quality control refers to the routine application of procedures and defined methods to the performance of sampling, measurement, and analytical processes.

Representativeness--Representativeness is the degree to which data accurately. and precisely represent a characteristic of a population parameter, variations at a sampling point, or an environmental condition. Representativeness is a qualitative parameter that is most concerned with the proper design of a sampling program.

Site-wide background--The natural background established for the Hanford Site. This does not include contributions from anthropogenetic sources unrelated to Hanford Site operations.

Validation--Validation refers to a systematic process of reviewing a body of data against a set of criteria to provide assurance that the data are acceptable for their intended use. 
1 Verification--Verification refers to the process of determining whether

2 procedures, processes, data, or documentation conform to specified

3 requirements. Verification activities might include inspections, audits, 4 surveillances, or technical review. 


\section{PART A}

The Part A Permit Application, Form 1, included in this closure plan was submitted to the Washington State Department of Ecology in May 1988. The Part A Permit Application, Form 1, consists of three pages.

The Part A Permit Application, Form 3, covers the Hanford Patrol Academy Demolition Sites. The original Part A Permit Application, Form 3, was submitted on November 1, 1985. Revision 1 of the Part A Permit Application, Form 3 was prepared to add new demolition sites, and was submitted on August 15, 1987. Revision 2 of the Part A Permit Application, Form 3, was prepared to separate several demolition sites into individual Part A permit applications and to add Hestinghouse Hanford Company as co-operator. Revision 2 was submitted on November 16, 1987. Revision 3 of the Part A Permit App 7ication, Form 3, updates waste codes based on data obtained from the waste inventory. Revision 4 of the Part A Permit Application, Form 3, was prepared to delete state-only dangerous waste code $\mathrm{WCOI}^{\mathrm{C}}$ and replace it with WCO2 in accordance with WAC 173-303, as amended in December 1993.

The Part A Permit Application, Form 3 (Revision 4), included with this closure plan consists of five pages, one figure, and one photograph. 
D0E/RL-92-39, Rev. 1

$12 / 15 / 94$

1

2

4

5

This page intentionally left blank. 


\section{$05 / 19 / 88$ \\ Page 1 of 3}

\begin{tabular}{|c|c|c|c|}
\hline FORA & 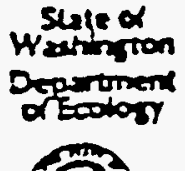 & $\begin{array}{l}\text { WASHWOTOW STATE } \\
\text { ONGEROUS WASTE PERUT GENERUL RFORUUTOH }\end{array}$ & 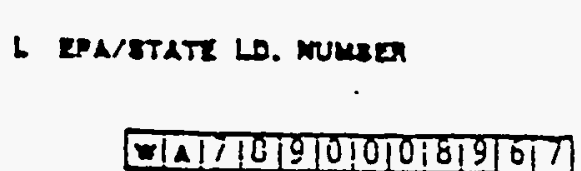 \\
\hline & & 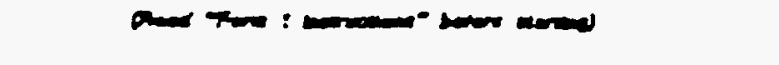 & \\
\hline
\end{tabular}

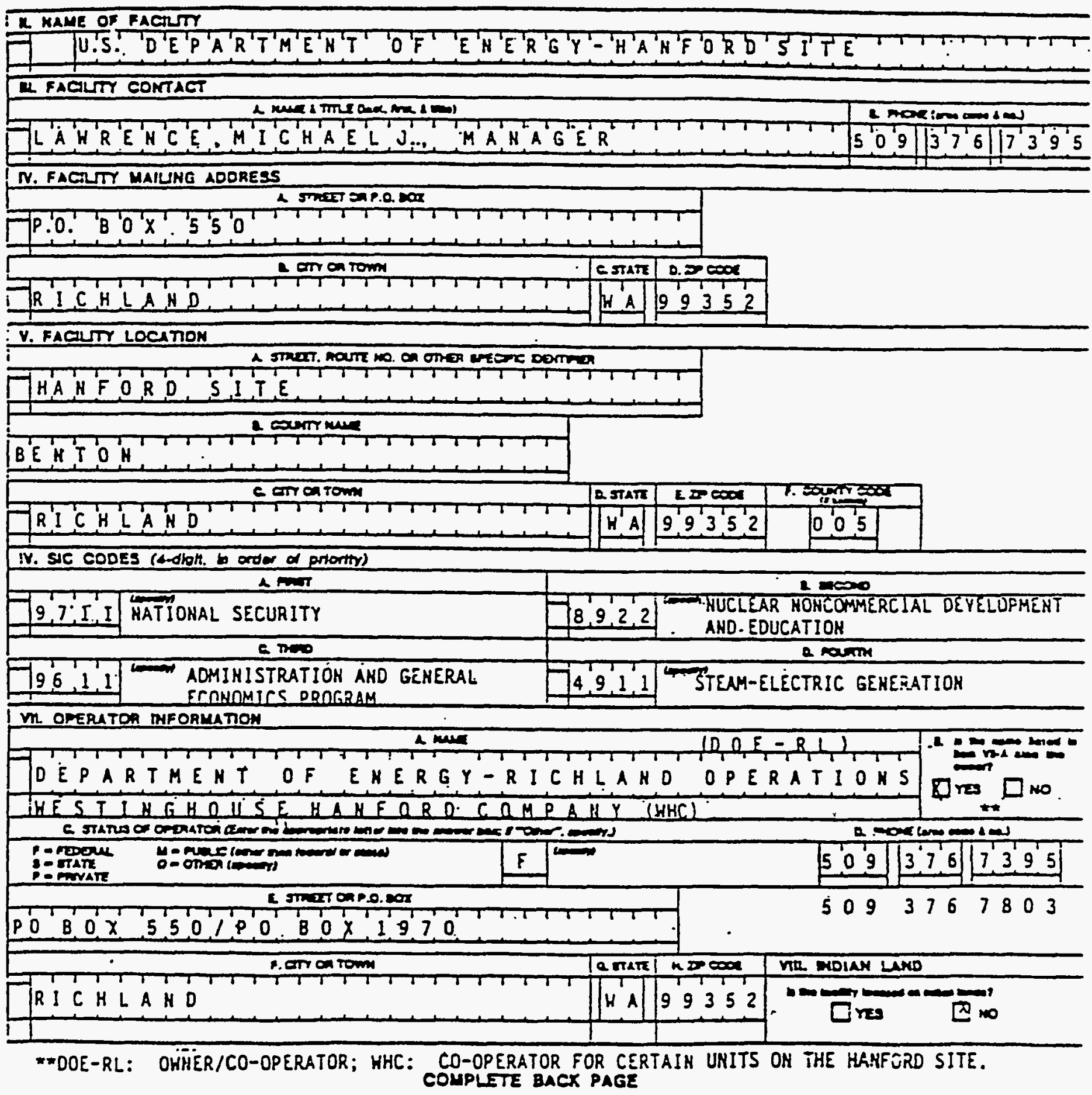

cer coads

$\infty$ 


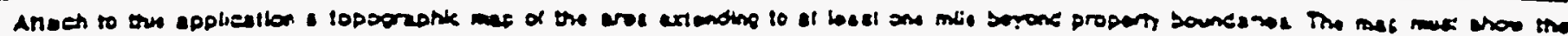

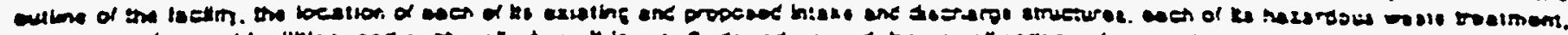

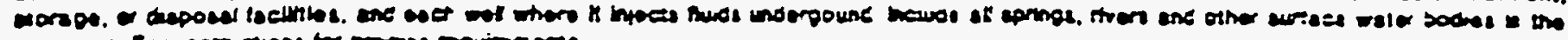

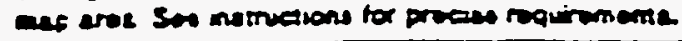

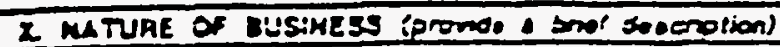

- NATIONAL DE? INSE NUCLEAR MATERIAL PRODUCTION

- EMERgY RESEARC! AND TECHMOLOGY DEYELOPMENT

- DEFEHSE hUCLEAR haSTE MANagEMENT

- BYPRJDUCT STEAM, SOLD FOR ELECTRIC POWEŔ GENER̃ATION

AND SIC 15: BUILOING CONSTRUCTIOK - GENERAL COHTRACTORS AND OPERAIIVE ILI:DERS

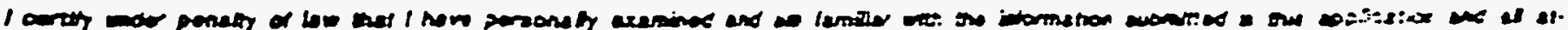

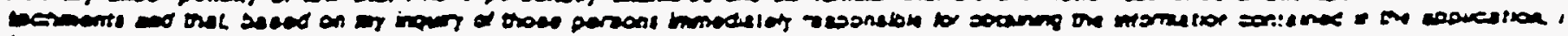

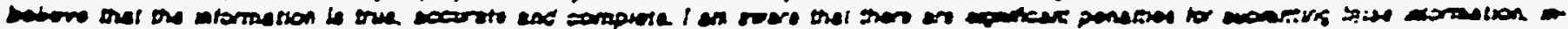

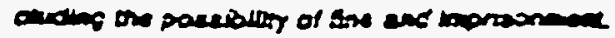
-

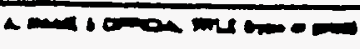

SEE ATTACHMENT

2000

$\left.\right|^{<-7=0}$


Fopa 1

DANGEROUS HASTE PERMT GENERAL INFORHATION

\section{CERTIEICATIOH}

I certify under penalty of law that i have personally examines and am familiar with the information submitted in this application and ail attachments, and that based on my inquiry of those incividua!s imediaie:y responsible for obtaining the information, I beilieve that the sibmitieo information is true, accurate, and compiete. I am awiare that ihere are significant penalties for submitting false information inciucing the possibility of fine and imprisonment.
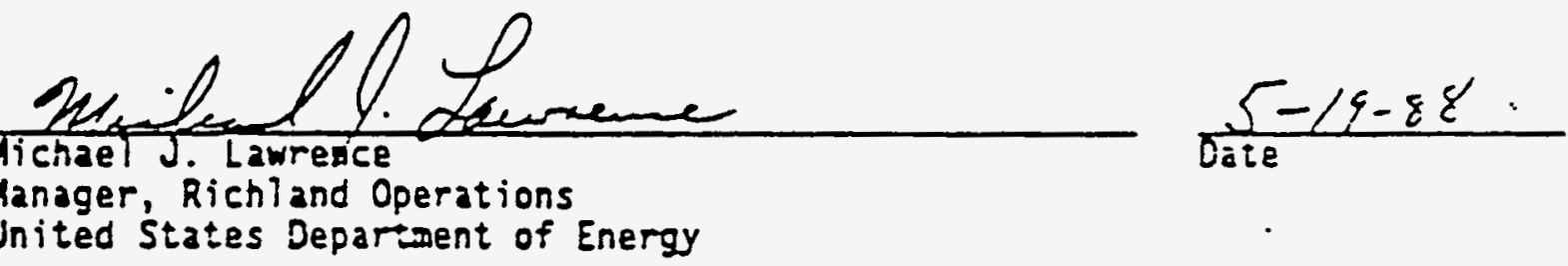

Manager, Richl and Operations

United States Deparaent of Energy

\section{N.m-loph.}

पilliam M. Jaक्षo?

President

Hestinghouse Hanford Company

co-operator
$5 / 13 / 86$ 
Ploser pint or type in tho unshadod areas only

(ithth arees ere speced for elite typo, (ce.e 12 charactor/nah).

FORM

3

DANGEROUS WASTE PERMIT APPLICATION

1. EPASTATE L.D. NUMBER

\begin{tabular}{|l|l|l|l|l|l|l|l|l|l|l|l|}
\hline$W$ & $A$ & 7 & 8 & 9 & 0 & 0 & 0 & 8 & 0 & 6 & 7 \\
\hline
\end{tabular}

FOR OFFICIAL USE ONLY

\begin{tabular}{c|c}
\hline APPLICATION & DATE RECEIVED \\
APPROVED & (mo.doY $a$ Y. \\
\hline
\end{tabular}

COMMENTS

II. FIRST OR REVISED APPLICATION

Place an " $X$ " In the appropriate box in A or B bolow (mark one box only) to Indleate whether this is the first application you are submitting for your factily or a revised

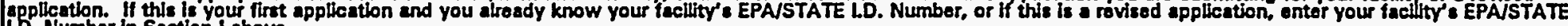
L.D. Number in Section I above.

A. FIRST APPLCATION (placo en " $X^{\circ}$ below and provido the eppropriate dato)

D1. EXISTING FACILITY isee Instructions for defintion of "existing" faclity. Completo ktem below.)

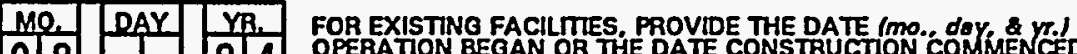

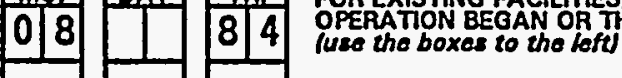

B. AEVISED APPLICATION Golace an " $X$ " below and complote Section I abovol

D] 1. FACILITY HAS AN INTERIM STATUS PERMIT

2. NEW FACIUTY (Comploto kam betow)

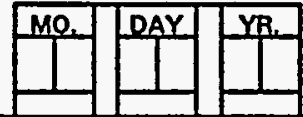

FOR NEW FACILTIES.

Imo deY \& $y$ I OPERA-

EXPECTED TO BEGIN

2. FACILTY HAS A FWAL PERMTT

III. PROCESSES - CODES AND CAPACITIES

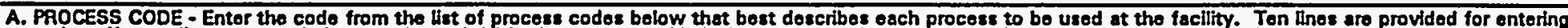

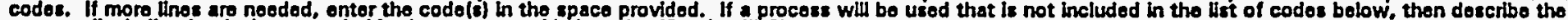
process (including its desian copecity) in the space provided on the (Section III-C).

B. PROCESS DESION CAPACTYY - For each codo entered in column A enter the capacity of the process.

1. AMOUNT - Entor the amount.

2. UNIT OF MEASURE - For esch amount entered in column B(1), entor tho codo from the list of unit moasure codes bolow that doseribes the unit of monsure used. Only the units of moasure that aro listed below should be used.

\begin{tabular}{lll} 
& PRO & APPROPRIATE UNITS OF \\
PROCESS & CESS & MEASURE FOA PROCESS \\
\hline
\end{tabular}

Storago:

CONTALNER (barrol, drum, etc)

WANK PALE PILE

SURFACE IMPOUNDMENT

Sol

GALONS OR LTER

CALLONS OR LITER

CUBIC METERS

SO4 GALLONS OR ITERS

Dleposal:

NAECTION WELL

LANDFILL

DBO GALLONS OR LTERS

DB1 ACFE-FEET the volume that would cover one gcre to depth of one foot)

082 ACRES OR HECTARES

D82 ACRES OR HECTARES

LAND APPLICATION

OCEAN DISPOSAL

SURFACE IMPOUNDMENT

DB4 GALLONS OR LITERS

\begin{tabular}{|c|c|c|}
\hline $\begin{array}{l}\text { UNTT OF } \\
\text { MEASUAE } \\
\text { CODE }\end{array}$ & UNIT OF MEASURE & $\begin{array}{l}\text { UNT OF } \\
\text { MEASURE } \\
\text { CODE }\end{array}$ \\
\hline 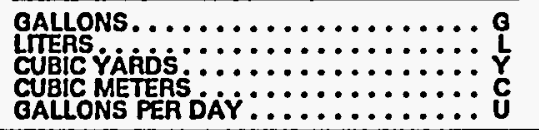 & $\begin{array}{l}\text { LTERS PER DAY .. } \\
\text { TONS PER HOUR:. } \\
\text { METRICTONS PEA } \\
\text { GALLONS PER HOU } \\
\text { LIERS PER HOUR. }\end{array}$ & $\begin{array}{l}\ldots \ldots \mathrm{V} \\
\ldots \ldots \mathrm{V} \\
\cdots \cdots \mathrm{H}\end{array}$ \\
\hline
\end{tabular}

\begin{tabular}{|c|c|c|}
\hline PROCESS & $\begin{array}{l}\text { PRO } \\
\text { CESS } \\
\text { CODE }\end{array}$ & $\begin{array}{l}\text { APPROPAIATE UNTS OF } \\
\text { MEASURE FOA PROCESS } \\
\text { DESIGN CAPACITY }\end{array}$ \\
\hline \multicolumn{3}{|l|}{ Troatment: } \\
\hline TANK & Tor & GALLONS PER DAY OR \\
\hline SURFACE IMPOUNDMENT & TO2 & GALLONS PER DAY OR \\
\hline WNCINERATOR & T03 & $\begin{array}{l}\text { TONS PER HOUR OR } \\
\text { METRIC TONS PER HOUR: } \\
\text { GALLONS PER HOUR OR } \\
\text { LTERS PER HOUR }\end{array}$ \\
\hline
\end{tabular}

OTHER (Uso for physical, chemlcal, TO4 thermal or biological treatment procosses not occurring in tanks. surface impoundments or inciner-
ators. Describo the processes in ators. Describe the processes in

GALLONS PER DAY OR IITERS PER DAY

EXAMPEF

hold

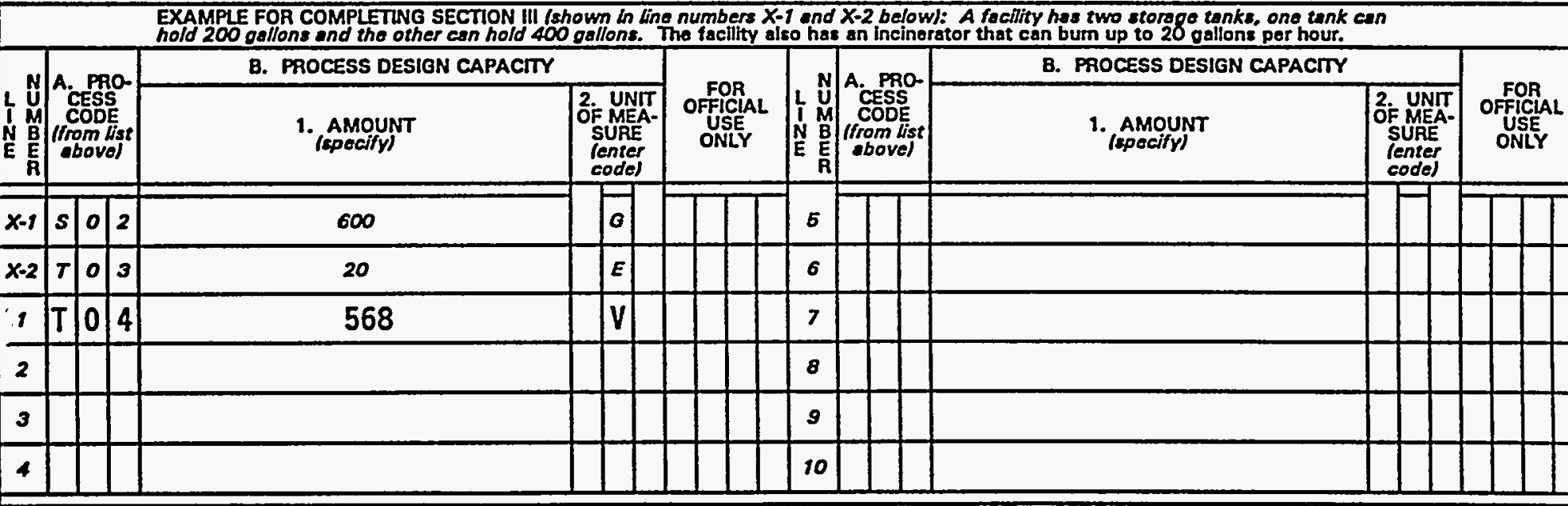


The Hanford Patrol Academy Demolition Sites (HPADS) were two demolition sites (Closure Area No. 1 and No. 2 identified on page 7 of 7) located near the. 1100 Area of the Hanford Facility. These demolition sites were used to detonate discarded explosive chemical products generated on the Hanford Site that were determined to either be in excess or beyond designated shelf life (T04). The treatment design capacity of the HPADS was 568 liters (150 gallons) of discarded explosive chemical products per day. The last detonation event at the HPADS occurred on October 27, 1991.

IV. DESCRIPTION OF DANGEROUS WASTES

A. DANGEROUS WASTE NUMBER - Enter the four digit number from Chapter 173.303 WAC for each listed dangorous waste you will handle. II you handlo denporous wastos which aro not listed in Chapter 173-303 WAC, enter the four digit number(s) that describes the charactoristics and/or the toxic contaminants of those dangerous wastes.

B. ESTIMATED ANNUAL QUANTITY - For each listed waste entered in column A estimate thn quantity of that wasto that will be handled on an annual basis. For oach characteristic or toxic contaminant entered in column $A$ cstimate the total annual quantity of all the non-listed waste(s) that will be handled which possese that characteristic or cont aminant.

C. UNIT OF MEASURE - For oach quantity entered in column B onter the unit of meosure codc. Units of moasure which must be used and the appropriate codes aro:

ENGLISH UNIT OF MEASURE
POUNDS $\ldots \ldots \ldots \ldots \ldots \ldots \ldots \ldots \ldots \ldots \ldots$

$\frac{\text { METRIC UNTT OF MEASURE }}{\text { KILOGRAMS } \ldots \ldots \ldots \ldots \ldots \ldots \ldots \ldots \ldots}$

If facility records use any other unit of measure for quantity, the units of measure must be converted into one of the required units of measure taking into account the approprato density or speclfic grevity of the waste.

D. PROCESSES

1. PROCESS CODES:

For listed dangerous waste: For each listod dangerous waste entered in column A sclect the code(s) from the list of process codes contained in Section III to indicato how the waste will bo stored, treated, and/or disposed of at the facility.

For non-listod dangarous wastes: For oach characteristic or toxic contaminant entered in Column A, soloct the code(s) from the list of process codes contained in Section III to indicato all the processes that will be used to store, treat, and/or dispose of all the non-listed dangerous wastes that possess that characteristic or toxic contominant.

Note: Four spaces are provided for ontering process codes. If more are noeded: (1) Enter the first three as described abovo; (2) Enter "000" in the oxtremo right box of ltem IV-D(1); and (3) Enter in the space provided on page 4, the line number and the additional code(s).

2. PROCESS DESCRIPTION: II a code is not listed for a process that will be used, describe the process in the space provided on the form.

NOTE: DANGEROUS WASTES DESCRIBED BY MORE THAN ONE DANGEROUS WASTE NUMBER - Dangerous wastes that can be described by more than one Waste Number shall bo described on the form as follows:

1. Select one of the Dangerous Waste Numbers and enter it in column A. On the same line complete columns B. C, and D by estimating the total annusl quantity of the wasto and doscribing all the processes to be used to treat, store. and/or dispose of the waste.

2. In column $A$ of the next line entor the other Dangerous Waste Number that can be used to describe the waste. In column D(2) on that line enter "included with above" and make no other entries on that line.

3. Repeat step 2 for each other Dangerous Waste Number that can be used to describe the dangerous waste.

EXAMPLE FOR COMPLETING SECTION IV Ishown in line numbars $x-1, x-2, x-3$, and $x-4$ belowl - A facility will trant and disposa of an ostimated a00 pounds por yoar of chrome shavings from leather tanning and finishing operation. In addition. the facility will treat and dispose of throe non-listed wastes. Two wastes are corrosivo
only and thero will bo an estimated 200 pounds por yoar of each wastc. The other waste is corrosive and ignitable and there will be an ostimated 100 pounds por yoa of that wasto. Treatment will be in an incinerator and disposal will be in a landfill.

\begin{tabular}{|c|c|c|c|c|c|c|c|c|c|c|}
\hline \multirow{3}{*}{$\begin{array}{cc}\mathrm{L} & \mathrm{N} \\
\mathrm{I} & \mathrm{N} \\
\mathrm{N} & 0 \\
\mathrm{E} & \\
& \\
\end{array}$} & \multirow{2}{*}{\multicolumn{4}{|c|}{$\begin{array}{l}\text { DANGËROUS } \\
\text { WASTE NO. } \\
\text { (enter codol }\end{array}$}} & \multirow{3}{*}{$\begin{array}{l}\text { B. ESTIMATED ANNUAL } \\
\text { QUANTITY OF WASTE } \\
300\end{array}$} & \multirow{3}{*}{$\begin{array}{l}\text { C. UNIT } \\
\text { OF MEA- } \\
\text { SURE } \\
\text { Tonter } \\
\text { codel }\end{array}$} & \multicolumn{4}{|c|}{ D. PROCESSES } \\
\hline & & & & & & & \multicolumn{3}{|c|}{ 1. PROCESS CODES } & \multirow[t]{2}{*}{$\begin{array}{l}\text { 2. PROCESS DESCRIPTION } \\
\text { (if a code is not cntored in D(t)l }\end{array}$} \\
\hline & $k$ & 0 & 6 & 4 & & & $\left|\begin{array}{lll|lll}1 & 0 & 3 & 0 & 8 & 0\end{array}\right|$ & & & \\
\hline$x-2$ & 0 & 0 & 0 & 2 & 400 & $P$ & $\begin{array}{llllll}T_{0} & 0 & 0 & 8 & 0\end{array}$ & 1 & 1 & \\
\hline$|x-3|$ & 0 & 0 & 0 & 1 & 100 & $\boldsymbol{P}$ & $\begin{array}{llllll} & 0 & 0 & 0 & 0 & 0\end{array}$ & 1 & T & \\
\hline$x-4$ & $D$ & 0 & 0 & 2 & & & \begin{tabular}{lll|lll}
1 & 0 & 3 & 0 & 0 & 0
\end{tabular} & 11 & & included with above \\
\hline
\end{tabular}


Continued from page 2.

NOTE: Photocopy thls page before completing If you have more than 26 wastes to list.

L.D. NUMBER lentered from page 1 )

\begin{tabular}{|l|l|l|l|l|l|l|l|l|l|l|l|}
\hline$W$ & $A$ & 7 & 8 & 8 & 0 & 0 & 0 & 8 & 8 & 6 & 7 \\
\hline
\end{tabular}

N. DESCRIPTION OF DANGEROUS WASTES (continued)

\begin{tabular}{|c|c|c|}
\hline $\begin{array}{ll}1 & N \\
1 & 0 \\
N & 0 \\
E & .\end{array}$ & $\begin{array}{l}\text { A. } \\
\text { PANGEROUS } \\
\text { WASTE NO. } \\
\text { (enter codes }\end{array}$ & $\begin{array}{l}\text { B. ESTIMATED ANNUAL } \\
\text { QUANTITY OF WASTE }\end{array}$ \\
\hline
\end{tabular}

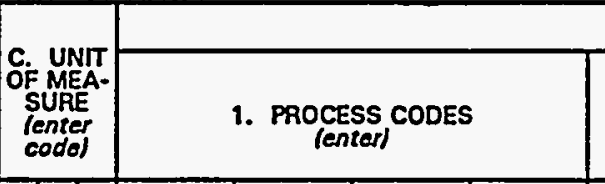

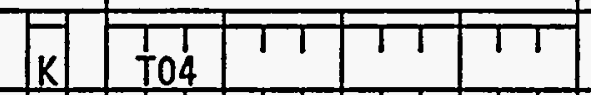

1 D 000.1

\begin{tabular}{llllll}
2 & 0 & 0 & 0 & 2 \\
\hline
\end{tabular}

\begin{tabular}{llllll}
3 & $D$ & 0 & 0 & 3 \\
\hline
\end{tabular}

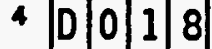

$\begin{array}{lllllll}5 & \mathrm{P} & 0 & 2 & 2\end{array}$

\begin{tabular}{llllll}
6 & $\mathrm{P}$ & 0 & 4 & 8 \\
\hline
\end{tabular}

\begin{tabular}{llllll}
7 & $P$ & 1 & 0 & 5 \\
\hline
\end{tabular}

\begin{tabular}{llllll}
8 & $\mathrm{U}$ & 1 & 0 & 8 \\
\hline
\end{tabular}

- \begin{tabular}{lllll}
\hline & 1 & 1 & 7 \\
\hline
\end{tabular}

\begin{tabular}{llllll}
10 & 4 & 1 & 3 & 3 \\
\hline
\end{tabular}

\begin{tabular}{lll|l|l|l|l}
11 & $\cup$ & 2 & 1 & 3 \\
\hline
\end{tabular}

$\begin{array}{llllll}12 & 0 & 2 & 3 & 4\end{array}$

\begin{tabular}{ll|llll}
13 & $H$ & $T$ & 0 & 1 \\
\hline
\end{tabular}

\begin{tabular}{lllllll}
14 & H & $\mathrm{T}$ & 0 & 2 \\
\hline
\end{tabular}

15 H

\begin{tabular}{llllll}
16 & $\mathrm{H}$ & $\mathrm{P}$ & 0 & 3 \\
\hline
\end{tabular}

17 H) C 002

18

19

20

21

22

23

34

25

26

ECL30-271 - ECY 030.31 Form 3
1,000

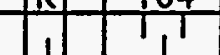

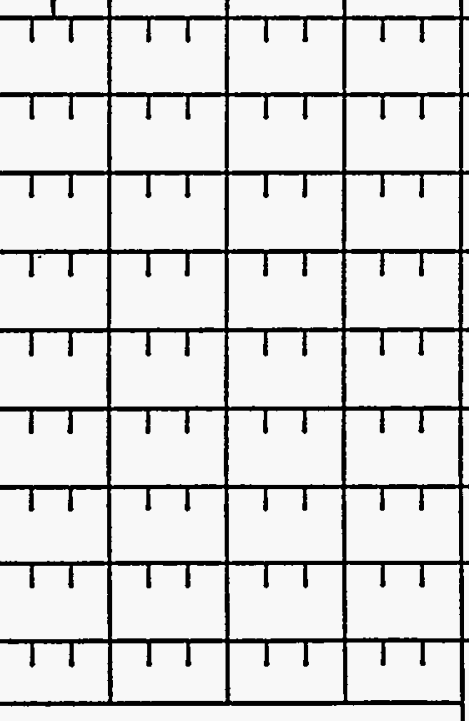

D. PROCESSES

\section{PROCESS DESCAIPTON \\ (If $\bullet$ code is not entered in DIII)}

Treatment-0ther (Demolition)

Included With Above

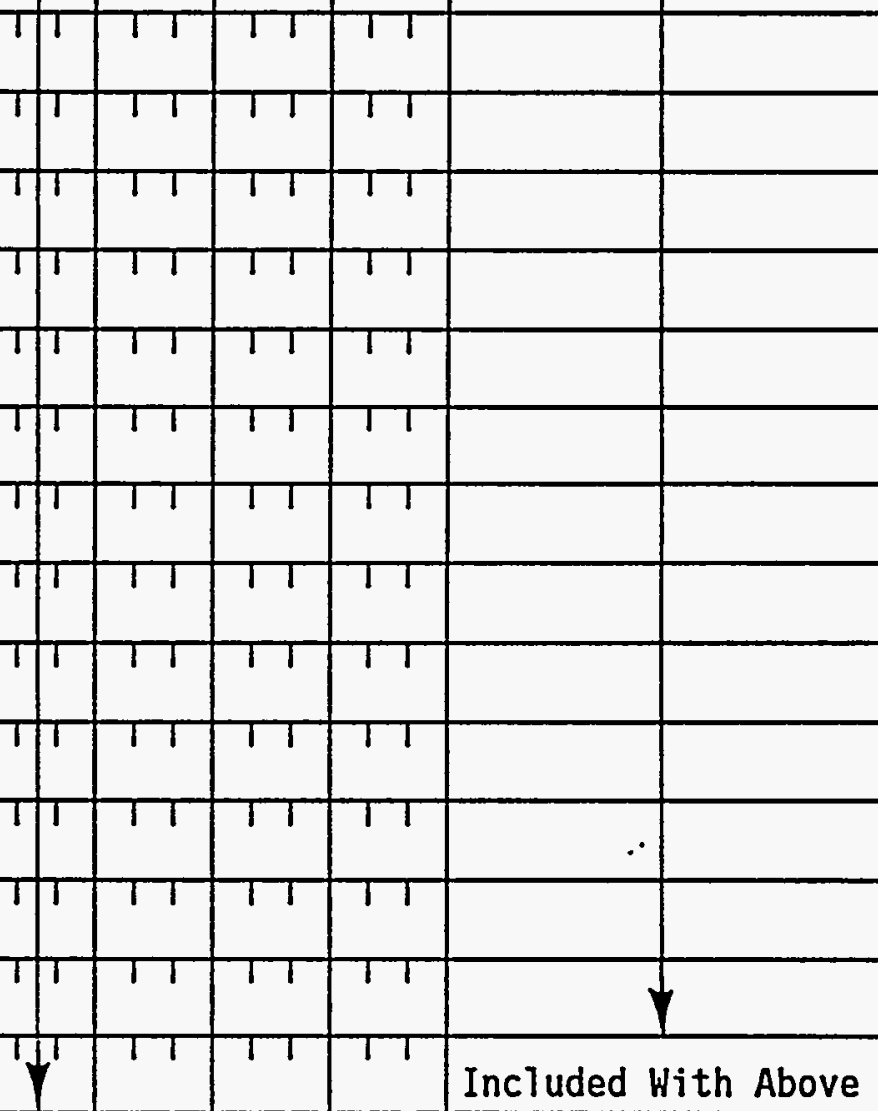

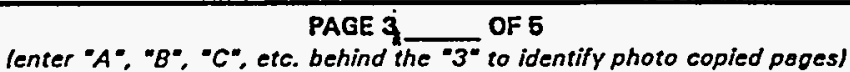

CONTINUE ON REVERSE 
Continued from the front.

$\because$. DESCRIPTION OF DANGEROUS WASTES (continued)

USE THIS SPACE TO LIST ADDITIONAL PROCESS CODES FROM SECTION D(1) ON PAGE 3.

The HPADS were used for the treatment of nonradioactive explosive, ignitable, shock-sensitive, and/or reactive discarded chemical products. The discarded chemical products treated at the HPADS all exhibited the dangerous waste characteristics of ignitability (DOOI) and reactivity (D003). Some of the discarded chemical products also exhibited the dangerous waste characteristic of corrosivity (DOO2) and may have the state-only designations for toxic extremely hazardous waste (WTO1), toxic dangerous waste (WTO2), persistent halogenated hydrocarbons, extremely hazardous waste, (HPO1), persistent polycyclic aromatic hydrocarbons, extremely hazardous waste, (WP03), and/or carcinogenic dangerous waste (HCO2). The Estimated Annual Quantity of Dangerous Waste (item IV.B) of 1,000 kilograms (2,204 pounds) represents the maximum total amount of discarded chemical products believed to have been treated at the HPADS.

v. FACILITY DRAWING Refer to attached drawing.

All existing facilitios must include in the space provided on page 5 a scale drawing of the facility (sae instructions for more datoill.

VI. PHOTOGRAPHS Refer to attached photographs.

All existing facilities must include photographs (aerial or ground-level/ that clearly delineate all existing structures; existing storage. treatment and disposal areas: and altes of future storago, treatmont or disposal areas (seo instructions for more deteill.

VII. FACILITY GEOGRAPHIC LOCATION This information is provided on the attached drawings and photos.

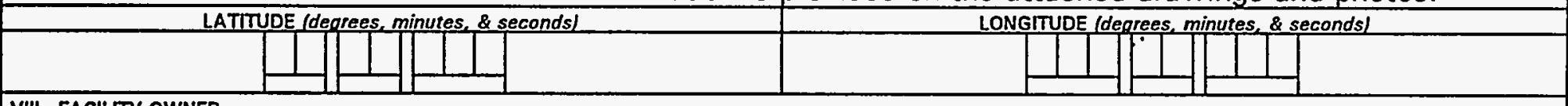

VIII. FACILITY OWNER A. If the facility owner is also the facility operator as listed in Section VII on Form 1, "General Information". place an " $X$ " in the box to the left and skip to Section IX
bolow.

B. If the facility owner is not the facility operator as listed in Section VII on Form 1. complete the following items:

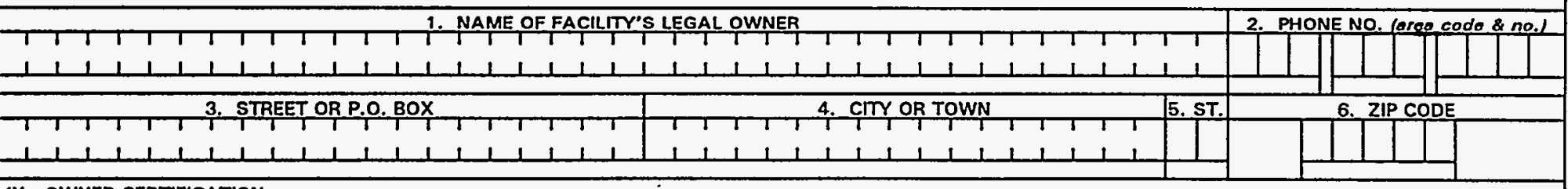

IX. OWNER CERTIFICATION

Tcertify undor penafty of law that l have personally examined and am familiar with the information submitted in this and all attached documents, and that based on my inquiry of those individuals immodiately responsible for obteining the informatipn, I believe that the submitted information is true, accurate, and complate. I am aware that there aro significant ponalties for submitting false information. including tho ppssibility f fine and imprisonment.

NAME (print or typol

John D. Hagoner, Manager

U.S. Department of Energy

Io ichland Operations Office
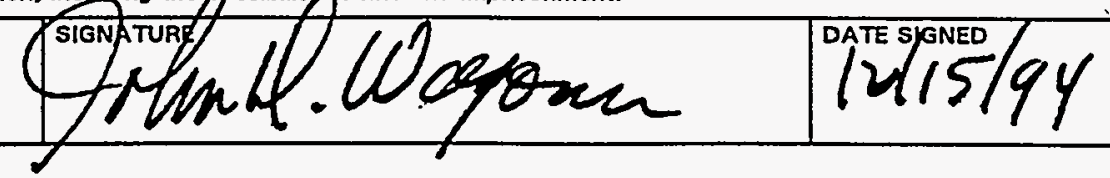

OPERATOR CERTIFICATION

artify under penalty of law that l have personally examined and am familiar with the information submitted in this and all attached documents, and that based on my inquiry of those individuals immodiatoly rosponsiblo for obtaining the information, lboliova that the submitted information is true, accurate, and complato. I am awero thet there aro sionificant penalties for submitting false information. including the possibility of fine and imprisonment.

\begin{tabular}{|l|l|}
\hline NAME (print or typol & SIGNATURE
\end{tabular} 


\section{OPERATOR CERTIFICATION}

I certify under penalty of law that I have personally examined and am familiar with the information submitted in this and all attached documents, and that based on my inquiry of those individuals immediately responsible for obtaining the information, I believe that the submitted information is true, accurate, and complete. I am aware that there are significant penalties for submitting false information, including the possibility of fine and imprisonment.
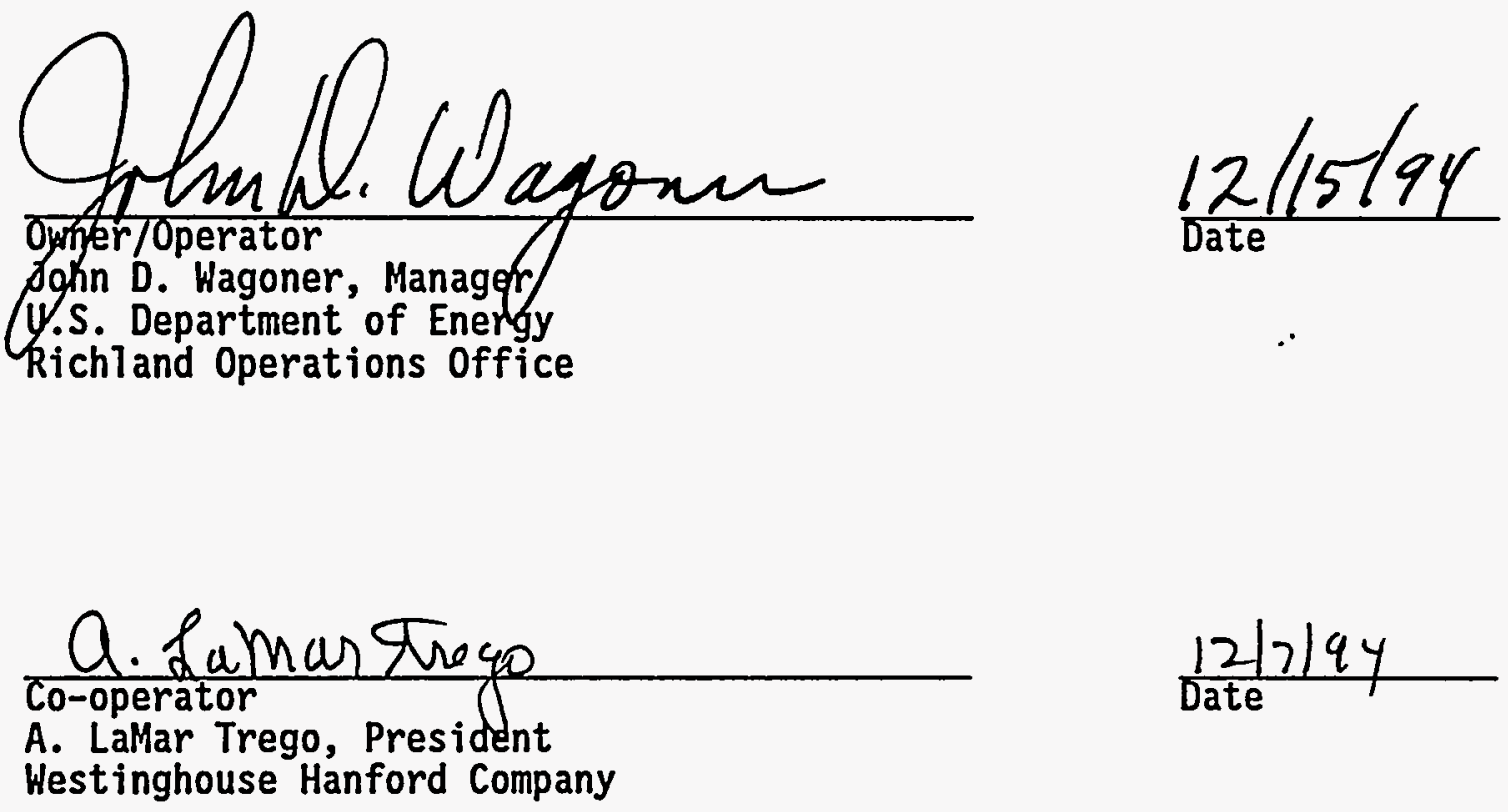
Hestinghouse Hanford Company 
Hanford Patrol Academy Demolition Sites

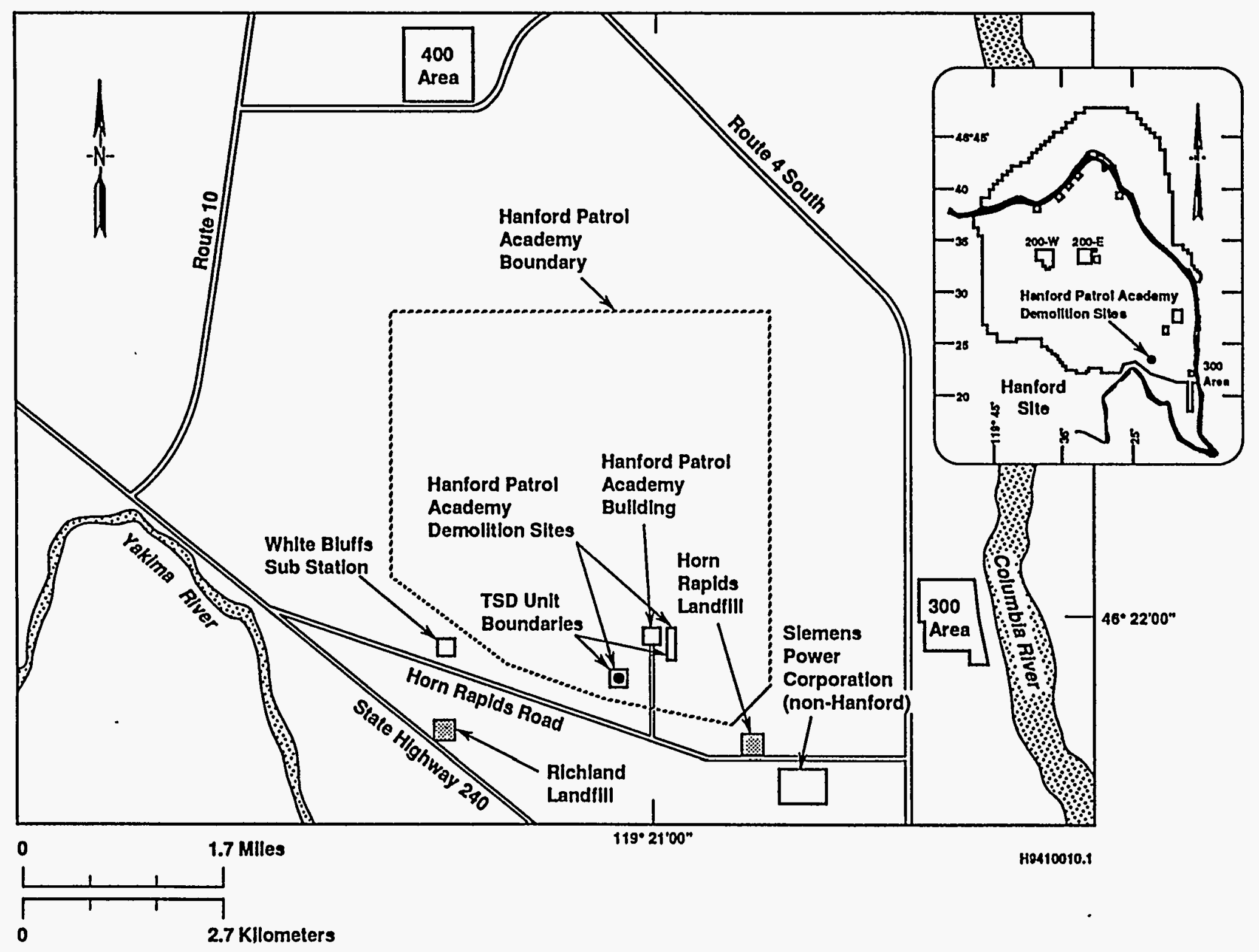


WA7890008967

\section{HANFORD PATROL ACADEMY DEMOLITION SITES}

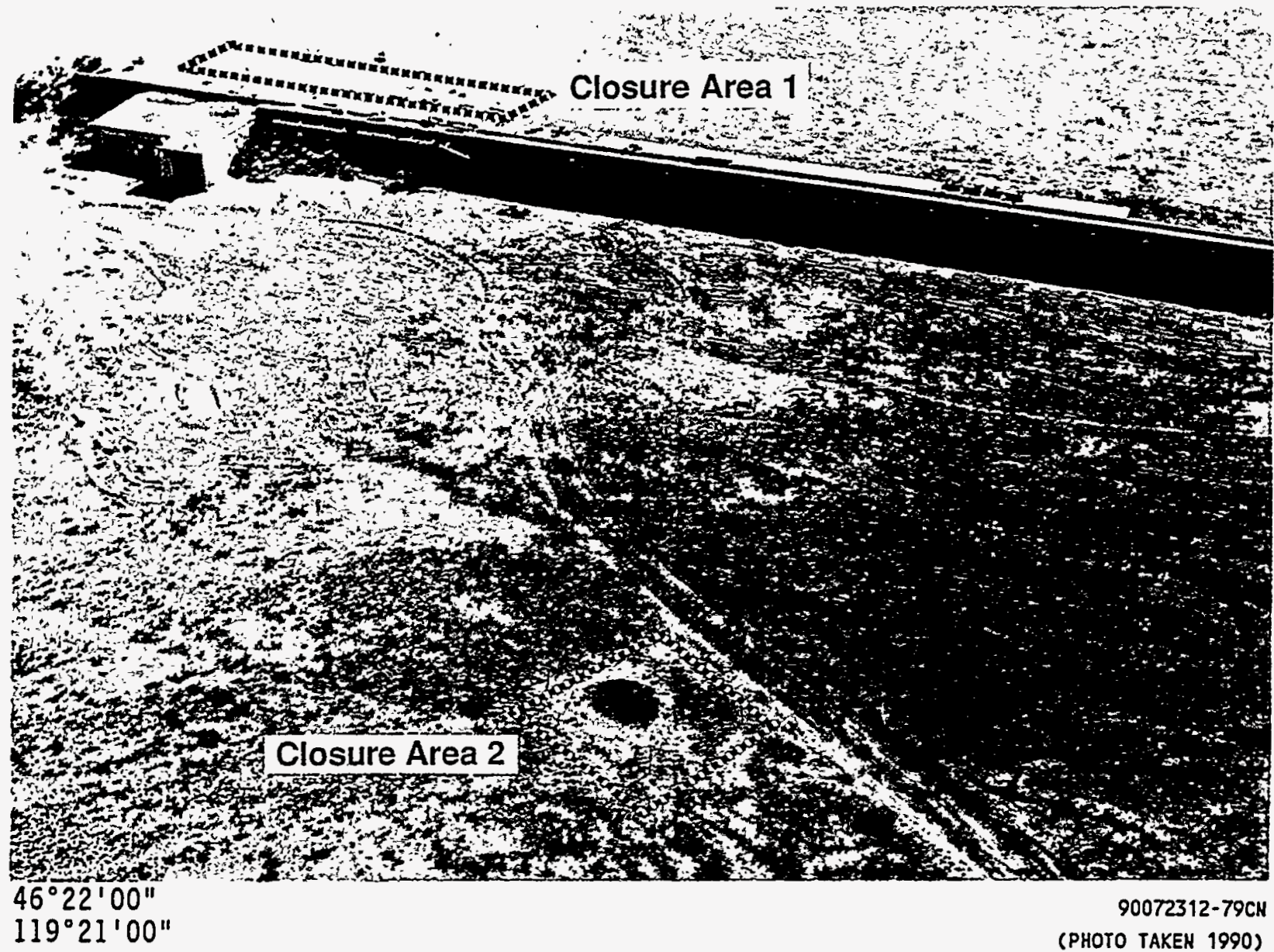




\section{DOE/RL-92-39, Rev. 1

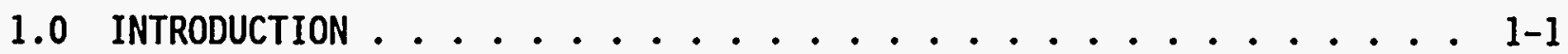

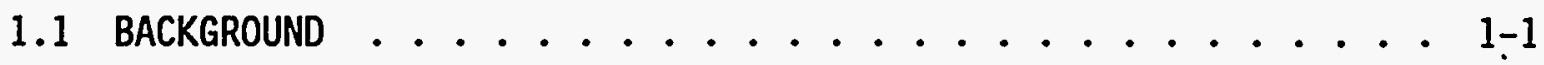

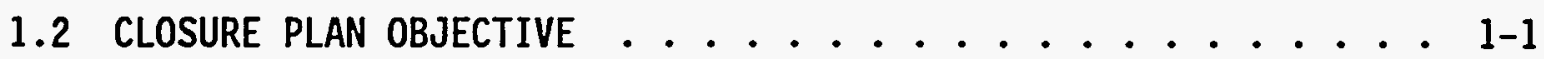

1.3 HANFORD PATROL ACADEMY DEMOLITION SITES CLOSURE

PLAN CONTENTS .................... 1-. . . . . .

1.3.1 Facility Description ............. 1-2

1.3.2 Process Information ............ 1-2

1.3.3 Waste Characteristics ............ 1-2

1.3.4 Groundwater Monitoring . . . . . . . . . . 1-2 1-3

1.3.5 Closure Performance Standards ........... 1-3

1.3.6 Closure Activities . . . . . . . . . . . 1-3

1.3 .7 Postclosure Plan .............. 1-. . . . .

1.3 .8 References ............... 1-3 


\section{DOE/RL-92-39, Rev. 1}

This page intentionally left blank. 


\subsection{INTRODUCTION}

This chapter provides background information for the Hanford Patrol Academy Demolition Sites (HPADS) and provides an overview of the contents of the HPADS closure plan.

\subsection{BACKGROUND}

From 1975 to 1991, the HPADS were used for demolition events. These demolition events were a form of thermal treatment for discarded explosive chemical products that were beyond their shelf 1 ife or no longer needed. Because the HPADS will no longer be used for this thermal activity, the sites will be closed. Closure will be conducted pursuant to the requirements of the Washington State Department of Ecology (Ecology) "Dangerous Waste Regulations", Washington Administrative Code (WAC) 173-303-610 and 40 Code of Federal Regulations (CFR) 270.1.

This closure plan presents a description of the HPADS, the history of the waste treated, and the approach that will be followed to close the HPADS. Because dangerous waste does not include the source, special nuclear, and by-product material components of mixed waste, radionuclides are not within the scope of WAC 173-303 or of this closure plan. The information on radionuclides is provided only for general knowledge where appropriate. Only dangerous constituents derived from HPADS operations wil1 be addressed in this closure plan in accordance with WAC 173-303-610(2)(b)(i).

The HPADS are two distinct closure areas within the Hanford Patrol Academy training area. Specifically, the two closure areas are within the Known Distance rifle range (KD range or No. 5 range).

The HPADS are not located within an operable unit; therefore, any contamination not associated with operation of the treatment, storage, and/or disposal (TSD) unit will be evaluated by the creation of a RCRA past practice solid waste management unit.

It is anticipated that the Hanford Patrol Academy and its training area (i.e., the firing range complex) wil1 be operated throughout the cleanup and postclosure monitoring period of the Hanford Federal Facility Agreement and Consent Order (Tri-Party Agreement) (Ecology et al. 1994), that is, to approximately the year 2050 .

\subsection{CLOSURE PLAN OBJECTIVE}

The objective of this closure plan is to support clean closure of the HPADS. Clean closure, as used in this context, means that no dangerous waste or dangerous waste contaminated soil will remain onsite to pose a threat to human health and the environment. To meet the criteria for clean closure of the HPADS, analytical results must verify that the levels of discarded explosive chemical products derived from HPADS operations are below action 


\section{levels. Action levels are defined as levels above the Hanford Site soil background levels identified in Hanford Site Background: Part 1, Soil Background for Nonradioactive Analytes (DOE-RL 1993) and Hodel Toxics Control Act (MTCA) (WAC 173-340) Method B- levels. If analysis determines that levels of the discarded explosive chemical products derived from the HPADS operations exceed these guidelines, a Phase II investigation will be developed.}

\subsection{HANFORD PATROL ACADEMY DEMOLITION SITES CLOSURE PLAN CONTENTS}

The HPADS closure plan consists of the following nine chapters.

- Introduction (Chapter 1.0)

- Facility Description (Chapter 2.0)

- Process Information (Chapter 3.0)

- Waste Characteristics (Chapter 4.0)

- Groundwater Monitoring (Chapter 5.0)

- Closure Performance Standards (Chapter 6.0)

- Closure Activities (Chapter 7.0)

- Postclosure P1an (Chapter 8.0)

- References (Chapter 9.0). sections.

A brief description of each chapter is provided in the following

\subsubsection{Facility Description (Chapter 2.0)}

This chapter provides a brief description of the Hanford Site and the location and description of the HPADS. Information on Hanford Site security also is provided.

\subsubsection{Process Information (Chapter 3.0)}

This chapter describes how the HPADS processed the waste and explains the overal1 waste treatment system.

\subsubsection{Waste Characteristics (Chapter 4.0)}

This chapter discusses the waste inventory and the characteristics of the waste that was treated at the HPADS.

\subsubsection{Groundwater Monitoring (Chapter 5.0)}

This chapter discusses the probability that groundwater contamination has not occurred and that groundwater monitoring is not needed. 


\subsubsection{Closure Performance Standards (Chapter 6.0)}

This chapter discusses the closure strategy, performance standards for protection of health and the environment, and closure activities.

\subsubsection{Closure Activities (Chapter 7.0)}

This chapter describes closure activities.

\subsubsection{Postclosure Plan (Chapter 8.0)}

This chapter outlines provisions for postclosure care, if required.

\subsubsection{References (Chapter 9.0)}

References used throughout this closure $\mathrm{plan}$ are listed in this chapter. All references listed here, which are not available from other sources, will be made available for review, upon request, to any regulatory agency or public commentor. References can be obtained by contacting the following:

Administrative Records Specialist

Public Access Room H6-08

Westinghouse Hanford Company

P.0. Box 1970

Richland, Washington 99352 
DOE/RL-92-39, Rev. 1

$12 / 15 / 94$

This page intentionally left blank. 


\section{CONTENTS}

2.0 FACILITY DESCRIPTION . . . . . . . . . . . . . 2-1

2.1 GENERAL HANFORD SITE DESCRIPTION .............. 2-1

2.2 FACILITY DESCRIPTION AND GENERAL PROVISIONS . . . . . . . 2-1

2.3 DESCRIPTION OF HANFORD PATROL ACADEMY DEMOLITION SITES . . . 2-2

2.4 SECURITY INFORMATION .................... 2-3

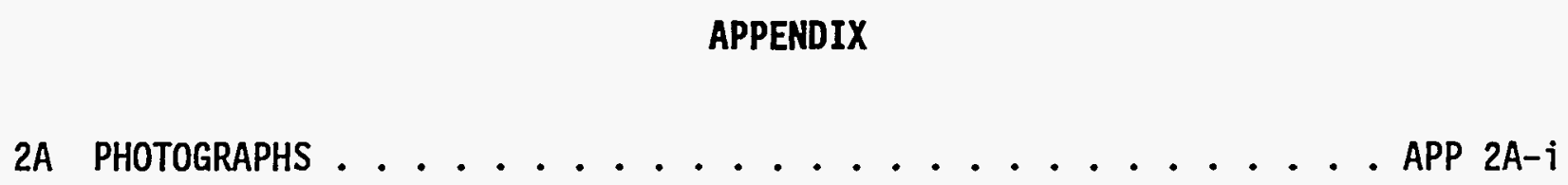

FIGURES

2-1. Hanford Site .................. F2-1

2-2. Hanford Patrol Academy Location . . . . . . . F2-2

2-3. Hanford Patro7 Academy Boundary . . . . . . . . . . . . . F2-3

2-4. Known Distance Range and Closure Area Details . . . . . . . . . F2-4

2-5. Hanford Patrol Academy Demolition Sites Closure Areas . . . . . . F2-5 
DOE/RL-92-39, Rev. 1

$12 / 15 / 94$

1
2
3
4
5

This page intentionally left blank. 
DOE/RL-92-39, Rev. 1

$12 / 15 / 94$

8

\subsection{FACILITY DESCRIPTION}

This chapter briefly describes the Hanford Site, the Hanford Facility, and the location of the HPADS, and provides information on Hanford Site security.

\subsection{GENERAL HANFORD SITE DESCRIPTION}

The Hanford Site covers approximately 560 square miles $(1,450$ square kilometers) of semiarid land that is owned by the U.S. Government and managed by the U.S. Department of Energy, Richland Operations Office (DOE-RL). The Hanford Site is located northwest of the city of Richland, Hashington (Figure 2-1). The city of Richland adjoins the southeasternmost portion of the Hanford Site boundary and is the nearest population center. In early 1943, the U.S. Army Corps of Engineers selected the Hanford Site as the location for reactor, chemical separation, and related activities for the production and purification of special nuclear materials and other nuclear activities. The mission of the Hanford Site recently has focused on waste management and environmental remediation and restoration.

Activities on the Hanford Site are centralized in numerically designated areas. The reactors are located along the Columbia River in the 100 Areas. The reactor fuel reprocessing units are in the 200 Areas, which are on a plateau approximately 7 miles (11 kilometers) from the Columbia River. The 300 Area, located adjacent to and north of Richland, contains the reactor fuel manufacturing plants and the research and development laboratories. The 400 Area, 5 miles ( 8 kilometers) northwest of the 300 Area, contains the Fast Flux Test Facility used for testing liquid metal reactor systems. Adjacent to and north of Richland, the 1100 Area contains offices associated with administration, maintenance, transportation, and materials procurement and distribution. The 3000 . Area, between the 1100 Area and 300 Area, contains engineering offices and administrative offices. Administrative offices also are located in the 700 Area, which is in downtown Richland. The 600 Area covers all locations not specifically given an area designation.

\subsection{FACILITY DESCRIPTION AND GENERAL PROVISIONS}

The Hanford Facility is a single Resource Conservation and Recovery Act (RCRA) facility identified by the U.S. Environmental Protection Agency (EPA)/State Identification Number WA7890008967 that consists of over 60 treatment, storage, and/or disposal (TSD) units conducting dangerous waste management activities. These TSD units are included in the Hanford Facility Dangerous Waste Part A Permit Application (DOE-RL 1988b). The Hanford Facility consists of a 11 contiguous land, and structures, other appurtenances, and improvements on the land, used for recycling, reusing, reclaiming, transferring, storing, testing, or disposing of dangerous waste, which, for the purposes of the RCRA, are owned by the U.S. Government and operated by the DOE-RL. 
DOE/RL-92-39, Rev. 1

$12 / 15 / 94$

\subsection{DESCRIPTION OF HANFORD PATROL ACADEMY DEMOLITION SITES}

The Hanford Patrol Academy is about 2 miles ( 3.2 kilometers) southsouthwest of the 300 Area and 0.5 mile $(0.8$ kilometer) north of the Horn Rapids Road, which is the northern boundary of the city of Richland, Washington (Figure 2-1).

The physical character of the Hanford Patrol Academy training area, including the TSD unit, is generally that of slightly sloped sand dunes. Vegetation has been removed from the firing range complex, including the TSD unit. This was necessary for fire prevention and safety reasons (e.g., bullet ricochets).

In the 1940's, the U.S. Army developed and used the six firing ranges that are now defined as the Hanford Patrol Academy Firing Range Complex. The DOE-RL allowed minimally controlled use of the firing ranges by non-Hanford personnel (e.g., the City of Richland Police Department and the Richland Rod and Gun (Tub), but ended that practice in 1982. After 1982, the DOE-RL began supervising use of the firing ranges by non-Hanford personnel. The TSD unit is on the KD firing range, separated by the concrete and earthen slope known as the 'target butt'. Figures 2-2 and 2-3 show the location of the Hanford Patrol Academy and the firing ranges. Figures 2-4 and 2-5 detail the location of the TSD unit.

During independent interviews of Hanford Site personnel, it was revealed that, in 1975, a metal canister of napalm $B^{1}$ was used as a rifle target during a training exercise. The napalm canister was shot repeatedly and failed to detonate. A subsequent attempt was made to ignite the canister with direct flame, which failed. The canister was then buried on one of the firing ranges, approximately 3 feet (1 meter) below surface. The specific location of the canister is unknown. It is believed that at the time of the training exercise, the gasoline was no longer in the gel matrix of the napalm or the canister may have been empty. Because this was not a RCRA activity, no further action is planned in association with this closure.

Since 1986, the firing range has been predominantly used for firearms training by the Hanford Patrol and, with the permission and supervision of the DOE-RL, the Richland Police Department and other personnel have used the range for the same purpose. It is planned that the Hanford Patrol will continue to use the firing range complex and, in particular, the $K D$ range, throughout the closure and postclosure monitoring phases of the Hanford Site's cleanup (through the year 2050). Also, it is anticipated that the KD range will continue to be available for selected Richland Police Department training purposes. However, detonation of discarded explosive chemical products that are beyond their shelf life or are determined to be excess will no longer occur at the HPADS.

${ }^{1} \mathrm{~A}$ full canister containing approximately 5 pounds (2.2 kilograms) of napalm $B$ would have been the size of a 1-pint or 1-quart container. 
The demolitions occurred within the KD range bullet impact area. Closure Area No. 1 is immediately south of the target butt at the change in slope (invert). Closure Area No. 2 is about 180 feet ( 55 meters) north of the target butt (Figure 2-4). Figure 2-5 shows the locations and physical dimensions of the closure areas.

The boundary for Closure Area No. 1 was determined by the combined judgment of personnel who witnessed the demolition events. Documentation of the boundaries of Closure Area No. 1 is unknown. Because the firing range has been repeatediy graded, any visible evidence of the detonations has been el iminated. Based on personnel interviews, the boundary of Closure Area No. 1 is on the south side of the KD range target butt and is 115 feet (35 meters) in length. The centerline is at the break in the slope between the mound of the target butt and the flat ground in front of the target butt and extends 16.4 feet ( 5 meters) Taterally (north and south) from the centerline, as shown in Figure 2-5.

In November 1984, detonation events were moved to behind the target butt (Closure Area No. 2) to minimize damage to Hanford Patrol Academy structures resulting from air blast. Closure Area No. 2 was physically demarcated before December 1989 [Hanford Patrol Firing Range Safety Assessment Document (WHC 1989b)] with four steel fence posts and wire that support closure area signs. As shown in Figure 2-4, Closure Area No. 2 is about 246 feet (75 meters) north of Closure Area No. 1 and 180 feet (55 meters) north of the target butt's concrete wall. As shown in Appendix $2 \mathrm{~A}$, the existing detonation pit is about 10 feet ( 3 meters) in diameter.

During the data quality objectives (DQO) process, all parties agreed top the recreated boundaries of Closure Area No. 1 and that Closure Area No. 2 has not changed position.

\subsection{SECURITY INFORMATION}

The entire Hanford Site is a controlled-access area. The Hanford Site maintains around-the-clock surveillance for the protection of government property, classified information, and special nuclear materials. The Hanford Patrol maintains a continuous presence of armed guards to provide Hanford Site security.

The training area is controlled by a locked gate. Access to the training area (which includes the HPADS closure areas) must be obtained from the Hanford Patrol Academy firing range safety officer. All personnel accessing these areas must have a U.S. Department of Energy-issued security identification badge indicating the appropriate authorization. Personnel also might be subject to a search of items carried into or out of these areas.

The closure areas have been roped off and delineated with warning signs to restrict personneT entry. The signs, stating "DANGER--UNAUTHORIZED PERSONNEL KEEP OUT" in English, are visible from all angles of approach, and are legible from a distance of at least 25 feet ( 7.6 meters). 
DOE/RL-92-39, Rev. 1

$12 / 15 / 94$

This page intentionally left blank. 


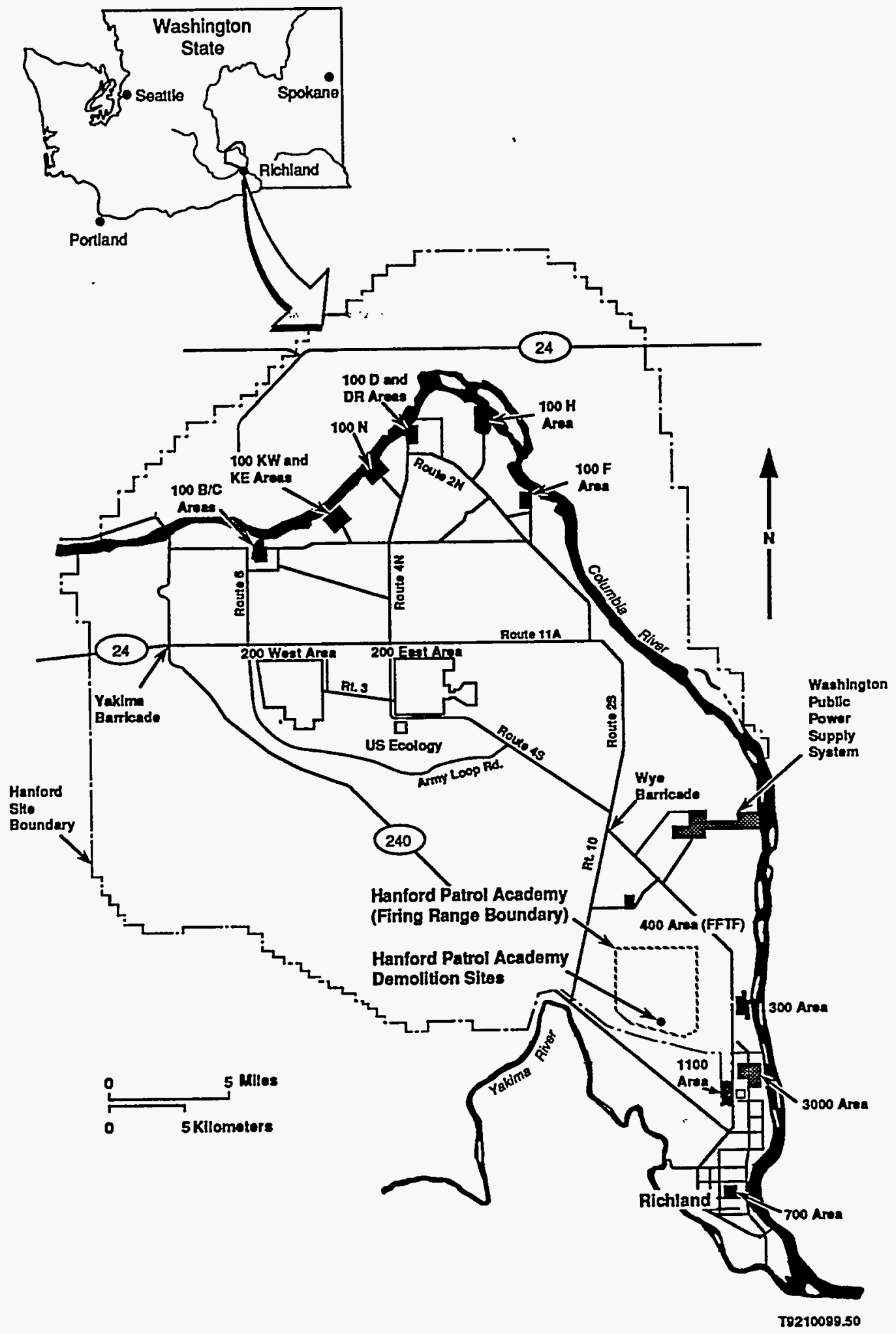

Figure 2-1. Hanford Site. 


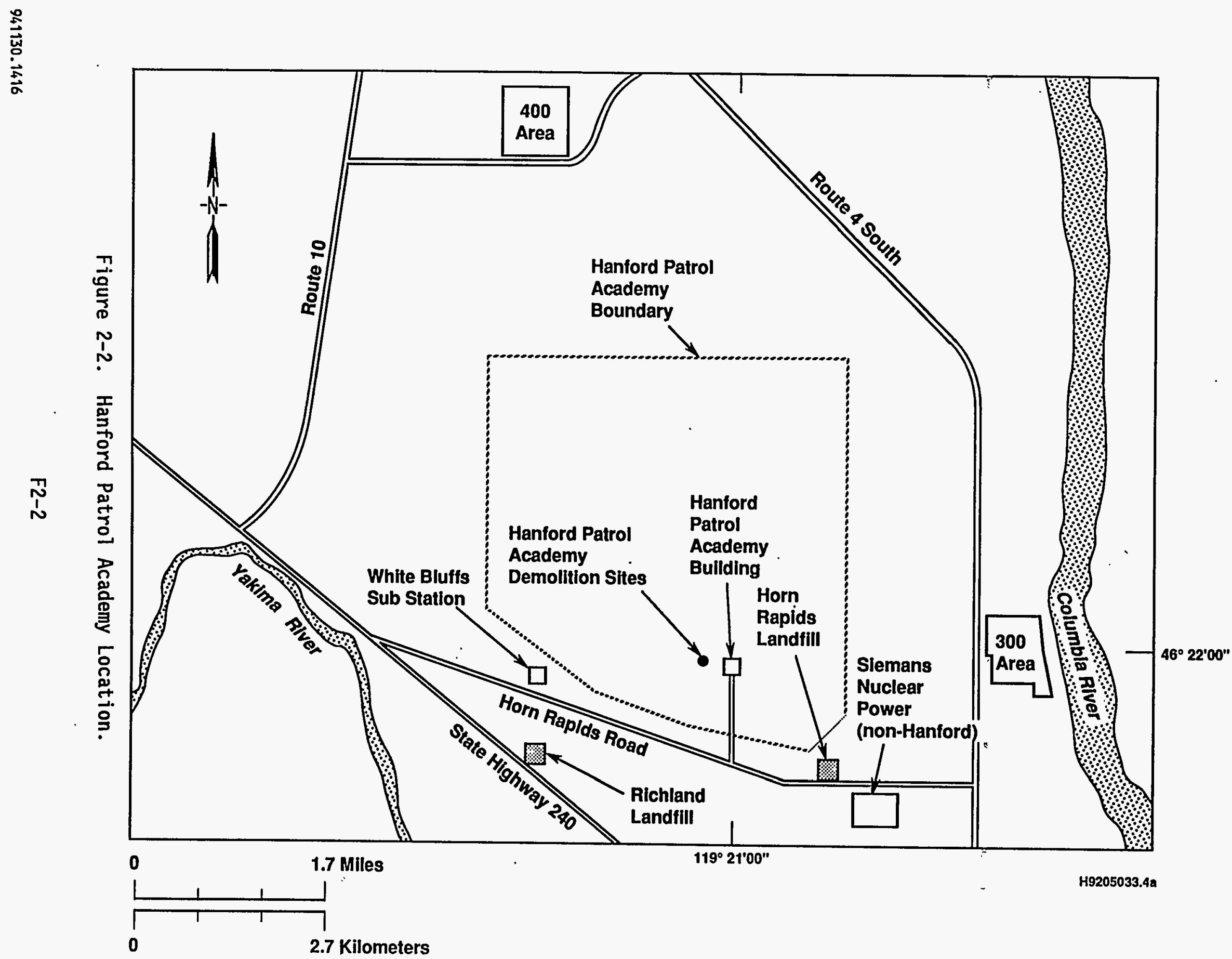

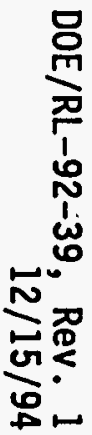




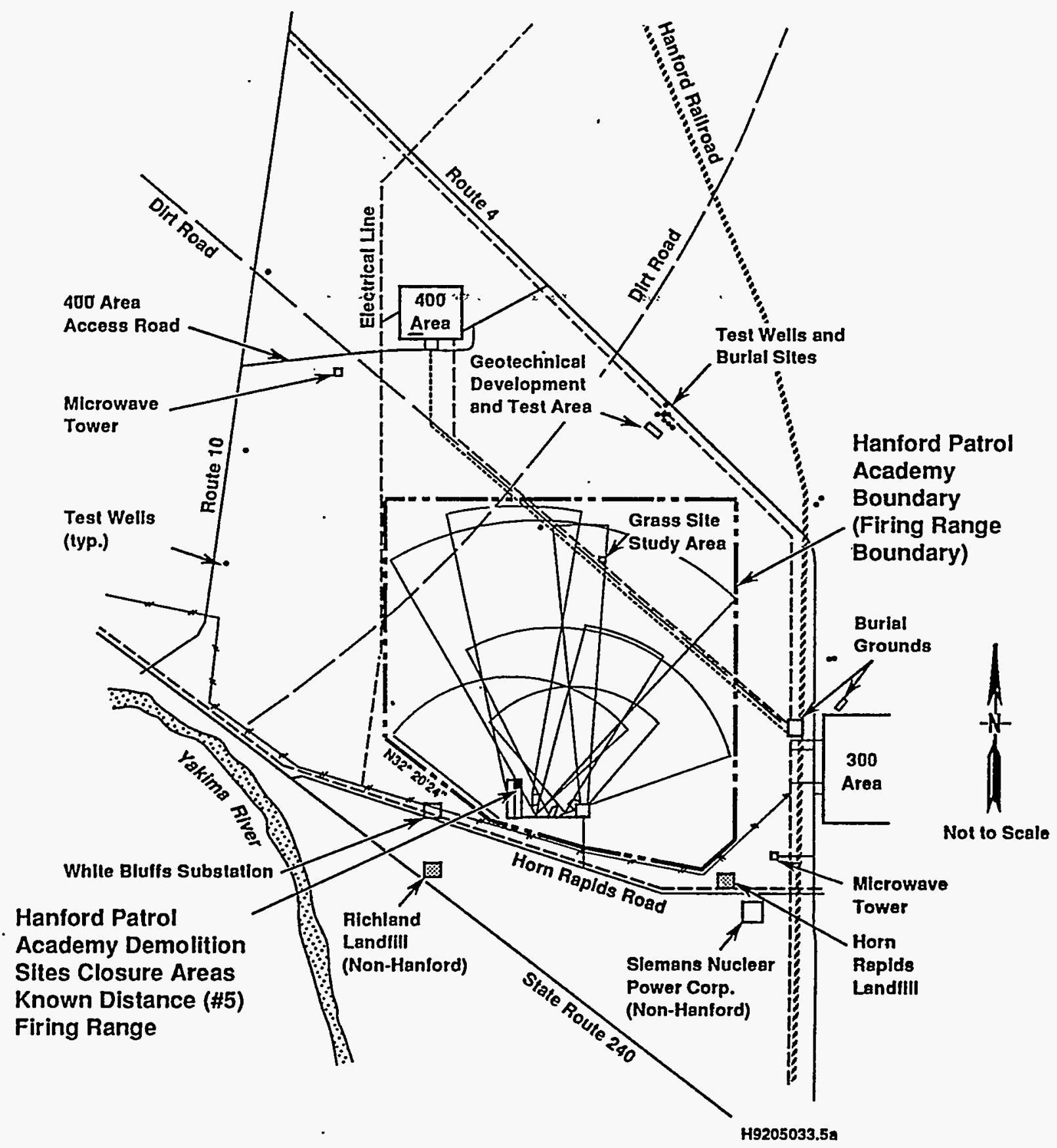

Figure 2-3. Hanford Patrol Academy Boundary. 


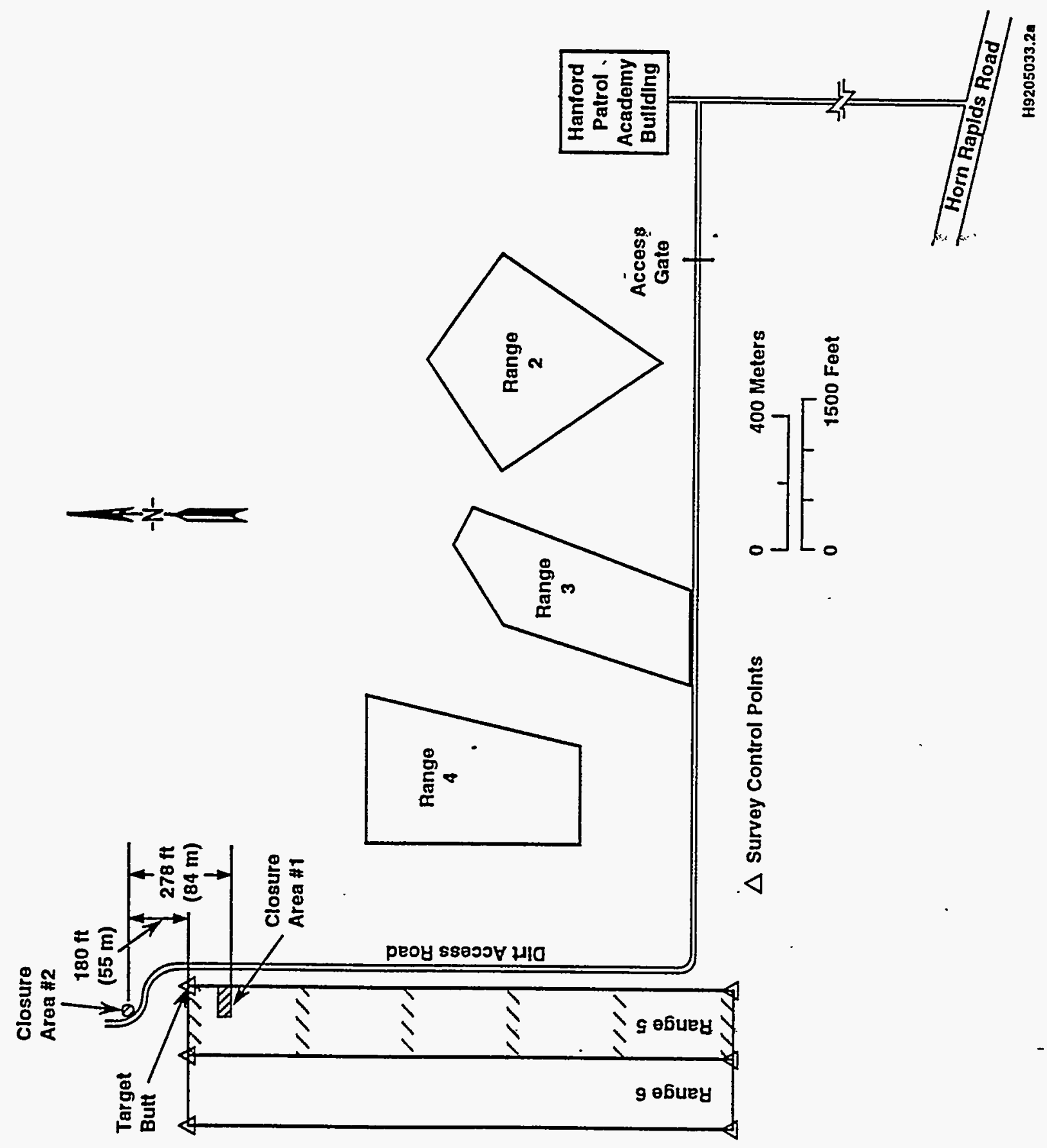

Figure 2-4. Known Distance Range and Closure Area Details. 


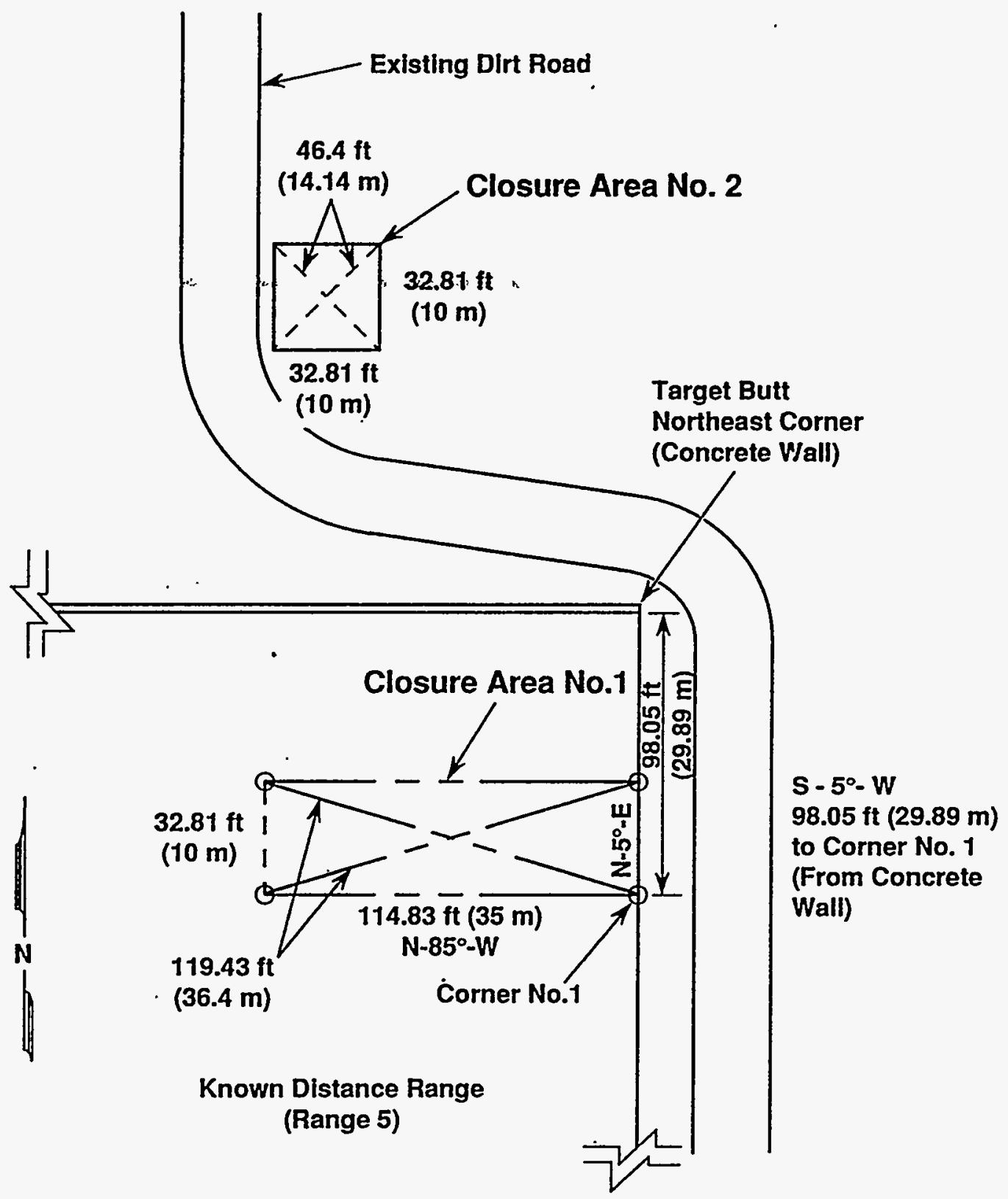

Based on Compass and Tape Survey of Field Conditions

(Not to Scale)

39210099.1

Figure 2-5. Hanford Patrol Academy Demolition Sites Closure Areas. 


\section{CONTENTS}

3.0 PROCESS INFORMATION ..................... 3-1

\section{APPENDICES}

$3 A$ SOIL SAMPLING INFORMATION FOR THE HANFORD PATROL ACADEMY DEMOLITION SITES MARCH 1987 DETONATION EVENT . ....... APP 3A-i

3B HANFORD WEATHER STATION METEOROLOGICAL DATA FOR HANFORD PATROL ACADEMY DEMOLITION SITES DETONATIONS OCCURRING

AFTER $1984 \ldots \ldots \ldots \ldots$. . . . . . . . . . . . . . . . . . . . 
DOE/RL-92-39, Rev. 1

$12 / 15 / 94$

This page intentionally left blank. 


\subsection{PROCESS INFORMATION}

Demolition of discarded explosive chemical products that were determined to be either excess or beyond designated shelf 1 ife was performed at the Hanford Patrol Academy Firing Range No. 5 from 1975 through October 27, 1991. In 1975, discarded explosive chemicals were detonated using M14 rifle fire to initiate the detonation of individual chemical containers. These containers were placed on the ground at the invert of Firing Range No. 5.

In October of 1984, onsite organizations started to document the removal from their inventory of any nonradioactive explosive, shock-sensitive, chemical products that exceeded the manufacturer's recommended shelf iife. Typically, solid waste engineering organizations would coordinate the transportation and demolition events. To minimize worker safety concerns and transportation hazards, similar demolition sites were established in the 200 Areas [218-E-8 Borrow Pit Closure Plan (DOE-RL 1994a) and 200 West Ash Pit Closure Plan (DOE-RL 1994b)].

Starting in 1984, the City of Richland Police Department Bomb Squad supplied commercial explosives and initiated the HPADS demolitions. The designated chemical containers were transported in the City of Richland's bomb trailer. Detonations in the HPADS closure areas occurred in specially hand-excavated holes to control air blast damage and to enhance the explosive effects of the demolition.

The discarded explosive chemical products were placed in the City of Richland Police Department bomb trailer after the day shift ended and transported to the HPADS. Hanford Patrol and Hanford Fire Department personnel provided escort vehicles [e.g., a lead Hanford Patrol vehicle with flashing lights, the bomb trailer and its tractor, the command vehicle, a fire truck, other vehicles (if involved), and a Hanford Patrol vehicle with lights flashing]. The Hanford Patrol Academy was cleared of nonessential personnel, and a safety zone was established. The demolition pit was prepared before arrival of the discarded explosive chemical products.

The usual detonation sequence was to place the containers into the pit. Then explosives were placed above and around the containers, and the explosives were 'wired-in'. Additional detonation cord sometimes was used to wrap specific, large-sized chemical containers to ensure better explosive efficiency. After the demolition personnel evacuated the blasting zone, the explosives were detonated with an electric blasting cap.

Following the detonation, onsite personnel would inspect the demolition pit and survey the area around the pit. When available, an organic vapor analyzer was used to determine that the discarded chemicals were consumed in the detonation. No records were kept of the post-detonation inspections. Immediately following the post-demolition inspection, the City of Richland Bomb Squad retrieved its electrical blasting line, other blasting equipment, and unused explosives. The demolition event was considered complete with the release of the Hanford Patrol Academy for routine activities. 


\footnotetext{
Periodically throughout the Hanford Patrol Academy Firing Range Complex, the vegetation was removed systematically to minimize potential brush fires and for other firing range safety precautions (e.g., ricochets). This practice also occurred at both of the closure areas and is depicted in Appendix 2A.

On October 30,1985 , a grass fire was ignited by a detonation, and immediately extinguished by the on-hand Hanford Fire Department personnel. The firing ranges and closure areas were graded (scarified) routinely to remove vegetation to reduce the potential for fire. Interviews with former demolition personnel revealed that on March 12, 1987, a demolition failure occurred. Following surveys with the organic vapor analyzer, an ether can remnant and ether-contaminated soil were placed in several 30-gallon (113.6-liter) containers and sent to an offsite TSD facility for disposal (Appendix 3A).

Meteorological data from the Hanford Weather Station is included in Appendix 3B for the detonation events that occurred after 1984.
} 
2

3

CONTENTS

4.0 WASTE CHARACTERISTICS ................. 4-1

4.1 ESTIMATE OF MAXIMUM INVENTORY OF WASTE . . . . . . . 4-1

4.2 WASTE TREATED AT THE HANFORD PATROL ACADEMY DEMOLITION SITES .................... 4-1

\section{APPENDIX}

4 A WASTE INVENTORIES ........................... 4 AP-i

\section{TABLES}

4-1. Dangerous Waste Treated at the Hanford Patrol Academy Demolition Sites ................... T4-1

4-2. Summary of Waste Treated at the Hanford Patrol Academy Demolition Sites ...................... T4-2

4-3. Physical Properties and MTCA Method B Cleanup Leveis for Discarded Chemical Products at the Hanford Patrol Academy Demolition Sites ............. . T4-3 
DOE/RL-92-39, Rev. 1 $12 / 15 / 94$

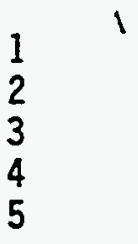

This page intentionally left blank. 


\subsection{WASTE CHARACTERISTICS}

This chapter addresses the waste inventory and waste treated at the HPADS.

\subsection{ESTIMATE OF MAXIMUM INVENTORY OF WASTE}

Chemicals treated at the HPADS (1984 to 1991) totaled approximately 570 pounds (260 kilograms) [Table 4-1 (references are located in Appendix 4A)]. The inventory consisted of nonradioactive discarded explosive chemical products, which were either totally consumed during the various detonations or rendered harmless by natural processes over time. The explosive, shock-sensitive, flammable, ignitible, and/or highly-reactive properties of the chemicals were used to bring about their chemical decomposition and/or destruction during detonation. The chemicals were rendered harmless to human health and the environment by the thermal characteristics of the explosions. Additionally, because of the volatility and instability of the chemicals under atmospheric conditions, even if the detonations were not 100 percent efficient, sufficient time would have passed since the last detonation for the natural processes of oxidation (through exposure to the atmosphere) and hydration (through exposure to water) to decompose the chemicals.

No records could be located to determine the type and quantity of detonation cord and electric blasting caps used to initiate the detonation events. Because of their explosive properties, these materials would not be expected to persist in the environment since the detonation events. Through the DQO process, the DOE-RL and regulators agreed that an analys is for detonation residues would verify the presence or absence of residues from these explosive initiators or accelerants.

\subsection{WASTE TREATED AT THE HANFORD PATROL ACADEMY DEMOLITION SITES}

Table 4-2 tabulates the waste designations per WAC 173-303-070.

Additional information concerning the waste detonated at the HPADS is located in Appendix 4A. Selection of chemicals for detonation generally was based on explosive, shock-sensitive, and/or flammable properties. Data presented in Table 4-3 indicate that all chemicals should have volatilized or decomposed during the detonation event or in the desert environment. The waste designations in Table 4-2 indicate that all of the waste was ignitible and reactive.

Table 4-3 also contains information on available MTCA Method B cleanup levels for involved constituents. 
DOE/RL-92-39, Rev. 1

$12 / 15 / 94$

1
2
3
4
5

This page intentionally left blank. 
Table 4-1. Dangerous Waste Treated at the Hanford Patrol Academy Demolition Sites. (sheet 1 of 4 )

CLOSURE AREA NO. 1

\begin{tabular}{|c|c|c|c|c|}
\hline Chemical & Amount (kg) & $\begin{array}{c}\text { Container } \\
\text { number/size }\end{array}$ & $\begin{array}{c}\text { Detonation } \\
\text { date }\end{array}$ & Reference ${ }^{1}$ \\
\hline Ethyl Ether & 11.40 & $25 \times 1 \mathrm{pt}$ & 16-Aug-84 & PNL-84-004 \\
\hline Tetrahiydrofuran & 5.82 & $6 \times 1$ qt. & $16-A u g-84:$ & PNE-84-037. \\
\hline Perchloric Acid & 3.12 & $8 \times 1$ pt. & $16-$ Aug- 84 & PHL-83-020 \\
\hline 2-Butoxyethanol & 3.96 & & $16-\operatorname{Aug}-84$ & PHL-83-014 \\
\hline
\end{tabular}

CLOSURE AREA NO. 2

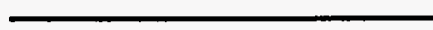

Chemical

Amount (kg)

Container

Ethyl Ether

0.41

number/size

.48 .18

Detonation

date

Originah

Nov-84 RHO 1167

0.50

2,4-D ini trophenythydrazine

0.13

$\alpha$-Nitrosomethyl Isobutyl Ketone

0.17

Butyl Ethanol

7.00

9.80

Carbon Disulfide

3.80

Ethyl Ether

0.80

Glycol Dimethyl Ether

0.07

17.30

Perchloric Acid.

0.10

Picric Acid

0.30

49.70

Picryl Chloride

0.10

0.19

0.50

0.48

37 Tetrahydrofuran

0.30

Perchloric Acid

\begin{tabular}{|c|c|c|}
\hline 30 -oct-85 & PHL & 3714 \\
\hline 30 -Oct-85 & PHL & 3714 \\
\hline $30-0 c t-85$ & PHL & 3714 \\
\hline $30-0 c t-85$ & PHL & 3714 \\
\hline $30-$ oct-85 & PHL & 3714 \\
\hline $30-0 c t-85$ & PHL & 306E \\
\hline $30-0 c t-85$ & PHL & 332 \\
\hline $30-0 c t-85$ & PHL & sian 5 \\
\hline $30-0 c t-85$ & PML & 332 \\
\hline $30-$ oct-85 & PHL & 3714 \\
\hline $30-0 c t-85$ & PHL & LSL 11 \\
\hline $30-0 c t-85$ & PHL & 3714 \\
\hline $30-0 c t-85$ & PHL & 3714 \\
\hline $30-0 c t-85$ & PHL & SIGH 5 \\
\hline $30-0 c t-85$ & PHL & 3714 \\
\hline $30-0 c t-85$ & UNC & $100 \mathrm{~N}$ Area \\
\hline $30-$ oct-85 & PNL & 332 \\
\hline $30-$ oct -85 & PNL & 332 \\
\hline $30-0 c t-85$ & PHL & 332 \\
\hline
\end{tabular}


Table 4-1. Dangerous Waste Treated at the Hanford Patrol Academy Demolition Sites. (sheet 2 of 4 )

CLOSURE AREA NO. 2

\begin{tabular}{|c|c|c|c|c|c|}
\hline Chemical & Amount (kg) & $\begin{array}{c}\text { Container } \\
\text { number/size }\end{array}$ & $\begin{array}{c}\text { Detonation } \\
\text { date }\end{array}$ & Reference $^{9}$ & $\begin{array}{l}\text { Originah } \\
\text { location }\end{array}$ \\
\hline Ethyl Ether & 12.00 & 1-gal & 12-Mar-87 & HHC & 329 \\
\hline Isopropyl Eth́er & 4.00 & $i=p t$ & $12-$ Mar-87 & PNL $\cdots$ & $33 t^{\prime}$ \\
\hline Picric Acid & 0.20 & 1-pt & $12-M a r-87$ & PHL & 331 \\
\hline Ethyl Ether & 4.00 & 1-pt & $12-\operatorname{Mar}-87$ & PML & 331 \\
\hline $\begin{array}{l}\text { Borontrifluoride Ether } \\
\text { Complex }\end{array}$ & 0.40 & 1 & $25-$ Aug-87 & PHL 22-129 & 332 \\
\hline 1,4-Dioxane & 0.50 & 1 & $25-$ Aug- 87 & PHL & 332 \\
\hline Tetrahydrofuran & 0.10 & 1 & $25-A u g-87$ & PHL & 332 \\
\hline Hydrazine Monohydrate & 0.50 & 1 & 25-Aug-87 & PHL & 332 \\
\hline $\begin{array}{l}\text { Borontrifluoride Methanol } \\
\text { Complex }\end{array}$ & 1.00 & 1 & 25-Aug-87 & PHL & 332 \\
\hline $\begin{array}{l}\text { Butyllithium/Benzene } \\
\text { Mixture }(1: 3)\end{array}$ & 0.20 & 1 & $25-A u g-87$ & PHL 22-125 & 332 \\
\hline $\begin{array}{l}\text { Borontrifluoride/Methanol } \\
\text { Mixture }(14: 86)\end{array}$ & 0.05 & 1 & 25-Aug-87 & PML & 332 \\
\hline $\begin{array}{l}\text { Borontrifluoride Ether } \\
\text { Complex }\end{array}$ & 0.10 & 1 & $25-$ Aug- 87 & PHL & 332 \\
\hline 2,4-D ini trophyenlhydrazine & 0.03 & 1 & 25-Aug-87 & PML & 332 \\
\hline Allyl Ether (100\%) & .0005 & 1 & 25-Aug-87 & PNL & 332 \\
\hline Triethyl Aluminum & 0.30 & 1 & 25-Aug-87 & PNL 22-114 & 332 \\
\hline Naphthacene & 0.003 & 1 & 25-Aug-87 & PML & 332 \\
\hline 2-Methyl furan (100\%) & .0005 & 1 & 25-Aug-87 & PNL & 332 \\
\hline Tetrahydrofuran & 3.80 & 1 & 25-Aug-87 & PNL 22-125 & 331 \\
\hline 1,4 Dioxane & 1.00 & 1 & 25-Aug-87 & PNL & 331 \\
\hline Perchloric Acid & 0.14 & & 09-Dec-87 & UNC & 100H Area \\
\hline Magnesium Perchlorate & 0.50 & & $09-$ Dec-87 & PHL & 332 \\
\hline Tetrahydrofuran & 0.48 & & 09-Dec-87 & PML & 332 \\
\hline Perchloric Acid & 0.30 & & $09-$ Dec-87 & PHL & 332 \\
\hline Trinitrololuene & 0.10 & & $09-$ Dec-87 & PHL & 3714 \\
\hline Picric Acid & 0.20 & & $09-$ Dec-87 & PHL & 3714 \\
\hline 1,4 Dioxane & 2.59 & & $21-J u n-88$ & WHC & 100K Area \\
\hline Ethyl Ether & 2.14 & & 21-Jun-88 & PHL & 332 \\
\hline
\end{tabular}


Table 4-1. Dangerous Waste Treated at the Hanford Patrol Academy Demolition Sites. (sheet 3 of 4)

1
CLOSURE AREA NO. 2

\begin{tabular}{|c|c|c|c|c|c|}
\hline Chenical & Amount $(\mathrm{kg})$ & $\begin{array}{c}\text { Container } \\
\text { number/size }\end{array}$ & $\begin{array}{c}\text { Detonation } \\
\text { date }\end{array}$ & Reference ${ }^{1}$ & $\begin{array}{l}\text { Original } \\
\text { location }\end{array}$ \\
\hline Perchloric Acid & 0.13 & & $21-J u n-88$ & PNL & 332 \\
\hline Ethyl Ether & 0.25 & & 21-Jün-88 & PHL & 352 \\
\hline Picryl chloride & $\overline{0} .08$ & & $21-J u n-88$ & PHL & 332 \\
\hline Picric Acid & 0.62 & & $21-J u n-88$ & PHL & 332 \\
\hline Lithium Triethylborohydride & 0.90 & & $20-$ Dec-88 & PHL-24-556 & 332 \\
\hline Ethyl Ether & 1.50 & & $20-$ Dec- 88 & PNL-24-737 & 332 \\
\hline Ethyl Ether & 10.80 & & 20-Dec-88 & PHL & 332 \\
\hline $\begin{array}{l}2,2 !, 4,41,6,61-\text { Hexani trodi- } \\
\text { phenylamine }\end{array}$ & 0.05 & & 20-DeC-88 & PHL & 332 \\
\hline Picryl Chloride & 0.03 & & 20-Dec-88 & PNL-24-764 & 332 \\
\hline 1,4-Dioxane & 0.50 & & $20-$ Dec-88 & PHL-24-764 & 332 \\
\hline 2,4-D ini trophyenthydrazine & 0.11 & & 10-Feb-89 & NOME & 331 \\
\hline Tetrahydrofuran & 1.00 & & 02-Mar-89 & PNL-24-878 & 332 \\
\hline Hydrazine Monohydrate & 0.80 & & 02-Mar-89 & PHL-25-054 & 332 \\
\hline 2,4-D initrophyenthydrazine & 0.20 & & 02-Mar-89 & PNL-25- 114 & 331 \\
\hline Perchloric Acid & 7.00 & & 02-Mar-89 & PHL-25-114 & 331 \\
\hline Ethyl Ether, anhydrous & 1.00 & & $02-$ Mar-89 & PNL-25- 114 & 331 \\
\hline Benzoyl Peroxide & 0.45 & & 02-Mar-89 & PNL-25-114 & 331 \\
\hline Tetrahydrofuran & 7.60 & & 02-Mar-89 & PNL-25-114 & 331 \\
\hline 1,4-D ioxane & 3.00 & & $02-$ Mar-89 & PNL-25-114 & 331 \\
\hline $\begin{array}{l}2,4,6,21,6 \text {-Hexani trodi- } \\
\text { phenylamine }\end{array}$ & 0.20 & & $02-M a r-89$ & PNL-25-114 & 331 \\
\hline Picryl Chloride & 0.06 & $1-4$ oz & $26-A p r-89$ & PHL-25-209 & 332 \\
\hline 1,4 Dioxane & 5.45 & 11-pt. & $26-A p r-89$ & PHL-25-209 & 332 \\
\hline P-Dioxane & 1.00 & $1-1 / 2 \mathrm{gol}$ & $26-A p r-89$ & PHL-25-209 & 332 \\
\hline Tetrahydrofuran & 3.80 & 1-gal & 26-Apr-89 & PML-25-209 & 332 \\
\hline $\begin{array}{l}\text { Hitrocel lulose/Isopropyl } \\
\text { Alcohol }\end{array}$ & 2.00 & 2-pt & 26-Apr-89 & PNL-25-209 & 332 \\
\hline n-Butyl Ether & 0.50 & $1-q t$ & 26-Apr-89 & PHL-25-209 & 332 \\
\hline
\end{tabular}


Table 4-1. Dangerous Waste Treated at the Hanford Patrol Academy Demolition Sites. (sheet 4 of 4 )

1

CLOSURE AREA NO. 2

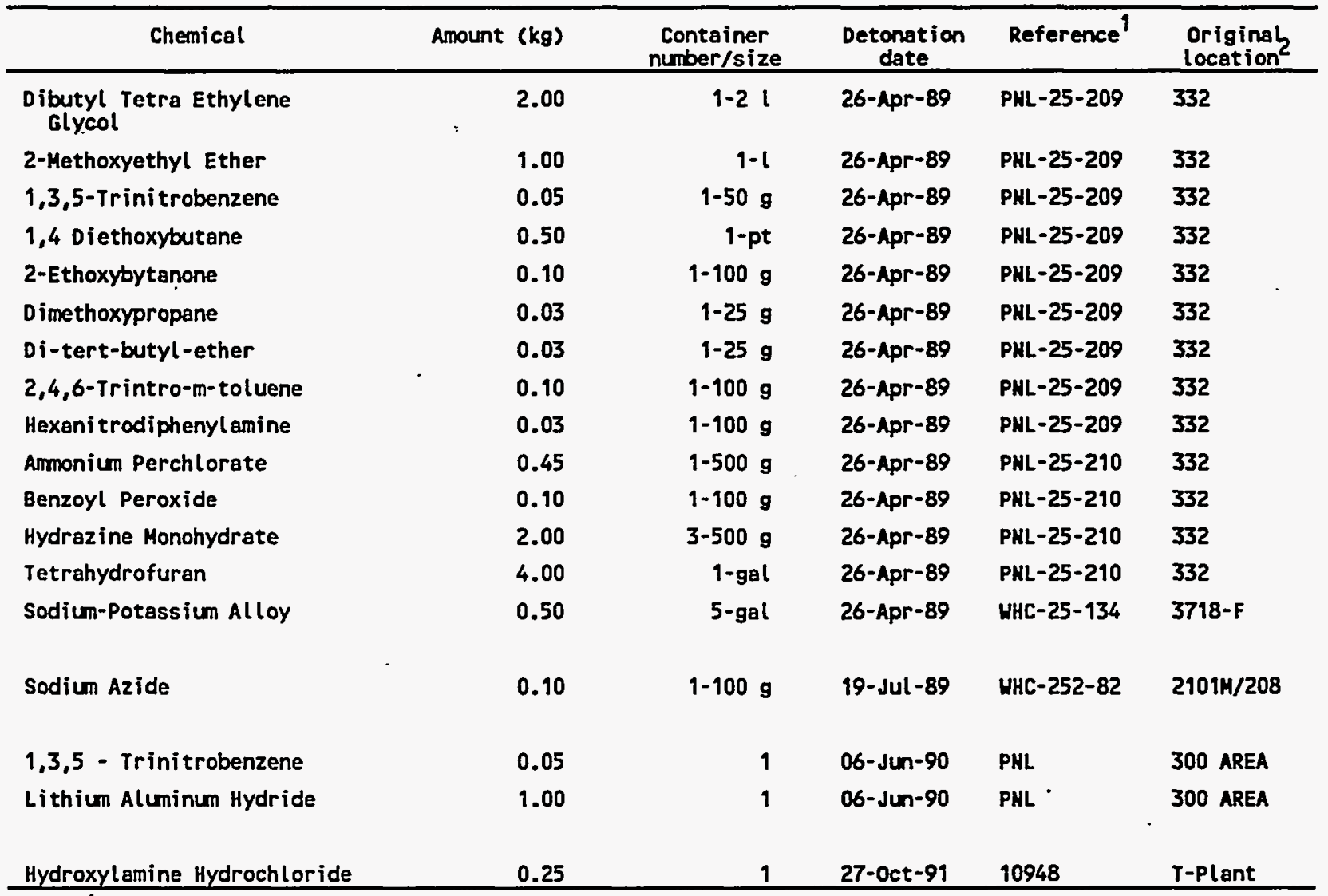

${ }_{2}^{1}$ isposal request letter (Appendix 4A).

Building number unless otherwise noted.

PNL = Pacific Northwest Laboratories.

RHO $=$ Rockwel $l$ Hanford Operations.

UNC = United Nuclear Company.

WHC = Westinghouse Hanford Company. 
Table 4-2. Summary of Waste Treated at the Hanford Patrol Academy Demolition Sites. (sheet 1 of 2)

\begin{tabular}{|c|c|c|c|}
\hline 3 & Chemical identification & Quantity $(\mathrm{kg})$ & $\begin{array}{c}\text { Complete waste } \\
\text { designation } \\
(40 \text { CFR 261, } \\
\text { WAC 173-303) } \\
\end{array}$ \\
\hline 4 & Closure Area No. 1 & & \\
\hline 5 & 2-Butoxyethariol. & 3.96 & D001, D003, WTO2. \\
\hline 6 & Ethyl ether & 11.40 & D001, D003, U117, WTO2 \\
\hline 7 & Perchloric acid & 3.12 & D001, D002, D003, WTO2 \\
\hline 8 & Tetrahydrofuran & 5.82 & D001, D003, U213, WTO2 \\
\hline 9 & Subtotal & 24.29 & \\
\hline 10 & Closure Area No. 2 & & \\
\hline 11 & Allyl ether & 0.0005 & D001, D003, WTO1 \\
\hline 12 & Ammonium perchlorate & 0.45 & D001, D003, WTO2 \\
\hline 13 & Benzoyl peroxide & 0.55 & D001, D003 \\
\hline 14 & Boron trifluoride ether complex & 0.50 & D001, D002, D003, WPO1 \\
\hline $\begin{array}{l}15 \\
16\end{array}$ & $\begin{array}{l}\text { Boron trifluoride methanol } \\
\text { complex }\end{array}$ & 1.05 & $\begin{array}{l}\text { D001, D002, D003, WPO1, } \\
\text { WT02 }\end{array}$ \\
\hline $\begin{array}{l}17 \\
18\end{array}$ & $\begin{array}{l}\text { Butyl ethanol; } \\
\text { syn. 2-hexanol }\end{array}$ & 7.00 & D001, D003 \\
\hline 19 & n-butyl ether & 0.52 & D001, D003, WTO2 \\
\hline $\begin{array}{l}20 \\
21\end{array}$ & $\begin{array}{l}\text { Buty } 11 \text { ithium/benzene mixture } \\
(1: 3)\end{array}$ & 0.20 & $\begin{array}{l}\text { D001, D003, D018, WCO2, } \\
\text { WT01 }\end{array}$ \\
\hline 22 & Carbon disulfide & 9.80 & D001, D002, P022, WT02 \\
\hline 23 & Dibutyl tetraethylene glycol & 2.00 & D001, D003 \\
\hline 24 & 1,4-Diethoxybutane & 0.50 & $\mathrm{D} 001, \mathrm{D} 003$ \\
\hline 25 & 2,2-Dimethoxypropane & 0.025 & D001, D003 \\
\hline 26 & 2,4-Dinitrophenol & 0.50 & D001, D003, P048, WTO2 \\
\hline 27 & 2,4-Dinitrophenylhydrazine & 0.46 & D001, D003 \\
\hline 28 & 2,4-Dinitroresorcino 1 & 0.07 & D001, D003 \\
\hline 29 & 1,4,-Dioxane (syn. p-Dioxane) & 14.04 & $\begin{array}{l}\text { D001, D003, U108, WCO1, } \\
\text { WT02 }\end{array}$ \\
\hline 30 & 2-Ethoxybutanone & 0.10 & $D 001, D 003$ \\
\hline 31 & (Ethylene) Glycol dimethyl ether & 0.80 & $\mathrm{D} 001, \mathrm{D} 003$ \\
\hline 32 & Ethyl ether & 35.89 & D001, D003, U117, WTO2 \\
\hline
\end{tabular}


Table 4-2. Summary of Haste Treated at the Hanford Patrol Academy Demolition Sites. (sheet 2 of 2)

\begin{tabular}{lcc}
\hline & $\cdot$ & Complete waste \\
designation & \\
Chemical identification & Quantity $(\mathrm{kg})$ & CFR 261, \\
& & WAC 173-303) \\
\hline
\end{tabular}

1 Hexanitrodiphenylamine

2 Hydrazine monohydrate

3 Hydroxylamine hydrochloride

4 Isopropyl ether

5 Lithium aluminum hydride

$6 \quad$ Lithium triethylborohydride

7 Magnesium perchlorate

8 2-Methoxyethyl ether

9 2-Methylfuran

10 Napthacene

11 Nitrocellulose/isopropyl alcohol

12 A-Nitrosomethyl isobuty] ketone

13 Perchloric acid

14 Picric acid

15 Picryl chloride

16 Sodium azide

17 Sodium-potassium alloy

18 Tetrahydrofuran

19 Triethylaluminum in toluene

20 1,3,5-Trinitrobenzene

21 2,4,6-Trinitroresorcinol

22 2,4,6-Trinitrotoluene

23

24

25

26$$
5
$$

\subsection{4}

3.30

0.25

4.00

1.00

0.90

1.00

1.00

0.0005

0.003

$<2$

0.17

73.54

1.12

0.46

0.10

0.50

70.96

0.30

0.10

0.025

0.30

Subtotal

235.84

Total waste treated
D001, D003

$D 001, D 002$, , D003, U. U133, WCO2

D001, D003

D001, D003, WTO2

D001, D002, D003

D001, D002, D003

D001, D003

D001, D003

D001, D003, WT01

WPO3

D001, D003

D001, D003

D001, D002, D003, WTO2

D001, D002, D003

D001, D003

D001, D002, P105, WTO2

$D 001, D 002, D 003$

D001, D003, U213, WTO2

D001, D003

D001, D003, U234, WT02

D001, D003

D001, D003, WTO2

\begin{tabular}{lll}
\hline Subtotal & 235.84 \\
\hline
\end{tabular}

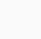


Table 4-3. Physical Properties and MTCA Method B Cleanup Levels for Discarded Chemical Products at the Hanford Patrol Academy Demolition Sites. (sheet 1 of 3).

\begin{tabular}{|c|c|c|c|c|c|c|c|c|c|c|c|c|c|}
\hline $\begin{array}{l}\text { Wasto Idontity, Quantt } \\
\text { Chemical Identification }\end{array}$ & $\begin{array}{l}\text { and } \\
\text { Quantity } \\
(k g)\end{array}$ & $\begin{array}{l}\text { Indexes } \\
\text { Merck } \\
\text { Number }\end{array}$ & \begin{tabular}{c|} 
C.A.S.t \\
Number
\end{tabular} & $\mid \begin{array}{c}\text { Physical } \\
\text { Phys. } \\
\text { Staie } \\
\text { at STP }\end{array}$ & $\begin{array}{l}\text { Prop } \\
\text { Flash } \\
\text { Point } \\
\left({ }^{\circ} \mathrm{C}\right) \\
\end{array}$ & $\begin{array}{l}\text { Specifle } \\
\text { Gravity }\end{array}$ & $\begin{array}{c}\text { Polting } \\
\text { Point } \\
\left({ }^{\circ} \mathrm{C}\right) \\
\end{array}$ & $\left|\begin{array}{c}\text { Vapor } \\
\text { Pressure } \\
\text { (mm Hg) }\end{array}\right|$ & Misctt & $\begin{array}{c}\begin{array}{c}\text { Oral } \\
\text { Chronic RID } \\
(\mathrm{kg} \cdot \mathrm{d}) / \mathrm{mg}\end{array} \\
\end{array}$ & $\begin{array}{c}\text { Cancer } \\
\text { Slope Factor } \\
\left(\mathrm{kg}^{*} \mathrm{~d}\right) / \mathrm{mg} \\
\end{array}$ & $\begin{array}{r}\text { MTCA-Method B So } \\
\text { Clean-Up Levels } \\
\text { Non-Cancer }\end{array}$ & Cancer \\
\hline Allyl Ether & 0.0005 & 290 & $557-40-4$ & llauid & -6 & 0.805 & & & of $\mathrm{tx}$ & & & & \\
\hline Ammonium Perchlorate & 0.450 & 568 & $7790-98-9$ & solid & 350 & 1.950 & 130 & & II, ss & & & & \\
\hline Benzoyl Peroxide & 0.550 & 1128 & $94-36-0$ & solid & 68 & 1.334 & 106 & $<1$ & $e x, 1 x$ & & & & \\
\hline Boron Trifluoride Elher complex & 0.500 & 1352 & $109-63-7$ & Ilquid & 63.8 & 1.154 & -60 & 45 & fl, $\mathrm{ms}$ & & & & \\
\hline Boron Trilluoride Methanol cmplx & 1.050 & & $373-57-9$ & liquid & 11 & 1.203 & $<38$ & & II & & & & \\
\hline 2-Butoxyethanol & 3.955 & 1559 & $111 \cdot 76-2$ & liquid & 60 & 0.902 & -94 & 0.76 & 11 & & & & \\
\hline | Butyl Ethanol: syn. 2-hexanol & 7.000 & & $626-93-7$ & Iliquild & 41 & 0.810 & & & com & & & & \\
\hline n-butyl ether & 0.525 & 1568 & $142-96-1$ & Ilquid & 25 & 0.764 & -98 & 4.8 & 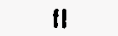 & & & & \\
\hline Buryllithlum/Benzene mix. (25:75) & 0.200 & & & & & & & & & & & & \\
\hline Butyllihhlum (in cyclohexane) & & & $598-30-1$ & liquld & -17 & 0.769 & & & pyr, ms & & & & \\
\hline Benzene & & 1074 & $71-43-2$ & liquld & -11 & 0.877 & 6 & 75 & $e x,|x, i|$ & & $2.90 \mathrm{E}-02$ & & $3.40 E+01$ \\
\hline Carton Disullide & 9.800 & 1818 & $75-15-0$ & Hquild & -30 & 1.266 & -111 & & II, $t x$ & $1.00 E+01$ & & $8.00 E+03$ & \\
\hline Dibutyl Tetraethylene Glycol & 2.000 & & & & & & & & & & & & \\
\hline 1.4-Dlethoxybutane & 0.500 & & & & & & & & & & & r & \\
\hline 2,2-Dimethoxypropane & 0.025 & & $77-76-9$ & Ilquild & -11 & 0.847 & -47 & 74 & $\theta \mathbf{x}$ & & & & \\
\hline 2,4-Dinitrophenol & 0.500 & 3274 & $51-28-5$ & solid & $\theta x$ & 1.683 & 115 & & $\theta x, \mid x, \|$ & $2.00 \mathrm{E}-03$ & & $1.60 E+02$ & \\
\hline 2,4-Dinitrophenylhydrazine & 0.463 & 3277 & $119-26-6$ & solld & 209 & & 194 & dec & $\|_{1} \theta x$ & & & & \\
\hline 2,4-DInitroresorclnol & 0.070 & 3278 & $519-44-8$ & solid & $\theta x$ & & 146 & & ex, hs & & & & \\
\hline $\begin{array}{l}\text { 1,4,-Dloxane; syn. p-Dloxane } \\
\text { 2-Ethoxybutanone }\end{array}$ & $\begin{array}{r}14.040 \\
0.100\end{array}$ & 3294 & $\mid 23-81-1$ & liquild & 12 & 1.036 & 12 & 27 & II, $1 x$ & & 1.10E-02 & & $9.10 \mathrm{E}+01$ \\
\hline (Ethylene) Glycol Dimethyl Ether & 0.800 & 3213 & $110-71-4$ & Ilquild & -6 & 0.867 & -58 & 61.2 & $\|$ & & & & \\
\hline Elhyl Ether & 47.296 & 3762 & $60-29-7$ & llquid & -45 & 0.700 & -123 & 442 & I1. $\theta x$ & $2.00 E-01$ & & $1.60 E+04$ & \\
\hline Hexanitrodiphenylamine & 0.345 & 3340 & $131-73-7$ & solld & 29 & 1.640 & 243 & dec & ox & & & & \\
\hline Hydrazine Monohydrale & 3.300 & 4692 & $7803-57-8$ & liquid & 76 & 1.032 & -50 & & $H_{1}, r v, t x$ & & & & \\
\hline Hydroxylamine Hydrochloride & 0.250 & 4759 & $5470-11-1$ & solld & 140 & 1.670 & 151 & dec & ex, ms & & & & \\
\hline |sopropyl Alcoholttt; sym. Propanol & $<2$ & 5096 & $67-63-0$ & liquld & 11.7 & 0.786 & -89 & 40 & II & & & & \\
\hline
\end{tabular}


Table 4-3. Physical Properties and MTCA Method B Cleanup Levels for Discarded Chemical Products at the Hanford Patrol Academy Demolition Sites. (sheet 2 of 3 )

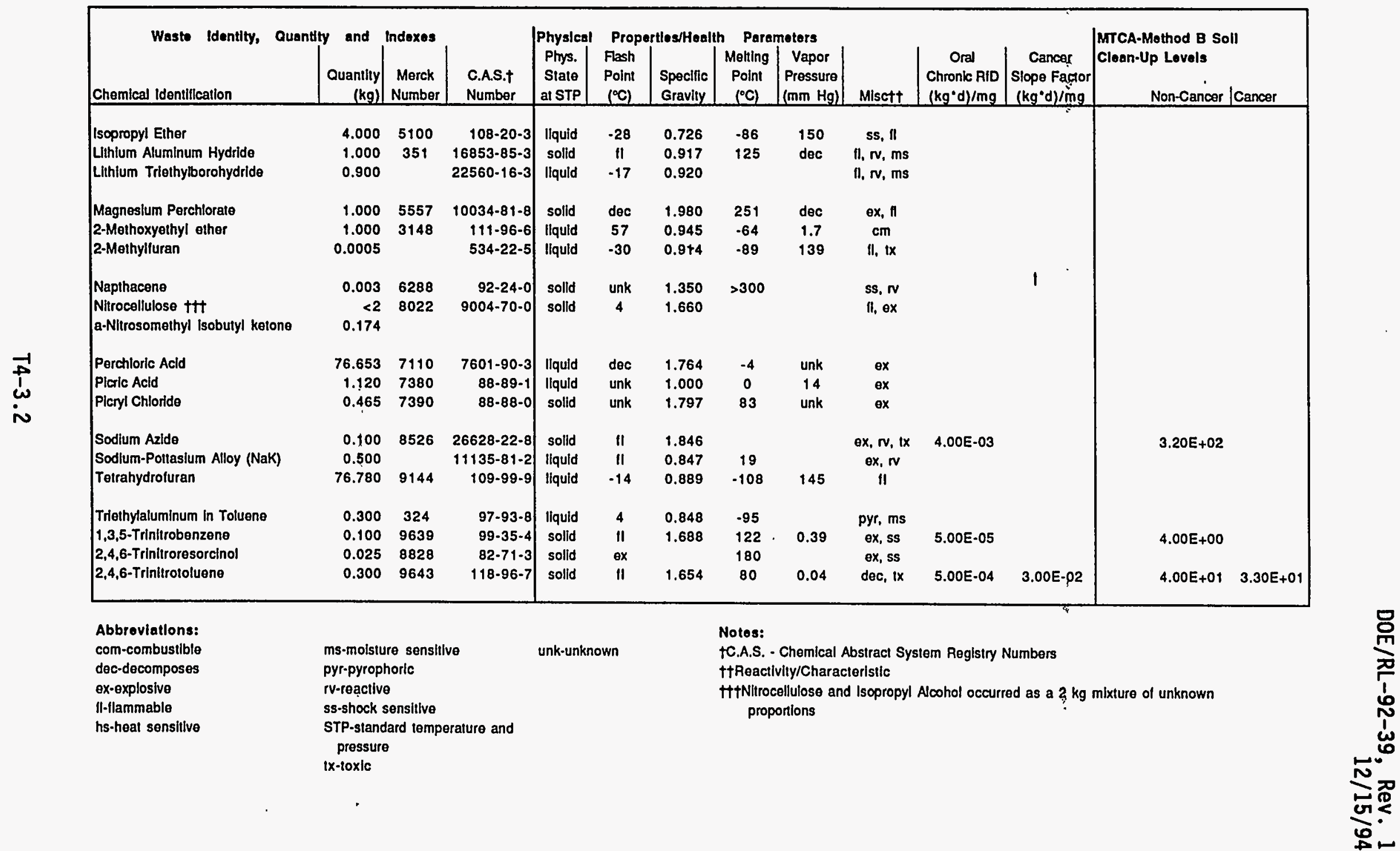


1 Table 4-3. Physical Properties and MTCA Method B Cleanup Levels for Discarded Chemical Products

\section{Equations:}

Non-Cancer Cleanup Level $=($ RID $\cdot A B W \cdot$ UCF $\cdot H Q) /(S I R \cdot A B I \cdot F O C)$

Cancer Cleanup Level = (RISK • ABW • LIFE • UCF)/(SIR • ABI • DUR • FOC)/Cancer Slope Factor

Paramotors:

\begin{tabular}{llll} 
& Units & \\
\hline & & non-cancer & cancer \\
Unit Conversion Factor (UCF) & $\mathrm{mg} / \mathrm{kg}$ & $1 E+06$ & $1 E+06$ \\
Average Body Weight (ABW) & $\mathrm{kg}$ & 16 & 16. \\
Soll Ingestion Rate (SIR) & $\mathrm{mg} / \mathrm{day}$ & 200 & 200 \\
Gastointestinal Absorption Rate (ABI) & & 1 & 1 \\
Frequency of Contact (FOC) & & 1 & 1 \\
Hazard Quotient (HG) & & 1 & 75 \\
Lifetime (LIFE) & yrs & & 6 \\
Duration of Exposure (DUR) & yrs & & $1 \mathrm{~T}-06$ \\
Cancer Risk Level (RISK) & & &
\end{tabular}


Table 4-3. Hanford Patrol Acadamy Demolition Site Dicsarded Chemical Products Physical Properties and MTCA Method B Clean-Up Levels

Equatlons:

Non-Cancer Cloanup Level = (RID * ABW * UCF * HO) $/(S I R \cdot A B I * F O C)$

Cancer Cleanup Level = (RISK • ABW * LIFE * UCF $/(S I R * A B I \bullet D U R ・ F O C) /$ Cancer Slope Factor

\section{Paramotors:}

\begin{tabular}{|c|c|c|c|c|}
\hline & Units & & & \\
\hline & & non-cancer & cancer & $:$ \\
\hline Unit Conversion Factor (UCF) & $\mathrm{mg} / \mathrm{kg}$ & $1 E+06$ & $1 E+06$ & \\
\hline Average Body Weight (ABW) & kg & 16 & 16 & \\
\hline Soll Ingestlon Rate (SIR) & $\mathrm{mg} /$ day & 200 & 200 & \\
\hline Gastointestinal Absorption Rate (ABI) & & 1 & 1 & \\
\hline Frequency of Contact (FOC) & & 1 & 1 & \\
\hline Hazard Quotlent (HG) & & 1 & & \\
\hline Lifetime (LIFE) & & & 75 & \\
\hline Duration of Exposure (DUR) & yrs & & 6 & \\
\hline Cancer Risk Level (RISK) & yrs & & 1E-06 & \\
\hline
\end{tabular}




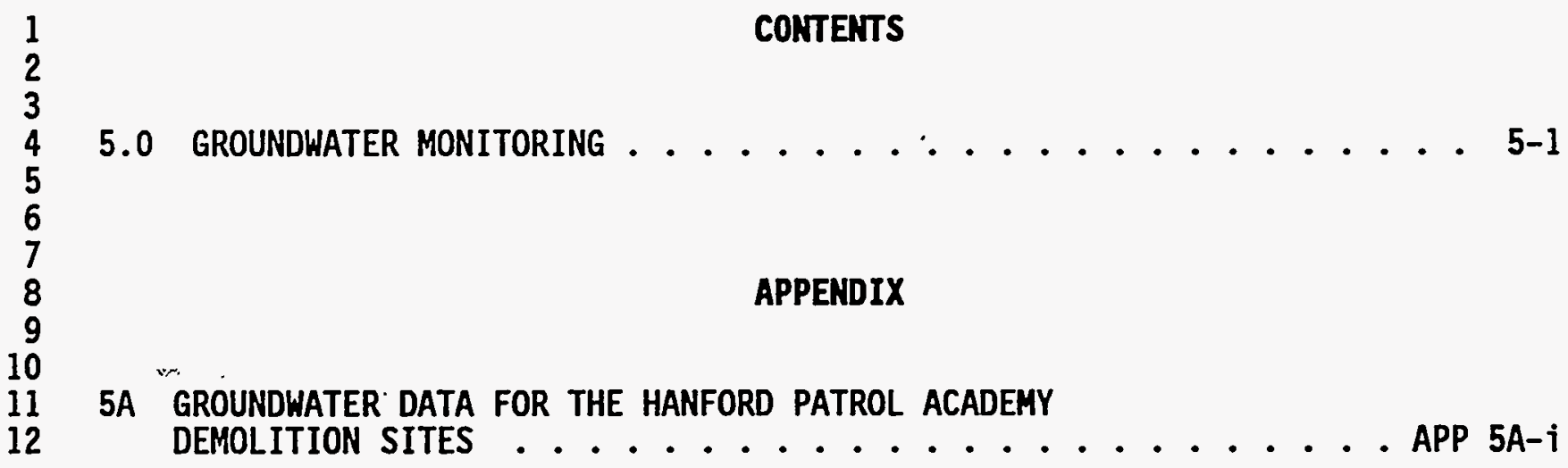


DOE/RL-92-39, Rev. 1

$12 / 15 / 94$

This page intentionally left blank. 


\subsection{GROUNDWATER HONITORING}

Based on knowledge of the demolitions conducted at the HPADS, and on 7 imited but pertinent groundwater information, it is considered extremely unlikely that the demolition site chemicals interacted with groundwater because (1) rainfall at the Hanford Site is slight, thus limiting contaminant migration, and (2) it is believed that all significant quantities of chemicals were destroyed in the explosion or volatilized to the atmosphere.

A characterization of groundwater quality and geohydrologic conditions in the vicinity of HPADS is presented in Appendix 5A. Groundwater wells that monitor the uppermost unconfined aquifer exist at two locations near the HPADS. At one of the locations, a well also monitors the uppermost confined aquifer. These wells were constructed before RCRA standards, and are not optimally located to monitor flow underneath the HPADS. Groundwater at the wells currently is monitored as part of the Hanford sitewide environmental surveillance program conducted by Pacific Northwest Laboratory under U.S. Department of Energy Order 5400.1. 
DOE/RL-92-39, Rev. 1

$12 / 15 / 94$

This page intentionally left blank. 
6.0 CLOSURE STRATEGY AND PERFORMANCE STANDARDS . . . . . . . . 6-1

6.1 ClOSURE STRATEGY . . . . . . . . . . . 6-1

6.2 CLOSURE PERFORMANCE STANDARDS . . . . . . . . . . 6-2 6.2.1 Minimize the Need for Future Maintenance . . . . . 6-2

.... 6...2.2, Pratect Human Heal th and the Environment. . . . . . 6-2 6.2.3 Return Land to the Appearance and Use of Surrounding Lañd............ 6-. 6-.

6.3 OVERVIEW OF CLOSURE ACTIVITIES ............ . 6-3 6.3 .1 Planning Activities ............ 6-... 6-. 6.3 .2 Physical Activities ............. 6-3

23 6-1. Closure Strategy Flowchart ............... F6-1 


\section{DOE/RL-92-39, Rev. 1 $12 / 15 / 94$}

This page intentionally left blank. 


\subsection{CLOSURE STRATEGY AND PERFORMANCE STANDARDS}

This chapter describes the closure strategy, closure performance standards, and overview of closure activities.

\subsection{CLOSURE STRATEGY}

C7ean closure is the proposed closure strategy (Figure 6-1). Data from chemical analyses of soil samples will be used to confirm closure. All other materials (e.g., buildings) were purposely kept beyond the potential influence of the demolition events. Therefore, only the soil media will be tested to determine closure.

Soil samples have been taken in and adjacent to the boundaries of the HPADS as specified in the Sampling and Analysis Plan (SAP) (Appendix 7C). In order to clean close the HPADS, soil analytical results must verify that potentially dangerous waste constituents treated at the site are not present above action levels. The analytical results will be evaluated and compared with action levels to verify that the concentration of all detonation activity residues are at or below action levels. The closure area boundary locations, constituents of concern, and the analytical methods were agreed on through the DQO process by taking into account the waste inventory, reactive by-products, chemical degradation, and detonation materials. The analytical methods are Tisted in the SAP (Appendix 7C).

Action levels are defined as levels above the Hanford Site soit background levels identified in the Hanford Site Background: Part 1, Soil Background for Nonradioactive Analytes (DOE-RL 1993) and the Model Toxics Control Act (MTCA) (WAC 173-340) Method B. If data indicate that levels are above both these guidelines, a Phase II investigation will be developed. This is not anticipated because of the efficiency of the detonation reaction and weathering of unreacted residues.

For noncarcinogens, the principal variable relating human health to action levels is the oral reference dose. It is defined as the level of daily human exposure at or below which no adverse effect is expected to occur during a lifetime. For carcinogens, the cancer slope factor is the basis for determining human health effects; it is a measurement of risk per unit dose: The oral reference dose and cancer slope factor are chemical specific and are obtained from the integrated risk information system (IRIS) database (EPA 1989). Health-based levels will be based on values that are current at the time of approval of this plan.

The HPADS is not located within the boundaries of a Comprehensive Environmental Response, Compensation, and Liability Act of 1980 (CERCLA) operable unit. If, in the course of closure, contaminants not associated with the operation of the TSD unit are detected, a solid waste management unit (SWMU) will be created and the site will be remediated as a RCRA past practice (RPP) activity. 


\subsection{CLOSURE PERFORMANCE STANDARDS}

The closure performance standards in WAC 173-303-610(2) require the owner or operator to close the TSD unit in a manner that:

"(a)(i) Minimizes the need for further maintenance;

(ii) Controls, minimizes or eliminates to the extent necessary to protect human health and the environment, postclosure escape of dangerous waste, dangerous constituents, leachate, contaminated. run-off, or dangerous waste decomposition products to the ground, surface water, ground water, or the atmosphere; and

(iii) Returns the land to the appearance and use of surrounding land areas to the degree possible given the nature of the previous dangerous waste activity."

\subsubsection{Minimize the Need for Future Maintenance}

The closure performance standard in WAC 173-303-610(2)(a)(i) requires the owner or operator of a TSD unit to close the site in a manner that minimizes the need for further maintenance. As discussed in Section 6.1, the strategy proposed for closure (i.e., that the site is clean by demonstration that the contaminants are below action levels or by waste removal) will minimize the need for future maintenance.

\subsubsection{Protect Human Health and the Environment}

The HPADS is to be clean closed. Consistent with this intent and strategy, the following actions will be/or have been taken (as necessary) in advance of closure certification.

- Surface soils will be sampled and analyzed for dangerous waste constituents.

- If necessary, contaminated soil will be removed to attain acceptable soil cleanup values as determined by methods prescribed in WAC 173-340. Verification sampling and analysis witl be performed.

\subsubsection{Return Land to the Appearance and Use of Surrounding Land}

In accordance with WAC $173-303-610(2)(a)(i i j)$, the owner or operator of a TSD unit is required to close the unit in a manner that returns the 1 and to the appearance and use of surrounding 1 and areas to the degree possible given the nature of the previous dangerous waste activity.

When clean closed, the HPADS closure areas will be returned to the Hanford Patrol Academy. The Hanford Patrol Academy training activities are expected to continue to about the year 2050 . 
The proposed mode of closure for the HPADS is clean closure. No specific closure activities are proposed for the demolition sites that would involve reconfiguration of the surface of the sites. However, minor regrading or revegetation may be performed for fire prevention or safety reasons (e.g., bullet ricochets). In the present condition, the demolition sites conform to the use and appearance of surrounding land.

\subsection{OVERVIEN OF CLOSURE ACTIVITIES}

The activities presented in this section are divided into planning and physical activities.

\subsubsection{Planning Activities}

The DQO planning process was used to ensure that the performance standards are met to the satisfaction of all the stakeholders. This DQO process provided the framework for the SAP and defined the data needs and uses. The SAP provides the documentation of agreement and decisions regarding establishing and meeting action levels for the HPADS.

\subsubsection{Physical Activities}

The physical activities that lead to closure are as follows. The details of the closure activities are provided in Chapter 7.0.

- Collect soil samples from within the closure areas and from surrounding soils. Sample locations and collection methods are discussed in Chapter 7.0, Section 7.2.3, Sampling Methodology.

- Analyze samples in accordance with EPA-approved procedures and evaluate analytical results. Samples will be analyzed in an offsite contract 7aboratory capable of performing to EPA Analytical level III standards.

- Compare analytical results to action levels to determine the presence or absence of contaminants, to determine the extent of contamination, or to facilitate decisions concerning remediation.

- If contamination levels for all constituents of concern listed in Chapter 7.0, Table 7-1, are below the action levels, the HPADS will be clean closed. 
- If contamination at the HPADS is above the action levels in the near-surface soils, one of the following actions will be taken.

- If the contamination is from HPADS activities only, soil will be treated and/or disposed of in a RCRA-permitted landfill.

- If the soil is contaminated with dangerous waste constituents from other sources in addition to HPADS activities, the site will be evaluated as a new SWMU. The site would then be turned over for RPP remediation.

- If the soil is contaminated only from sources other than HPADS activities, the site will be evaluated as a new SWMU and remediation will occur under RPP remedial action of the SWMU.

Al1 equipment used in performing closure activities will be decontaminated or disposed of at a RCRA-permitted facility.

Closure activities will be monitored by an independent registered professional engineer who will certify that closure activities are accomplished in accordance with the specifications of the approved closure plan. The certification will be sent by registered mail or an equivalent delivery service. 


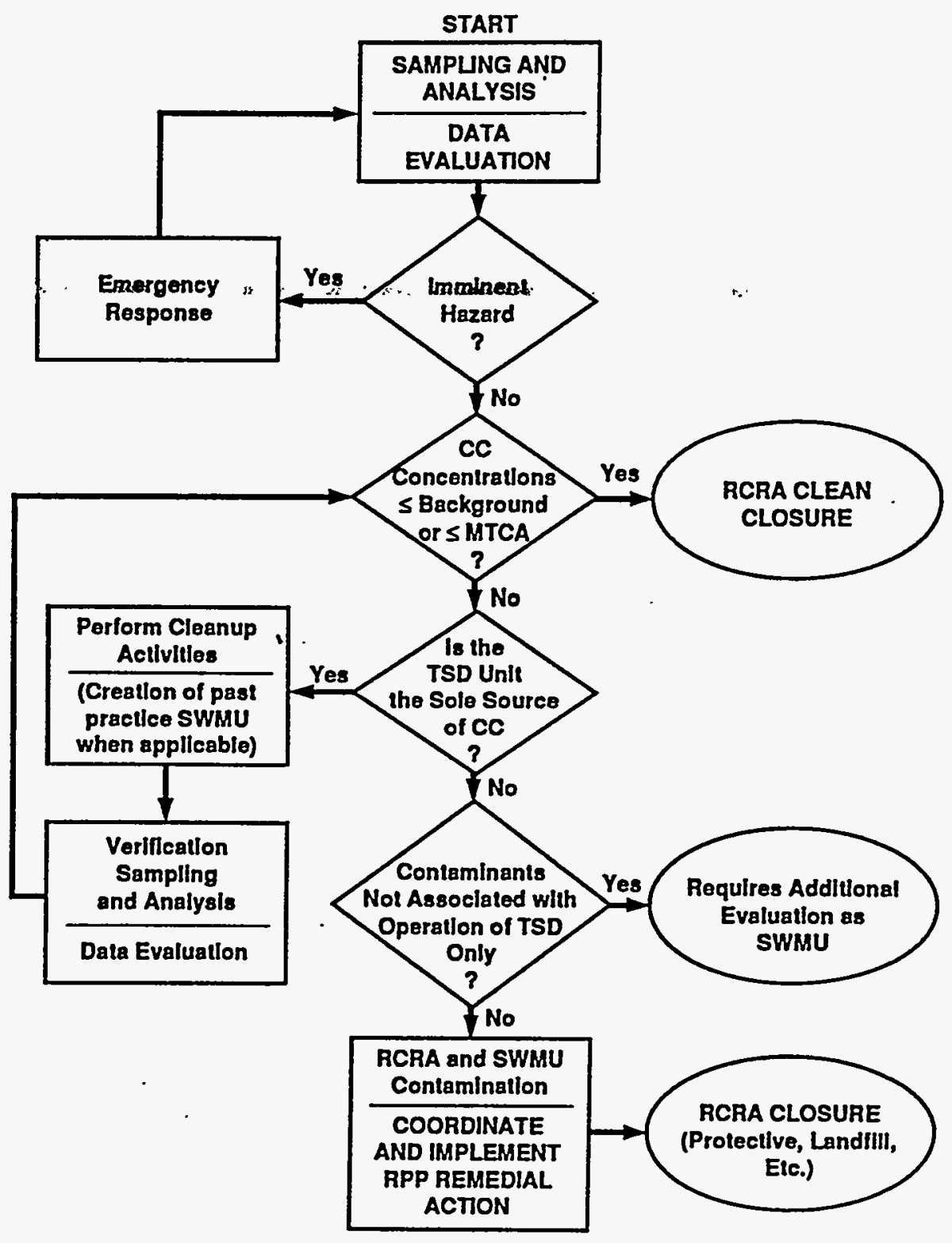

H9410016.1

\footnotetext{
CC $=$ Contaminants of concern.

Background = Hanford Site-wide background threshold (upper limit of the range of concentrations) for soil (DOE-RL 1993).

Clean Closure $=$ Closure based on the criterion that dangerous waste is not present in concentrations greater than background or MTCA Method B; no further renedial action to be taken. RPP $=$ RCRA past practice.

DH $=$ Dangerous waste as defined in UAC 173-303.

sum = Solid Waste Management Unit

Verification Sampling = Sampling and analysis used to evaluate the success of conteminant removal .
}

Figure 6-1. Closure Strategy Flowchart.

\section{F6-1}




\section{CONTENTS}

7.0 ClOSURE ACTIVITIES ...................... 7-1

7.1 GROUND-PENETRATING RADAR SURVEY ............ 7 . . .

7.2 SOIL SAMPLING AND ANALYSIS CRITERIA ........... . 7-1

7.2.1 Sampling and Data Quality Objectives ........ 7-2

7.2.2 Analxtical Parameters ............. 7-4

7.2.3 Soil Sampling Methodology ............ 7-4 7.2.3.1 SampTe Locations ............ . 7-4 7.2.3.2 Background Samples .......... 7-5

7.2 .4 Field Documentation ............ 7-5

7.2 .5 Evaluation of Data . . . . . . . . . . 7-5

7.2:6 Statistical Evaluation . . . . . . . . 7-6

7.2.7 Determination of Proposed Action Levels . . . . . 7-6

7.3 REMOVAL OF CONTAMINATED SOIL ........... . . . .

7.3.1 Estimating the Volume of Contaminated Soil

to be Removed .............. 7-7

7.3.2 Soil Removal Survey Controt . . . . . . . 7-7

7.3.3 Soil Removal Operations . . . . . . . . 7-8

7.3.4 Verification Sampling ............ 7-8

7.4 PERSONNEL TRAINING . . . . . . . . . . . 7-9

7.5 SCHEDULE FOR CLOSURE ................ . . . . . .

7.6 CLOSURE CONTACTS . . . . . . . . . . . . 7-9

7.7 AMENDMENT OF CLOSURE PLAN . . . . . . . . . . . 7-9

7.8 CERTIFICATION OF CLOSURE AND SURVEY PLAT . . . . . . . 7-10

\section{APPENDICES}

7A QUALITY ASSURANCE PROJECT PLAN" FOR. SOIL SAMPLING AND

ANALYSIS FOR THE HANFORD PATROL ACADEMY DEMOLITION SITES . . APP 7A-i

7B TRAINING COURSE DESCRIPTIONS ..................... 7B-

$7 C$ SAMPLING AND ANALYSIS PLAN ...................... 7 .

\section{FIGURES}

7-1. Hanford Patrol Academy Demolition Sites Closure Schedule . . . . F7-1

7-2. Typical Closure Certification Document ......... F7-2 
DOE/RL-92-39, Rev. 1

$12 / 15 / 94$

This page intentionally left blank. 


\subsection{CLOSURE ACTIVITIES}

This chapter describes the proposed closure activities for the HPADS. In conformance with Chapter 6.0, this chapter provides the specific field sampling and laboratory analytical procedures that will be applied to identify the soil contamination (if any) that originated from TSD unit activities at the HPADS. When validated, the analytical results will be used to determine the appropriate closure strategy (presented in Chapter 6.0 and illustrated in Figure 6-1). The SAP (Appendix 7C) has been developed from the process information (Chapter 3.0), waste inventory (Chapter 4.0 ), and the closure strategy (Chapter 6.0). Appendix 7A is the quality assurance project plan (QAPJP) for soil sampling and analysis.

\subsection{GROUND-PENETRATING RADAR SURVEY}

As discussed in Chapter 2.0, in 1975 a canister of napalm B might have been buried in one of the HPADS closure areas. Although this napalm canister was not associated with the RCRA activities at the HPADS, there was a concern that the canister might be encountered during sampling of the closure areas and could be a threat to the sampling personnel. Therefore, to ensure worker safety, a ground-penetrating radar (GPR) survey was planned to check the closure areas to determine if the canister was present in the shallow subsurface of either area. On September 26, 1994, a preliminary GPR survey was performed. Because of the presence of copious foreign debris (e.g., bullets, spent cartridges) and rocks, anomalous radar signatures were generated. Ground-penetrating radar personnel determined that the presence or absence of the canister could not be ascertained. Because sampling of the HPADS was completed on September 26, 1994 without incident, no further action will be taken to locate the napalm canister.

Performance of GPR surveys is described in Environmental Investigation Instructions (EII) 11.2, "Geophysical Survey Hork, Appendix A: GroundPenetrating Radar" (WHC 1988a). This EII provides descriptions of the equipment used, calibration, maintenance, and data collection procedures, and data interpretation.

\subsection{SOIL SAMPLING AND ANALYSIS CRITERIA}

The DQO planning process was used to develop a two-phase soil sampling and analysis approach. Phase I soil samples were collected to assess whether dangerous waste constituents are present in surface soils at the two HPADS closure areas. These samples were analyzed at an offsite analytical level III Taboratory. If contaminants are present at Tevels in excess of proposed action levels, the stakeholders will reconvene and a Phase II sampling program will be planned. 


\subsubsection{Sampling and Data Quality Objectives}

To create a suitable soil sampling and analysis scheme, it was necessary to have a general understanding of explosives and detonations. An explosive is a chemical or a mixture of chemicals capable of producing an explosion (i.e., detonation) through the liberation of stored energy. A11 explosive substances produce heat; nearly all of them produce gas (Davis 1943). Explosives are classified as low explosives (or propellants), primary explosives (or initiators), and high explosives. Low explosives are combustible materials, which always include an oxidizer component, such that combustion is supportable whether or not air is present. Low explosives burn but do not explode. Instead, rapid accumulation of the gas products of combustion in a confined space is the cause of the explosion.

Primary and high explosives undergo an instantaneous chemical transformation when detonation is initiated, which liberates large quantities of heat or heat and gas, thus producing an explosion. Detonation is distinct from combustion. By themselves, many primary and high explosives will not support combustion. Primary explosives are sensitive to both heat and shock. High explosives generally exhibit sensitivity to shock only, and generally must receive a relatively strong shock, as from a primary explosive, to detonate. Primary and high explosives are characterized by a property termed brisance, referring to the production of a shock wave during detonation, because of the characteristically high propagation velocities involved.

Chemicals that were identified as candidates for demolition at the HPADS included strong oxidizers and reducing agents (i.e., low explosives when combined), chemicals such as ethers and furans that are highly flammable and form shock-sensitive degradation products, and chemical compounds that were recognized as primary or high explosives or chemical cognates of such explosives.

The HPADS demolition events could be characterized as follows.

- Initiation by a primary explosive, resulting in propagation of a shock wave through the mass of chemical containers. The shock wave would have caused any other primary or high explosive chemicals present to detonate.

- Nonexplosive chemicals would be dispersed (in the case of solids), or atomized (in the case of liquids), directed upward (the only unconfined direction) by the partial confinement of the shallow pit, and ignited by the heat released by the explosion, causing the firebal1. The explosion also could have had the effect of fragmenting some of the chemicals that were present.

- The shock wave from the explosion and the expanding gases from the fireball would have caused unreacted residues (if any) to be dispersed within 3 radii [15 feet ( 4.6 meters)] of the origina] blasting surface. 
Before October 1984, HPADS demolition of individual containers was initiated by rifle fire. For most demolition events after 1984, the assembled collection of chemical containers was wrapped with detonating cord (a primary explosive), surrounded by a blasting agent (propellant) and/or a high explosive (dynamite), and initiated electrically. In each multiple-chemical demolition event, detonation was typically accompanied by a distinct fireball (indicative of combustion).

Some chemical residues can persist in the surface soil for many years. However, "in the intervening time since the most recent demolition event on October 27, 1991, volatile organic residues in the soil might have been lost to the atmosphere through vaporization. Unreacted volatiles and semivolatiles also might have been reduced in the soil column by microbial activity and exposure to the desert environment (e.g., volatilization and photodegradation).

The primary objective of soil sampling is to determine whether dangerous waste contaminants are present in surface soils at the HPADS at levels exceeding the proposed action levels. Potential contaminants (i.e., constituents of concern) were selected based on the waste inventory for the HPADS. Analytical methods were required to provide the capabilities to identify and quantify these constituents if the constituents are present in the soit.

If dangerous waste constituents are present at or above proposed action levels, a second objective of sampling is to determine the extent and areal distribution of contamination. The efficiency of thermal destruction during the demolition events is not directly assessable at this late date. Any chemical constituents that were not effectively destroyed in the explosion simply might have been dispersed across the detonation site. Recognizing this possibility, the sampling scheme was designed to obtain data that will, if necessary, support an assessment regarding the adequacy of existing HPADS closure area dimensions.

It is generally acknowledged that detonation and thermal destruction are efficient processes, and that any dangerous waste constituents that might remain in the soil at either closure area probably would exist at very low concentrations, such that detection might be difficult. Therefore, a sufficiently conservative EPA analytical support level (level III) was invoked for analysis to minimize concerns that dangerous waste concentrations above the proposed action levels would be undetected.

Data quality objectives were developed to describe the overall level of uncertainty in environmental data that decisionmakers are willing to accept. Typically, data quality requirements are specified in terms of objectives for precision, accuracy, representativeness, comparability, and completeness. Project-specific DQOS for HPADS soil sampling activities are identified in Appendix 7A and the SAP (Appendix 7C). 


\subsubsection{Analytical Parameters}

As 1 isted in Chapter 4.0, Tables 4-1 through 4-3, the demolition events at the HPADS closure areas included a variety of organic and inorganic constituents that were (or were suspected to be) characteristic reactive and/or ignitable waste (as defined in WAC 173-303-090). The majority of the chemical compounds were of two general types: (1) organic chemicals that form unstable degradation products (e.g., ethers and furans that produce shock-sensitive peroxides) and (2) reactive powdered metals and metal salts. The analytical methods of interest for Phase I sail sampling are listed in. Section 6.0 of the SAP (Appendix 7C).

\subsubsection{Soil Sampling Methodology}

The following sections discuss sample locations, background samples, and analytical instrumentation and procedures.

7.2.3.1 Sample Locations. Soil samples were taken from the locations indicated in the SAP (Appendix 7C). The numbers and types of samples collected and submitted for analysis per EII procedures consisted of the following.

Closure Area No. 1:

- Eleven soil samples were collected for full analysis from region $A$ and $B$ in Closure Area \#1 as shown in Figure 2 of the SAP (Appendix 7C). Four samples were collected in Region $A$, where the detonations occurred. Seven samples were collected in region $B$, where any unreacted residues would have been distributed as a result of grading (Chapter 3.0).

- Two field split samples were collected from region A for full analysis.

Closure Area No. 2:

- Fourteen soil samples were collected for full analysis from specific locations within a 15-foot (4.6-meter) radius centered about the detonation pit as shiown in Figure 3 of the SAP (Appendix 7C).

- Two field split samples were collected from the center of the detonation pit for full analysis.

The Phase I sampling activities at Closure Areas \#1 and \#2 occurred on the same day (September 26, 1994); therefore, one equipment blank (silica sand) for fult analysis and one trip blank (silica sand) for volatile organic analysis only were collected.

Samples were collected using decontaminated hand tools at each closure area. At each location sampled, windblown soil and debris were pushed aside. Samples were taken from two distinct intervals 0 to 6 inches ( 0 to 
15 centimeters) and 12 to 18 inches ( 30 to 46 centimeters) below grade, as specified in the SAP (Appendix 7C). Chemical residues from the demolition events would have been deposited on the surface of the soil column. Over time, the soluble constituents would have undergone gradual removal by successive wetting fronts (from rainfall and snowmelt events) and redeposited lower in the soil profile. With the proposed sampling approach, leachable or otherwise mobile constituents that might have been reduced to concentrations below detection limits at the soil surface still could be detected at depth. If volatile organics remain in the soil at the closure areas, they will be more readily detectable at shallow depths below the soill surface, rather, than. in the 0 to 6-inch (.0 to 15-centimeter) interval. Specific soil sample locations and depths are described in the SAP (Appendix 7C). The soil samples were analyzed at an offsite, level III laboratory.

Soil samples (including blanks and field splits) received preassigned sample numbers in conformance with EII 5.10, "Obtaining Sample Identification Numbers and Accessing HEIS Data" (WHC 1988a). The samples were chilled on ice per EII procedures. Samples were stored temporarily and transported to the analytical laboratory in an ice chest.

\subsubsection{Background Samples. A Hanford Sitewide assessment of natura1 constituent background levels has been performed (WHC 1991a; WHC 1991b). The majority of dangerous waste constituents detonated at the HPADS closure areas were organic chemicals, for which background values are unavailable. For these constituents, concentration data will be compared to MTCA Method B levels. A few compounds on the waste inventory contained inorganic metal and halide elements. Residues from these compounds could include oxides, cations, and/or various anions with nonzero background values. Results from the Hanford Sitewide assessment will be available for use in data interpretation. The adequacy of available Hanford Sitewide background data for HPADS site- specific contaminants will be evaluated in conjunction with the interpretation of soil sample analytical results. No independent assessment of local background values is planned to support closure.}

\subsubsection{Field Documentation}

The field team leader maintained a logbook during soil sampling and GPR surveying activities, in accordance with EII 1.5, "Field Logbooks" (WHC 1988a). Information pertinent to ongoing activities at the closure areas. was recorded in a legible manner with indelible ink in the logbook.

\subsubsection{Evaluation of Data}

Data reliability will be evaluated through a review of field documentation, sample handling procedures, analytical procedures, offsite laboratory documentation, and calibration records. The purpose of the review will be to establish the reliability of the data by verifying that the samples were labeled, handled, and controlled in a manner designed to minimize the possibility of physical misidentification. Procedures for quality control documentation will follow SH-846, Chapter 1, "Quality Assurance" (EPA 1990). 
Analytical data returned from the contract laboratory will be validated according to requirements described in Data Validation Procedures for Chemical Analyses (WHC 1993).

\subsubsection{Statistical Evaluation}

Analytical results will be reviewed and summarized. Procedures for calculating detection and quantitation limits of constituents and for repokting af data wi 71 follow the guidance, in SW-846, Chapter, 1, "Quality Assurance" (EPA 1990) and Characterization and Use of Soil and Groundwater Background for the Hanford Site (WHC 1991a). Constituents will be eliminated from further consideration in cases where all results are below detection limits (provided the detection limit is below background). For the remaining constituents, data will be tabulated for statistical evaluation. Summary statistics will be computed. The following information for individual constituents will be summarized for presentation:

- Total number of values

- Number of values less than detection limits

- Minimum value

- Maximum value

- Median

- Mean

- Standard deviation

- Coefficient of variation.

Data analysis and evaluation procedures will be used that: (1) balance the false positive and false negative error rates; (2) are appropriate for the distribution of sample data for each analyte; and (3) are consistent with the nature of the data (e.g., the proportion of 'nondetects' in the data sets) and the applicable regulatory limits (background values or risk-based standards). Appropriate statistical methods might include (but would not be limited to) tests on means, percentiles, and/or proportions.

\subsubsection{Determination of Proposed Action Levels}

Soil cleanup action levels were developed from Hanford Site background threshold values (BOE-RL 1993) and MTCA Method B (WAC 173-340). Action levels were developed for a 11 contaminants of concern during the DQO process (Appendix $7 C$ ). Contaminant levels will be compared to proposed action levels to assess the need for remedial action. If a determination is made that some remedial action is necessary as a condition of closure, a remedial action plan will be prepared. 


\subsection{REMOVAL OF CONTAMINATED SOIL}

If soil sampling results and assessments of remedial options indicate that soil removal is necessary to close the HPADS, this section of the closure plan will be implemented as indicated in Figure 6-1. This section describes the following activities relating to soil removal:

- Estimating the volume of contaminated soil to be removed

- Soil removal survey control

- Soin removal operations.

- Verification sampling.

\subsubsection{Estimating the Volume of Contaminated Soil to be Removed}

The volume of contaminated soil will be determined based on soil sampling results (i.e., the indicated constituents and their respective concentrations and distributions) and the constituent-specific proposed action levels (i.e., soil cleanup values). The volume of contaminated soil will be calculated in the following manner.

- Soil sample information will be plotted on a closure area plan drawing.

- For each contaminated area, the volume of soil to be removed will be estimated by the results obtained in the initial characterization.

- A Phase II investigation will be proposed to define the location of soil constituents of concern. The location of the site contamination must be known with some degree of certainty to begin any soil excavation. Supplemental sampling with portable field screening instrumentation might be carried out to better define the areal extent of contamination.

\subsubsection{Soil Removal Survey Control}

Corner stakes have been installed at each closure area boundary to provide survey control for soil sampling. Corner monuments may be installed to serve as control points (i.e., semipermanent reference points with known horizontal and vertical coordinates) for any soil removal excavation work. If removal of contaminated soil at either closure area is necessary for closure, additional survey control may be provided as needed to effectively manage and document the excavation work. As preliminary actions, a survey grid will be projected over the area to be excavated, and a controlled drawing of the existing site topography will be prepared identifying all control point positions and soil sample locations. Depending upon the size and shape of the excavation area, elevation surveys and grade stakes will be used (as appropriate) to control the work. The controlled drawing will be modified to show the extent of soil removed and the final site surface configuration. Afterward, the survey grid and the drawing(s) will assist in location control and documentation for verification sampling. 


\subsubsection{Soil Removal Operations}

If soil removal is necessary and if the contaminated soil volume is sufficient, the soil removal operation will be performed using standard types of earth-moving equipment (e.g., grader, front-end loader, backhoe, and rear dump trucks). Excavation will be performed with either a backhoe or a front-end loader. Dust suppression would be employed, if needed, to minimize dust generation and potential releases of contaminants (e.g., a water truck could apply water periodically to the excavation area and adjacent affected areas). Dust-control activities will be repeated as necessary to maintain the soil in a condition sufficient to minimize or eliminate dust production.

If the contaminated soil volume is small, 55-gallon (208-1iter) containers will be used. Alternatively, soil could be bulk loaded into rear dump trucks. Contaminated soil (containerized or bulk loaded) will be transported to a permitted (or interim status) disposal facility. Contaminated soil will be prepared for shipment (i.e., labeled, marked, and placarded) as required in WAC 173-303-190, which incorporates by reference the applicable federal regulations on hazardous waste shipments (49 CFR 172, 173, 178, and 179). An EPA hazardous waste manifest will be prepared to document each offsite shipment of contaminated soil as required in WAC 173-303-180 and 40 CFR 262.

If soil removal is necessary, the affected area will be recontoured with surrounding soils. After excavation and before recontouring of the removal areas, the affected area will undergo verification sampling (Chapter 6.0 , Figure 6-1). Recontoured surface elevations will be checked against firing range design elevations to ensure that the firing range can fulfill its intended purpose. A final revision of the controlied closure area map will be prepared to show the 'as built' configuration of the firing range.

As appropriate, the destination of any removed soi] will be identified in the Administrative Record for HPADs. This identification will be undertaken concurrently with the closure certification (Section 7.8 ).

\subsubsection{Verification Sampling}

Verification sampling will be performed following soil removal to estabTish that residual concentrations of the constituents of concern are below action levels ( $i . e$. , the objective of soil removal has been attained). Verification samples will be taken from the newly exposed surface resulting from soil removal. Verification samples will be analyzed in an offsite contracted laboratory. The scope of sample analysis will be 1 imited to quantifying the residual concentrations of constituents of concern to compare these concentration values to the cleanup standards. Before verification sampling, the number and location of the samples and the analytical methods will be submitted for regulatory concurrence. It is envisioned that verification samples would be analyzed by the same procedures identified in Section 7.2.2. 


\subsection{PERSONNEL TRAIHING}

Appendix $7 B$ contains a brief description of the training courses. Training for soil sampling personnel is covered within the EIIs. All personnel entering the TSD unit during closure must have 40 hours of hazardous waste training as defined in 29 CFR 1910.120. Before performing closure activities, specific work plans will be submitted to the lead regulatory agency for review. These documents will detail the specific work activities and will not be written until the latest technology and specific materials and equipment are.known:

\subsection{SCHEDULE FOR CLOSURE}

Closure of the HPADS will begin on notification by Ecology of plan approval: Closure will proceed according to the schedule presented in Figure 7-1.

\subsection{CLOSURE CONTACTS}

The following office (or its successor) is the official contact for the Hanford Patrol Academy Demolition Sites closure plan:

Office of Environmental Assurance, Permits, and Policy

U.S. Department of Energy, Richland Operations Office 825 Jadwin Avenue P.0. Box 550

Richl and, Washington 99352

(509) 376-5441

\subsection{AMENDHENT OF CLOSURE PLAN}

The closure plan for the HPADS will be amended whenever changes in operating plans or unit design affect the closure plan; whenever there is a change in the expected year of closure; or if, when conducting closure activities, unexpected events require a modification of the closure plan. The closure plan will be modified in accordance with WAC 173-303-610. This plan may be amended any time before certification of final closure of the HPADS.

If an amendment to the approved closure plan is required, the DOE-RL will submit a written request to the lead regulatory agency to authorize a change to the approved plan. The written request will include a copy of the closure plan amendment for approval. 
1

2

\subsection{CERTIFICATION OF CLOSURE AND SURVEY PLAT}

Within 60 days of closure of the HPADS, the DOE-RL wi1l submit to the Benton County Auditor and the lead regulatory agency a certification of closure and a duly certified survey plat. The certification of closure will be signed by both the DOE-RL and a registered independent professional engineer, stating that the unit has been closed in accordance with the approved closure plan. The certification will be submitted by registered mail or an equivalent delivery service. Documentation supporting the independent registered professional engineer's certification will be supplied on request. of the regulatory authority.

The DOE-RL and the independent professional engineer will certify with a document similar to Figure 7-2. 


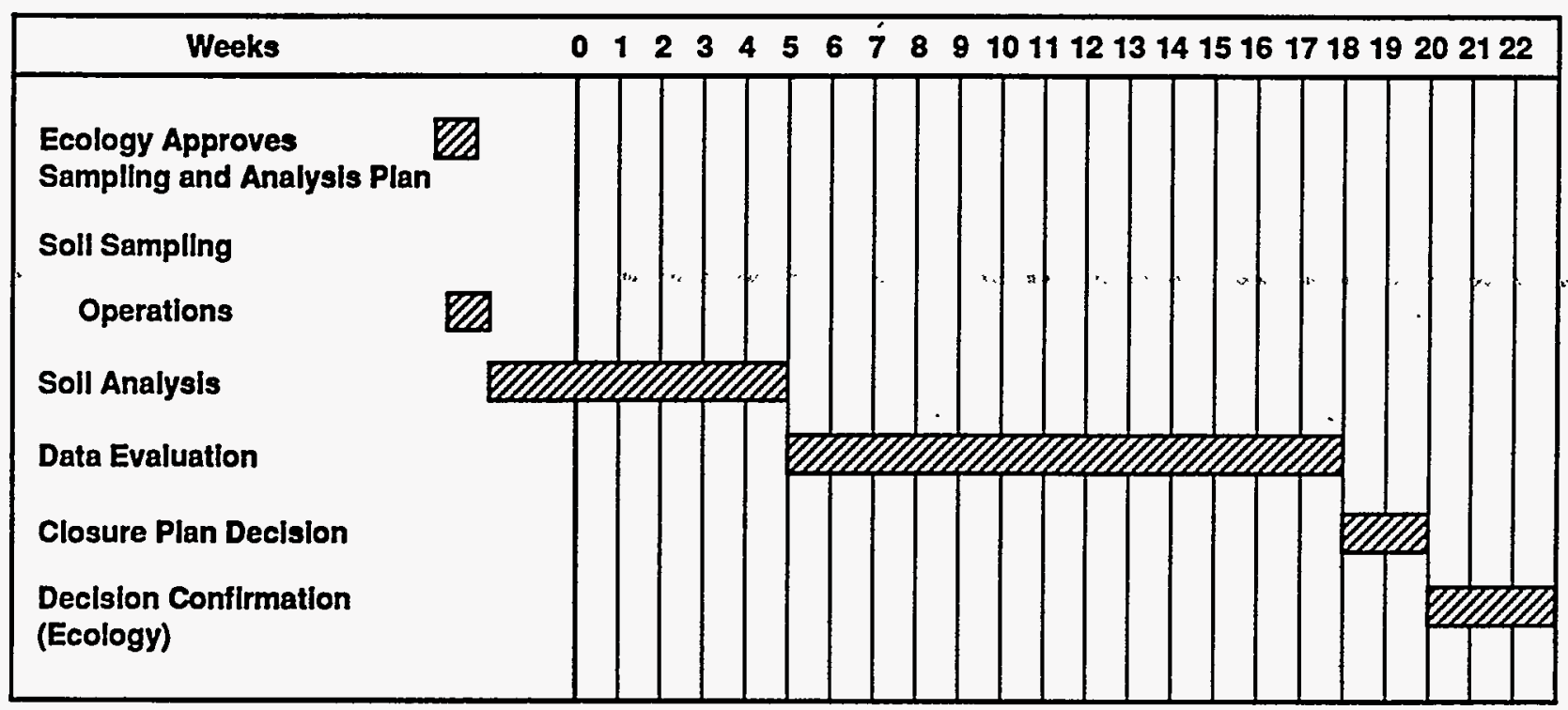

H9209024.1a

Figure 7-1. Hanford Patrol Academy Demolition Sites Closure Schedule. 


\section{CLOSURE CERTIFICATION}

FOR

\section{Hanford Site \\ ע. S* Department of Energy, Richland Operations Office}

We, the undersigned, hereby certify that all closure activities were performed in accordance with the specifications in the approved closure plan.

$$
\text { P.E.\# }
$$
of signature)

Figure 7-2. Typical Closure Certification Document. 
2

4

5

6

CONTENTS

8.0 POSTCLOSURE PLAN ..................... 8-1

8.1 NOTICE IN THE GENERAL INDEX .............. 8-1

8.2 POSTCLOSURE CARE ................ 8-2 
DOE/RL-92-39, Rev. 1

$12 / 15 / 94$

1
2
3
4
5

This page intentionally left blank. 


\subsection{POSTCLOSURE PLAN}

In the event that the HPADS cannot be clean closed and that residual soil contamination remains after soil removal activities, a postclosure permit application for the HPADS will be submitted in accordance with WAC 173-303 regulations.

\subsection{NOFTCE IN THE GENERAL INDEX}

This closure plan proposes that the HPADS be closed with no residual soil contamination that would pose a threat to human health or the environment. However, if clean closure cannot be secured, the following action will be taken in accordance with WAC 173-303-610(1)(b). Within 60 days of the certification of closure, the DOE-RL will sign, notarize, and file for recording the notice indicated below. The notice will be sent to the Auditor of Benton County, P.0. Box 470, Prosser, Washington, with instructions to record this notice in the General Index.

\section{TO WHOM IT MAY CONCERN}

The United States Department of Energy, Richland Operations Office, an operations office of the United States Department of Energy, which is a department of the United States Government, the undersigned, whose local address is the Federal Building, 825 Jadwin Avenue, Richland, Washington, hereby gives the following notice as required by 40 CFR 265.120 and WAC 173-303-610(10) (whichever is appiicable):

(a) The United States of America is, and since April 1943, has been in possession in fee simple of the following described lands: (legal description of the Hanford Patrol Academy Demolition Site)

(b) The United States Department of Energy, Richland Operations Office, by operation of the Hanford Patrol Academy Demolition Sites, has disposed of hazardous and/or dangerous waste under other terms of regulations promulgated by the United States Environmental Protection Agency and the Washington State Department of Ecology (whichever is applicable) at the above described land

(c) The future use of the above described land is restricted under terms of 40 CFR 264.117(c) and WAC 173-303-610(7)(d) (whichever is applicable)

(d) Any and all future purchasers of this 1 and should inform themselves of the requirements of the regulations and ascertain the amount and nature of waste disposed of on the above property 
(e) The United States Department of Energy, Richland Operations Office has filed a survey plat with the Benton County Planning Department and with the United States Environmental Protection Agency, Region 10, and the Washington State Department of Ecology (whichever are applicable) showing the location and dimensions of the Hanford Patrol Academy Demolition Sites and a record of the type, location, and quantity of waste treated.

\subsection{POSTCLOSURE CARE}

Postclosure care is required when a TSD unit has residual contamination that poses a problem to human health or the environment. At the HPADS, underlying soils and possibly groundwater might have been contaminated by waste treated during HPADS operations. Under the Tri-Party Agreement, source contamination and groundwater operable units will be investigated and remediated under the RPP RCRA field investigation/corrective measure study process.

With the general exception of an imminent environmental hazard, any extensive soil remediation will take place under the RPP RCRA field investigation/corrective measure study process. While awaiting remediation under the RPP process, some level of RCRA monitoring might be necessary to ensure that the HPADS poses no threat to human health or the environment. The scope of the monitoring would be limited to contaminated soil that would pose a threat to human health or the environment. The HPADS might not be considered closed until the remediation under the RPP process is complete. Before any soil remediation under RPP, steps might be taken to isolate any contamination. The exact nature of these steps would be determined at the time the need was identified, and this information would be added to the closure plan. In addition, access to the areas of contamination would be controlied to protect personnel and prevent the migration of contamination.

During the period between closure of the HPADS and soil remediation under RPP, the closure areas would be inspected yearly at a minimum. The inspections would determine the need for maintenance of any temporary covers or other physical barriers. Any required maintenance would be performed by Hanford Site personnel.

Any data obtained from sampling and analyses during RCRA closure activities will be part of the official record and will be included in the closure plan. These data will be taken into account and used during the RPP evaluation of the SWMU, as well as any data collected specifically for the RPP evaluation. 
1

2

4

5

6

\section{CONTENTS}

9.0 REFERENCES ....................... 9-1

9.1 DOCUMENTS ....................... . . . . . . . .

9.2 CODE OF FEDERAL REGULATIONS AND FEDERAL REGISTER . . . . 9-3

$9.3 \ldots$ FEDERAL AND STATE ACTS . . . . . . . . . . . . . $9-4$

9.4 REVISED CODE OF WASHINGTON AND WASHINGTON

ADMINISTRATIVE CODE .................. 9-4

9.5 U.S. DEPARTMENT OF ENERGY ORDERS . . . . . . . . . . 9-4 
DOE/RL-92-39, Rev. 1

$12 / 15 / 94$

1
2
3
4
5

This page intentionally left blank. 


\subsection{REFERENCES}

\subsection{DOCUMENTS}

Bjornstad, B. N., K. R. Fecht, and A. M. Tallman, 1987, Quaternary Stratigraphy of the Pasco Basin Area, South-Central Washington, RHO-BW-SA-563A, Rockwe11 Hanford Operations, Richland, Washington.

Davis, T... L., 1943, The Chemistry, of Powder and Explosives, Angriff Press, Hollywood, Cal ifornia.

DOE, 1987, Final Environmental Impact Statement: Disposal of Hanford Defense High-Level, Transuranic and Tank Wastes, Vo1. 1-5, D0E/EIS-0113, U.S. Department of Energy, Washington, D.C.

DOE-RL, 1988a, Draft Remedial Investigation/Feasibility Study Work P7an for the 1100-EM-1 Operable Unit Hanford Site, Richland, Washington, DOE/RL 88-23, U.S. Department of Energy, Richland Operations Office, Richl and, Washington.

DOE-RL, 1988b, Hanford Facility Dangerous Waste Part A Permit Application, DOE/RL-88-21, Vols. 1-3, U.S. Department of Energy, Rich7and Operations Office, Richiand, Washington.

DOE-RL, 1993, Hanford Site Background: Part 1, Soil Background for Nonradioactive Analytes, DOE/RL-92-24, U.S. Department of Energy, Richland Operations Office, Richland, Washington.

DOE-RL, 1994a, 218-E-8 Borrow Pit Closure P7an, DOE/RL-92-53, U.S. Department of Energy, Richland Operations Office, Richland, Washington.

DOE-RL, 1994b, 200 West Ash Pit Closure Plan, DOE/RL-92-54, U.S. Department of Energy, Richland Operations Office, Richland, Washington.

Ecology, EPA, and DOE, 1994, Hanford Federal Facility Agreement and Consent Order, 2 vol., as amended, Washington State Department of Ecology, U.S. Environmental Protection Agency, and U.S. Department of Energy, 01 ympia, Washington.

EPA, 1980, Interim Guidelines for Preparing Quality Assurance Project Plans,EPA-QAMS-005/80, U.S. Environmental Protection Agency, Washington, D.C.

EPA, 1989, Integrated Risk Information System Database, as revised, Dialcom, U.S. Environmental Protection Agency, Silver Springs, Maryland.

EPA, 1990, Test Methods for the Evaluation of Solid Waste: Physical/Chemical Methods, SW-846, as amended, (Supplement 1990) U.S. Environmental Protection Agency, Washington, D.C. 
ICF, 1987, Geohydrologic Study of North Richland Well Field and Groundwater Recharge Basins, principal contributors C. W. Miller, J. G. Bush, and F. W. Bond, prepared by ICF Northwest for the City of Richland, Richland, Washington.

Leonhart, L. S., 1979, Surface Hydrologic Investigations of the Columbia Plateau Region, Washington, RHO-BWI-ST-6, Rockwell Hanford Operations, Richland, Washington.

Lindbefg, J. W., and F.. W. Bond, 1979., Geohydrology and Groundwater Qua.Jity. Beneath the 300 Area, Hanford Site, Washington, PNL-2949, Pacific Northwest Laboratory, Richland, Washington.

Mullịneaux, D. R., 1986, "Summary of Pre-1980 Tephra-fa11 Deposits Erupted from Mount St. Helens, Washington State", U.S.A., Bulletin of Volcanology, v. 48, pp. 17-26.

Newcomb, R. C., 1958, "Ringold Formation of Pleistocene Age in Type Locality, the White Bluffs, Washington, "American Journal of Science, Vol. 33, No. 1 , pp. 1-18.

Newcomb, R. C., J. R. Strand, and F. J. Frank, 1972, Geology and Ground-Water Characteristics of the Hanford Reservation of the U.S. Atomic Energy Commission, Washington, Professional Paper 717, U.S. Geological Survey, Washington, D.C.

Rockhold, M. L., M. J. Fayer, G. W. Gee, and M. J. Kanyid, 1990, Natural Groundwater Recharge and Water Balance at the Hanford Site, PNL-7215, Pacific Northwest Laboratory, Richland, Washington.

Smoot, J. L., J. E. Szecsody, B. Sagar, G. W. Gee, and C. T. Kincaid, 1989, Simulations of Infiltration of Meteoric Water and Containment Plume Movement in the Vadose Zone at Single Shell Tank 241-T-106 at the Hanford Site, HHC-EP-0332, Westinghouse Hanford Company, Richland, Washington.

WHC, 1988a, Environmental Investigations and Site Characterization Manua7, WHC-CM-7-7, Westinghouse Hanford Company, Rich7and, Washington.

WHC, 1988b, Quality Assurance Manua7, WHC-CM-4-2, Westinghouse Hanford Company, Richi'and, Washington.

WHC, 1988c, Radiation Protection, WHC-CM-4-10, Hestinghouse Hanford Company, Richland, Washington.

WHC, 1989a, Document Contro7 and Records Management Manual, HHC-CM-3-5, Hestinghouse Hanford Company, Richland, Washington.

WHC, 1989b, Hanford Patrol Firing Range Safety Assessment Document, WHC-SD-SEC-SAR-00001, Westinghouse Hanford Company, Richland, Washington. 
WHC, 1990a, Environmental Engineering, Geotechnology, and Permitting Function Quality Assurance Program P7an, WHC-EP-0383, Westinghouse Hanford Company, Richland, Washington.

WHC, 1990b, Sample Management and Administrative Manual, WHC-CM-5-3, Westinghouse Hanford Company, Richland, Washington.

WHC, 1991a, Characterization and Use of Soil and Groundwater Background for the Hanford Site, WHC-MR-0246, Westinghouse Hanford Company, Richland, Hashington.

WHC, 1991b, Site-wide Background Soil Samp7ing P7an, WHC-SD-EN-AP-052, Westinghouse Hanford Company, Richland, Washington.

WHC, 1993, Data Validation Procedures for Chemical Analyses, WHC-SD-EN-SPP-002, Westinghouse Hanford Company, Richland, Washington.

\subsection{CODE OF FEDERAL REGULATIONS AND FEDERAL REGISTER}

29 CFR 1910, "Occupational Safety and Health Standards," Tit7e 29, Code of Federal Regulations, Part 1910, as amended, Occupational Safety and Health Administration, Washington, D.C.

40 CFR 261, "Identification and Listing of Hazardous Waste," Title 40, Code of Federal Regulations, Part 261, U.S. Environmental Protection Agency, Washington, D.C.

40 CFR 262, "Standards Applicable to Generators of Hazardous Waste," Title 40, Code of Federal Regulations, Part 262, as amended, U.S. Environmental Protection Agency, Washington, D.C.

40 CFR 264, "Standards for Owners and Operators of Hazardous Waste Treatment, Storage, and Disposal Facilities," Title 40, Code of Federal Regulations, Part 264, U.S. Environmental Protection Agency, Washington, D.C.

40 CFR 265, "Interim Status Standards for Owners and Operators of Hazardous Waste Treatment, Storage, and Disposal Facilities," Title 40, Code of Federal Regulations, Part 265, as amended, U.S. Environmental Protection Agency, Washington, D.C.

40 CFR 270, "EPA Administered Permit Programs: The Hazardous Waste Permit Program," Tit7e 40, Code of Federal Regulations, Part 270, as amended, U.S. Environmenta7 Protection Agency, Washington, D.C.

49 CFR 172, "Hazardous Materials Tables and Hazardous Materials Communications Requirements and Emergency Response Information Requirements, "Title 49, Code of Federal Regulations, Part 172, as amended, U.S. Department of Transportation, Washington, D.C. 
49 CFR 173, "Shippers-General Requirements for Shipments and Packaging," Title 49, Code of Federal Regulations, Part 173, as amended, U.S. Department of Transportation, Washington, D.C.

49 CFR 178, "Shipping Container Specification," Title 49, Code of Federal Regulations, Part 178, as amended, U.S. Department of Transportation, Washington, D.C.

49 CFR 179, "Specifications for Tank Cars," Title 49, Code of Federal Regulations, Part 179, as amended, U.S. Department of Transportation, Washington, D.C.

\subsection{FEDERAL AND STATE ACTS}

Atomic Energy Act of 1954, 42 USC 2011 et seq.

Comprehensive Environmental Response, Compensation, and Liability Act of 1980, 42 USC 9601 et seq.

Resource Conservation and Recovery Act of 1976, 42 USC 6901 et seq.

State of Washington Hazardous Waste Management Act of 1976, Revised Code of Washington, Chapter 70.105 et seq., 01 ympia, Washington.

\subsection{REVISED CODE OF WASHINGTON AND WASHINGTON ADHINISTRATIVE CODE}

WAC 173-303, Dangerous Waste Regulations, Washington State Department of Ecology, Olympia, Washington.

WAC 173-340, Model Toxics Control Act Cleanup Regulations, as amended, Washington State Department of Ecology, Olympia, Washington.

\subsection{U.S. DEPARTMENT OF ENERGY ORDERS}

5400.1, General Environmental Protection Program Requirements. 
DOE/RL-92-39, Rev. 1

$12 / 15 / 94$

1

APPENDIX 2A

2
3
4

PHOTOGRAPHS 
DOE/RL-92-39, Rev. 1

$12 / 15 / 94$

1

2

3

This page intentionally left blank. 


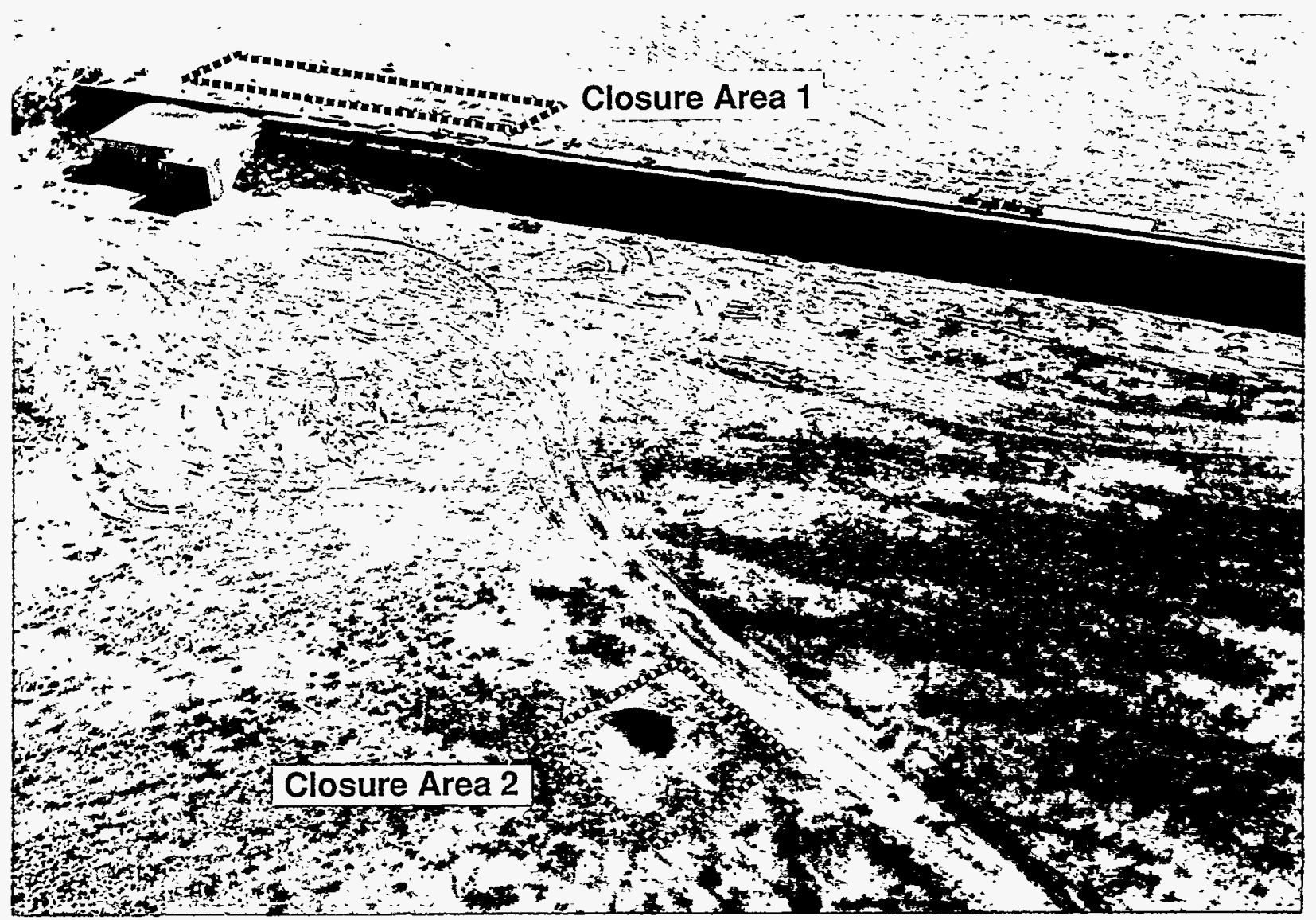




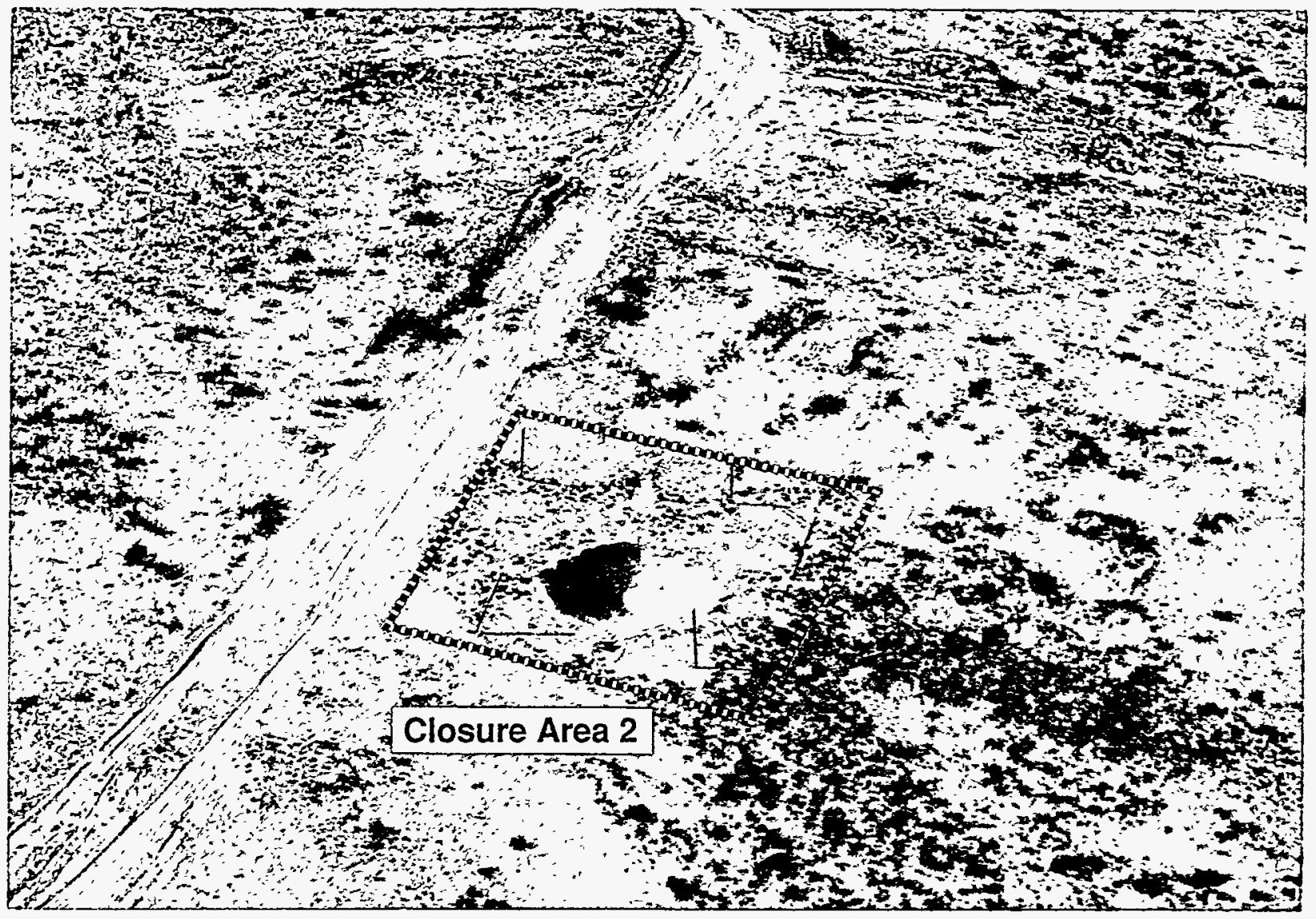


DOE/RL-92-39, Rev. 1

$12 / 15 / 94$ 
DOE/RL-92-39, Rev. 1

12/15/94

2

4

5

This page intentionally left blank. 


\section{HANFORD ENVIRONMENTAL}

HEALTH FOUNDATION

September 4, 1990

CO\# 15711

Westinghouse Hanford Company

MSIN R2-82

Attn: K.A. Ayster

SOIL ANALYSIS

The results of the analyses performed on the two soil samples received June 21 , 1990, are tabulated below. These samples were reportedly from the detonation pit.

The samples were anlayzed for 1,3,5-trinitrobenzene (TNB), total lithium, and total aluminum. The analyses were performed by ATI in accordance with approved protocols.

\begin{tabular}{|c|c|cc|c||}
\hline Sample ID & $\begin{array}{c}\text { Sample } \\
\text { Description }\end{array}$ & \multicolumn{2}{|c|}{$\begin{array}{c}\text { Total Metals } \\
\mathrm{mg} / \mathrm{Kg}\end{array}$} & \multicolumn{2}{c|}{$\begin{array}{c}\text { Organics } \\
\mathrm{mg} / \mathrm{Kg}\end{array}$} \\
\hline Det-90-01-A & Sandy Soil & $\begin{array}{r}5970 \\
8.6\end{array}$ & $\begin{array}{c}\text { Aluminum } \\
\text { Lithium }\end{array}$ & $<0.34 \quad 1,3,5-$ TNB \\
\hline Det-90-01-B & Sandy Soil & $\begin{array}{r}6220 \\
8.1\end{array}$ & $\begin{array}{c}\text { Aluminum } \\
\text { Lithium }\end{array}$ & $<0.17 \quad 1,3,5-$ TNB \\
\hline
\end{tabular}

Your samples are being returned to you for disposal.

If you have any questions regarding this report, please contact Environmental Health Sciences.

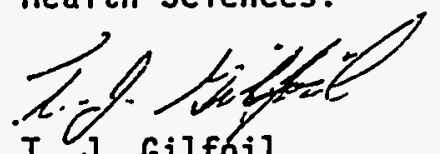

T. J. Gilfóil

Environmental Health Sciences

$\mathrm{kW}$ 
OIL \& HAZARDOUS WASTE ANALYSIS REQUEST FORM

(Samples will not be accepted with out a 71 necessary,

REQUESTOR properly completed paper work saingli $x$ D $+-90-01-\infty$

Name 1 C.A. Ayster Company witc BTdg/Area 2550 E-200E Phone $\frac{3-5075}{2-85}$ Work Order $M_{L} 82 E$ MSIN $\frac{12-82}{22}$

SAMPLE CONTAIMERS - Al1 oils and organic samples shall be submitted in giass containers with teflon-lined caps. Other samples shall be submitted in containers appropriate for the requested analyses. Consult HEHF Tab (6-6980) for assistance in container selection and sample quantity requirements.

\section{SAMPLE DESCRIPTION}

Sampling Location Pctonation Plf

Method of Sampling Glass tubing

Coliwasa

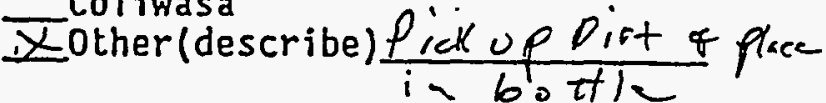

\section{Type of Container} $55 \mathrm{gal}$. drum

- Transformer Hydraulic System Zother(describe) Gless bottic

Description of material sampled (Label information, transformer original use, drum \#, suspected concentrations etc) Soil from thic. detor-tion $P$ is

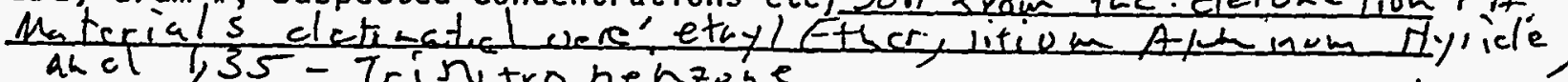

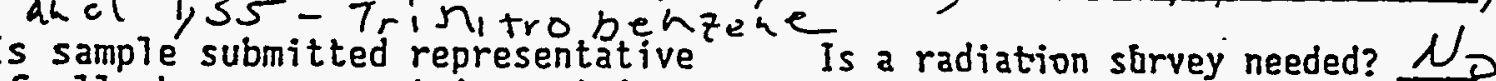
of a 71 phases present in container sampled? $/ 25$ If "yes": external only : external \& internal

\section{CHAIII OF CUSTODY}

(Copy of all survey data must be attached)

Sampled by J.W. O/s on

Date Sampled 6-7-q5

Date Relinquished $6-1-90$

shipped by 2,4 . Aster

Date Received o-7-90

Date Relinquished $6-21-90$
Received by $x+A$, hyser

Date Received $6-X-\xi 0$

Date Relinquished

Received for Lab

Date Received

Storage Location

\section{REQUESTED ANALYSES}

PCBs Required Detection Limit:

Ignitability (Flash Point)

Halogenated Hydrocarbons

Corrosivity:

EP Toxicity:

Other Metals (7ist)

Solvent ID by GCMS

Other Analys is (Specify) Ethy $E+$ Reactivity

$2 \mathrm{ppm}$ Steel Corrosion 8 Metals _Pesticides

\section{st)}

other Analysis (Specify) Ethyl EtLo

REPORTING DEADLINE

Does sample have $90 /$ day clock

running or other compliance deadline? No

if yes, clock start date or compliance due date If no, desired due date
SEND REPORT TO

Name $\frac{1 C, 14, A Y 6 \text { ter }}{122-\delta Z}$

RETURN SAMPLE TO

Name $M \cdot R, R o$ insos

Bldg 2750 E Area $200 E$ 
OIL \& IIAZARDOUS HASTE. ANALYSIS REQUEST FORM

(Samples will not be accepted with out ali necessary,

REQUESTOR properly completed paper work)

Name K. A. Ayster Company $\omega H c$

Bldg/Area 275iE/200E Phone 3-5015

Work Order $M L 82 \epsilon$ MSIN $\frac{32-82}{R 2}$

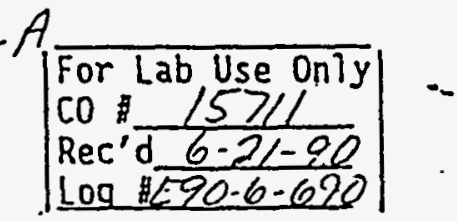

SAMPLE CONTAIIERS - Al1 oils and organic samples shall be submitted in giass containers with teflon-7ined caps. Other samples shalt be submitted in containers appropriate for the requested analyses. Consult HEHF Tab (6-6980) for assistance in container selection and sample quantity requirements.

\section{SAIYPLE OESCRIPTION}

Samping Location Detonation Pit

Type of Container

55 gal. drum

Method of Sampling Glass tubing * Other(describe)fick up dirt y दि́r in Bothe. Transformer Xother(describe) Hydraulic System $6 / 455$ soth

Description of material sampled (Label information, transformer original use, drum $\#$, suspected concentrations etc) Soli from the detoration $p$ ito Materials detonated werei ethylether, litium aluminum Hyciride and 1,3,5-trin itrolsenzene.

Is sample submitted representative is a radiation survey needed? NO of all phases present in container If "yes": external only sampled? yes : external \& internal

CHAII OF CUSTODY

(Copy of all survey data must be attached)

Sampled by J.W. J150n Date Sampled $6-7-90$

Date Retinquished $6-7-90$

Shipped by K.CA. Ayster Date Received 6-7-790

Date Relinquished $6-21-90$
Received by $1 C, A$. Ayster Date Received $6-7-90$

Date Relinquished.

Received for Lab

Date Received

Storage Location

\section{REQUESTED ANALYSES}

PCBs Required Detection Limit: $2 \mathrm{ppm}$ $1 \mathrm{ppm} \quad 0.05 \mathrm{ppm} \quad$ other Ignitability (Flash Point) 0 il Metals (As, $\overline{\mathrm{Cd}}, \mathrm{Cr}, \mathrm{Pb}$ ) Halogenated Hydrocarbons Corrosivity: $\mathrm{pH}$ Steel Corrosion EP Toxicity: 8 Metals _ Pesticides Other Metals (Tist) Solvent ID by GCMS - Reactivity Polynuclear Aromatics. (PAHs) Anions $\left(\mathrm{F}, \mathrm{Cl}, \mathrm{NO}_{3}, \mathrm{NO}_{2}, \mathrm{PO}_{4}, \mathrm{SO}_{4}\right)$ Basic cations ( $\mathrm{Na}, \mathrm{R}, \mathrm{NH}_{3}$ ) Glycols

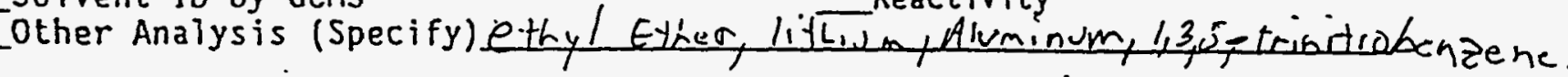

\section{REPORTING DEAOLIHE'}

Boes sample have 90 day clock running or other compliance deadline?

if yes, clock start date or compliance due date if no, desired due date

\section{SEND REPORT TO}

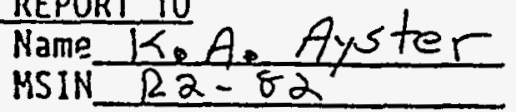

RETURN SAMPLE TO

$$
\text { Name } \frac{m x}{20} \text {. Rom }>0 S
$$

BIdg 2750 Area $200 E$ 


\section{HANFORD ENVIRONMENTAL}

\section{HEALTH FOUNDATION}

February 26, 1990

CO 14242

Westinghouse Hanford Company

MSIN D2-65

Attn: M. R. Romsos

WASTE CHARACTERIZATION - OEMOLITION-SIIE SOIL

The following are the results of the analysis of the soil sample received July 21 , 1989. This sample was reportedly soil from the demolition site at the Patrol Academy. The purpose of the analysis was to look for residual contamination from the materials detonated during the last year.

Benzene was determined on a methanol extract of the soil in accordance with USEPA methods 8021 and 5030 (SW-846, 3rd Ed.) using purge and trap followed

, by gas chromatography with photoionization detection. 1,4-Dioxane was determined on the same methanol extract using direct injection into a gas chromatograph with $f l$ ame ionization detection.

The remaining analyses were done by Analytical Technologies, Inc. Hydrazine was determined colorimetrically in accordance with ASTM D1385. A semivolatiles GC/MS scan was done following EPA method 8270 (SH-846, 2nd Ed.). The purpose of this scan was to look for nitrophenols and other possible combustion products. The complete list of compounds scanned is attached.

Sample ID

DET-89-04
Analytical Results

$<0.125 \mathrm{mg} / \mathrm{Kg}$ benzene

$<5 \mathrm{mg} / \mathrm{Kg} \mathrm{l,4-dioxane}$

$0.084 \mathrm{mg} / \mathrm{Kg}$ hydrazine

No 2,4-dinitrophenol or other semivolatiles noted (see attached for compound 7 ist and detection limits)

Your sample is being returned to you for disposal.

If you have any questions regarding this report, please contact Environmental Health Sciences.

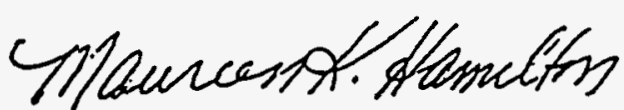

M. K. Hamilton, CIH

Laboratory Director

Environmental Health Sciences

cc: J. Kessner, OSM, T6-08 
- 2 AnolylicolTechnologies, Ine.

GCAS - RESULTS

ATI I.D. : 00216801

.EST : EPA 3270 (GC/MS FOR SEMIVOLATIIE ORGANICS)

$\begin{array}{llll}\text { CLIENT } & : \text { HANFORD ENVIRONMENTAL HEALTH FND. } & \text { DATE SAMPLED } & : 01 / 26 / 9 C \\ \text { PROJECT } & : \text { MSD-STB-431842 } & \text { DATE RECEIVED } & : 01 / 30 / 90 \\ \text { PROJECT NAME } & : \text { WASTE ANALYSIS } & \text { DATE EXTRACTED }: 02 / 15 / 90 \\ \text { CLIENT I.D. } & : \text { E89-7-466 } & \text { DATE ANALYZED } & : 02 / 20 / 90 \\ \text { SAMPLE MATRIX } & : \text { SOIL } & \text { UNITS } & : \text { MG } / \mathrm{KG}\end{array}$

COMPOUNDS.

N-NITROSODIMETHYIAMINE

PHENOL

ANILINE

BIS (2-CHIOROETHYL) ETHER

2-CHLOROPHENOI

1,3-DICHLOROBENZENE

I, 4-DICHLOROBENZENE

BENZYL ALCOHOL

1,2-DICHLOROBENZENE

2-METHYLPHENOL

BIS (2-CHLOROISOPROPYI) ETHER

4-METHYIPHENOI.

N-NITROSO-DI-N-PROPYIAMINE

XACHLOROETHANE

.TROBENZENE

ISOPHORONE

2-NITROPHENOL

2,4-DIMETHYIPHENOI

BENZOIC ACID

BIS (2-CHLOROETHOXY) METHANE

2, 4-DICHLOROPHENOI

2, 2,4-TRICHLOROBENZENE

NAPHTHALENE

4-CHLOROANILINE

HEXA.CHIOROBUTADIENE

4-CHLORO-3-METHYIPHENOL

2-METHYLNAPHTHALENE

HEXACHLOROCYCIOPENTADIENE

$2,4,6$-TRICHIORQPHENOI

$2,4,5$-TRI CHLOROPHENOI

2-CHLORONAPHTHALENE

2-NITROANILINE

DIMETHYI PHTHALATE

ACENAPHTHYLENE

3-NITROANILINE

ACENAPHTHENE

2, 4-DINITROPHENOL

ITROPHENOL ENZOFURAN

$<, 4$-DINITROTOLUENE

,6-DINITROTOIUENE

UIETHYLPHTHALATE

\section{RESUETS}

$<0.17$

$<0.17$

$<0.17$

$<0.17$

$<0.17$

$<0.17$

$<0.17$

$<0.17$

$<0.17$

$<0.17$

$<0.17$

$<0.17$

$<0.17$

$<0.17$

$<0.17$

$<0.17$

$<0.17$

$<0.17$

$<0.85$

$<0.17$

$<0.17$

$<0.17$

$<0.17$

$<0.17$

$<0.17$

$<0.17$

$<0.17$

$<0.17$

$<0.17$

$<0.85$

$<0.17$

$<0.85$

$<0.17$

$<0.17$

$<0.85$

$<0.17^{\circ}$

$<0.85$

$<0.85$

$<0.17$

$<0.17$

$<0.17$

$<0.17$ 
$\therefore$ " HAnchticalTechnologies, inc. GCMS - RESUITS

ATI I.D. : 00216801

TEST : EPA 3270 (GC/MS FOR SEMIVOLATIIE ORGANICS)

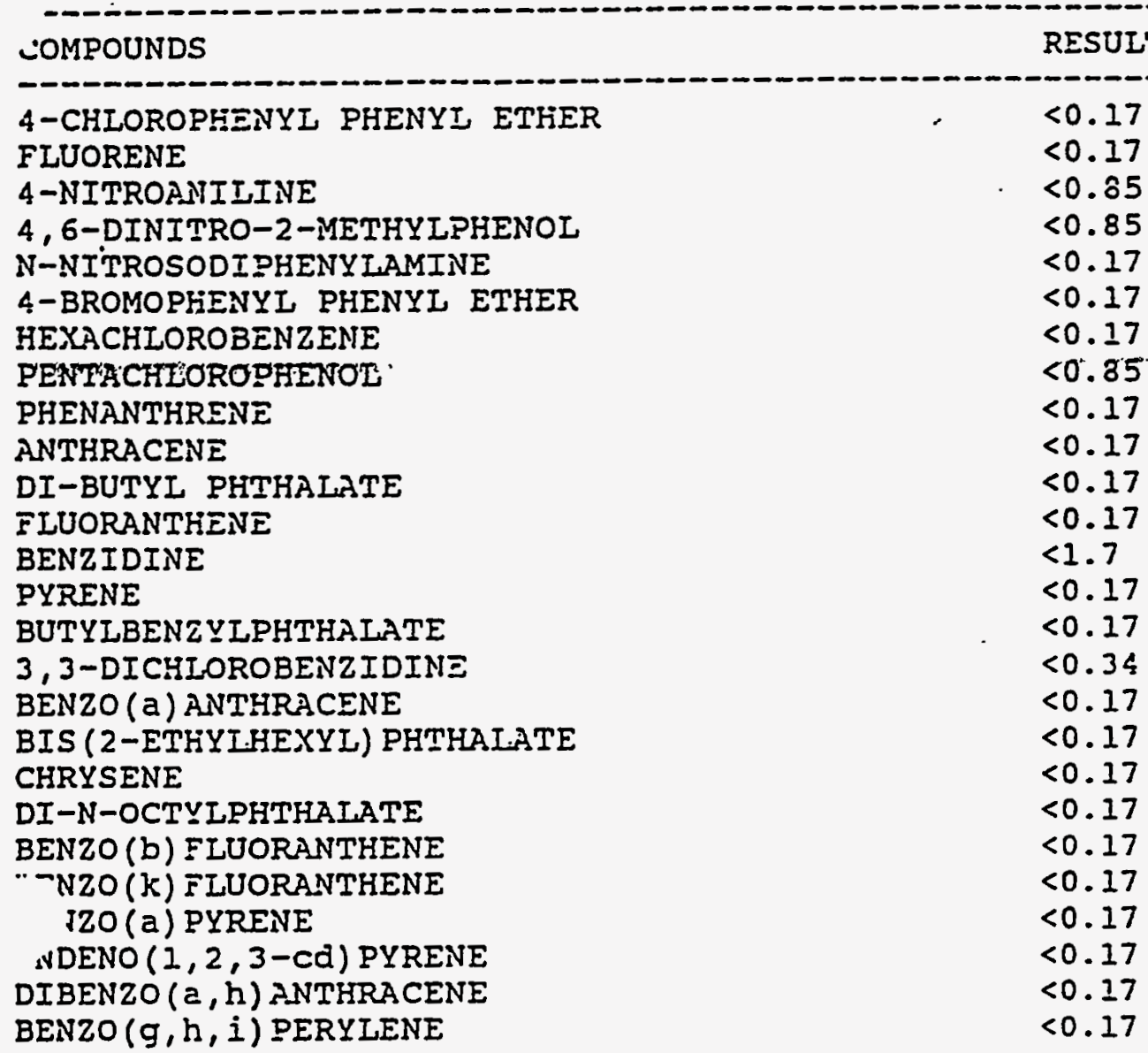

\section{SURROGATE PERCENT RECOVERIES}

NITROBENZENE-D5 (\%)

2-FIUOROBIDUENYL (\%)

TERPHENYI (\%)

PHENOL-D6 (\%)

2-FLUOROPHENOI (\%)

$2,4,6$-TRIBROMOPHENOL (\%)

48

60

71

47

85

61 
Sampling Plan for Patrol Academy Blasting Pit to Determine Extent of Land Banned Contamination to Soit Onsite

A grid will be set up around the blasting pit (see figure 1). It will consist of radials every $45^{\circ}$ aligned to magnetic north $\left(0^{\circ}\right)$ and distances from the pit edge of $10,20,30,40,50,75,100,150$ and 200 feet (the pit is 10 feet in diameter). Seventeen points will be selected from a random number table and numbers 11-19, 21-29, .., 81-89 accepted.

These points, will be plotted on the grid as fallows:

$0^{\circ}$ radial $=1,45^{\circ}$ radial $=2, \ldots, 315^{\circ}$ radial $=8$

200 foot $\operatorname{mark}=1,150$ foot mark $=2, \ldots, 10$ foot mark $=9$

Approximately 4 ounces of soil will be. taken from each point and placed in a large container ( 5 gallon pail or bag). The contents will be thoroughly mixed and two samples taken. The remaining soil will be returned to the ground.

\section{Procedure}

1. Place rod in center of detonation pit

2. Mark distances with tape $(10,20,30,40,50,75,100,150$, and 200).

3. Use a compass to find radial and have assistant walk out with rope to sample distance along radial.

4. Take 4 ounces of soil including topsoil and place in container.

5. Repeat steps 3 and 4 until no more points lie along radial.

6. Move to next radial and repeat steps $3-5$.

7. When completed, mix soil in container well and remove two samples.

8. Pour remaining soif to ground.

9. Mark samples accordingly. 


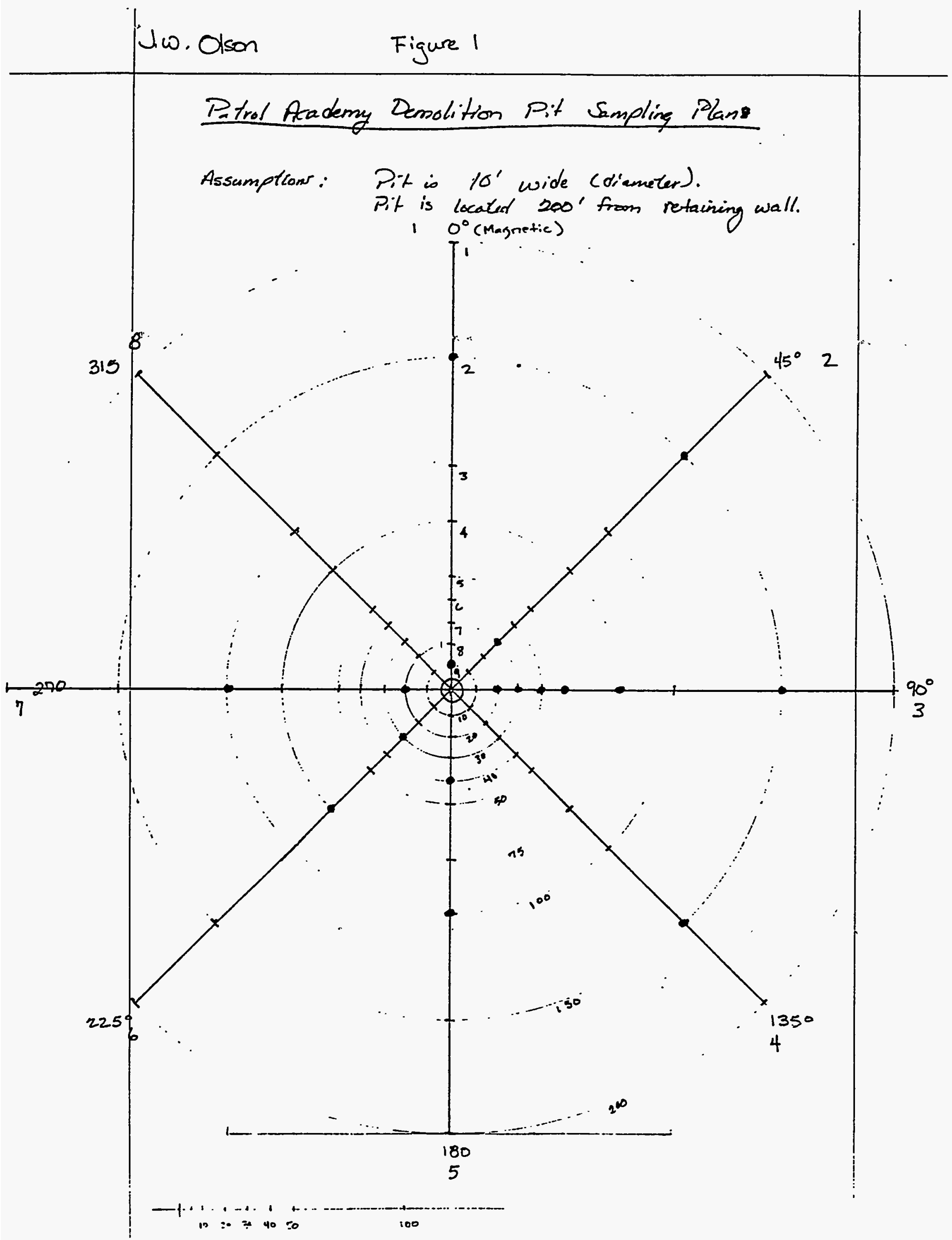


J.w. Olson

Randam Numbers for Sampling Blasting Fit.

samplet RandonNumber

1. 75

2. 67

3. 27

4. 35

5. 53

6. 78

7. 34

8. $\quad 32$

10. 19

11.12

12. 37

$13 . \quad 22$

$14 . \quad 36$

15. 42

16. 56

17. 38 
November 14, 1988

Mr. Mike Romsos

Westinghouse Hanford Company

P.0. Box 1970

RI -.51 .

Richland, Wa. 99352

Dear Mike,

P7ease find the enclosed results for NWES Job \# 12-6355.01.

The soil samples, marked Det 3 and Det 4, were submitted for Picric Acid Analysis.

If you have any questions or need further information, please feel free to call any time.

Sincerely,

Northwest EnviroService, Inc.

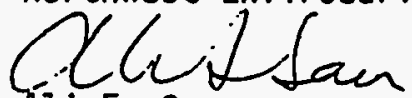

Ár i F. San

Lab Administrator

AFS/ts

Enclosures 


\section{Certificate}

940 South Harney St., Seattle, WA 98108 (206) 767-5060 FAX 767-5063

Chemistry.Microbiology. and Technical Services

CLIENT: Northwest EnviroServices, Inc.

LABORATORY NO. 12325

P.0. Box 24443

Seattle, WA 98124

ATTN: Ali San

DATE: Nov. 11, 1988

PO\# 22919

REPORT ON: SOIL

SAMPLE

IDENTIFICATION: Submitted 09/29/88 and identified as shown below:

1) Sample \#880915 B2

2) Sample $\$ 880915 \mathrm{C2}$

TESTS PERFORMED

AND RESULTS:

parts per million $(\mathrm{mg} / \mathrm{kg})$, dry basis

Picric Acid
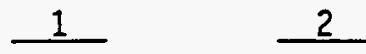

0.50

37.

Respectfuily submitted,

Laucks Testing Laboratories, Inc.

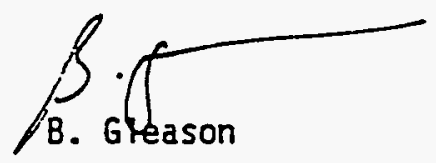

$B G: e m t$

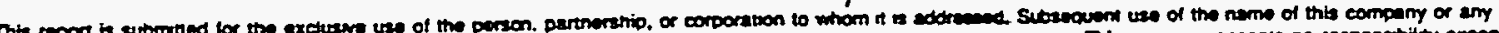

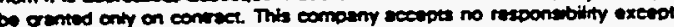

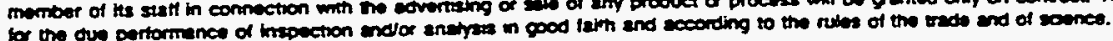


Chemistry. Microbiology, and Technical Services

APPENOIX

Copy of Chain-of-Custody is Attached 
CHAIN OF CUSTODY RECORD DATE $\% / 2 \% / 6 \%$ PAGE $\%$ of 1

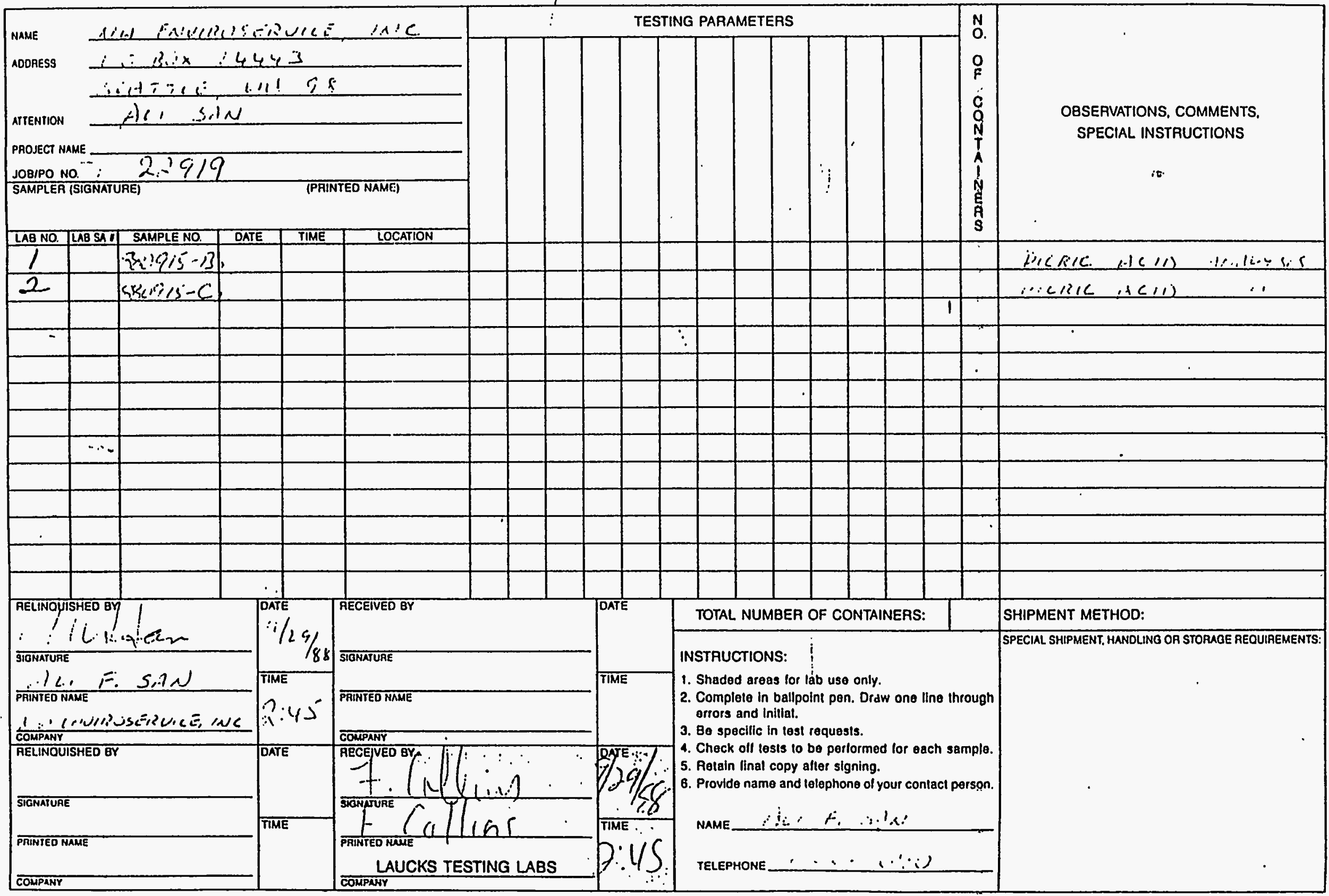


GENERATOR NAME: Westinghouse Hanford

GENERATOR SAMPLE \#: DET-2

ADDRESS :

P.O. Box 1970

WPQ \#:

Richland, :WA 99352 MANIFEST

GENERATOR CONTACT: Mike Romsos

NWES CONTACT:

Joe Nessel

PROJECTED WASTE VOLUME: $x$ DRUMS BULK VOLUME

GALLONS

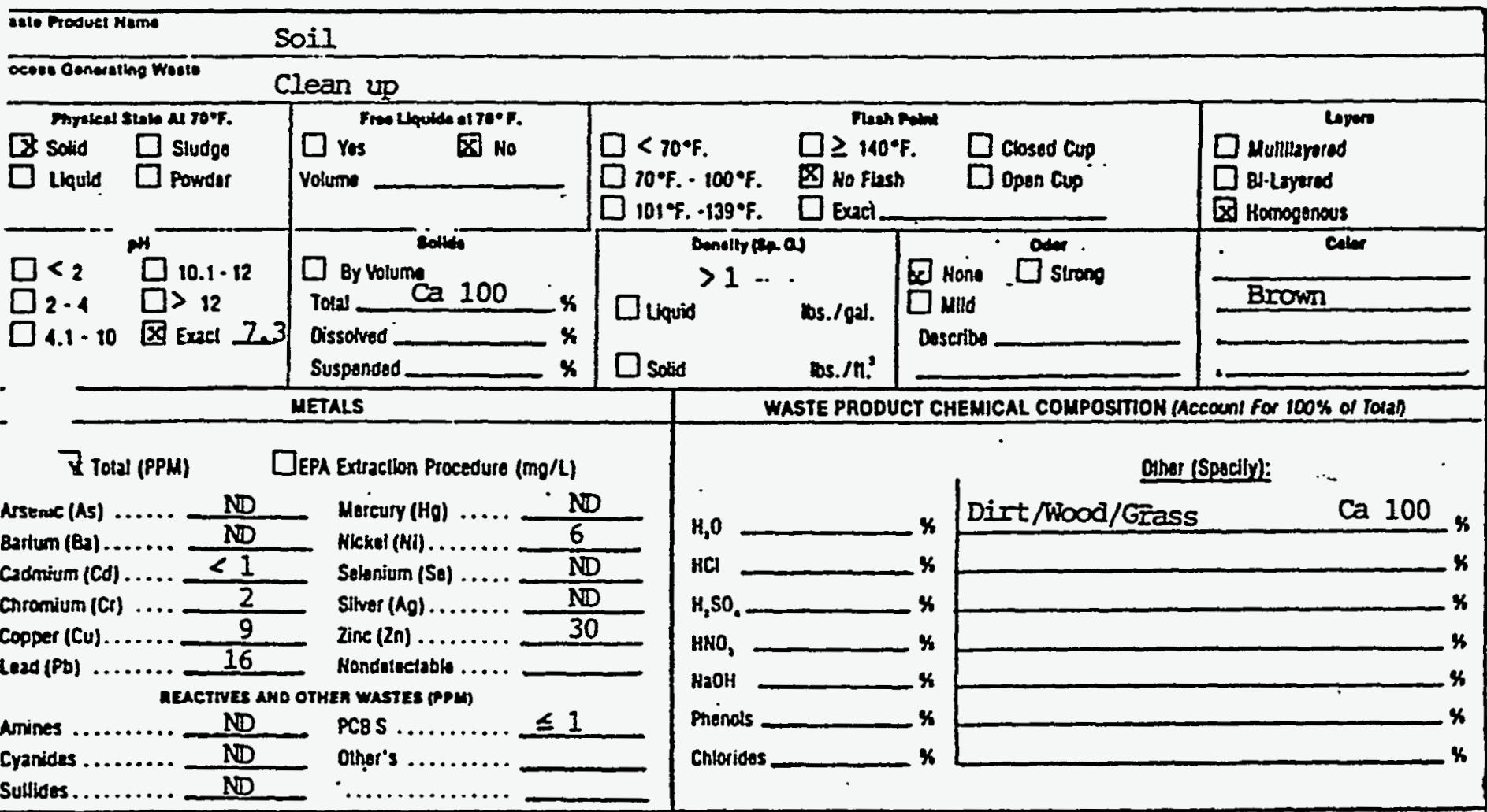

ADUITIONAL TESTS

TEST

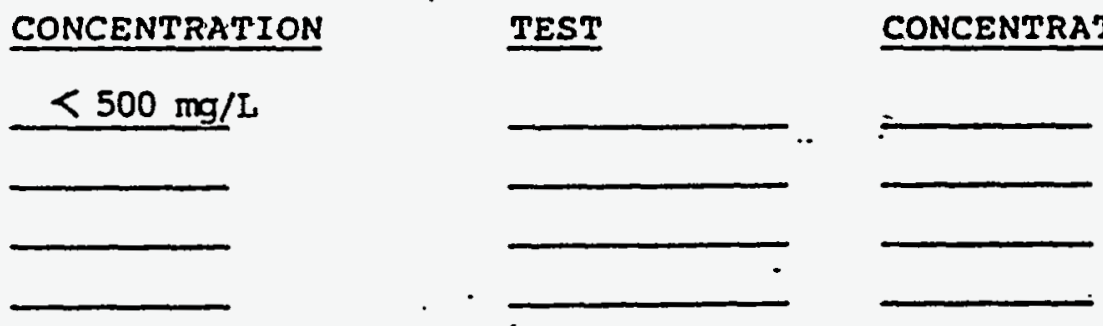

CUMMENTS :

ALYSIS PERFORMED BY: TAR/RB

P.O. Box 24443 • Seattle, WA 98124 • 1500 Airport Way South • Seattle, WA 98134 - Phone (206) 622.1090 
GENERATOR NAME: Westinghouse Hanford

SAMPLE : 870915-T

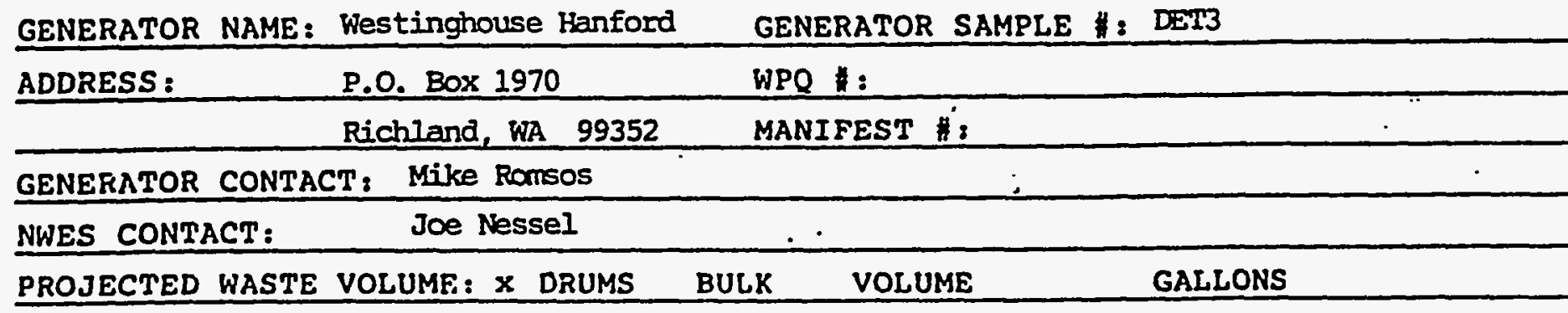

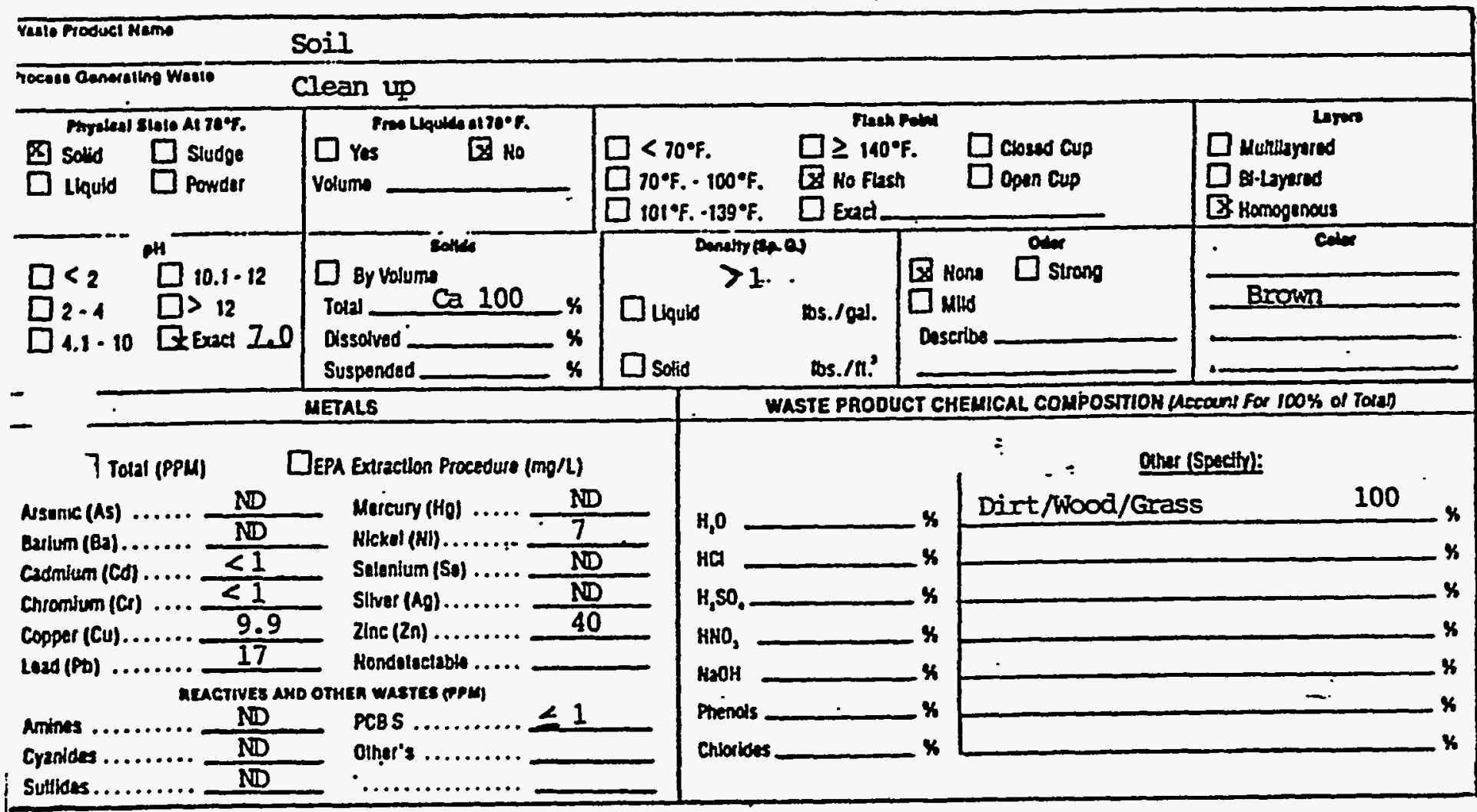

ADUITIONAL TESTS

TEST

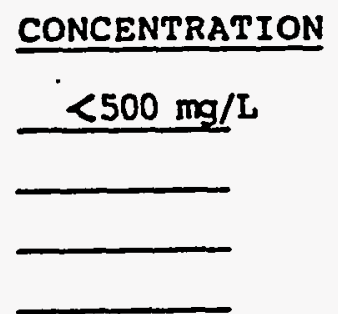

TEST

CONCENTRATION

F-listed Wastes

COMMENTS :

..AALYSIS PERFORMED BY: TAR/RB

P.O. Box 24443 - Seattle, WA 98124 - 1500 Airport Way South • Seattle, WA 98134 - Phone (206) 622-1090 
APPENDIX 3B

HANFORD WEATHER STATION METEOROLOGICAL DATA FOR HANFORD PATROL ACADEMY DEMOLITION SITES DETONATIONS OCCURRING AFTER 1984 
DOE/RL-92-39, Rev. 1

1

2

3

4

5

This page intentionally left blank. 


\begin{tabular}{|c|c|c|c|}
\hline Date & $\begin{array}{l}\text { Wind speed } \\
\text { (miles per hour) }\end{array}$ & Direction & Rain \\
\hline August 16,1984 & 5.2 & W & None \\
\hline October 30, 1985 & 8.2 & $W$ & None \\
\hline March 12, 1987 & 7.2 & SE & $0.42^{\prime \prime}$ \\
\hline August 25,1987 & 4.3 & NE & None \\
\hline December 9, 1987 & 10.4 & SW & $0.55^{\prime \prime}$ \\
\hline June 21, 1988 & 8.0 & $W$ & None \\
\hline December 20, 1988 & 2.9 & NW & $0.13^{\prime \prime}$ \\
\hline February 10, 1989 & 1.2 & NE & None \\
\hline March 2, 1989 & 6.1 & NW & $0.07^{\prime \prime}$ \\
\hline Apri1 26, 1989 & 4.7 & NW & $0.03^{n}$ \\
\hline JuTy 19, 1989 & 6.5 & NW & None \\
\hline June 6,1990 & 4.8 & SW & $0.36^{\prime \prime}$ \\
\hline October 27,1991 & 6.3 & NH & Trace \\
\hline
\end{tabular}


DOE/RL-92-39, Rev. 1

12/15/94

This page intentionally left blank. 
DOE/RL-92-39, Rev. 1

$12 / 15 / 94$

1

APPENDIX 4A

WASTE INVENTORIES

APP $4 A-i$

941117.1416 
DOE/RL-92-39, Rev . 1
12/15/94

This page intentionally left blank. 
:

Project Number

Pacific Northwest Laboratories

Internal Distribution

JMH - File/LB

Date August 27, 1984

To

From

Leonard Lust

Subject

sene Hobbs Geese

CHEMICAL DISPOSAL.

Disposal request approval for APNL-84-004, 25\# of ether, is no ranger needed. This chemical pius 6 quarts of tetrahydrofuran and 7 pints of perchloric acid from $\# P N L-84-007,1 / 2$ pint of perchloric acid from \#PNL-83-020, and $4500 \mathrm{~mL}$ of 2-butoxyethanol from APNL-83-014 were exploded by the Richland Bomb Squad on August 16, 1984. This information is provided to help you update your records.

If you have any questions, please contact me on 376-1361.

$/ s T w$ 
PNL-84-004

I. GENERATION: The Generator should complete Part 1 and forward this form to: WS\&DT 202-S/200 West

Rockwell

A. Generator's Name: Jeene Hobbs

B. Custodian's Name: AT Scott

C. Waste Description:

\begin{tabular}{|c|c|c|c|c|c|c|c|}
\hline \multirow{2}{*}{ Generic Name } & \multirow{2}{*}{$\begin{array}{c}\text { Total } \\
\text { Quantity }\end{array}$} & \multirow{2}{*}{$\begin{array}{l}\text { Type of } \\
\text { Container }\end{array}$} & \multirow{2}{*}{$\begin{array}{l}\text { Number of } \\
\text { Containers }\end{array}$} & \multicolumn{3}{|c|}{ (Check One) } & \multirow{2}{*}{ Hazard Class } \\
\hline & & & & 5ol. & Lía. & Gas & \\
\hline 1. Ether - dated $7: 7 / 80$ & $25 \mathrm{H}^{-}$ & metar? & 25 . & & $x$ & & Flammable" Fiq" \\
\hline 2. (these cans have nev & $r$ been 0 & pened - but & they are & ay $p$ & st & heir & shelflife.) \\
\hline 3. & & & & & & & \\
\hline 4. & & & & & & & \\
\hline 5. & & & & & & & \\
\hline
\end{tabular}

D. Have appropriate labels been affixed to containers?

Not required

E. Have efforts been made to recycle (e.g., excess) waste? NA

F. Has waste been treated in any manner? no If so. how?

G. Storage Location: $332 / 300$ Area

H. "I hereby certify that this material has been released by Radiation Monitoring (if applicable) and that Part One of this form has been completed to the best of my knowledge." Survey Card Number:

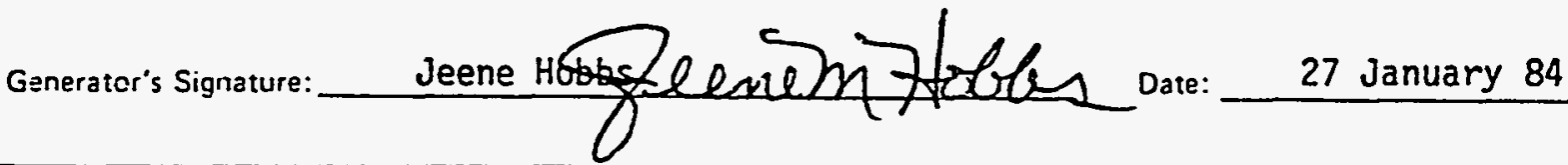

II. APPROVAL

A. Approved for disposal by Name: Phone: Address Co.:

Date: Signature:

B. Packaging Requirements (specify):

C. Disposal Location: (check one) Chemical Trench, 212.P (Storage). Asbestos Trench. Other

11I. TRANSPORTATION/DISPOSAL

A. Transporter(s) Name: Phone: Address: Company

B. Date Trunsported/Disposed:

C. Transporter(s) Signature: 
I. GENERATION: The Generator should complete Part I and forward this form to:

WS\&DT

202.S/200 West

Rockwell

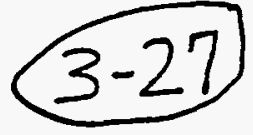

A. Generator's Name: _leene Hobbs___ Phone:_ 6-1631_ Address: 3762 Company: PNL PN

B. Custodian's Name: Jack MeCarthy Phone: Address: $\quad 325$ Company: HEDL

C. Waste Description: (If more than five items, attach additional sheets)

\begin{tabular}{|c|c|c|c|c|c|c|c|}
\hline \multirow{2}{*}{ „ Gẹneric Name } & \multirow{2}{*}{ - Total } & \multirow{2}{*}{$\begin{array}{l}\text { Type of } \\
\text { Contuiner }\end{array}$} & \multirow{2}{*}{$\begin{array}{l}\text { Number of } \\
\text { Conteiners }\end{array}$} & \multicolumn{3}{|c|}{ (Check One) } & \multirow{2}{*}{ Hezard Cless } \\
\hline & & & & Sor: & Liq. & Gas & \\
\hline 1.1,4-dioxane D.W. & $3 \mathrm{pt}$ & 1 ot glass & 3 & & $x$ & & flammable 1 ia \\
\hline 2. nitromethane & $1 \mathrm{pt}$ & glass & T & & $\bar{X}$ & & $n a b l$ \\
\hline 3. methylene chloride & $2 \mathrm{pt}$ & 1 pt glass & 2 & & $x$ & & \\
\hline 4.Anhydrone & 1\# & glass & 1 & & $\underline{X}$ & & \\
\hline 5.2 butoxyethanol & $4500 \mathrm{~m}$ & $500 \mathrm{ml}$ glass & 9 & & $\underline{x}$ & & $\mathrm{Com}$ \\
\hline
\end{tabular}

D. Have appropriate labels been affixed to containers? Not required They will be.

E. Have efforts been made to recycle (e.g., excess) waste? no

$\boldsymbol{F}$. Has waste been treated in any manner? na If so, how?

G. Storage Location: $332 / 300$ Area

H. "I hereby certify that this material has been released by Radiation Monitoring (if applicable) and that Part One of this form has been completed to the best of my knowiedge." Survey Card Number:

Generator's Signature:

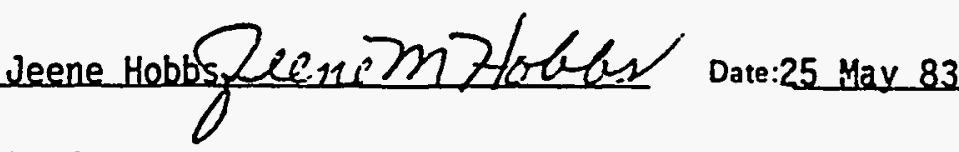

II. APPROVAL

A. Approved for disposal by Name: G,, Cox Date: June 6,1983

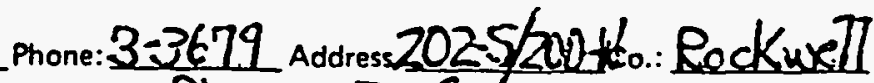
Signature: $\mathrm{QA}=\mathrm{Cox}$

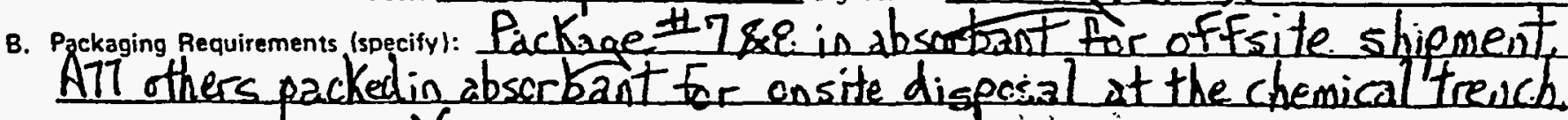

C. Disposal Location: (check one)
Chemical Trench, 212.P (Storage). 2727-5/200+w Other Asbestos Trench. (cifsitestipment)

\section{TRANSPORTATION/DISPOSAL}
A. Transporter(s) Name:
Phone: Address:
B. Date Transported/Disposed:
C. Transporter(s) Signature: Company 
Chemical Waste Disposal Logsheet

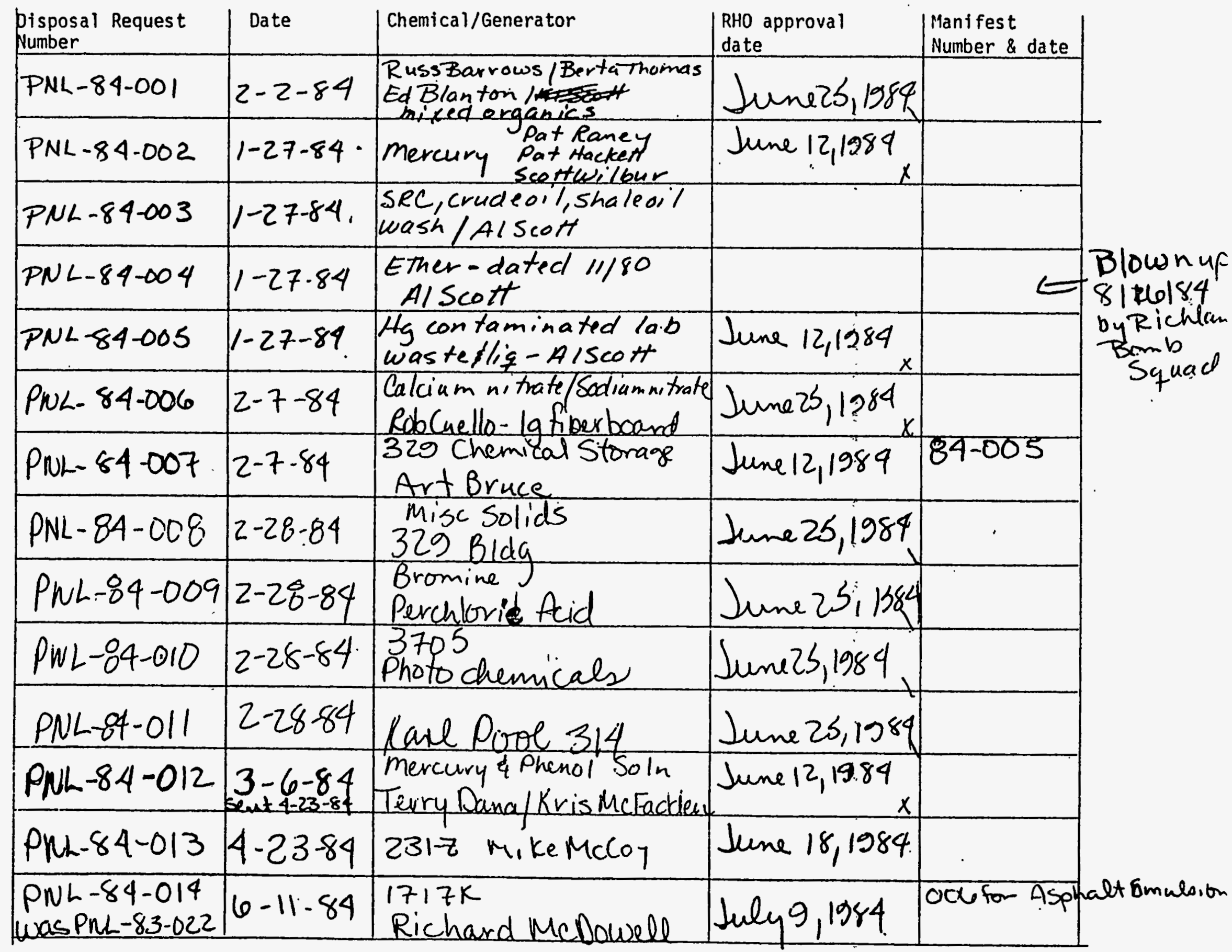


Date October 12, 1984

From

J. M. Hobbs Pliw for $6-16^{31}$

DISPOSAL OF PERONIOE-FORMING CHEMICALS

Rockwell is organizing a site-wide ether and peroxide-forming chemical disposal. This is a one-time event to clean out storage of old ethers and peroxide-forming "chemicals:

The worst of the peroxide-forming compounds are ethers, acetals, dienes, amides, and vinyl momomers. Some of the chemicals react with air to produce explosive peroxides even without concentration. Some common peroxide-forming chemicals are listed below.

\section{Common Peroxide-Forming Chemicals \\ Diethyl ether (ethyl ether) \\ Diisopropyl ether \\ ? $\left\{\begin{array}{l}\text { Cyclohexene } \\ \text { Cyclooctene }\end{array}\right.$ \\ Decalin \\ p-dioxane \\ Tetrahydrofuran \\ Tetralin \\ Vinyl acetone}

Perchloric acid and picric acid solutions may also be included for disposal.

Please identify peroxide-forming chemicals that need to be disposed and their location on the attached form and return to me no later $\because$ than October 19.: My address is 3762 31dgi300 Freai? V..

If you have any questions, contact me on 376-1631.

/slis

RECEIVED

OCT $16 \quad 1984$

E. R. JU8 Y 
PEROXID-FORMING CHEMICAL DISF ISAL REQUEST

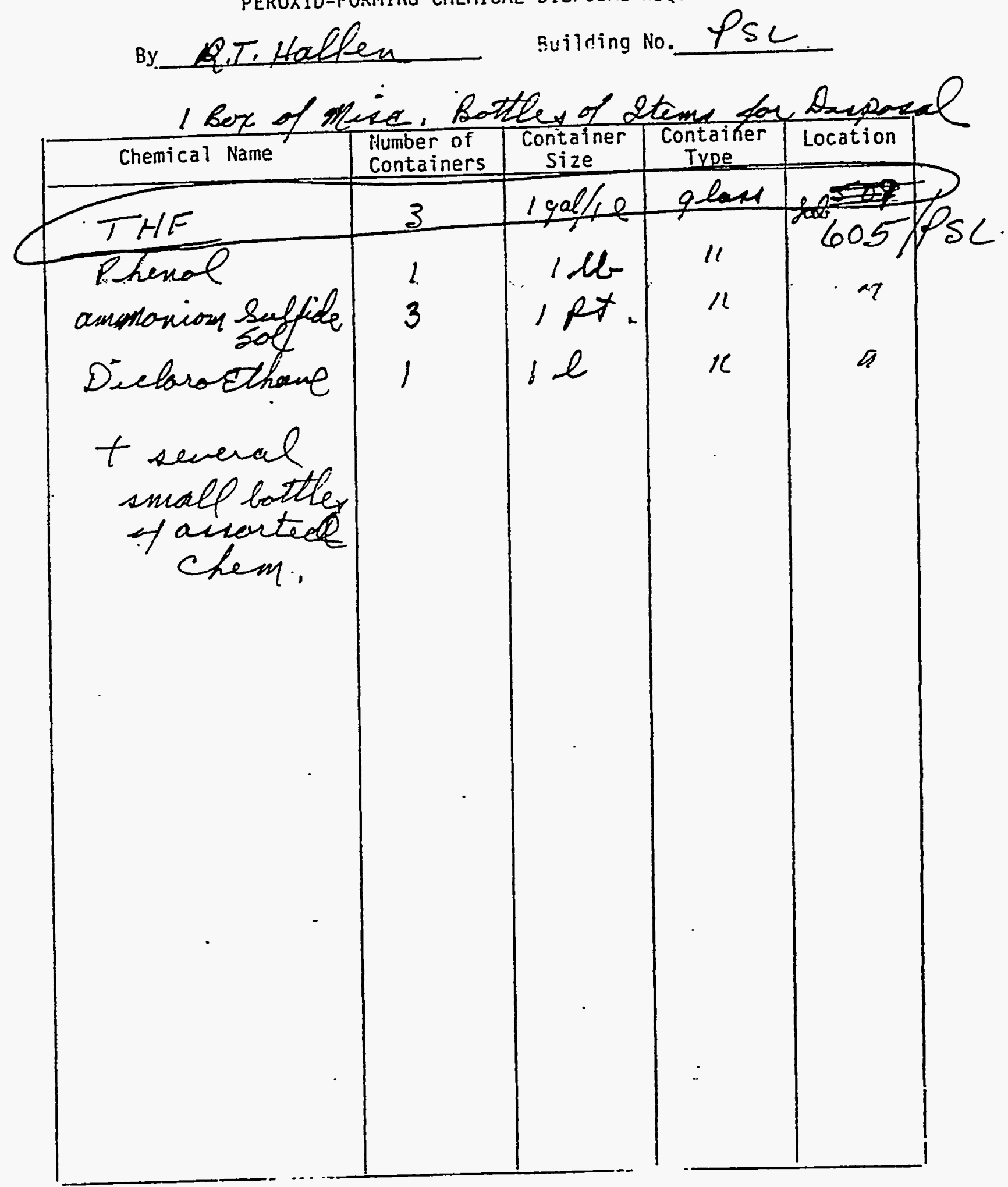

RETLPI: TO J. H. HOBBS - 3752;300/PHIL 


\section{5atielle}

Pacific Northwest Laboralories

Dale October 19, 1984

To Distribution

From Ernie Job Emiegel

Subiect Peroxide Forming Chemicals Disposal
Bill-do you detris

Project Number ix

Internal Distribution

WJ Apley

MC Bampton

TD Chikalla.

TJ Doherty

WA Glass

CR Hann

GJ Posakony

PM Potter

RA Stokes

$B E$ Vaughan

File/LB

The attached memo with a form for listing subject chemical's "for disposaz. asks for an unrealistic response date. Please prepare the list anyway, as quickly as possible, for EDL, PSL, CEL, MDL, MRC, RTL, 2400 Stevens and 1000 .

Return the completed form to Ernie Job in ESB. We will compile the lists and send the information to Jeanne Hobbs.

ERJ;ds

Attachment

RECEIYED

OCT 191994

T.D. CHIKA!LA 
Date October 12, 1984

JT Denovan

To Building Managers

M Romsos; RHO

JMH File/LB

From J. M. Hobbs flew for

subject DISPOSAL OF PEROXIDE-FORMING CHEMICALS

Rockwell is organizing a site-wide ether and peroxide-forming chemical disposal. This is a one-time event to clean out storage of old ethers and peroxide-forming chemicals.

The worst of the peroxide-forming compounds are ethers, acetals, dienes, amides, and vinyl momomers. Some of the chemicals react with air to produce explosive peroxides even without concentration. Some common peroxide-forming chemicals are listed below.

Common Peroxide-Forming Chemicals

Diethyl ether (ethyl ether)

Diisopropyl ether

Cyclohexene

Cyclooctene

Decalin<smiles>C=CC=CC</smiles>

p-dioxan

Tetrahydrofuran

Tetralin

Vinyl acetone

Perchloric acid and picric acid solutions may also be included for disposal.

Please identify peroxide-forming chemicals that need to be disposed and their location on the attached form and return to me no later than October 19. My address is $3762 \mathrm{Bldg} / 300$ Area/PNL.

If you have any questions, contact me on 376-1631.

/siw

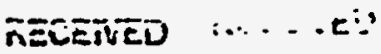

OCT 191984 ! "y४"

R\&NS 
PEROXID-FORHING CHEMICAL DISPOSAL REQUEST

By Freed Burton Building No.LSL-II

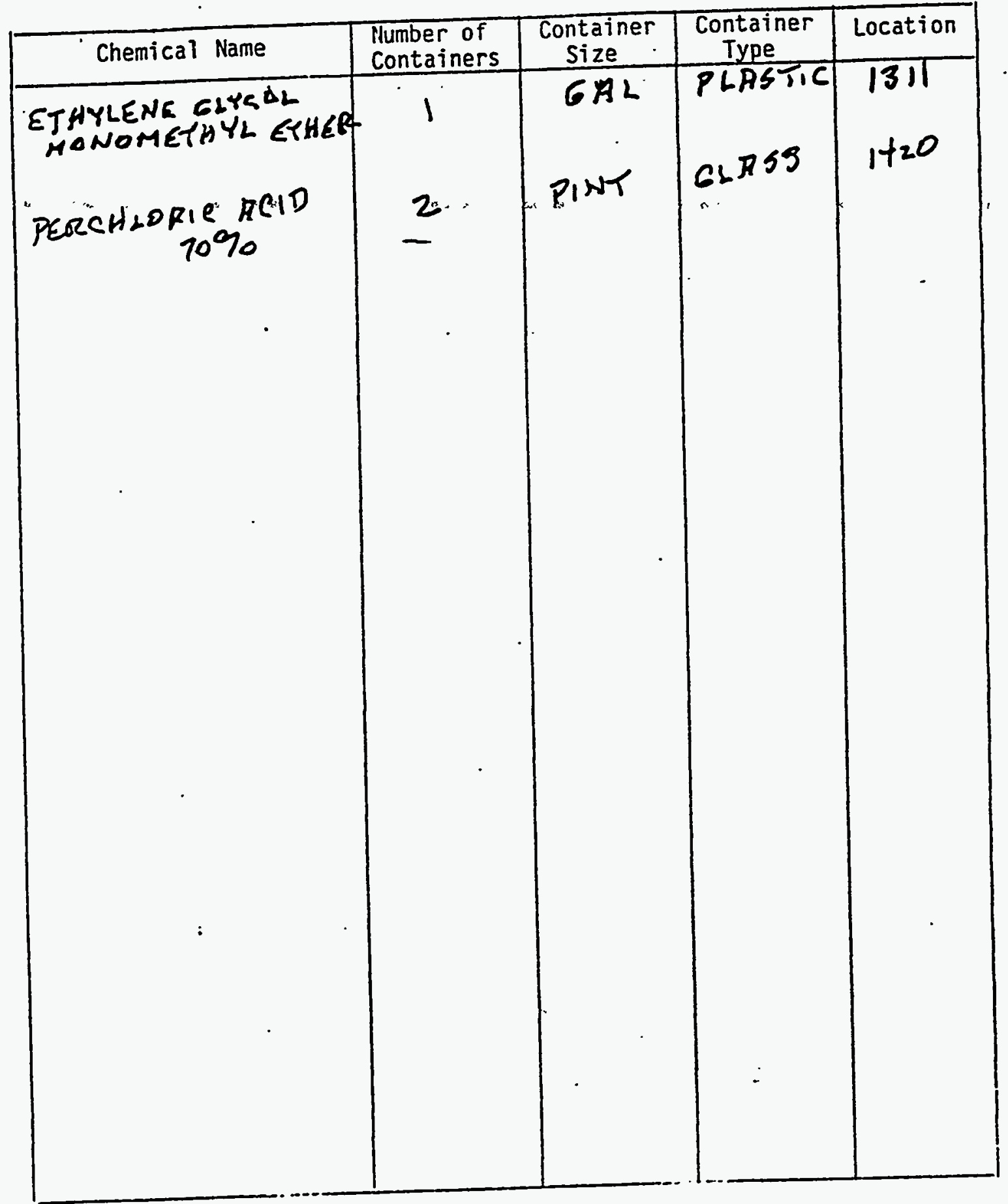

RETURN TO J. M. HOBBS - 3762/300/PNL 


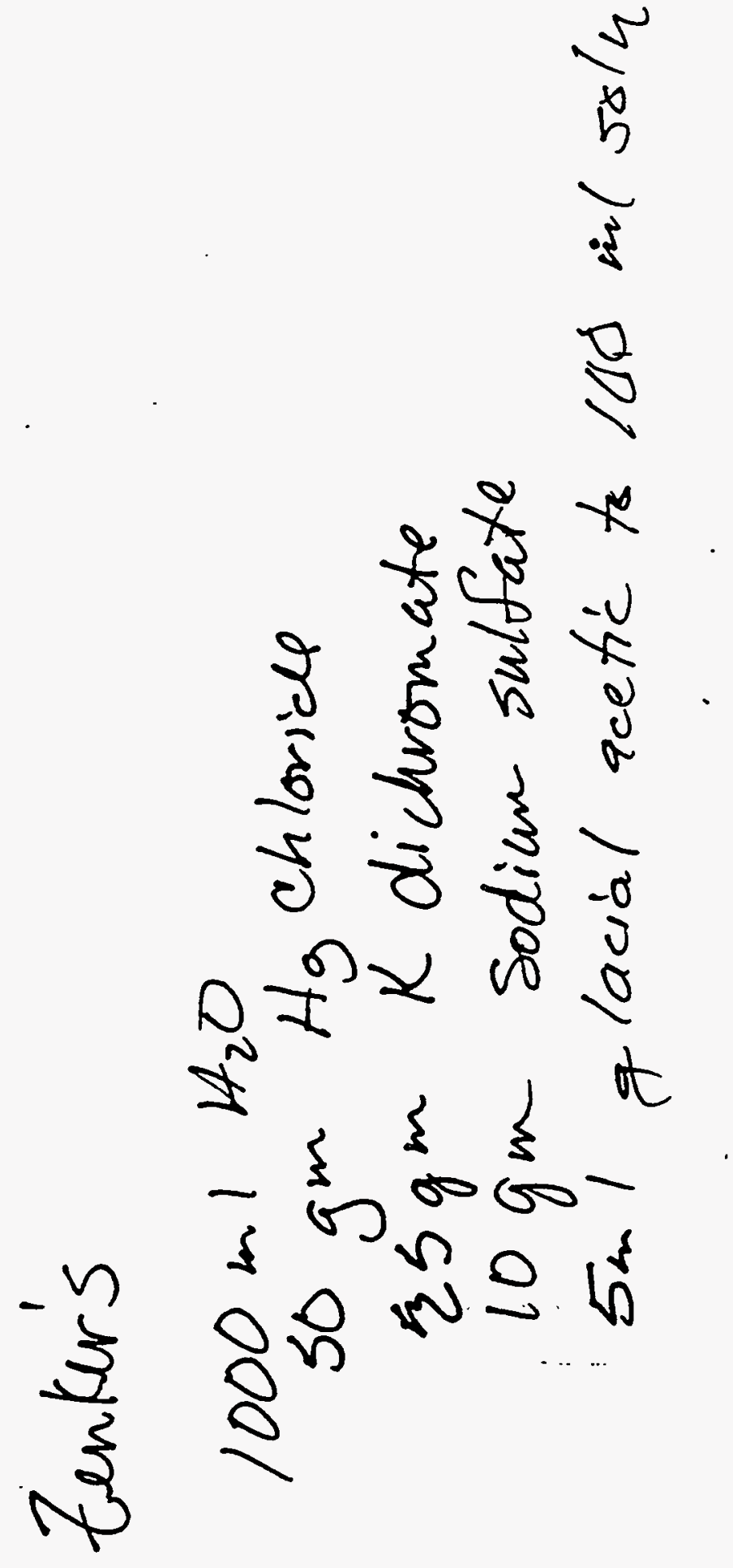


م

Paciiic Norihwest Lahor.ıloric:

DAc April 5, 1985

To PNL Ruilding Managers

from Jeene M. Hobos Zeene

Subject PEROXIDE-FORIMING CHEMICAL DISPOSAL
+. -

RECEIVED

APR 111985

R \& NS

Project Number

Internol Distrib:::inn

FG Burton

JA Piatt.

DJ Sominer JMH File/LB

Rockwell is organizing special disposal $\stackrel{\circ}{\circ}$ for peroxide-forming and unstable chemicals. Please contact your building occupants to determine if they have the following cheñitals for dissposal: " "perchloric acid, picric acid, ethyl ether; and tetrahydrofuran.

I need a list of the chemicals by April 18. The list should include the chemical name, quantity, building, room number, contact person, and phone number. Please list the chemical again even if I have been called abolit it pieviousiy. $\ddot{i}: \because \cdot$

If youl have questions, contact me on 376-163i. $/ s i v$

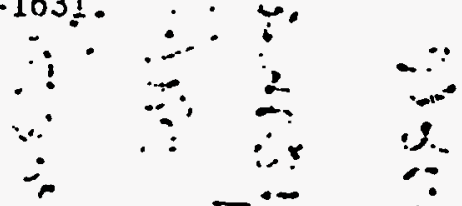

$2 \times 1.5$ pound Perchloric Acid 7.0\%a-LS安-II -1420

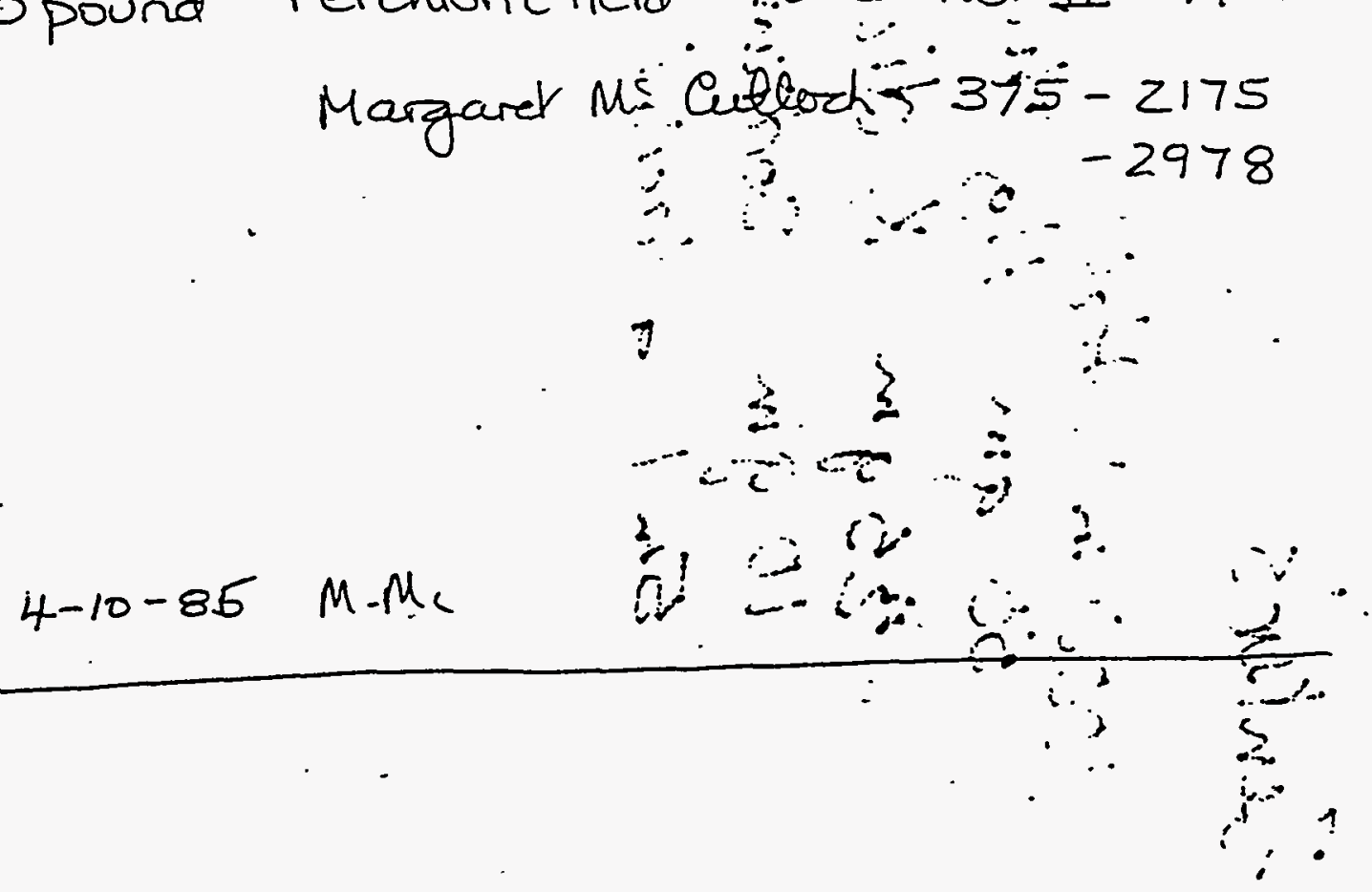


\%

Pacific Northwest Laboratories

Date

April 12, 1985

To

From

Subject Chemical Disposal
RECEIVED

APR $\perp 51985$

R \& NS
Project Number

Internal Distribution

SK Campbell

JS Fruchter

FO Gladfelder

CI Nelson

File

IB

Ref: Hobbs to PNL Building Managers, April 5, 1985

The Precipitation Chemistry Network uses Rooms 1415, 1419, and 1514 of Sigma $V$. All of these laboratory rooms have been searched for the items mentioned in the referenced memo, and none were found.

Since your last visit, we have accumulated 3 gallons of phenol in water waste $(126 \mathrm{gram} / \mathrm{gal})$. This is located in Room 1415 of Sigma $V$.

JR.

84.1900.001 (8/84) 
Add to Blow up list 2

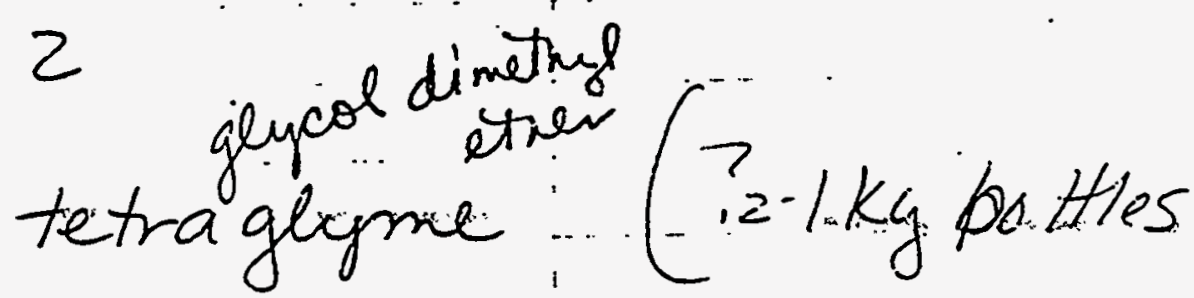

$\because$ Rpt benzene wiN-Bütul Lithium

Check on disposal request for CS Abernathy Flab cleanout
Al scoff last fall

Carbon. Disulfide ?

Dimity sulfoxide 
RECEDED

केष Baftelle

Pacific Northivest Laboratories

Date April 9, 1985

To Distribution

From

Subject Peroxide-Forming Chemical Disposal
Project Number PM Potter

Internal Distribution

GR\&E Section Mars.

EL Kelley

File/ lb

Ref: Hero, JM Hobbs to Building Manager, dated April 5, 1985, subject as above. (copy attached)

Please review and take necessary actions to satisfy requirements of the attached memo. As noted in the memo dene has requested a response no later than April 18. Please direct your response (if any) to her with copy to me.

Thanks in advance tor your prompt attention to this request.

FOG:Cla

$11 / 18 / 85$

Gene,

Bone

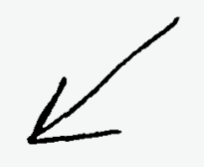




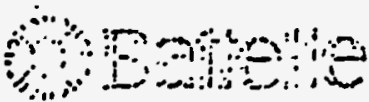

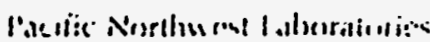

12::4: Apri7 5, 1985

To PNL Building Managers

rrom jeene H. Hobbs Jeene

Suhjoct PEROXIDE-FORHING CHEMICAL DISPOSAL

Rockwell is organizing special disposal for peroxide-forming and unstable chemicals. Please wcontact your building occupants to determine if they have the following chemicals for disposal: perchloric acid, picric acid, ethyl ether, and tetrahydrofuran.

I need a list of the chemicals by April 18. The list should include the chenical name, quantity, building, room number, contact person, and phone number. Please list the chemical again even if I have been called about it previously.

If you have questions, contact me on 376-1631.

/s Tw 
$940000-14110-301$

DONT SAY IT -.. Write It!

rofene Lob bs

Ref. Chemical Disposal

celt does not look ike of have any peroxide = forming chemical to be disposed of at this Ene.

There is a box $\sim 2$ cubic ft. of commented solid chemicals at 320 Cl that need to be disposed of. The contact is bol stein or Bol Ridley on 6.3605 .

"TO MAKE LIFE LAST, PUT SAFETY FIRST" 
RECENT:

APR 151985

Date April 12, 1985

To Jeene Hobbs

From Debbie Skiaffencen Geosciences R\&E

subject Your memo on "Peroxide-Forming Chemical Disposal"

I have the following items in sigma: 5:

ethyl ether -1-can (opened) - Rm 1411 - under hood

-1- 1 gal bottle (unopened) - back dock - Solvent cabinet \#1

THF -2-1 gal bottles (opened) - Rm 1510 - under hood -6- I gal bottles (unopened) - Back dock - Solvent cabinet \#1

(Key to the solvent cabinet is in Rm 1411 - desk drawer) Thanks!

$\mathrm{DSS} / \mathrm{mgS}$
Internal Distribution

SK Campbe 11

JS Fruchter

FO Gladfelder

CL NeTson

File

LB 
Prujerl intuni,er

menes

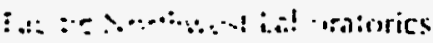

RECEIVED

APR 101985

r:? April 5, 1985

$R$ \& NS

$\therefore \quad$ PHiL Building lianagers

F... Jeanne M. Hobbs Dene

S:ijea PEROXIDE-FORHING CHEMICAL DISPOSAL

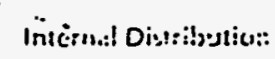

FG Burton

JA Plat

DJ Somite

JML File/LB

Rocki:ell is organizing special disposal for peroxide-forming and unstable chemicals. Please contact" your building occupants to determine if they have the following chemicals for disposal: perchloric acid, picric acid, ethyl ether, and tetrahydrofuran.

I need a list of the chemicals by April 18. The list should include the chemical name, quantity, building, room number, contact person, and phone number. Please list the cheinical again even if I have bes: ea: led brut it previously.

If you have questions, contact me on 376-1631.

$15]::$

gene,

Moue - 324 Bldg. or

$3=: 3 \div 6+\div \div=$ 


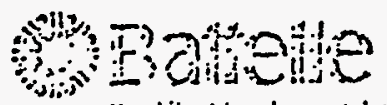

P'acioic Nonrlinwest t.aboratorins

Dare Apri1 5, 1985

To PNL Ruilding Managers

Froin Jeene H. Hobbs Peene

SUbject PEROXIDE-FORMING CHEMICAL DISPOSAL
FG Burton

JA Piatt

DJ Sommer

JMH File/LB

Rockwell is organizing special disposal for peroxide-forming and unstable: ehemieals. please contact your building occupants to determine if they have the following chemicals for disposal: perchloric acid, picric acid, ethyl ether, and tetrahydrofuran.

I need a list of the chemicals by April 18. The list should include the chemical name, quantity, building, room number, contact person, and phone number. Please list the chemical again even if i have been called about it previously.

If you have questions, contact me on $376-1631$.

$/ 57 w$ 


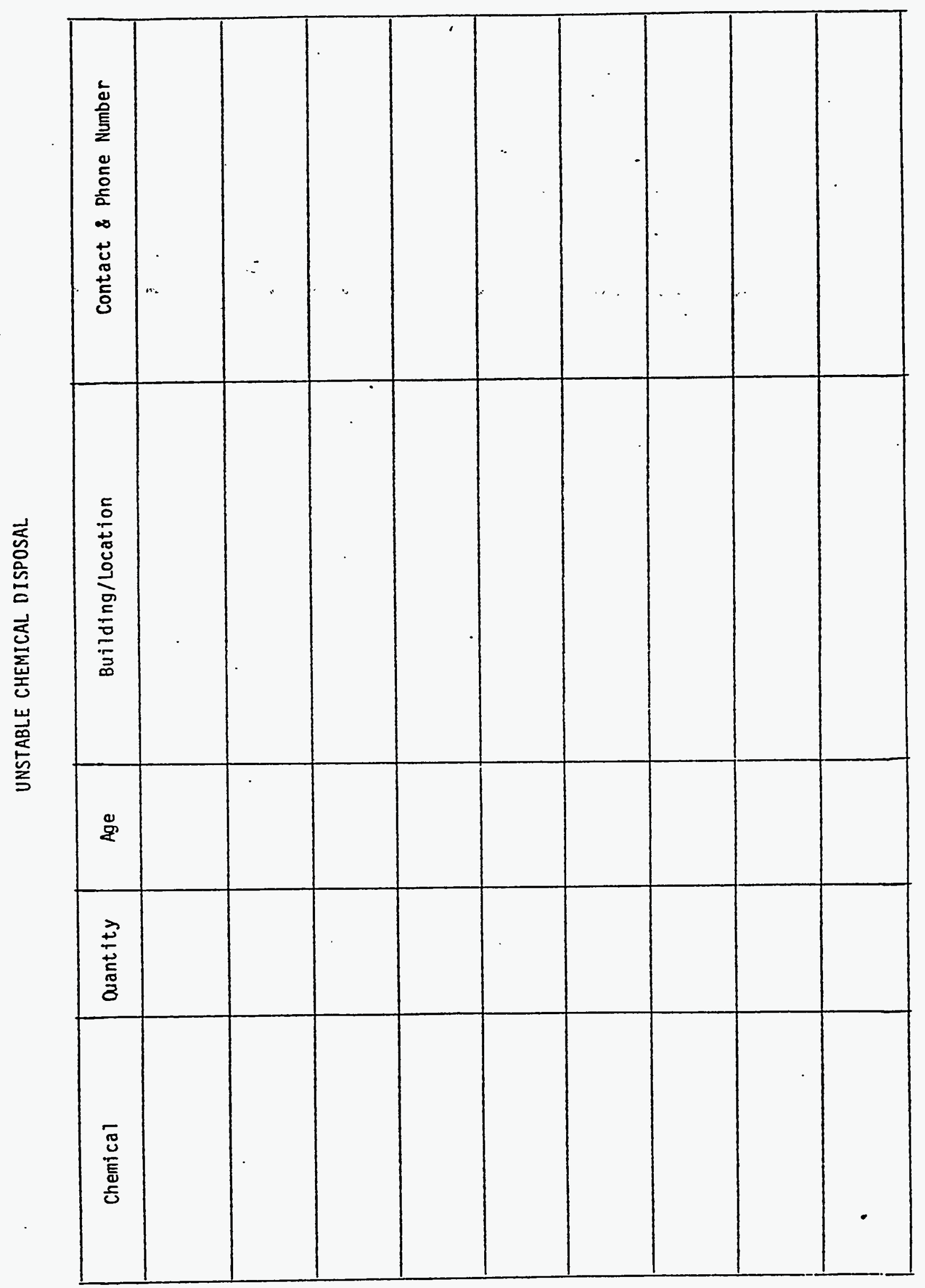




$$
\begin{aligned}
& \text { ruses i tho omos ond te } \\
& \text { mropls ard. tdt } 93 \\
& 27.2 u^{n} s \text { to } \varepsilon \text { हl ma le }
\end{aligned}
$$

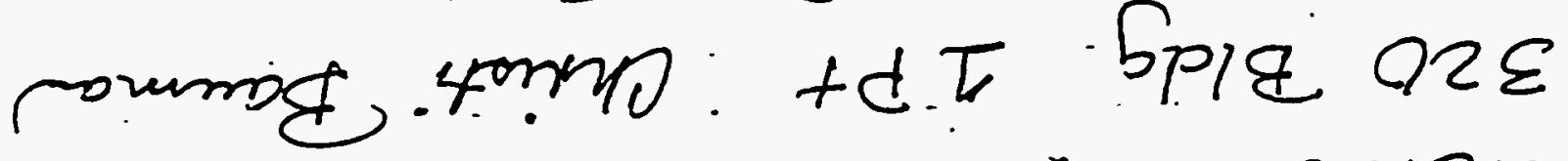

$$
\begin{aligned}
& \text { - pry piroppred } \\
& \mathrm{QS} / \mathrm{\theta} \\
& \text { sRroys pryosan mS }
\end{aligned}
$$

apoq ou moos pasedohs com ris grosmums asml ferues rerol hou oys

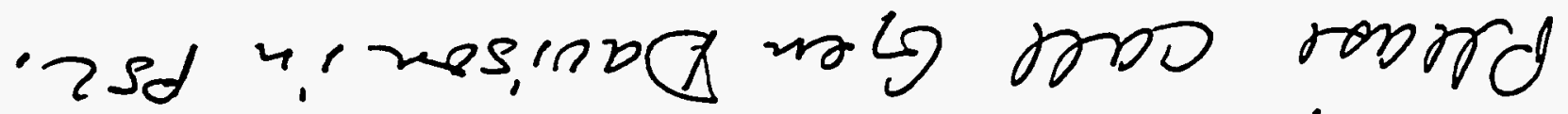
'f.' uf.'m promb roou' 'oproo QHA fI-rom I foum 5,2 r.

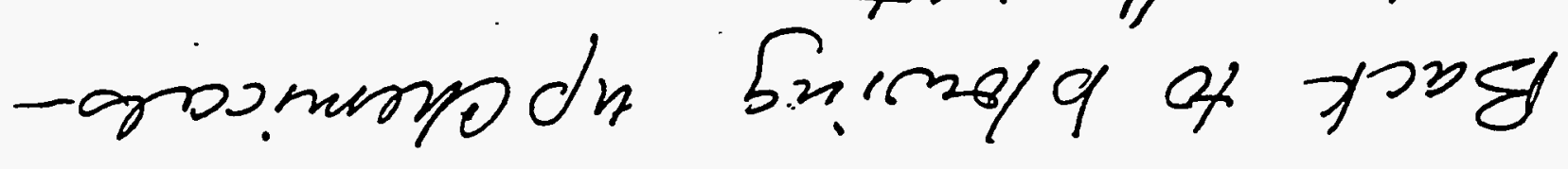
- th throby hous - nel 
Rockwoll Henford Oparations Eneroy Systums Group P.O. Box 800 Richland, WA 99352

October 2, 1984

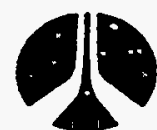

Rockwell International
RECEIYED

OCT $5 \quad 1984$

R \&. N.S

In reply, refer to Letter $\mathrm{R} 84-3497$

Ms. J. M. Hobbs

Laboratory Safety Department

Pacific Northwest Laboratory

Richtand, Washington 99352 . .

Dear Ms. Hobbs:

ORGANIC PEROXIDE DISPOSAL

This is to inform you that we are presently coordinating with the Richland Bomb Disposal Squad and other necessary elements to dispose of some potentialiy explosive organic peroxides which Rockwell Hanford Operations (Rockwell) has on site.

Mr. M. R. Romsos of my staff has informed me that you have a onepound container of ether which requires disposal. In order to save the Bomb Disposal Squad a trip, we would like to have your ether disposed of during our scheduled pickup.

Mr. Romsos and Mr. G. R. Cox of my staff both wish to express their concern over transporting this material other than by the means described in this correspondence. Since professional personnel and. equipment will be available, we strongly suggest they be utilized, and thereby reduce the potential risk to personnel.

Mr. Romsos will be in contact with you when the pickup times are defined. Information from you will be required concerning proper procedures for your facility. If you have any questions on this matter, feel free to contact Mr. Romsos on 373-3948.

Very truly yours,

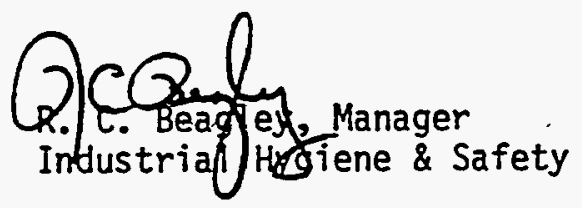

RDB/MRR: dlk 


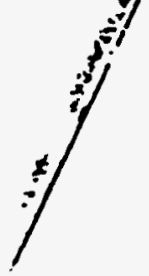

PEROXID-FORIING CHEMICAL: DISPOSAL REQUEST

ค. วง

By C.S Abernethey Building No. 331/Z300Anea

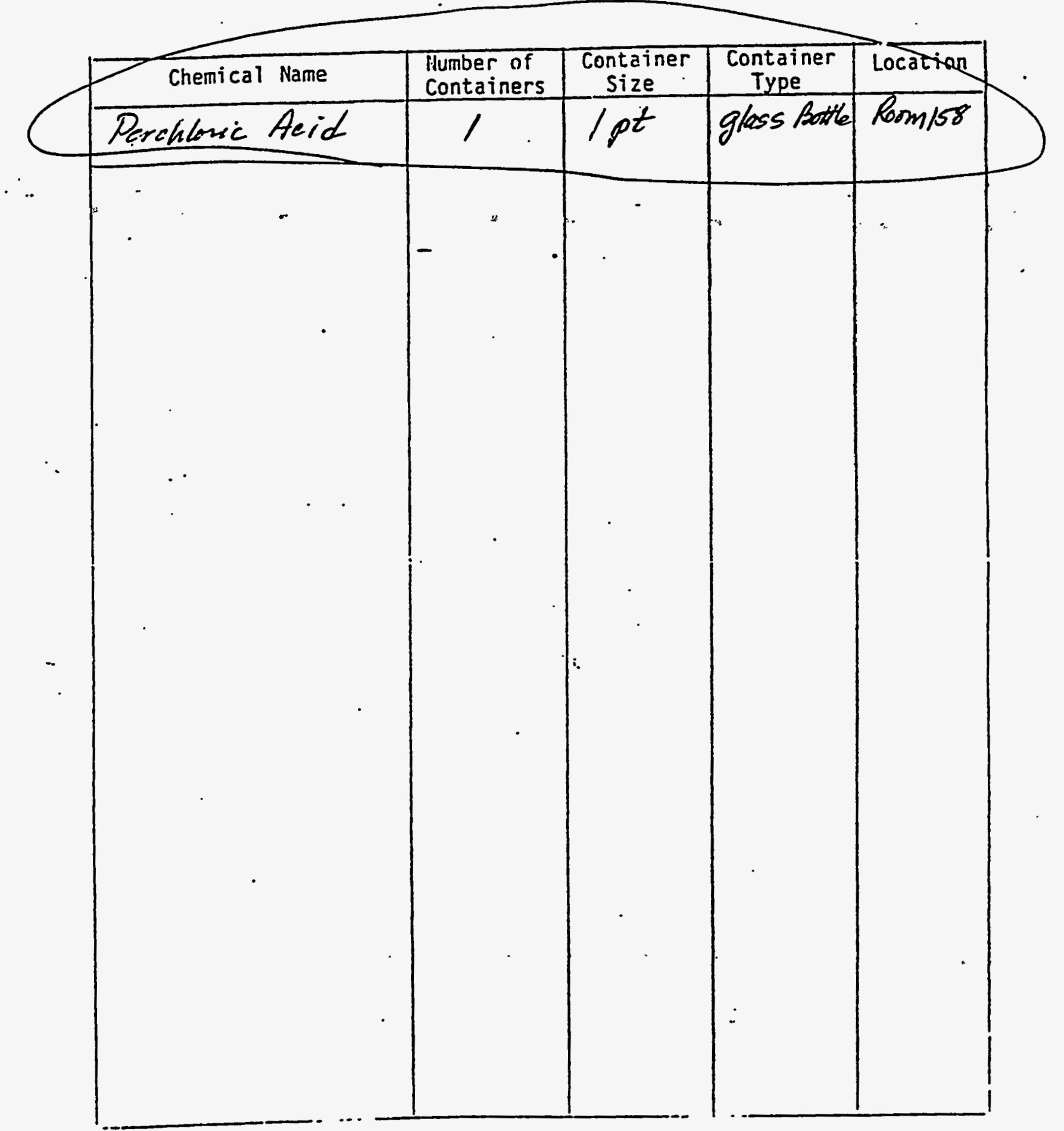

PETUP: TO J. H. HOBBS - 3752;300/PHL 


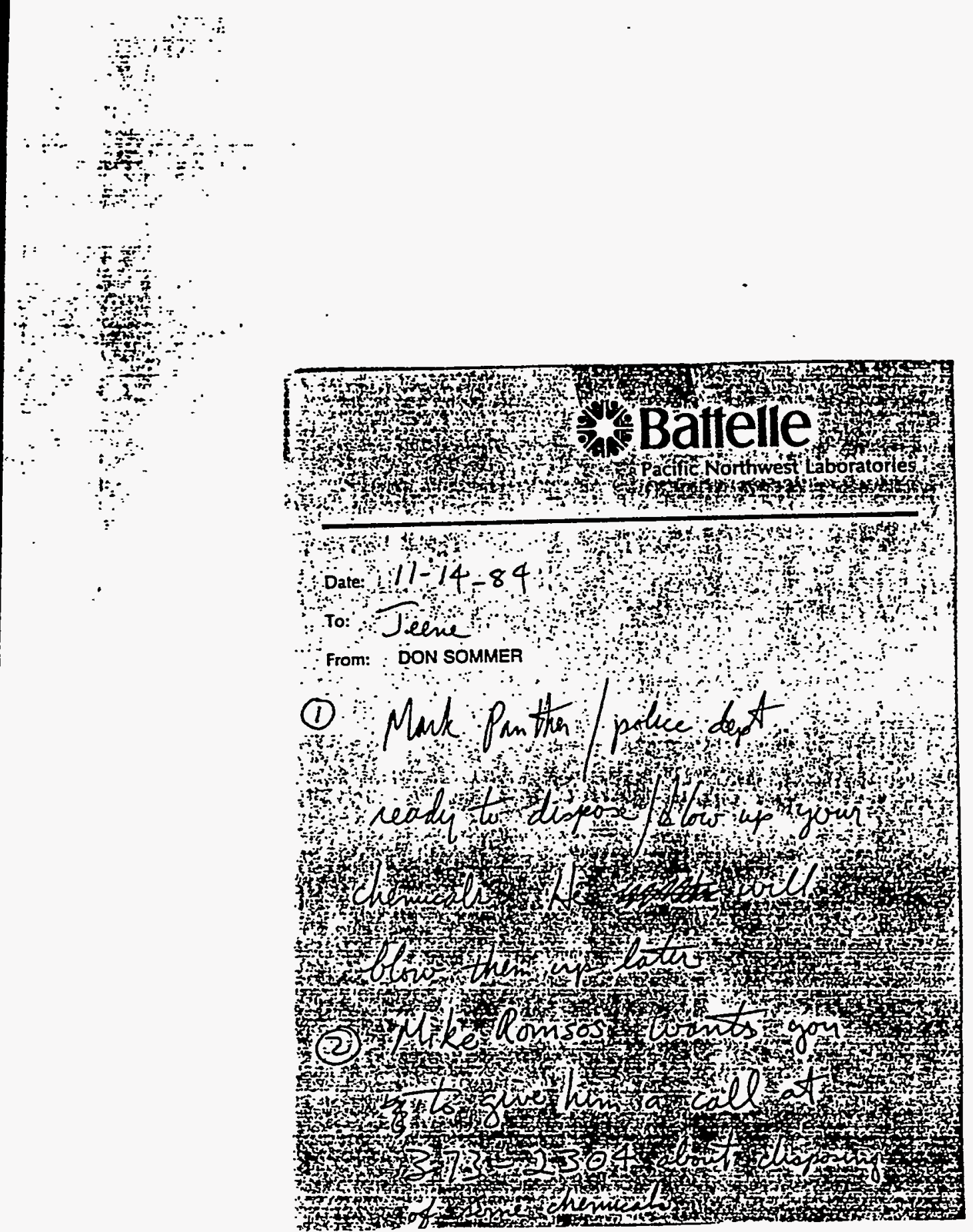




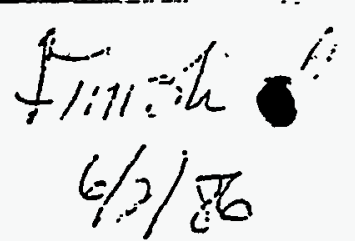

Rockwell Hanford Operations P.O. Box 800 Richland, WA 99352
HAY : ? 1950

Mr. D. L. Lundstrom

Pacific Northwest Laboratory.

Post Office Box 909

Richland, Hashington 99352

Dear Mr. Lundstrom:

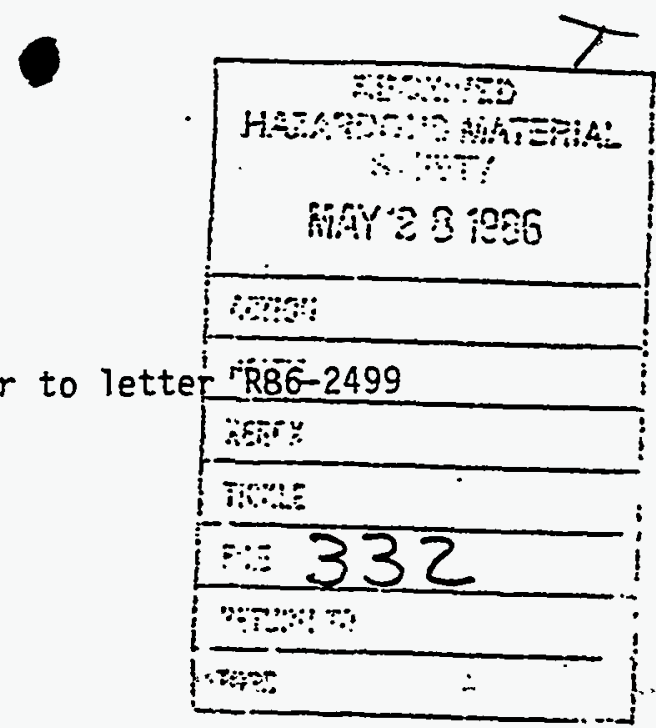

Fockwell

internaziona!

In renly, refer to letter r $86-2499$

CHEMICAL WASTE DISPOSAL ANALYSIS NO. PNL-22-83

Reference: Chemical kiaste Disposal Reouest $86-009$,

Apri1 2, 1986, D. L. Lundstrom to Solic Waste

Processino and Disposal Unit

The Rockwell Hanford Operations' Solid Waste Processing and Dispcsal

(SWP\&D) Unit has completed a waste disposal analysis for wastes

identified in the reference. Instructions for waste packaging and disposal are:

\section{General}

A11 hazardous wastes must be packaged and transporter according to Washington State Regulations WAC 173-303 and U. S. Department of Transportation (DOT) Reculations 49 CFR. Improperly Fack aced wastes will not be accepted by site disposal facility personnel and will be returned to you for corrections. These circumstances should, how' ever, be prevented by the pre-shipment inspection made hy our Unit personnel.

\section{Preparation for Shinment}

Wastes must be packaged, labeled and marked by the generator according to the instructions given in the attached disposal analysis. The instructions must comply with State of Hashington and DOT regulations. Please note that markings must be leoible, durable, and in a color which contrasts with the container. Labeis are availabie as store stock items.

\section{Inspection and Manifests}

When the waste has been properly packaged, SWP\&D Unit personnel will make a pre-shipment inspection to verify compliance with the packaoing instructions. Properly completed Uniform Hazardous Waste Manifest (s) will be delivered and initiated by the SWP\&.D Unit representative uDon satisfactory inspection. More than one manifest may be reauired, depending on shipping destinations and waste compatability. 
THE FOLLOY!ING ARE HAZARDOUS WASTES WHICH ARE UNSTABLE OR EXPLOSIVE. THESE WASTES SHOULD BE DISPOSED OF BY DETONATION. PLEASE CONTACT:
M. R. ROMSOS
$373-4032$

TO MAKE FUFTHER ARRANGEMENTS.
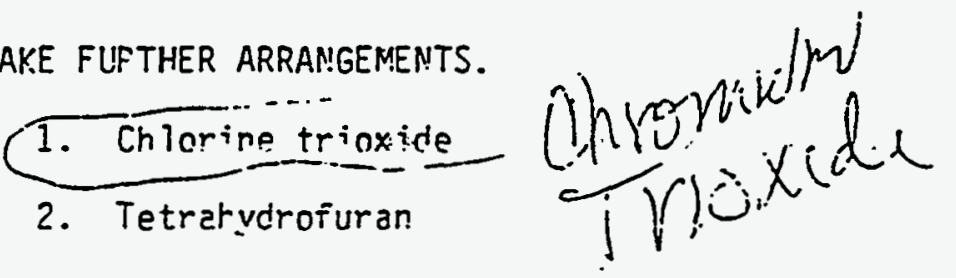

2. Tetratydrofuran $\operatorname{lnc} \mathrm{ml}$ 
DETONATION DISPOSN 3/19/86 RI

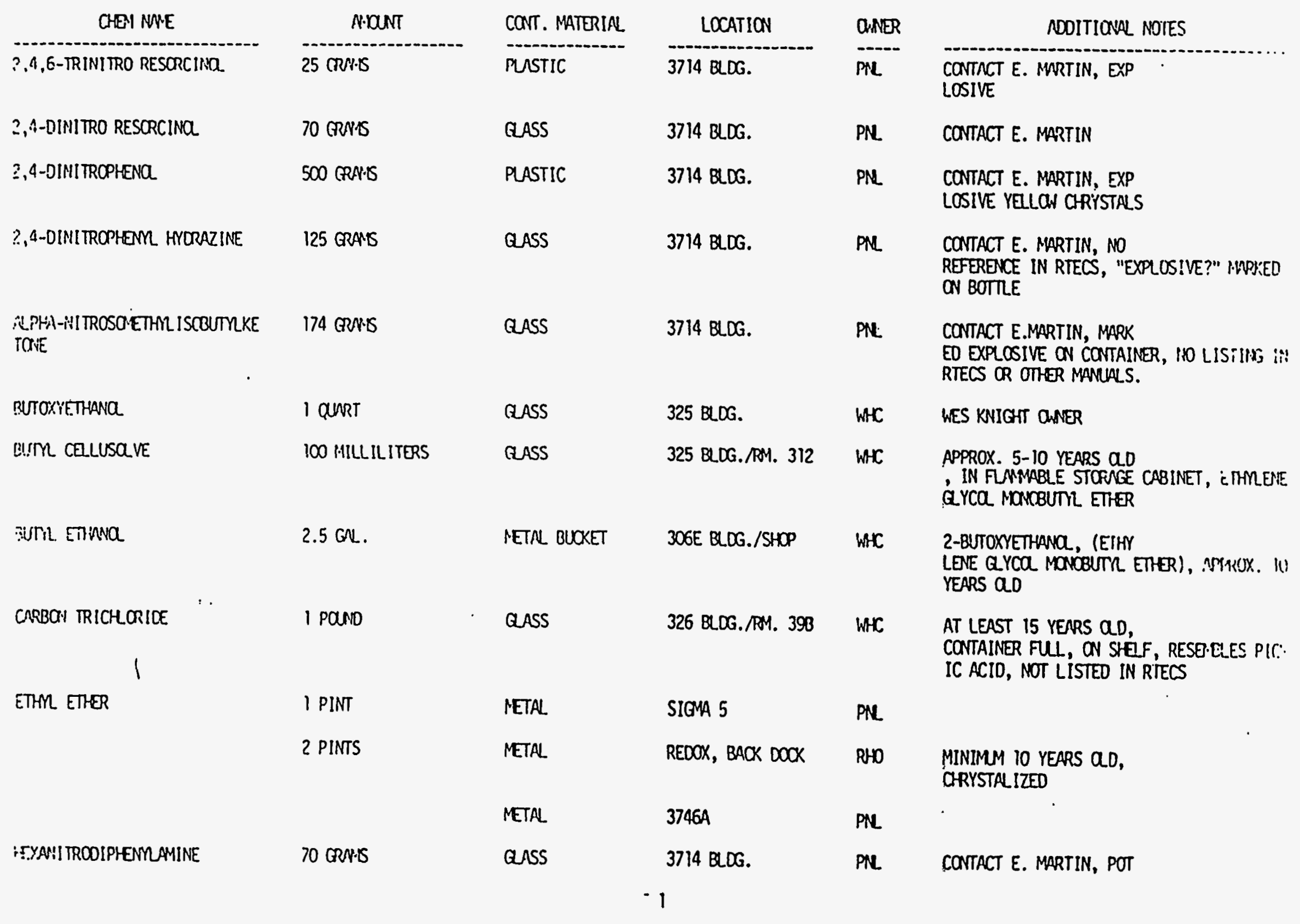


DETCRATIOA DISPOSN 3/19/26 RI

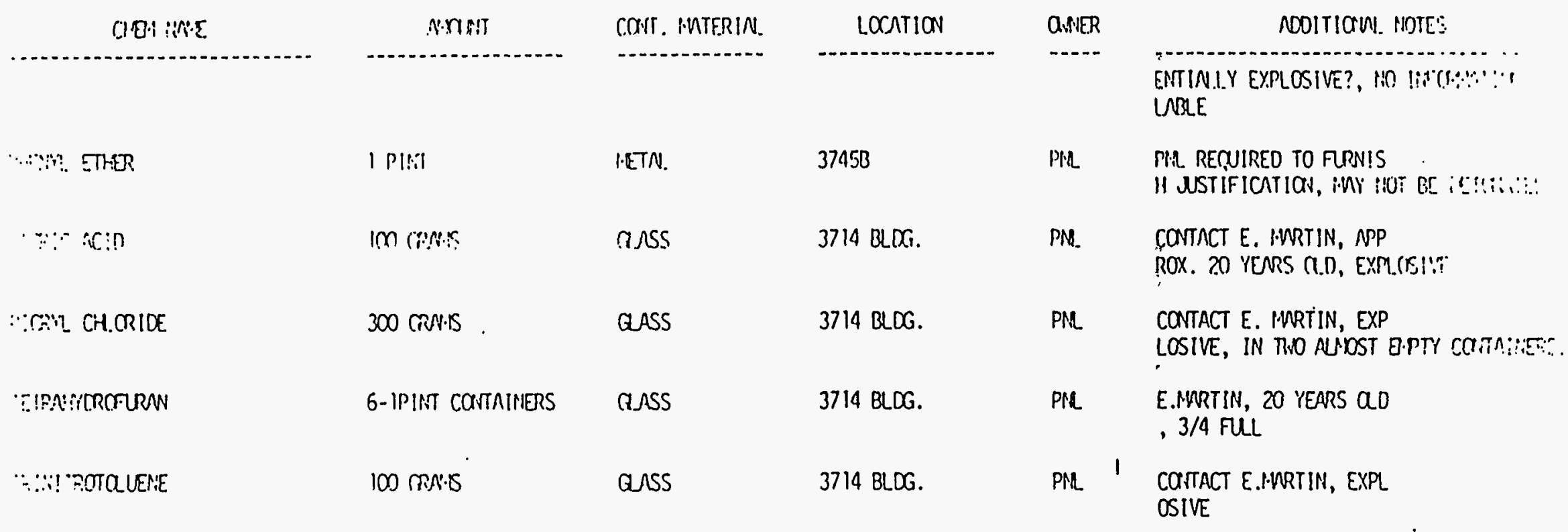


DISPOSAL ANALYSIS NO. PNL-22-129

- Each container must be legibly numbered on both the top and sides, using the manifest number and a unique container number, e.g., PNL-22-129-1.

- The weight of the outer container, if over 110 pounds, must be marked on the container.

- "Packạinos containing liquiơs" must be marked "This End Up", with an . arrow.

- In accordance with 49 CFR 172.301 and 172.304, a11 markings must be legible, durable, and in a color which contrasts with the container.

\section{NONHAZARDOUS WASTE}

The following items are not hazardous wastes as defined in WAC 173-303, and may be disposed of to a drain:

1. Phenylcyclohexane

2. Methylaniline

3. Dipheny 7 methare

4. Ethyl naphthaiene
$(86-010, \div 3)$

$(86-026, \# 3)$

$(86-010, \# 7)$

$(86-010, \# 8)$
$250 \mathrm{~m} 1$

$500 \mathrm{~g}$

0.96 iter

$12 @ 10 \mathrm{~g}$

THE FOLLOWING IS HAZARDOUS WASTE WHICH IS UNSTABLE OR EXPLOSIVE.

This waste should be disposed by detonation. Please contact M. R. Romsos on 373-4032 to make further arrangements.

1. Boron trifluoride etherate $\quad(86-026$, \#4) $1 \mathrm{~kg}$

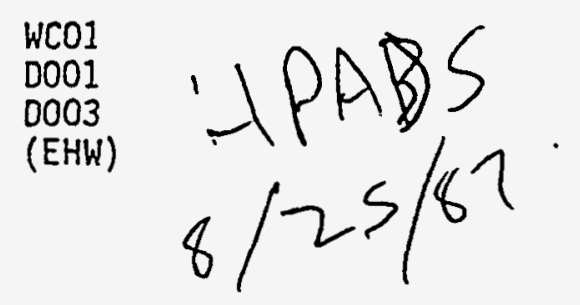




\author{
Rockwell Hanford Operations \\ P.O. Box 800
}

Richland. WA 99352 International
$\begin{aligned} & \text { Pacific Northwest Laboratory } \\ & \text { Richland, Washington } 99352\end{aligned}$

In reply, refer to letter
$\begin{aligned} & \text { Ms. J. M. Hobbs } \\ & \text { Pacific Northwest Laboratory } \\ & \text { Richland, Washington } 99352\end{aligned}$
Rockwell

International

Dear Ms. Hobbs:

CHEMICAL WASTE DISPOSAL ANALYSIS NO. PNL-22-176

Reference: Chemical Waste Disposal Request No. 86-040, June 5, 1986, J. M. Hobbs to Solid Waste Processing and Disposal Unit

The Rockwell Hanford Operations' Solid Waste Processino and Disposal (SWP\&D) Unit has completed a waste disposal analys is for wastes identified in the reference. Instructions for waste packaging and disposal are:

\section{General}

All hazardous wastes must be packaged and transported according to Washington State Regulations WAC 173-303 and Department of Transportation (DOT) Regulations 49 CFR. Improperly packaged wastes will not be accepted by site disposal facility personnel and wi 11 be returned to you for corrections. These circumstances should, however, be prevented by the pre-shipment inspection made by our Unit personnel.

\section{Preparation for Shipment}

Wastes must be packaged, labeled and marked by the generator according to the instructions given in the attached disposal analysis. The instructions must comply with state of Washington and DOT regulations. Please note that markings must be legible, durable, and in a color which contrasts with the container. Labels are available as store stock items.

\section{Inspection and Manifests}

When the waste has been properly packaged, SWP\&D Unit personnel will make a pre-shipment inspection to verify cormliance with the packaging instructions. Properly completed Uniform Hazardous Waste Manifest(s) will be delivered and initiated by the SWP\&D Unit representative upon satisfactory inspection. More than one manifest may be required, depending on shipping destinations and waste compatability. 
DISPOSAL ANALYSIS NO. PNL $-22-176$

NONHAZARDOUS WASTE

The following items are not hazardous wastes as defined in WAC 173.303, and may be sent to the Central Landfill Trash Trench for disposal. Please package these wastes so they are securely contained for transport and disposal.

NO MANIFEST IS REQUIRED FOR THESE ITEMS.

2. Ferric Oxide: $0.45 \mathrm{~kg}$

\section{UNSTABLE OR EXPLOSIVE WASTES}

The following are hazardous wastes which are unstable or explosive. These wastes should be disposed by detonation. P lease contact M. R. Romsos on 373-4032 to make further arrangements.

1. Carbon Disulfide: Five $500-\mathrm{m} 1$ bottles $(1.0 \mathrm{~kg})$

P022

0003

D001

(EHW) 


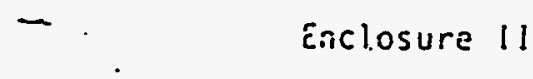

332 BUILD!I:G (OUTSIOE 300 AREA)

\begin{tabular}{|c|c|c|c|}
\hline Tetrahydrofuran & $100 \mathrm{ml}$ & glass & \\
\hline Tetrahydrofuran & $2.0 \mathrm{~kg}$ & glass & $2-1$ gallon \\
\hline Tétrahydro furan & $4 \mathrm{~kg}$ & giàss & \\
\hline $\begin{array}{l}\text { Triethylborane } \\
-1 \text { i solution in } \\
\text { hexane }\end{array}$ & $0.5 \mathrm{~kg}$ & $\begin{array}{l}\text { glass } \\
\text { in metal }\end{array}$ & \\
\hline Lithium hydride & $0.23 \mathrm{~kg}$ & glass & \\
\hline Acrolein & $0.4 \mathrm{~kg}$ & glass & \\
\hline Hydrazine & $1 \mathrm{~kg}$ & crate & \\
\hline Aluminum Chiloride & $0.45 \mathrm{~kg}$ & glass & \\
\hline $\begin{array}{l}\text { Unsymetrical } \\
\text { dimethyl } \\
\text { hydrazine }\end{array}$ & $0.01 \mathrm{~kg}$ & glass & \\
\hline $\begin{array}{l}\text { ר-nitrobenzoyl } \\
\text { nloride }\end{array}$ & $0.1 \mathrm{~kg}$ & glass & \\
\hline Sodium peroxide & $0.34 \mathrm{~kg}$ & metal & 3 containers \\
\hline $\begin{array}{l}\text { Benzene/butyl } \\
\text { lithium solution }\end{array}$ & $0.9 \mathrm{~kg}$ & glass & \\
\hline $\begin{array}{l}\text { Waste solvent } \\
\text { hexane/benzene/butyl lithium/ } \\
\text { tetrahydrofuran }\end{array}$ & $1 \mathrm{~kg}$ & glass & \\
\hline Chromium metal powder & 116 & glass & \\
\hline $\begin{array}{l}\text { Organic mixture: } \\
40 \% \text { toluene } \\
20 \% \text { ether } \\
5 \% \text { benzene } \\
5 \% \text { ethyl acetate } \\
30 \% \text { petrol eum ether }\end{array}$ & $4 \mathrm{~kg}$ & glass & \\
\hline $\begin{array}{l}\text { Organic mixture: } \\
50 \% \text { heptane } \\
50 \% \text { di-ethyl ether }\end{array}$ & $4 \mathrm{~kg}$ & glass & \\
\hline $\begin{array}{l}\text { Organic mixture: } \\
\because: \text { etllyl ether } \\
\because: \text { allyl magnesiun b:onitises }\end{array}$ & $1:$ g & gluss & \\
\hline
\end{tabular}




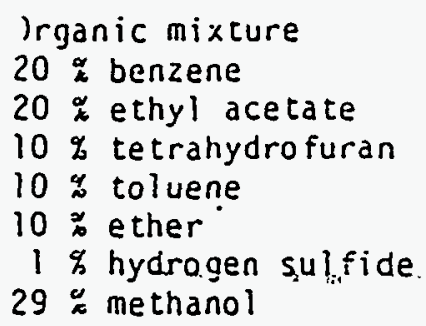

\begin{tabular}{lccl}
\hline & LSL-II BUILOIiG & (3000 AREA) & \\
Ethyl ether & 4 pints & metal & at least 9 years 0 ld \\
Ethyl ether & 6 gallons & glass & age unknown \\
Ethyi ether & 1 gallon & glass & $\begin{array}{l}\text { unopened, age } \\
\text { unknown }\end{array}$ \\
Picric acid & 5 grams & glass & re-wetted crystals \\
Picric acid & 1 lb & glass & dry crystals \\
\hline
\end{tabular}

SIGMA 5 BUILOIHG (3000 AREA)

shyl ether

I pint metal

unopened, age unknown

RTL BUILDING (3000 AREA)

Isopropyl ether

$\mathrm{l} \mathrm{kg}$ giass

at least $21 / 2 \mathrm{yrs}$ old, partially empty

325 BUILOING (.300 AREA :

$\begin{array}{llll}\text { Butoxyethanol } & 1 \text { quart } & \text { g!ass } & \text { age unknown. } \\ \text { Butyl Cellusolve } & 100 \mathrm{ml} & \text { glass } & 5-10 \text { years old }\end{array}$

326 BUILOIIIGS ( 300 AREA)

Carbon Trichioride

110 glass

15 years old. resembles picric acid

306E GUILOIHG (300) AREST;

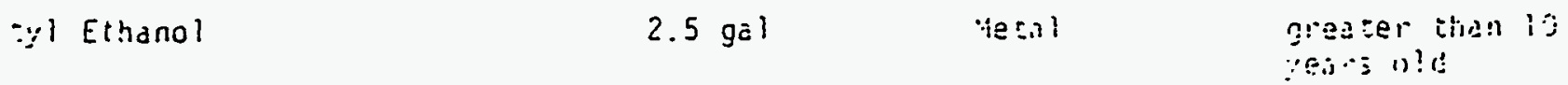


3714 BUILDING (IIISIDE 308 PROTECTEO AREA, IHSIDE 300 AREA)

\begin{tabular}{|c|c|c|c|}
\hline Picric Acid & 100 grams & glass & $\begin{array}{l}\text { approximately } \\
20 \text { years old, } \\
\text { explosive }\end{array}$ \\
\hline Picryl Chloride & 300 grams & glass & $\begin{array}{l}\text { explosive, in two } \\
\text { almost empty } \\
\text { containers }\end{array}$ \\
\hline Tetrahydro furan & pint cont. & glass & $\begin{array}{l}20 \text { years old, } \\
3 / 4 \text { full }\end{array}$ \\
\hline Trinitrotoluene & 100 grams & glass & explosive \\
\hline 4,6 - Trinitro Resorcinol & 25 grams & plastic & explosive \\
\hline 2,4 - Dinitro Resorcinol & 70 grams & giass & \\
\hline 2,4 - Dinitrophenol & 500 grams & plastic & $\begin{array}{l}\text { explosive, yellow } \\
\text { crystals }\end{array}$ \\
\hline 2,4 - dinitrophenyl hydrazine & 125 grams & glass & $\begin{array}{l}\text { explosive"? marked } \\
\text { on bottle }\end{array}$ \\
\hline ? pha-ni trosome thyl i sobutyl ke tone & $17 \dot{4}$ grams & glass & $\begin{array}{l}\text { marked explosive on } \\
\text { container }\end{array}$ \\
\hline Hexanitrodiphenylamine & 70 grams & glass & $\begin{array}{l}\text { potentially } \\
\text { explosive? }\end{array}$ \\
\hline
\end{tabular}

329 BUILDING (INSIDE 300 AREA)

Picric Acid $100 \mathrm{~g}$ glass old and dry

$3745 B$ BUILDING (INSIDE 300 AREA) ...

Phenyl ether 1 pint metal age unknown

3746A BUILDING (INSIDE 3CO AREA)

Ethyl Ether 2 pints metal age linknown 


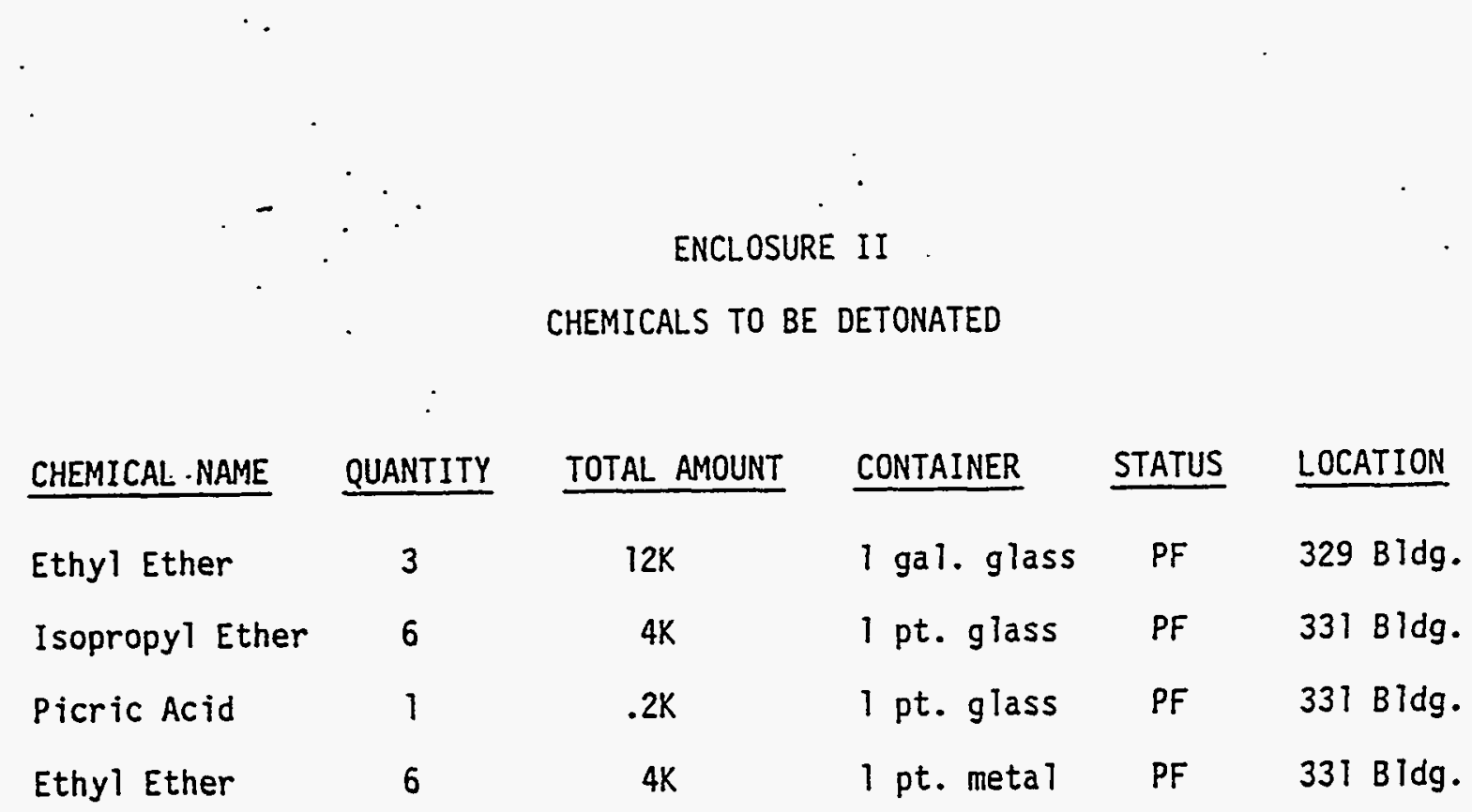




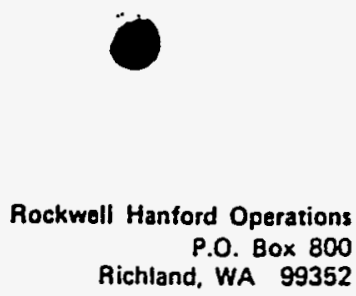

\begin{tabular}{|c|c|}
\hline \multirow{3}{*}{$\begin{array}{l}\text { Rockwell } \\
\text { International }\end{array}$} & 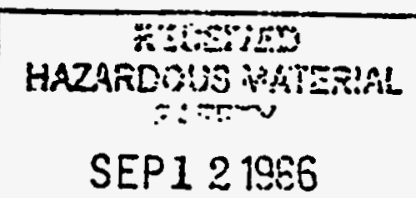 \\
\hline & ACTiôN \\
\hline & RDIJIE \\
\hline \multirow[t]{5}{*}{ In reply, refer to lett } & RER \\
\hline & Tactitie \\
\hline & rine \\
\hline & 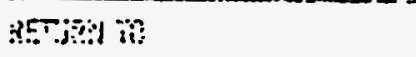 \\
\hline & : \\
\hline
\end{tabular}

Dear Mr. Lundstrom:

CHEMICAL WASTE DISPOSAL ANALYSIS NO. PNL-22-251

Reference: Chemical Waste Disposal Request 86-058, June 19, 1986, D. L. Lundstrom to Solid Waste Processing and Disposal Unit

The Rockwell Hanford Operations' Solid Waste Processing and Disposal (SWP\&D) Unit has completed a waste disposal analys is for wastes identified in the reference. Instructions for waste packaging and disposal are:

\section{General}

All hazardous wastes must be packaged and transported according to Washington State Regulations WAC 173-303 and Department of Transportation (DOT) Regulations 49 CFR. Improperly packaged wastes will not be accepted by site disposal facility personnel and will be returned to you for corrections. These circumstances should, however, be prevented by the pre-shipment inspection made by our Unit personnel.

\section{Preparation for Shipment}

Wastes must be packaged, labeled and marked by the generator according to the instructions given in the attached disposal analysis. The instructions must comply with State of Washington and DOT regulations. Please note that markings must be legible, durable, and in a color which contrasts with the container. Labels are available as store stock items.

\section{Inspection and Manifests}

When the waste has been properly packaged, SWP\&D Unit personnel will make a pre-shipment inspection to verify compliance with the packaging instructions. Properly completed Uniform Hazardous Waste Manifest(s) will be delivered and initiated by the SWP\&D Unit representative upon satisfactory inspection. More than one manifest may be required, depending on shipping destinations and waste compatability. 
DISPOSAL ANAL YSIS NO. PNL-22-251

THE FOLLOWING ITEMS ARE HAZARDOUS WASTES WHICH ARE UNSTABLE OR EXPLOSIVE. THESE WASTES SHOULD BE DISPOSED BY DETONATION. PLEASE CONTACT M. R. ROMSOS ON 373-4032 TO MAKE ARRANGEMENTS.

Item Number

(D001, F001, WTO2, WP01, WCO1, F003)
5
(WP01, F001,
F005, WT01,
WCO1)

\section{7}

(D001, WP01, F003, F005, WT02)

$$
\text { Waste }
$$

$35.0 \%$

$10.0 \%$

$17.0 \%$

$14.0 \%$

$1.0 \%$

$22.0 \%$

$1.0 \%$

$2.0 \%$

$30.0 \%$

$5.0 \%$

$3.0 \%$

$14.0 \%$

$4.0 \%$

$5.0 \%$

$4.0 \%$

$3.0 \%$

$1.0 \%$

$5.0 \%$

$3.0 \%$

$4.0 \%$

$1.0 \%$

$15.0 \%$

$1.0 \%$

25.0\% methanol

$25.0 \%$

$25.0 \%$

$10.0 \%$

$8.0 \%$

$3.0 \%$

$4.0 \%$

methanol

p-Dioxane

water

acetone

benzene

p-dioxane

toluene methanol

isooctane

toluene diethyl ether

tetrahydrofuran

carbon tetrachloride

$\mathrm{N}, \mathrm{N}$-d ime thy 1 formamide

$p-x y l o q u i n o n e$

hexane or heptane

ethyl acetate

tetrahydrofuran

carbon tetrachloride

methyl isobutenyl ketone

2-furaldehyde

2,4-dimethyl-3-dioxolane-2-

$\mathrm{N}, \mathrm{N}$-d ime thy lace tamide

chlorotoluene

decahydronaphthalenes

tetrahydronaphthalene

\section{tetrahydrofuran}

methyl phenyl ethanone

2-ethy 1-5-methy 1-2-dioxane

benzene propanoyl chloride

plus tetramethylbenzene
Quantity/Container/Amount

1

glass bottle

$3.0 \mathrm{~kg}$ 1-gal

1

glass bottle 1-ga ]
$3.0 \mathrm{~kg}$
1 glass $3.0 \mathrm{~kg}$ bottle 1-gal 
Item Number

11
(FOO3; FO05;
WT02, WPO1;
WCO1, DO01)

12

(D001, WP01, WT01, F005, F003, F001, WCO1)
Waste

45.0\% methanol

$0.5 \%$ acetone

$6.0 \% \quad C_{6}-C_{8}$ hydrocarbons

29.0\% tetrahydrofuran

$1.0 \%$ benzene

4.0\% 1-chloro-2-propanol

$13.0 \%$ toluene

$1.0 \%$ methyl phosphate

$0.5 \%$ 2-ethyl-5-methy $1-1,4-$ dioxane

$\begin{array}{rl}50.0 \% & \text { acetone } \\ 10.0 \% & \text { methanol } \\ 5.0 \% & \text { carbon tetrachloride } \\ 5.0 \% & \text { benzene } \\ 10.0 \% & \text { heptane } \\ 10.0 \% & \text { toluene } \\ 3.0 \% & \text { pyrridine borane } \\ 3.0 \% & \mathrm{~N}, \mathrm{~N}-\mathrm{dimethyl} \text { acetamide } \\ 2.0 \% & \text { methyl isobutenyl ketone } \\ 2.0 \% & \text { pentoxone }\end{array}$

Quantity/Container/Amount

1

glass $\quad 3.0 \mathrm{~kg}$ bottle

1-gal

$1 \quad \begin{aligned} & \text { glass } \\ & \text { bottle } \\ & 1-g a l\end{aligned}$




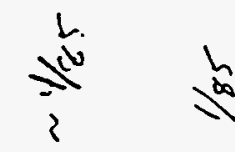

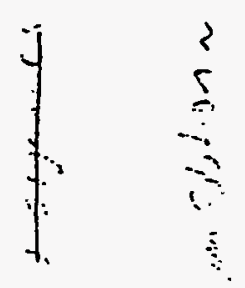

$\therefore \quad \therefore$

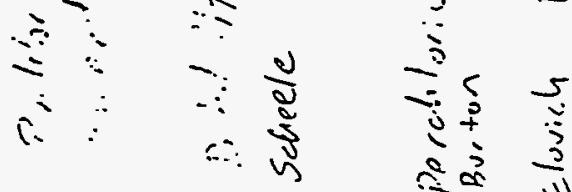

$v$

v

$\therefore$

$r$

ن

$\frac{1}{2} i^{\infty}$

2क $\frac{3}{11}$

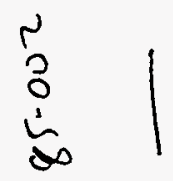




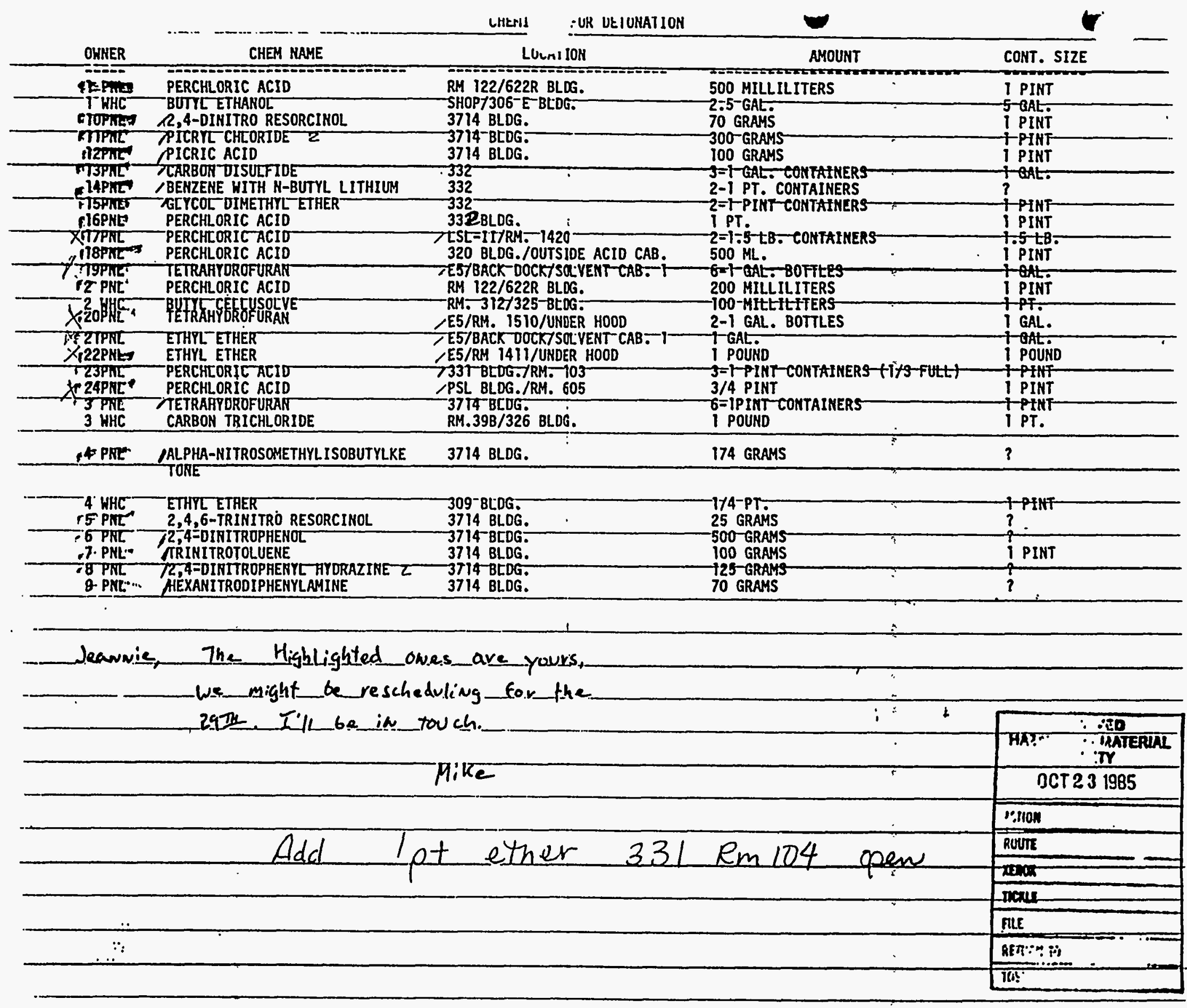




\section{วิ) Battelle}

Pacific Northwest Laboratories

Date October 24,1985

To Distribution

From

Subject

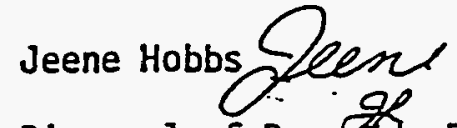

Disposal of Peroxide Forming Chemicals
Project Number

Internal Distribution

JH Choate

FO Gladfelder

SC Hawley

ER Job

SW Li

EC Martin

MJ Pueschner

GL Roberts

DS SKlarew

JMH/Fi.le/LB

Arrangements have finally been made to dispose of your potentially explosive chemicals. We will be collecting them with assistance from the City of Richland Bonb Squad.

The collection date is Wednesday, October 30, after regular business hours. I will come around either Tuesday or Wednesday to make sure that I can still find the chenicals.

If you have any questions, please call me on 376-1631.

$\mathrm{JMH}: \mathrm{j} 1$ 


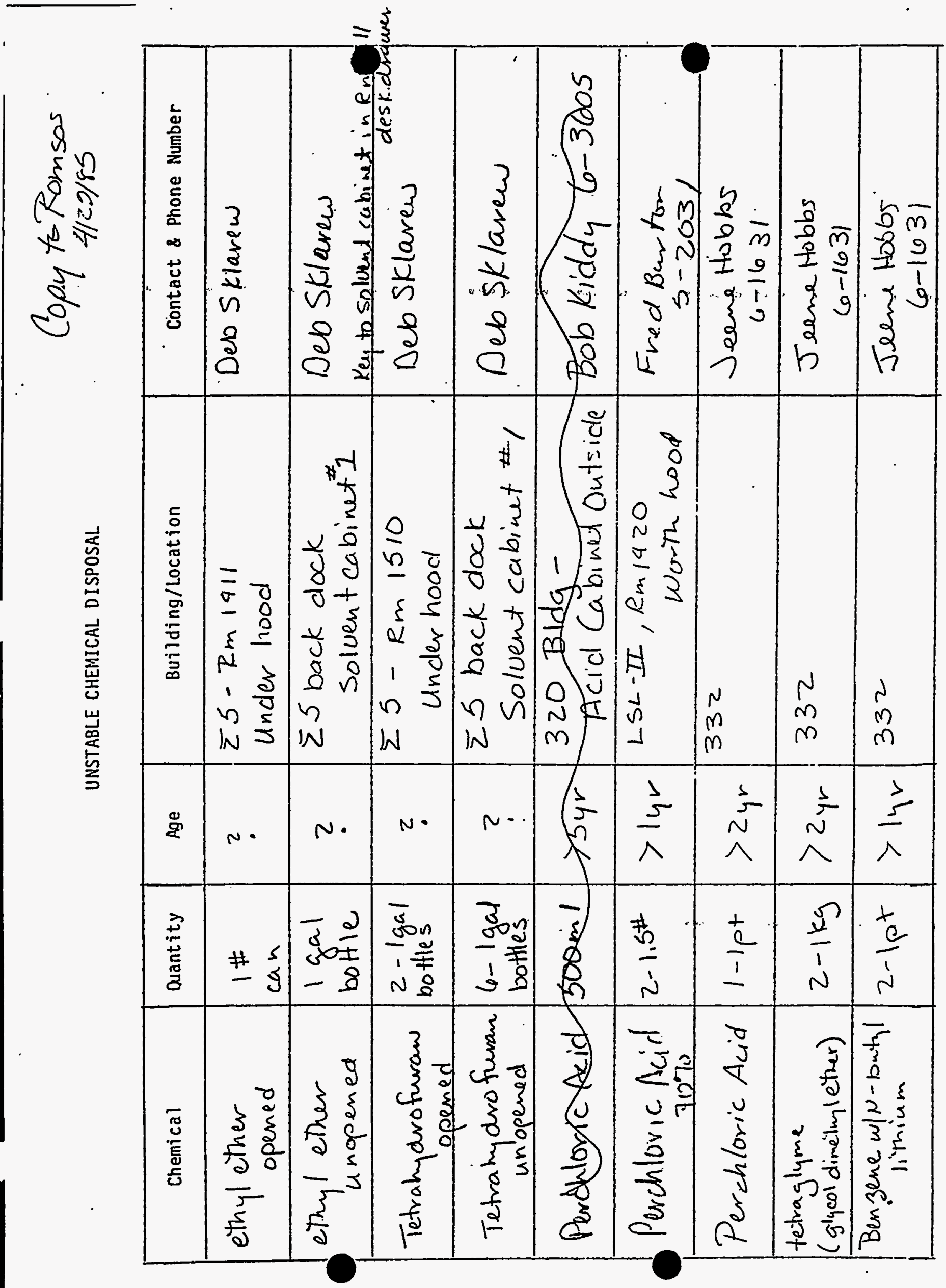


UNSTABLE CHEMICAL DISPOSAL

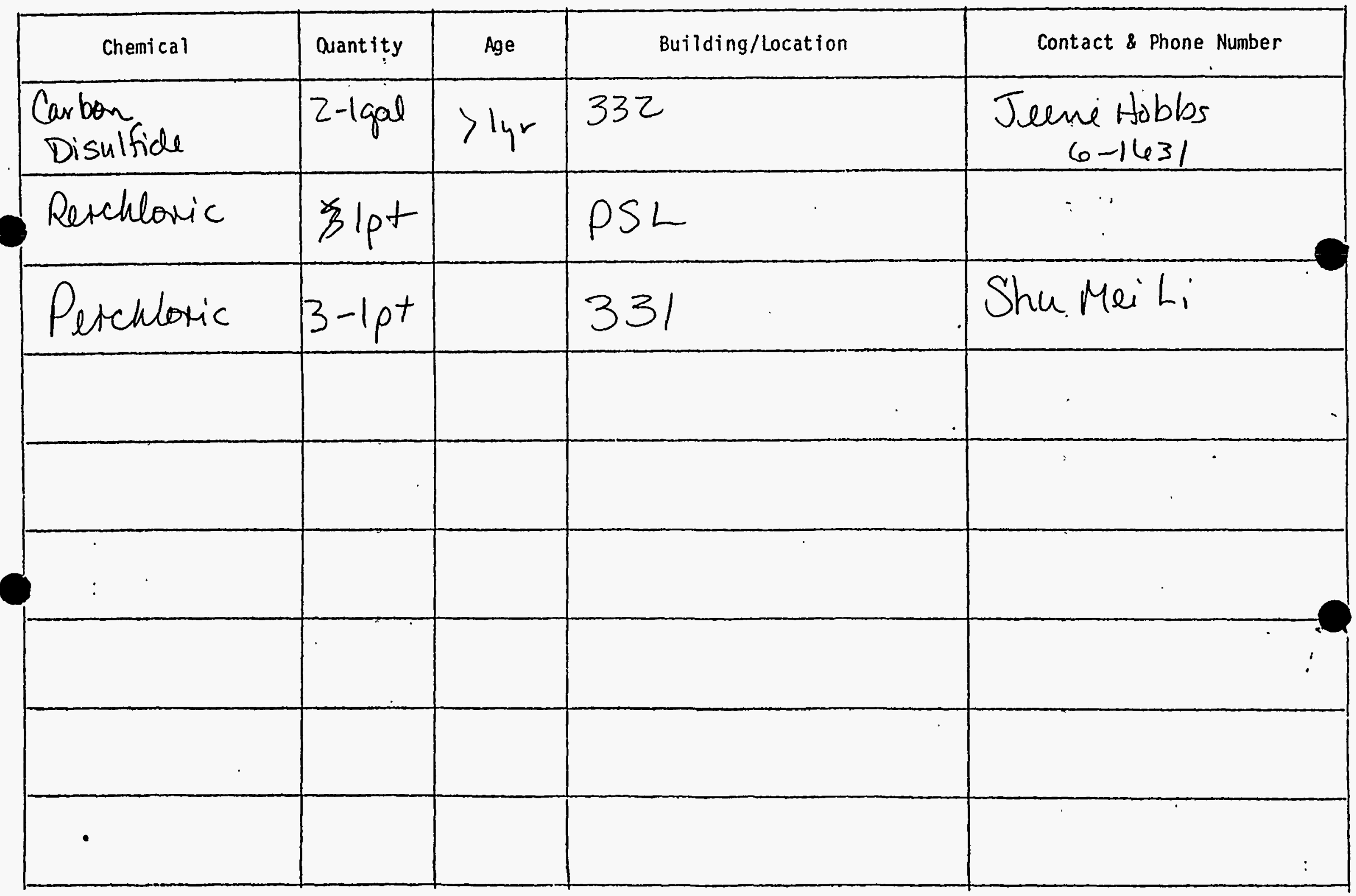


$340000-10110 \rightarrow 01$

DON'T SAY IT -.. Write It!

DATE $5 / 8 / 85$

ro Jeene Hobbs

FROM

$\frac{\text { Dick lee }(375-3830)}{2400 \text { Stevens }}$

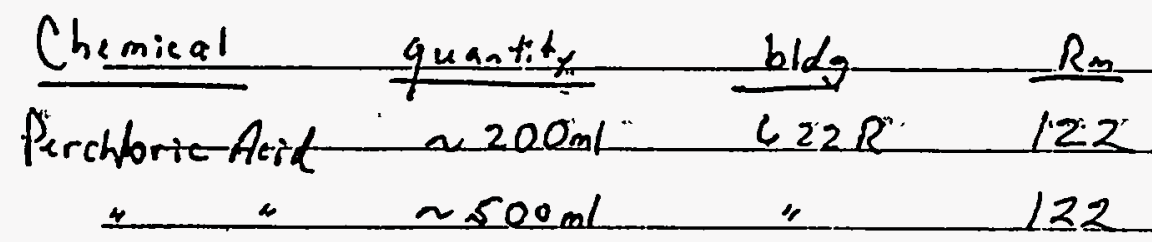

$\leftarrow$ unopened qlass

bul6.

Sorry for the late response to your mence Tye been out of town.

Dik Le 
Milici

1 HaVE (fir dispusal)
RECENED

$$
4 / 16 / 85
$$

APR 301985 .

$100 \mathrm{~g}$ - Picric Acid i. $>300^{\circ} \mathrm{C}$ pencumin

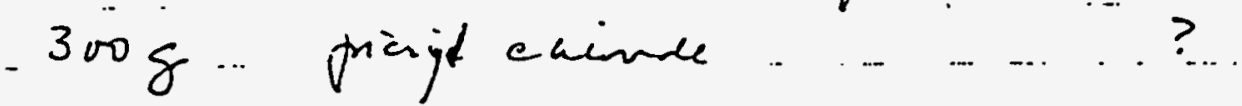
log 1.4 di nutro resorsivol ...... sting zental $70 \mathrm{~g}$. Zexa intro diphenglamine. To Explode

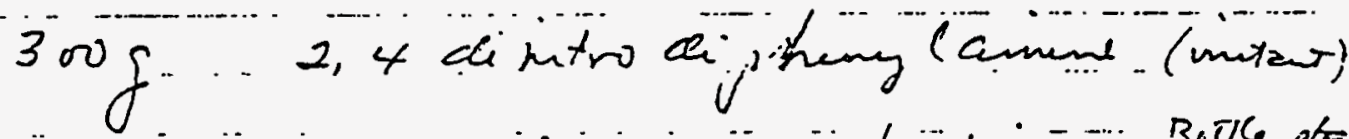

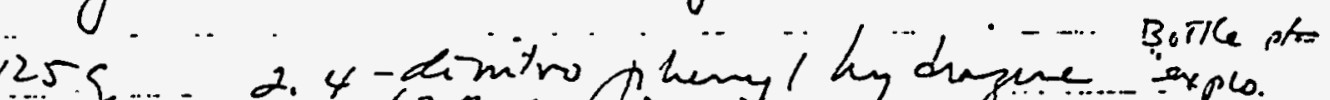

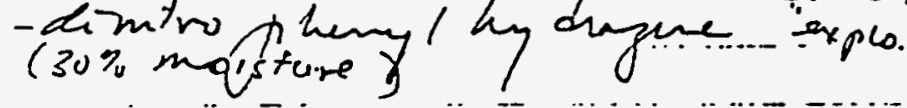

$\therefore$. oo $f$.... Trinito trenen

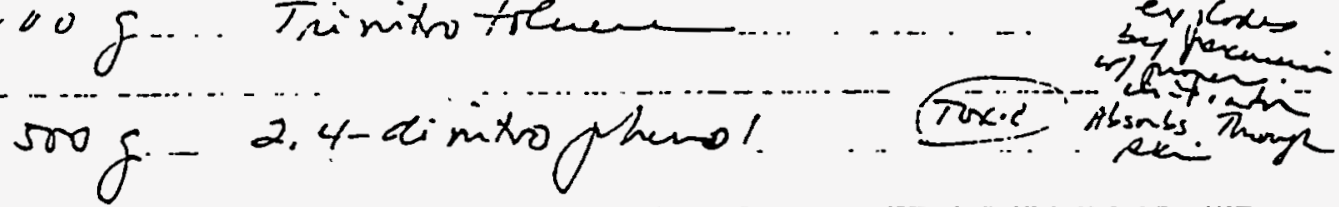
25 g. 2,4,6 - Trimitro resucines. reflogutes an

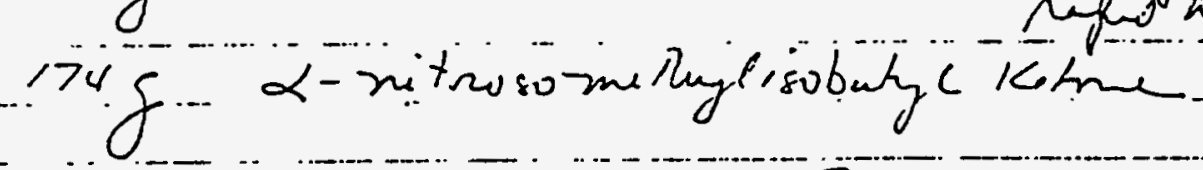
$37 \because 4$ is Ge unartic $6-3578$

1 cant get a pod y- Yene -

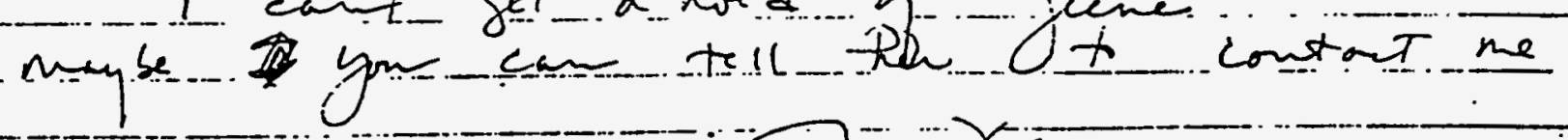

$-3$ 1.2215 
3714 BUILDING (INSIDE 308 PROTECTED AREA, INSIDE 300 AREA)

\begin{tabular}{|c|c|c|c|}
\hline Picric Acid & 100 grams & glass & $\begin{array}{l}\text { approximately } \\
20 \text { years old, explosive }\end{array}$ \\
\hline Picrył Chloride & 300 grams. & glass & $\begin{array}{l}\text { explosive, in two } \\
\text { almost empty containers }\end{array}$ \\
\hline Tetrahydrofuran & 6-1pint cont. & glass & $\begin{array}{l}20 \text { years old, } \\
3 / 4 \text { full }\end{array}$ \\
\hline Trinitrotoluene & 100 grams & glass & explosive \\
\hline 4,6-Trinitro Resorcinol & 25 grams & plastic & explosive \\
\hline 2,4-Dinitro Resorcinol & 70 grams & glass & \\
\hline 2,4-Dinitrophenol & 500 grams & plastic & $\begin{array}{l}\text { explosive } \\
\text { yellow crystals }\end{array}$ \\
\hline 2,4-dinitrophenyl hydrazine & 125 grams & glass & $\begin{array}{l}\text { explosive"? marked on } \\
\text { bottle }\end{array}$ \\
\hline Alpha-nitrosomethyl isobutylk & $\begin{array}{l}\text { tone } \\
174 \text { grams }\end{array}$ & glass & $\begin{array}{l}\text { marked explosive on } \\
\text { container }\end{array}$ \\
\hline Hexanitrodiphenylamine & 70 grams & glass & potentially explosive?, \\
\hline
\end{tabular}

329 BUILDING (INSIDE 300 AREA)

Picric Acid $20 \mathrm{~g}$ glass old and dry

Alumina \& Picric Acid ' $150 \mathrm{~g} \quad 1$ gal w water cover

$3745 B$ BUILDING (INSIDE 300 AREA)

Phenyl ether 1 pint glass age unknown

3746A BUILDING (INSIDE 300 AREA)

Ethyl Ether 2 pints metal age unknown 
332 Building (OUTSIDE 300 AREA)

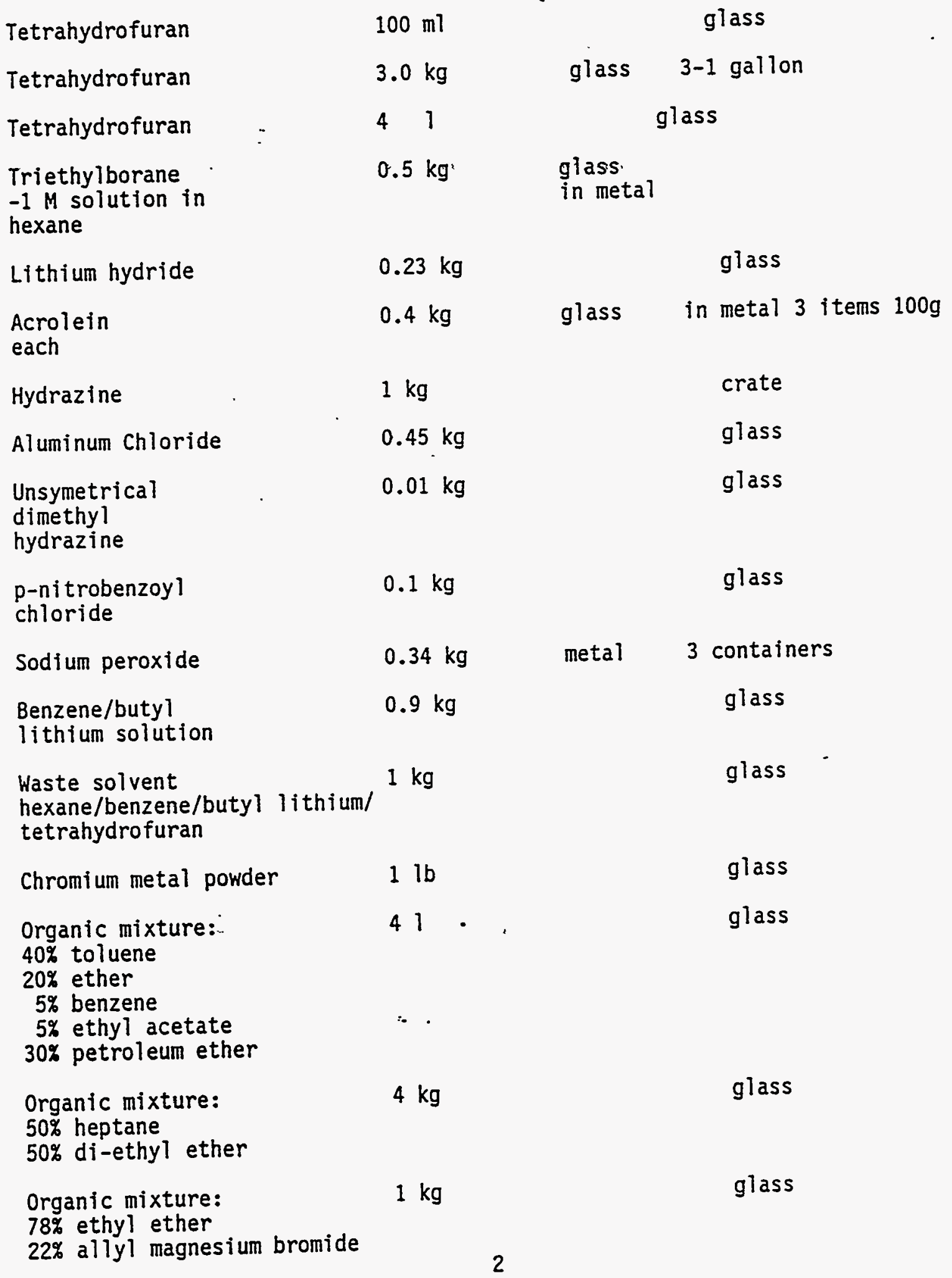




\section{Building (CONT)}

\begin{tabular}{|c|c|c|}
\hline Alumimium Chioride & $140 z$ & \\
\hline Hydrazine & $1 \mathrm{~kg}$ & crate \\
\hline $\begin{array}{l}\text { Organic mixture: } \\
20 \% \text { benzene } \\
20 \% \text { ethyl acetate } \\
10 \% \text { tetrahydrofuran } \\
10 \% \text { toluene } \\
10 \% \text { ether } \\
1 \% \text { hydrogen sulfide } \\
29 \% \text { methanol }\end{array}$ & $4 \mathrm{~kg}$ & glass \\
\hline $\begin{array}{l}\text { Organic Mixture: } \\
85 \% \text { Hexane } \\
5 \% \text { Ether } \\
10 \% \text { Ethylacetate }\end{array}$ & $1 \mathrm{gal}$ & glass \\
\hline $\begin{array}{l}\text { Organic Mixture: } \\
30 \% \mathrm{Et}_{2} \mathrm{O} \\
10 \% \mathrm{H}_{2} \mathrm{O} \\
10 \% \mathrm{MeOH} \\
40 \% \text { IPA } \\
10 \% \text { Pentane }\end{array}$ & $1 \mathrm{gal}$ & glass \\
\hline $\begin{array}{l}40 \% \text { Organic Mixture: } \\
25 \% \text { iso-octane } \\
20 \% \text { t-Butyl methyl ether } \\
10 \% \text { ether } \\
5 \% \text { Acetone }\end{array}$ & $1 \mathrm{gal}$ & 1 glass \\
\hline $\begin{array}{l}80 \% \text { Organic Mixture: } \\
5 \% \text { methylene chlorite } \\
5 \% \text { acetone } \\
5 \% \text { Benzene } \\
5 \% \text { acetonitrile } \\
5 \% \text { ether }\end{array}$ & $1 \mathrm{gal}$ & glass \\
\hline $\begin{array}{l}\text { Organic Mixture } \\
10 \% \text { Dichlormethone } \\
75 \% \text { Hexane } \\
5 \% \text { Ether } \\
10 \% \text { Ethyl Acetate }\end{array}$ & $1 \mathrm{gal}$ & glass \\
\hline
\end{tabular}


332 Building (contd)

Organic Mixture:

$\begin{array}{lcc}50 \% \text { Hexane } & & \\ 10 \% \text { Acetone } & 1 \mathrm{gal} & \text { glass } \\ 10 \% \text { Ether } & & \\ 20 \% \text { Benzene } & & \\ 10 \% \text { THF } & & \\ & & \\ \text { Carbon sulfide } & 5-1 \# & \text { glass } \\ \text { Boron trifluoride etherate } & 1 \# & \text { glass } \\ \text { Butyl lithium waste } & 11 & \end{array}$

\begin{tabular}{|c|c|c|c|}
\hline \multicolumn{4}{|c|}{ LSL - II BUILDING (3000 AREA $)$} \\
\hline Ethyl ether & 5 pints & metal & at least 9 yrs old \\
\hline Ethyl ether & 8 liters & glass & age unknown \\
\hline Ethyl ether & 1 gallon & glass & $\begin{array}{l}\text { unopened, } \\
\text { age unknown }\end{array}$ \\
\hline Picric acid & 5 grams & glass & re-wetted crystals \\
\hline Picric acid & $1 \mathrm{lb}$ & glass & dry crystall \\
\hline Picric acid & $1 \mathrm{lb}$ & glass & dry crystals \\
\hline \multicolumn{4}{|c|}{ SIGMA 5 BUILDING (3000 AREA) } \\
\hline Ethyl ether & 1 pint & metal & $\begin{array}{l}\text { unopened, age } \\
\text { unknown }\end{array}$ \\
\hline \multicolumn{4}{|c|}{ RTL BUILDING ( 3000 AREA) } \\
\hline Isopropy] & $1 \mathrm{~kg}$ & glass & $\begin{array}{l}\text { at least } 21 / 2 \text { yrs } \\
\text { old, partialiy empty }\end{array}$ \\
\hline
\end{tabular}



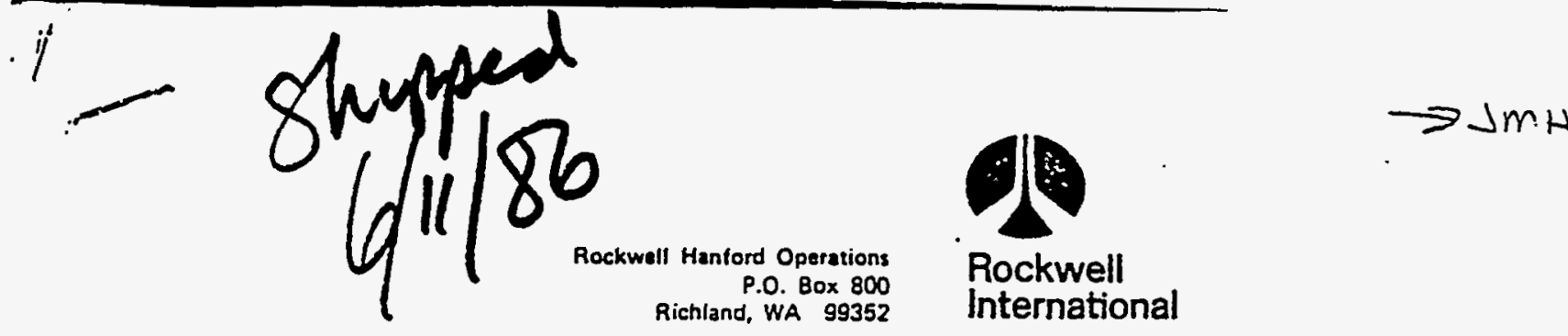

In reply, refer to letter $R 86-2632$

Ms. J. M. Hobbs

Pacific Northwest Laboratiory

Post Office Box 999 -

Richland, Washington 99352

Dear Ms. Hobbs:

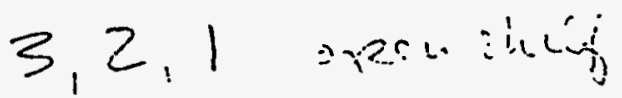

CHEMICAL WASTE DISPOSAL ANALYSIS NO. PNL-22-125

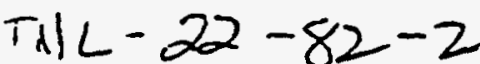

wost flam. Lis

Reference: Chemical Waste Disposai Requests 86-019, 86-020, 86-027, 86-028 and 86-029, April 30, 1986, J. M. Hobbs to

Solid Waste Processing and Disposal Unit

The Rockwell Hanford Operations' Solid Waste Processing and Disposal (SWP\&D) Unit has completed a waste disposal analysis for wastes identified in the reference. Instructions for waste packaging and disposal are:

General

A11 hazardous wastes must be packaged and transported according to Washington State Regulations WAC 173-303 and U. S. Department of Transportation (DOT) Regulations 49 CFR. Improperly packaged wastes will not be accepted by site disposal facility personnel and will be returned to you for corrections. These circumstances should, however, be prevented by the pre-shipment inspection made by our Unit personnel.

\section{Preparation for Shipment}

Wastes must be packaged, labeled and marked by the generator according to the instructions given in the attached disposal analysis. The instructions must comply with State of Washington and DOT regulations. Please note that markings must be legible, durable, and in a color which contrasts with the container. Labels are available as store stock items.

\section{Inspection and Manifests}

When the waste has been properly packaged, SWP\&D Unit personnel will make a pre-shipment inspection to verify compliance with the packaging instructions. Properly completed Uniform Hazardous Waste Manifest(s) will be delivered and initiated by the SWP\&D Unit representative upon satisfactory inspection. More than one manifest may be required, depending on shipping destinations and waste compatability. 
DISPOSAL ANALYSIS NO. PNL-22-125

THE FOLLOWING ARE HAZARDOUS WASTES WHICH ARE UNSTABLE OR EXPLOSIVE.

These wastes should be disposed by detonation. Please contact M. R. Romsos on 373-4032 to make further arrangements.

2. Benzene/butyl. lithium solution (86-028, \#7) $\begin{array}{ll}1 \text { qt } & (0.9 \mathrm{~kg})^{-}\end{array}$

2. Waste solvent: (86-019, \#8)

$1 \mathrm{qt} / \mathrm{kg})-H \Delta$

hexane/benzene/butyl lithium/ tetrahydrofuran

3. Tetrahydrofuran

$(86-019, \# 38)$

$\left.\begin{array}{l}1 \mathrm{gal} \\ (4 \mathrm{~kg})\end{array}\right) H(P A D S$

4. Chromium metal powder

(86-027, \#23)

116

5. Orạanic mixture:

(86-028, \#2)

$40 \%$ toluene

$20 \%$ ether

$5 \%$ benzene

$5 \%$ ethyl acetate

$30 \%$ petroleum ether

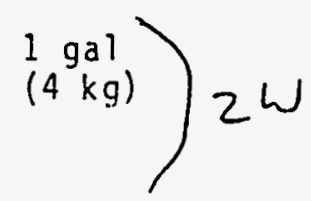

6. Organic mixture:

$50 \%$ heptane

$50 \%$ di-ethyl ether

(86-020, \#30)

$\left(\begin{array}{cc}0 a l \\ 4 & k 0)\end{array}\right) 2 w$

7. Organic mixture:

$78 \%$ ethyl ether

$22 \%$ allyl magnesium bromide

(86-019, \#7)

$\left.\begin{array}{l}1 \text { liter } \\ (1 \mathrm{~kg})\end{array}\right) 2 \omega$

8. Organic mixture:

$20 \%$ benzene

$20 \%$ ethyl acetate

$10 \%$ tetrahydrofuran

$10 \%$ toluene.

$10 \%$ ether

$1 \%$ hydrogen sulfide

$29 \%$ methanol

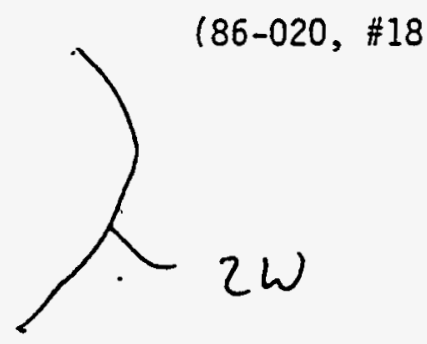

1 gal

$(4 \mathrm{~kg})$ 
Hevision to ENLLUSURE II (JU1Y 22, 1987 Letter)

CHEMICALS TQ GE DETONATED IN ADUUITIUN TO ENCLOSURE II LIST

August 25, 1987.

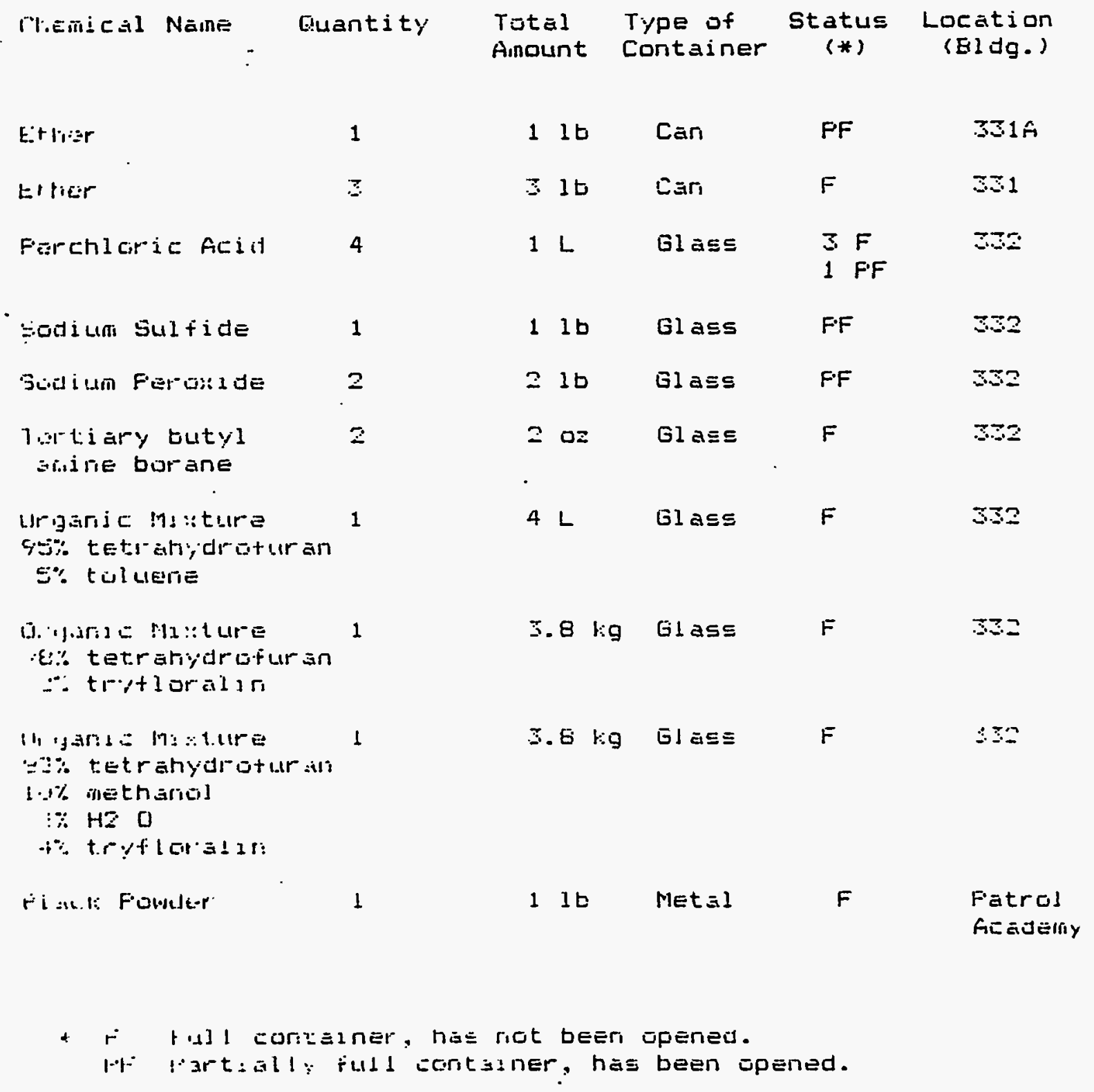




\section{ENCLOSURE II}

CHEMICALS TO BE DETONATED

\begin{tabular}{|c|c|c|c|c|c|}
\hline CHEMICAL NAME & QUANTITYY & TOTAL AMOUNT & CONTAINER & STATUS & LOCATION \\
\hline Tetrahyrofuran & 1 & $3.8 \mathrm{~K}$ & glass & $F$ & 331 Bldg. \\
\hline 1,4. - Dioxane & 1 & $1 \mathrm{~K}$ & glass & $F$ & 331 Bldg. \\
\hline $\begin{array}{l}\text { Boron trifluoride } \\
\text { ether complex }\end{array}$ & 1 & $.4 K$ & glass & PF & 332 Bldg \\
\hline 1,4-Dioxane & 1 & $.5 \mathrm{~K}$ & glass & $F$ & 332 Bldg. \\
\hline Tetrahyrofuran & 1 &. $\mathrm{IK}$ & glass & PF & $332 \mathrm{~B} 1 \mathrm{dg}$. \\
\hline $\begin{array}{l}\text { Hydrazine } \\
\text { monohydrate }\end{array}$ & 1 & $.5 K$ & glass & $F$ & 332 Bldg. \\
\hline $\begin{array}{l}\text { Boron trifluoride } \\
\text { methanol complex }\end{array}$ & 1 & $1 K$ & glass & PF & 332 Bldg. \\
\hline $\begin{array}{l}\text { Butyllithium/ } \\
\text { benzene mixture } \\
(25 \% / 75 \%)\end{array}$ & 1 & $.2 K$ & glass & $\mathrm{F}$ & 332 Bldg. \\
\hline $\begin{array}{l}\text { Boron trifluoride/ } \\
\text { methanol mixture } \\
(14 \% / 86 \%)\end{array}$ & 1 & $.05 \mathrm{~K}$ & glass & $F$ & 332 Bldg. \\
\hline $\begin{array}{l}\text { Boron trifluoride } \\
\text { ether complex }\end{array}$ & 1 & $.1 \mathrm{~K}$ & glass & PF & 332 Bldg. \\
\hline $\begin{array}{l}2,4 \text { Dinitropheny } \\
\text { hydrazine }\end{array}$ & 1 & $.025 K$ & plastic & $\mathrm{F}$ & $332 \mathrm{~B} 1 \mathrm{dg}$. \\
\hline Allyl ether $(100 \%)$ & 1 & $.0005 \mathrm{~K}$ & glass & $\mathrm{PF}$ & 332 B1dg. \\
\hline Triethyl aluminum & 1 & . . $3 \mathrm{~K}$ & metal & $\mathrm{PF}$ & 332 B1dg. \\
\hline Naphthacene & 1 & $.003 K$ & glass & PF & 332 Bldg. \\
\hline $\begin{array}{l}\text { 2-Methyl furan } \\
(100 \%)\end{array}$ & 1 & $.0005 K$ & glass & PF & 332 Bidg. \\
\hline
\end{tabular}


DON'T SAY IT - WRITE IT!!

June 23,1988

TO: Those Listed FROH: G. G. Heade $4 /$ Hald

CC: J. L. Davidson - DOE-RL/A5-55

R. L. Neison - DOE-RL/A5-55

L. G. Husen - DOE-RL/A5-55

GGII-File/lt

WESTINGHOUSE HANFORD COMPANY DETONATION OF EXPLOSIYE CHEHICALS SCHEDULED FOR JUNE 21,1988

Letter $\$ 8853769$ from R. E. Peterson to J. R. Patterson of Department of Energy - Richland Operations office (DOE-RL), Safety and Environment Division requested approval of the detonation of certain explosive chemicals scheduled for June 2l, 1988. The activity was approved by DOE on June 14, 1988. Pacific Northwest Laboratory requested that two additional containers of explosive chemicals be added to the detonation inventory. They are:

- 1 pint-size container of perchloric acid about $1 / 4$ full obviously old.

- 1 pint-size container of ether about $1 / 2$ full - obviously old.

After a phone consultation with Mr. J. L. Davidson of DOE-RL, Safety and Environment Division, he approved the addition of the two containers 1 isted above to the inventory of chemicals to be detonated.

This DSI serves to modify Enclosure II of Letter 8853769. This DSI should be attached to the letter.

Distribution

$\begin{array}{llll}\text { J. R. Be11 } & \text { R3-60 } & \text { G. G. Meade } & R 3-54 \\ \text { G. M. Christensen } & \text { R2-30 } & \text { J. H. Olson } & R 1-51 \\ \text { H. F. Daugherty } & \text { R2-28 } & \text { R. E. Peterson } & \text { R2-30 } \\ \text { B. G. Essary } & \text { SO-46 } & \text { M. R. Romsos } & \text { RI-51 } \\ \text { D. E. Good } & \text { S0-97 } & \text { E. L. Stairet } & \text { SO-46 } \\ \text { D. G. Harlow } & \text { R2-01 } & \text { S. A. Hever } & \text { B3-04 } \\ \text { W. M. Jacobi } & \text { B3-0I } & \text { D. D. Hodrich } & \text { R2-23 } \\ \text { D. W. Lindsey } & \text { R1-51 } & \text { D. L. Hegener } & \text { X6-18 }\end{array}$

tat 


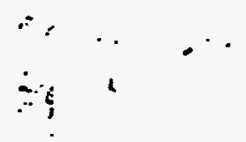

:

ENCLOSURE II

CHEMICALS TO BE DETONATED

CHEMICAL NAME QUANTITY IOTA AMOUNT CONTAINER. STATUS LOCATION .

1,4 - DIOXANE

Ethyl Ether

perchloric

Ethyl Ether

picky chloride - ap
5

1

$1 / 4$ pint

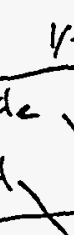

$2,500 \mathrm{ml}$. glass $/ 500 \mathrm{ml}$. PF

$3,000 \mathrm{ml}$. glass /1 gallon PF
$100 \mathrm{~N}$

332

- lot jar

litre

PAL

POL

$\dot{\leftrightarrow}$

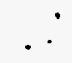




\section{- ENCLOSURE II}

\section{CHEMICALS TO BE DETONATED}

\begin{tabular}{|c|c|c|c|c|c|}
\hline CHEMIGAL- NAME QUA & ANTITYY & TOTAL AMOUNT & CONTAINER & STATUS & LOCATIO \\
\hline $\begin{array}{l}\text { Lithium } \\
\text { Triethylborohydride } \\
\text { (PNL-24-556) }\end{array}$ & 1 & $0.9 \mathrm{~kg}$ & 1 quart & $F$ & 332 \\
\hline $\begin{array}{l}\text { Ethyl Ether } \\
\text { (PNL-24-737) }\end{array}$ & 3 & $1.5 \mathrm{Kg}$ & 1 pint & $F$ & 332 \\
\hline Ethyl Ether & 4 & $10.8 \mathrm{Kg}$ & 4 liter & $F$ & 332 \\
\hline $\begin{array}{l}2,2^{\prime}, 4,4^{\prime}, 6,6^{\prime}- \\
\text { hexanitrodiphenyl am }\end{array}$ & $\begin{array}{c}1 \\
\text { nine }\end{array}$ & $0.05 \mathrm{~kg}$ & 4 . ounce & PF & 332 \\
\hline $\begin{array}{l}\text { Picryl Chloride } \\
\text { (PNL-24-764) }\end{array}$ & 1 & $0.025 \mathrm{~kg}$ & 25 grams & $F$ & 332 \\
\hline $\begin{array}{l}\text { Dioxane } \\
\text { (PNL-24-764) }\end{array}$ & 1 & $0.5 \mathrm{Kg}$ & 500 grams & $F$ & 332 \\
\hline
\end{tabular}


DISPOSAL ANALYSIS NO. PNL-24-737

\section{REACTIVE CHEMICAL}

The following chemical has been determined to be reactive and shall NOT be shipped to the 616 Nonradioactive Dangerous Waste Storage Facility.

Item $\# 1290$ ( 3 cans of .ethyl ether, 1 pound each)

Please contact $M$. R. Romsos on 373-4032 to discuss a possible direct of shipment of this waste or onsite detonation. 
DISPOSAL ANALYSIS NO. PNL-24-764

\section{REACTIVE WASTE}

The following item is considered to be explosive and cannot be shipped off-site. Please contact M. R. Romsos on 373-4032 to make arrangements for on-site detonation.

$\begin{array}{llllrr}\# 1517 & \text { picryl chloride } & 1 & \text { glass } & 25 \mathrm{~g} & .025 \mathrm{~K} \\ \# 1340 \text { dioxane } & : & 1 & \text { glass } & 500 \mathrm{~g} . & .5 \mathrm{~K}\end{array}$


Memo to Mike Romsos

from Kathy Poston

Re: items for detonation for December detonation

The following items have either been designated for detonation by Westinghouse, or have characteristics which make them good candidates for detonation:

\begin{tabular}{|c|c|c|c|}
\hline Item & $\begin{array}{l}\text { Number } \\
\text { of } \\
\text { containers }\end{array}$ & Chemical & Quantity \\
\hline 1 & $1-1 \mathrm{Kg}$ & $\begin{array}{l}\text { Lithium } \\
\text { Triethylborohydride }\end{array}$ & $.9 \mathrm{Kg}$ \\
\hline 2 & 3-1 Pint & Ethyl Ether & $1.5 \mathrm{Kg}$ \\
\hline 3 & 4-4 Liter & Ethyl Ether & $10.8 \mathrm{Kg}$ \\
\hline 4 & $4-0 z$ & $\begin{array}{l}2,2^{\prime}, 4,4^{\prime}, 6,6^{\prime}- \\
\text { hexanitrodiphenylam }\end{array}$ & $0.05 \mathrm{Kg}$ \\
\hline
\end{tabular}

Item numbers 1 and 2 have been designated by Westinghouse for detonation, item 3 is at least five years old, and item 4 is very old, and shock sensitive, used as a booster explosive. If you have any questions, give me a call at $376-3752$.

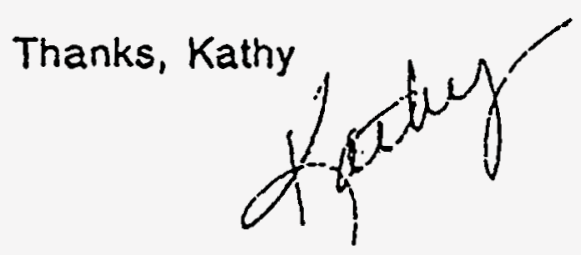




\section{- ENCLOSURE II}

CHEMICALS TO BE DETOHATED

\section{CHEMLCAL NAME QUANTITY IOTAL AMOUNT CONTAINEB STATUS LOCATION}

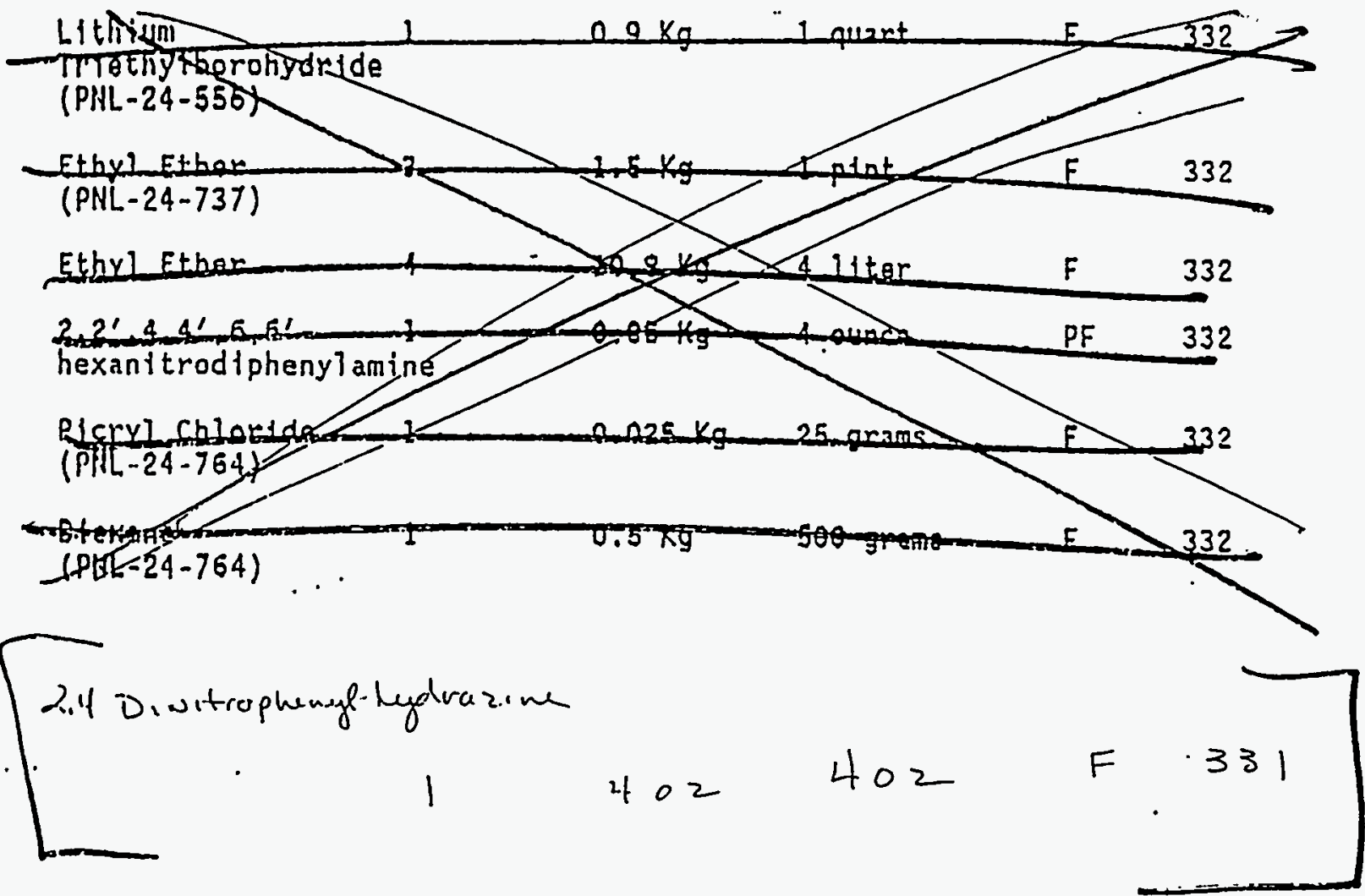


(2) Westinghouse

Internal

Hanford Company

Memo

From: Site Hazardous Waste Engineering Support Unit

Phone: $3-3516$ 2750E/AI19/200E RI-51

Date: February 22, 1989

SUbject: GENERATOR LOGBOOK NUMBER 89-013, SITE HAZARDOUS WASTE ENGINEERING SUPPORT UNIT LOGBOOK NUMBER PNL-25-114

To:

K. A. Poston P7-68

CC: M. R. Romsos R2-82

RLG: File/LB Wh

The following items are to be detonated on site:

\begin{tabular}{|c|c|c|c|c|}
\hline Item & Containers & $\begin{array}{l}\text { Total } \\
\text { wt. }\end{array}$ & Chemical & $\begin{array}{l}\text { Waste } \\
\text { Codes } \\
\end{array}$ \\
\hline 2053 & $\begin{array}{l}2 \text { ea } 25 \mathrm{~g} \text {, } \\
5 \text { ea } 4 \mathrm{oz}\end{array}$ & $.2 \mathrm{~K}$ & 2,4-dinitrophenylhydrazine & $\begin{array}{l}\text { DO03 } \\
\text { WT02 }\end{array}$ \\
\hline 2054 & $\begin{array}{l}8 \text { ea } 1 \text { pt, } \\
1 \text { ea } 1 \text { oz glass }\end{array}$ & $s^{7 k}$ & perchloric acid (70\%) & $\begin{array}{l}\text { WTO2 } \\
\text { D001 } \\
\text { D002 } \\
\text { D003 }\end{array}$ \\
\hline 2055 & $\begin{array}{l}1 \text { ea } 1 \text { qt } \\
\text { metal }\end{array}$ & $1 \mathrm{~K}$ & ethyl ether, anhydrous & $\begin{array}{l}U 117 \\
0003\end{array}$ \\
\hline 2056 & $\begin{array}{l}2 \text { ea } 1 \mathrm{pt} \\
\text { cardboard }\end{array}$ & $.45 \mathrm{~K}$ & benzoyl peroxide & $\begin{array}{l}\text { D001 } \\
\text { D003 }\end{array}$ \\
\hline 2057 & $\begin{array}{l}2 \text { ea } 1 \text { gal } \\
\text { glass }\end{array}$ & $7.6 \mathrm{~K}$ & tetrahydrofuran & $\begin{array}{l}\text { U213 } \\
\text { WT02 } \\
\text { D001 } \\
\text { D003 }\end{array}$ \\
\hline 2058 & $\begin{array}{l}1 \text { ea } 1 \mathrm{pt}, \\
1 \text { ea } 1 \mathrm{gal}, \mathrm{gl}\end{array}$ & $\begin{array}{l}3 \mathrm{~K} \\
\text { ass }\end{array}$ & dioxane & $\begin{array}{l}\text { U108 } \\
\text { WTO1 } \\
\text { WCO1 } \\
\text { DO01 } \\
\text { D003 }\end{array}$ \\
\hline 2059 & $\begin{array}{l}1 \text { ea } 200 \mathrm{~g} \\
\text { glass inside } 1 \mathrm{~s}\end{array}$ & $\begin{array}{l}200 \mathrm{~g} \\
\text { ead box }\end{array}$ & $\begin{array}{l}2,4,6,2^{\prime}, 4^{\prime}, 6^{\prime}- \\
\text { hexanitrodiphenylamine }\end{array}$ & D003 \\
\hline
\end{tabular}

If you have any questions or concerns on the subject, please contact me on $3-3516$.

R.1. Hanberg

R. L. Granberg

Technician

cmc 


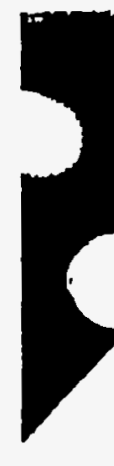

SPOSAL ANALYSIS NO. PNL-25-054

\section{SHOCK SENSITIVE/EXPLOSIVE}

The following waste is shock sensitive and must be disposed of by contacting M. R. Romsos on 373-4032.

\#1928 Hydrazine, monohydrate 21 qt glass .8 K 
OSAL ANALYSIS NO. PNL-24-878

\section{SHOCK SENSITIVE}

Waste 11 sted below shall be disposed of by contacting $M$. R. Romsos on 373-4032, for possible onsite detonation or direct offsite shipment.

$\$ 1691$ ethyl ether, anhydrous

$\$ 17.05$.

$\$ 1706$

$\$ 1719$ sodium. sulfide . tetrahydrofuran $2,2^{\prime}, 4,4,6,6^{\prime}$ hexanitrodiphenylamine
4, 1 gal glass containers

4. $2 \mathrm{Kg}$ plastic containers

2, 500 mi glass

1,4 oz glass
$10.6 K$

$8 K$

$1 K$

$0.05 K$

\section{WATER REACTIVE}

Haste listed below is water reactive and shall be stored at the generating facility. Contact M. R. Romsos on 373-4032 to arrange for direct offsite shipment.

$\$ 1718$ waste calcium carbide 2 , metal 5 1b cans $4.5 \mathrm{~K}$ 
PNL $-25-209$

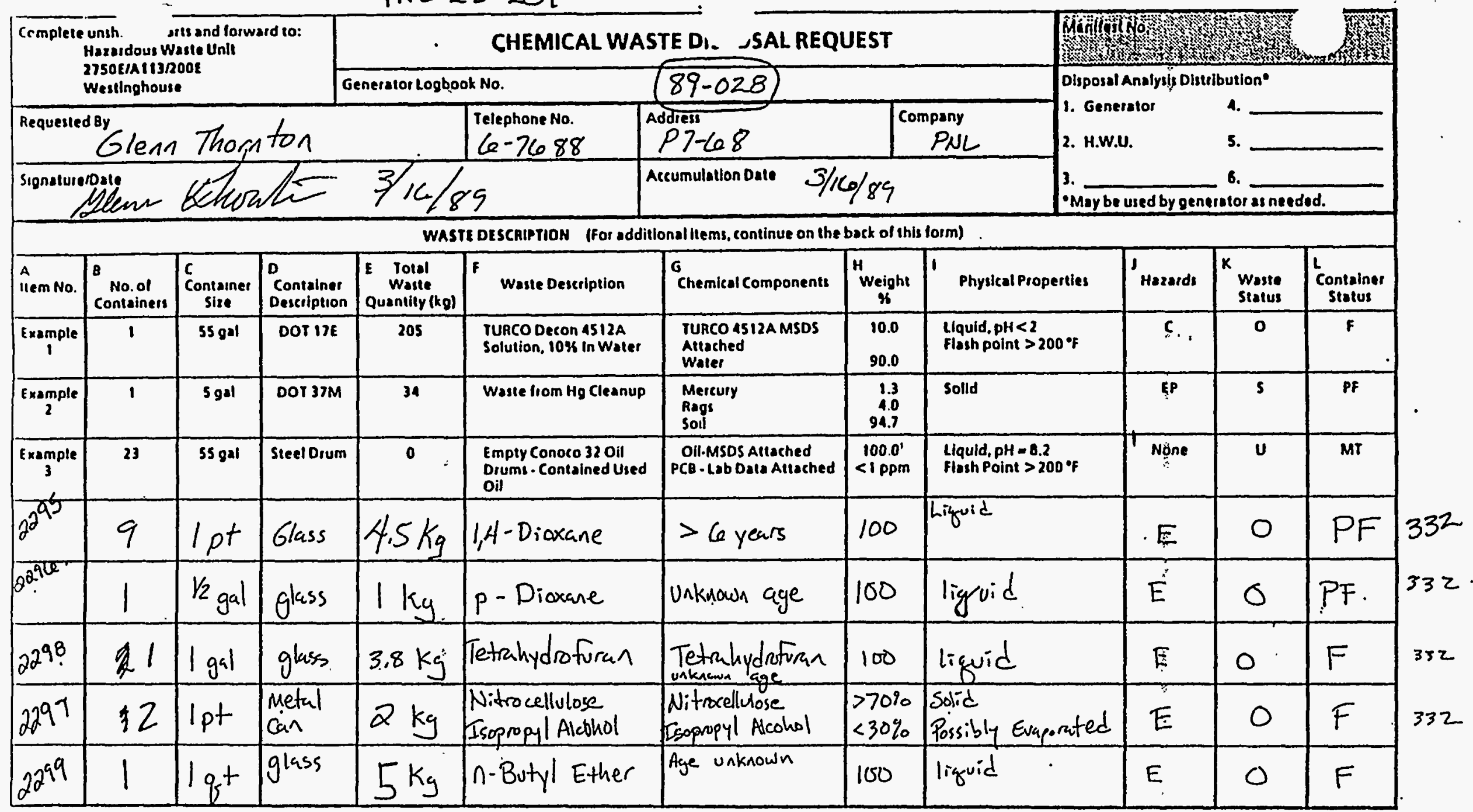

\section{INSTRUCTIONS}

Accumulatlon Dale - List the accumulation date of the oldest waste

Column A - llem Number - Item number for each unique waste.

Column B - Number of Contalners - Number ol corresiners al a unique waste 10 be disposed

Column C - Container Slze-Size of containers specilied in Column B. II multiple consainer sizes,

Column D - Contalner Descriplion - Specily container's DOT specilication II non.Dor contalner or unk nown. specily type. e g steel dium

Column E - Tolal Waste Quantily - Tolal waste quanlify (in kilogiams only) ol each unique waste to be disposed

Columnf - Waste Description-Specily lrade name or general description ol each unique waste If waste material is a paint, specily color Jor evaluation of pigments.

Column 6 - Chemleal Components - List all organic and inorganic components of the unique waste using specilic chemical names Allach Muleinal Salety Data Slicels, analyital dala, or othel documenis to adequalely descrilie the composilion of the waste
Column H - Welght (\$6) - for each waste component indicate percent or range af percents in which the component is present In the waste. Tiace amounts of pestleides. heiblcides. heary melals and $P C B$ 's should be specltied. Components must add up to 1008 including water, earth. or other componenits. II \& unit other than percent Is used, Indicate the unit. When possible; provlde test results or other documentation to verity percentages.

ColumnI - Physlcal Pioperlles - Indicate whether Solid (S), Llquid (L), or Gas (G) or any combination ol theso phases, also indicate pH and liash point.

Column) - Ilexards - Indicalo whother wasso is Corrosive (C). Ignitable (I). Reactive (R), Toxic (T). Explosive (E). Persistent (P), EP Toxic (EP) or Carclinogenle $(X)$

Column K - Wailo Stalus - indlcate whether waste is: Reacted (Rx). Treated (T), New (M), Uned (U). Old (or expired) (O), Spill Material (S).

Column L - Conlalner Stalus - Indicate whether contalner ls: Full (F), Partlally full (PF), Empty ( $\&$ i in. in 55 Gal Drums) (MT). Triple Rinsed (IR). 
PNL $-25-210$

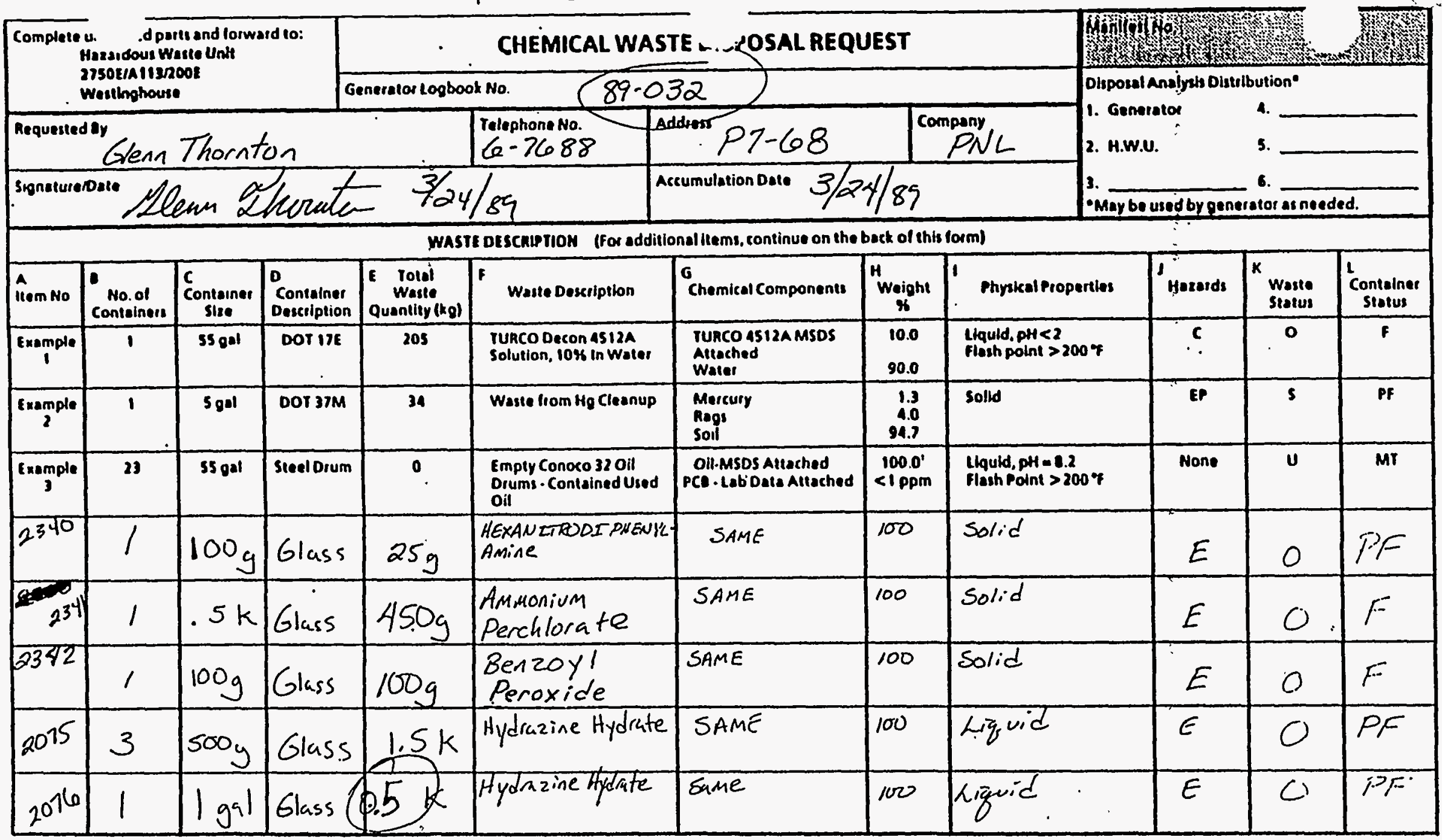

\section{IMSTAUCTIOHS}

Accumulation Date - List the accumulation date of the oldest waste

Column - Mem Humber - Ilem number lor cach unique waste

Cohmn : - Mumber of Conlaineis - Mumber of contaness ol a unique waste to be disposed

Cotumn C - Contelinat slise-size ol containers specified in Column 8. 11 multiple container sizes.

Cotumn D - Contalnei Descilption - Specily contatneis por specilication II non-Dot containes of unk nown, specily type. 0 steel dium

Cohumn E - Tolal Waste Quentliy - Total wasle quantity (in kilogiams only) ol each unique waste 10 be disposed

Cotumn - Waste Desciiplion-Specily trade name or general description of each unique wasse II waste material is a paint. specily color lor evaluation of pigments.

Cotumn G - Chemkal Components - tist all organic and inorganic components of the unique waste using specilic chemical names Altach Moterial Salety Data Sheets. enalytical data, ol other documents to adequalely describe the composition of the waste

Column H - Welght (H) - For each waste component Indicate parcent ol range of percents in which the component is present in the waste. Trace amounts of pesticldes. herbieldes, heaur mets an herbicldas, heaur metals and ther documentetion to verity peicentages.

Columnl - Physteal Propertles - Indicate whethei Solid (S), Llquid (L), or Gas (G) or any combination of these phases, also indicate pH and flastip point.

ColumnI - Hazards - Indicale whether waste is Conoslve (C), lanilable (I), Reactive (R), Toxic (T), Explosive (E). Persistent (P), EP Toxic (EP) or Carcinogenic (X).

Column K - Watto Status - Indlcate whether waste is: Reanted (RX), Treated (T), Now (N), Used (U). Old (or expired) (0), Spill Material (S).

Columne - Conle!ner Stalus - Indicule whother container ls: full (F), Partially full (PF), Empty ( $<$ t in in 55 Gal Drums) (MT), Triple Rinsed (IA). 


\begin{tabular}{|c|c|c|c|c|c|c|c|c|c|c|c|}
\hline IIem no & {$\left[\begin{array}{c}\ldots \\
\text { contaners }\end{array}\right.$} & 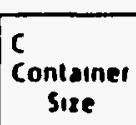 & $\begin{array}{l}\begin{array}{c} \\
\text { contaner } \\
\text { Destription }\end{array} \\
\end{array}$ & 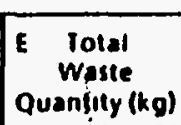 & Wasste Description & ...emtest Componenents & welght & Physical Properties & 'Masaids & sescius & $\begin{array}{l}t_{\text {Contines }} \\
\text { statust }\end{array}$ \\
\hline 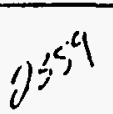 & 1 & | gal & Gluss & $4 \mathrm{~kg}$ & Tetrahydro furan & Tetrahydoforan & 100 & liquid & $E$ & 0 & $F$ \\
\hline & & & & & & & & & & & \\
\hline & & & & & & & & & & & \\
\hline & & & & & & & & & & & \\
\hline & & & & & & & & & & & \\
\hline & & & & & & & & & & & \\
\hline & & & & & & & & & & & \\
\hline & & & & & & & & & & & \\
\hline & & & & & & & & & & & \\
\hline & & & & & & & & & & & \\
\hline & & & & & & & & & & & \\
\hline & & & & & & & & & & & \\
\hline & & & & & & & & & & & \\
\hline & & & & & & & & & & & \\
\hline & & & & & & & & & & & \\
\hline
\end{tabular}


(W) Westinghouse

Hanford Company

From: Site Hazardous Waste Engineering Support Unit

Phone: $\quad 3-3516$ 2750E/A119/200E Rl-51

Date: March 6, 1989

Subject: GENERATOR LOGBOOK NUMBER 87-257, SITE HAZARDOUS WASTE ENGINEERING SUPPORT UNIT LOGBOOK NUMBER HHC-25-134

To:

M. E. Burnside $\quad L 6-40$

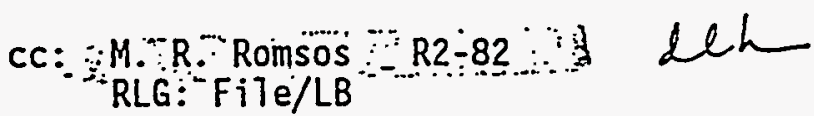

The following item is to be detonated on site:

- Container Total wt Chemical Haste Codes

$1 \mathrm{ea}, 5 \mathrm{gal}, \mathrm{DM} \quad 0.5 \mathrm{~K} \quad$ Sodium potassium alloy D001, D003

If you have any questions or concerns on the subject, please contact me on $373-3516$.

R.t. Khanberg

R. L. Granberg

Technician

cmc 
ERCLOSURE II

CHEMICALS TO BE DETONATED

\begin{tabular}{|c|c|c|c|c|c|}
\hline CHEMICAL NAME QUAR & WIITY & JTAL AMOUNT & CONTAINER & STATUS & LOCATION \\
\hline $\begin{array}{l}1,4-\text { DIOXANE } \\
(\text { PNL-25-209) }\end{array}$ & 11 & $5.45 \mathrm{Kg}$ & $1-p t$ & PF & 332 \\
\hline $\begin{array}{l}\text { p-Dioxane } \\
(\text { PNL-25-209) }\end{array}$ & 1 & $1.0 \mathrm{Kg}$ & $1 / 2$-gal & PF & 332 \\
\hline $\begin{array}{l}\text { Tetrahydrofuran } \\
\text { (PNL-25-209) }\end{array}$ & 1 & $3.8 \mathrm{~kg}$ & $1-g a 1$ & $\mathbf{F}$ & 332 \\
\hline $\begin{array}{l}\text { Nitrocellulose/ } \\
\text { Isopropyl Alcohol (P }\end{array}$ & ${ }^{2}$ PNL-25-209) & $2.0 \mathrm{~kg}$ & $1-p t$ & $F$ & 332 \\
\hline $\begin{array}{l}\text { n-Butyl Ether } \\
\text { (PNL-25-209) }\end{array}$ & 1 & $5.0 \mathrm{Kg}$ & $1-q t$ & $F$ & 332 \\
\hline $\begin{array}{l}\text { Dibutyl Tetra } \\
\text { Ethylene Glycol (PNL }\end{array}$ & 1 & $2.0 \mathrm{~kg}$ & 2-1iter & $F$ & 332 \\
\hline $\begin{array}{l}\text { 2-Methoxyethylether } \\
\text { (PNL-25-209) }\end{array}$ & 1 & $1.0 \mathrm{Kg}$ & 1-liter & $F$ & 332 \\
\hline $\begin{array}{l}\text { n-Propylether } \\
\text { (PNL-25-209) }\end{array}$ & 1 & $0.5 \mathrm{~kg}$ & $1-p t$ & $F$ & 332 \\
\hline $\begin{array}{l}\text { 1,3,5-Trinitro } \\
\text { Benzene (PNL-25-209) }\end{array}$ & 1 & $0.05 \mathrm{Kg}$ & $50-9$ & $F$ & 332 \\
\hline $\begin{array}{l}\text { 1, 4-Diethoxybutane } \\
\text { (PNL-25-209) }\end{array}$ & 1 & $0.5 \mathrm{Kg}$ & $1-p t$ & $F$ & 332 \\
\hline $\begin{array}{l}\text { 2-Ethoxybytanone } \\
\text { (PNL-25-209) }\end{array}$ & 1 & $0.1 \mathrm{~kg}$ & $100-g$ & $F$ & 332 \\
\hline $\begin{array}{l}\text { Dimethoxypropane } \\
\text { (PNL-25-209) }\end{array}$ & 1 & $0.025 \mathrm{Kg}$ & $25-g$ & $F$ & 332 \\
\hline
\end{tabular}

Note: $F=$ full, PF = partially full 
CHEMICALS TO BE DETOANTED (Continued)

CHEMICAL NAME QUANTITY TOTAL AMOUNT CONTAINER STATUS LOCATION

\begin{tabular}{|c|c|c|c|c|c|c|}
\hline $\begin{array}{l}\text {-Diothyteneglyco } \\
\text { (PAL-25-209) }\end{array}$ & In & o.ly list once! & $\begin{array}{l}25-9 \\
4-28-89\end{array}$ & $F$ & 332 & \\
\hline $\begin{array}{l}\text { Di-tert-buty1- } \\
\text { ether (PNL-25-209) }\end{array}$ & $1^{2}$ & $0.025 \mathrm{~kg}$ & $25-g$ & $F$ & 332 & \\
\hline $\begin{array}{l}2,4,6-\text { Trinitro- } \\
\text { m-toluene (PNL-25-20 }\end{array}$ & 1 & $0.1 \mathrm{Kg}$ & $100-9$ & $F$ & 332 & \\
\hline $\begin{array}{l}\text { Hexanitrodiphenyl- } \\
\text { amine (PNL-25-210) }\end{array}$ & 1 & $0.025 \mathrm{Kg}$ & $100-9$ & $P F$ & 332 & \\
\hline $\begin{array}{l}\text { Ammonium } \\
\text { Perch) orate (PNL-25- }\end{array}$ & $\begin{array}{l}1 \\
-210)\end{array}$ & $0.45 \mathrm{~kg}$ & $500-g$ & $F$ & 332 & \\
\hline $\begin{array}{l}\text { Benzoyl Peroxide } \\
\text { (PNL-25-210) }\end{array}$ & 1 & $0.1 \mathrm{~kg}$ & $100-9$ & $F$ & 332 & \\
\hline $\begin{array}{l}\text { Hydrazine Hydrate } \\
\text { (PNL-25-210) }\end{array}$ & 3 & $1.5 \mathrm{Kg}$ & $500-g$ & PF & 332 & \\
\hline $\begin{array}{l}\text { Hydrazine Hydrate } \\
(\text { PNL-25-210) }\end{array}$ & 1 & $0.5 \mathrm{Kg}$ & $1-g a l$ & $P F$ & 332 & \\
\hline $\begin{array}{l}\text { Tetrahydrofuran } \\
\text { (PNL-25-210) }\end{array}$ & 1 & $4.0 \mathrm{Kg}$ & $1-g a l$ & $F$ & 332 & \\
\hline $\begin{array}{l}\text { Sodium-Potassium } \\
\text { Alloy (NaK) (WHC-25- }\end{array}$ & $\begin{array}{l}1 \\
-134)\end{array}$ & $0.5 \mathrm{Kg}$ & $5-g a l$ & PF & $3718 \mathrm{~F}$ & \\
\hline Picryl Chloride & 1 & $0.06 \mathrm{k}$ & $4-0 z$ & $P F$ & 332 & $\begin{array}{l}500 \\
1-2589\end{array}$ \\
\hline
\end{tabular}

Note: $F=$ full, PF = partially full 
From: Site Hazardous Waste Engineering Support

Phone: $\quad 3-3516$ 2750E/A119/200E/Rl-51

$13841-89-022$

Date: April 19, 1989

Subject: GENERATOR LOG \$89-028, SHWES LOG \#PNL-25-209

To:"

G. T. Thornton : P7-68.
cc:

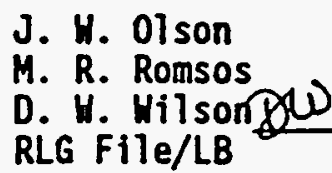
R2-82
R2-82
R1-51
RLG File/LB

The following items are to be detonated on site:

\begin{tabular}{|c|c|c|c|c|}
\hline Item & Containers & Total $W_{t}$. & Chemical & Waste Codes \\
\hline 2295 & 11 ea, 1-pt glass & $5.0 \mathrm{~K}$ & 1,4-dioxane & $\begin{array}{l}\text { WT01, WCO1, } \\
\text { D001, D003 }\end{array}$ \\
\hline 2296 & l ea, 1 -gal glass & $1 K$ & p-dioxane & $\begin{array}{l}\text { WTO1, HCO1 } \\
\text { D001, D003 }\end{array}$ \\
\hline 2298 & 1 ea, l-gal glass & $3.8 K$ & tetrahydrofuran & $\begin{array}{l}\text { U213, WTO2 } \\
\text { D001 }\end{array}$ \\
\hline 2297 & 2 ea, 1-pt metal & $2 K$ & $\begin{array}{l}\text { nitrocellulose in } \\
\text { isopropyl alcohol }\end{array}$ & $\mathrm{D} 001, \mathrm{D} 003$ \\
\hline 2299 & l ea, l-qt glass & $.5 \mathrm{~K}$ & n-butyl ether & $\begin{array}{l}\text { IT02, D001 } \\
\text { D003 }\end{array}$ \\
\hline 2301 & $1 \mathrm{ea}, 1-1$ glass & $1 K$ & $\begin{array}{l}\text { 2-methoxy ethyl } \\
\text { ether }\end{array}$ & 0003 \\
\hline 2302 & 1 ea, 1-pt glass & $.5 \mathrm{~K}$ & n-propyl ether & D001, D003 \\
\hline 2303 & $1 \mathrm{ea}, 50-\mathrm{gm}$ glass & $.05 \mathrm{~K}$ & $\begin{array}{l}\text { 1,3,5-trinitro- } \\
\text { benzene }\end{array}$ & D003 \\
\hline 2309 & $1 \mathrm{ea}, .1-\mathrm{K}$ glass & $.1 K$ & $\begin{array}{l}2,4,6 \text {-trinitro- } \\
\text { m-toluene }\end{array}$ & $\begin{array}{l}\text { HT02, D001 } \\
\text { D003 }\end{array}$ \\
\hline 3691 & 1 ea, 4-oz glass & $.06 \mathrm{~K}$ & picryl chloride & $\mathrm{HPO1}, \mathrm{DO03}$ \\
\hline 2300 & 1 ea, 2-1 glass & 2.K & $\begin{array}{l}\text { dibutyl tetra- } \\
\text { ethylene glycol }\end{array}$ & $N / A$ \\
\hline 2304 & 1-ea, 1-pt glass & $.5 \mathrm{~K}$ & diethoxybutane & $N / A$ \\
\hline
\end{tabular}


G. T. Thornton

13841-89-022

Page 2

April 19, 1989

Item 1 Containers

Total Wt. Chemical

Waste Codes

2305

1 ea,: 1-K glass

$.1 \mathrm{~K}$

2-ethoxybutanone

N/A

2306

1 ea, .025-K glass

$.025 \mathrm{~K}$ dimethoxypropane

N/A

2308

$1 \mathrm{ea}, .025-\mathrm{K}$ glass $.025 \mathrm{~K}$ ditertbuty] ther

N/A

Contact M. R. Romsos on 373-4032 for any further instructions.

Items $\$ 2307$ and $\$ 3692$ are being deleted from the Chemical Waste Disposal Request because the reference material lists no acute hazards.

If you have any questions or concerns, please contact me on 373-3516.

R.L. Granbey

R. L. Granberg, Technician

Site Hazardous Waste

Engineering Support

rjh 
From: Site Hazardous Waste Engineering Support

Phone: $\quad 3-3516$ 2750E/A119/200E/R1-51

$13841-89-018$

Date: April 4, 1989

Subject: GENERATOR LOG \#89-032, SHHES LOG \#PNL-25-210

To:

G. T. Thornton $\quad$ P7-68
cc:
H. R. Romsos R2-82
RLG File/LB

The following items are to be detonated onsite:

\begin{tabular}{|c|c|c|c|c|c|}
\hline Item \# & Conta & iners & Iotal Wt. & Chemical & $\begin{array}{l}\text { Wast } \\
\text { Codes }\end{array}$ \\
\hline 2340 & $\begin{array}{l}1 \text {-ea } \\
\text { glass }\end{array}$ & $100 \mathrm{~g}$ & $.025 \mathrm{~K}$ & hexadinitrophenylamine & 0003 \\
\hline 2341 & $\begin{array}{l}1 \text {-ea } \\
\text { glass }\end{array}$ & $.5 \mathrm{~K}$ & $.45 K$ & ammonium perchlorate & $\mathrm{D} 003$ \\
\hline 2342 & $\begin{array}{l}\text { 1-ea } \\
\text { glass }\end{array}$ & $100 \mathrm{~g}$ & $.1 \mathrm{~K}$ & benzoyl peroxide & 0003 \\
\hline 2359 & $\begin{array}{l}1 \text {-ea } \\
\text { glass }\end{array}$ & $1 \mathrm{gal}$ & $4.0 \mathrm{~K}$ & tetrahydrofuran & $\begin{array}{l}\text { U213 } \\
\text { WT02 } \\
\text { D001 } \\
\text { D003 }\end{array}$ \\
\hline
\end{tabular}

Contact M. R. Romsos on 373-4032 for further instructions.

Items \#2075 and 2076 will be put on a chemical waste disposal analysis as this unit believes these should be shipped offsite for disposal.

If you have any questions or concerns on the subject, please contact me on $373-3516$.

R. L. Thanbery

R. L. Granberg

Technician

rjh 
From: Site Hazardous Waste Engineering Support Unit

Phone: $3-3516,2750 E / A 119 / 200 E$ RI-51.

Date: March 6, 1989

SUbject: GENERATOR LOGBOOK NUMBER 87-257, SITE HAZARDOUS WASTE ENGINEERING SUPPORT UNIT LOGBOOK NUMBER WHC-25-134

To: M. E: Burnside $\quad$ L6-40

CC: M. R. Romsos - R2-82

RLG: File/LB

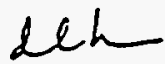

The following item is to be detonated on site:

Container Total wt Chemical Waste Codes

$1 \mathrm{ea}, 5 \mathrm{gal}, \mathrm{DM} \quad 0.5 \mathrm{~K} \quad$ Sodium potassium alloy D001, D003

If you have any questions or concerns on the subject, please contact me on 373-3516.

R.1. Khanberg

Technician

$\mathrm{cmc}$ 
Please print or type. (Form designed lor use on elite (12-pitch) typewriter.)

Form Approved OMB No. 2050-0039 Expires 9-30-88

\begin{tabular}{|c|c|c|}
\hline $\begin{array}{l}\text { UNIFORM HAZARDOUS } \\
\text { WASTE MANIFEST } \\
\text { (Continuation Sheet) }\end{array}$ & $\begin{array}{l}\text { 21. Generator's US EPA ID No. } \\
\text { HA } 7890008967\end{array} \quad \cdot \begin{array}{c}\text { Manifest Document Na } \\
\vdots\end{array}$ & 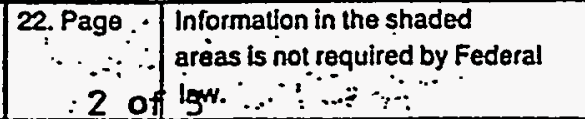 \\
\hline $\begin{array}{l}\text { Generator's Name } \\
\text { DEPARTMENT OF ENE } \\
\text { P.O. BOX 550; } 240 \\
\text { PHONE }(509) \cdot 373-4\end{array}$ & $\begin{array}{l}\text { RGY, RICHLAND OPERATIONS } \\
1 \cdot \text { STEVENS DR, }-R 2-82, \cdot \text { RICHLAND, HA } 9935 \\
032 \cdot \text { OR (509) 375-5491, -att: -MR ROHSOS }\end{array}$ & 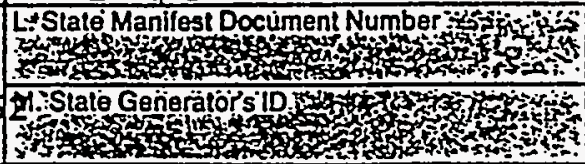 \\
\hline 24. Transporter $\cdots$ Company $\mathrm{Na}$ & . 25. US EPA ID Number... & 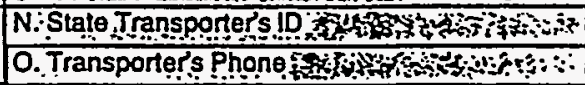 \\
\hline 26. Transporter ___ Company Na & 27. US EPA ID Number & 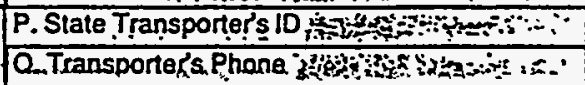 \\
\hline
\end{tabular}

\section{US DOT Description (Including Proper Shipping Name, Hazard Class, and ID Number)}

a. $\quad \frac{\mathrm{X}}{\mathrm{X}}$ WASTE FLAMMABLE LIQUID, N.0.S.

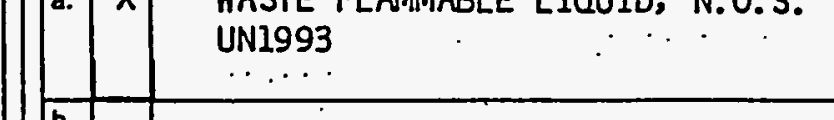

$\int$

$a$
$E$
$N$
$E$
$R$

$T$
0
0
$R$

d.

c.
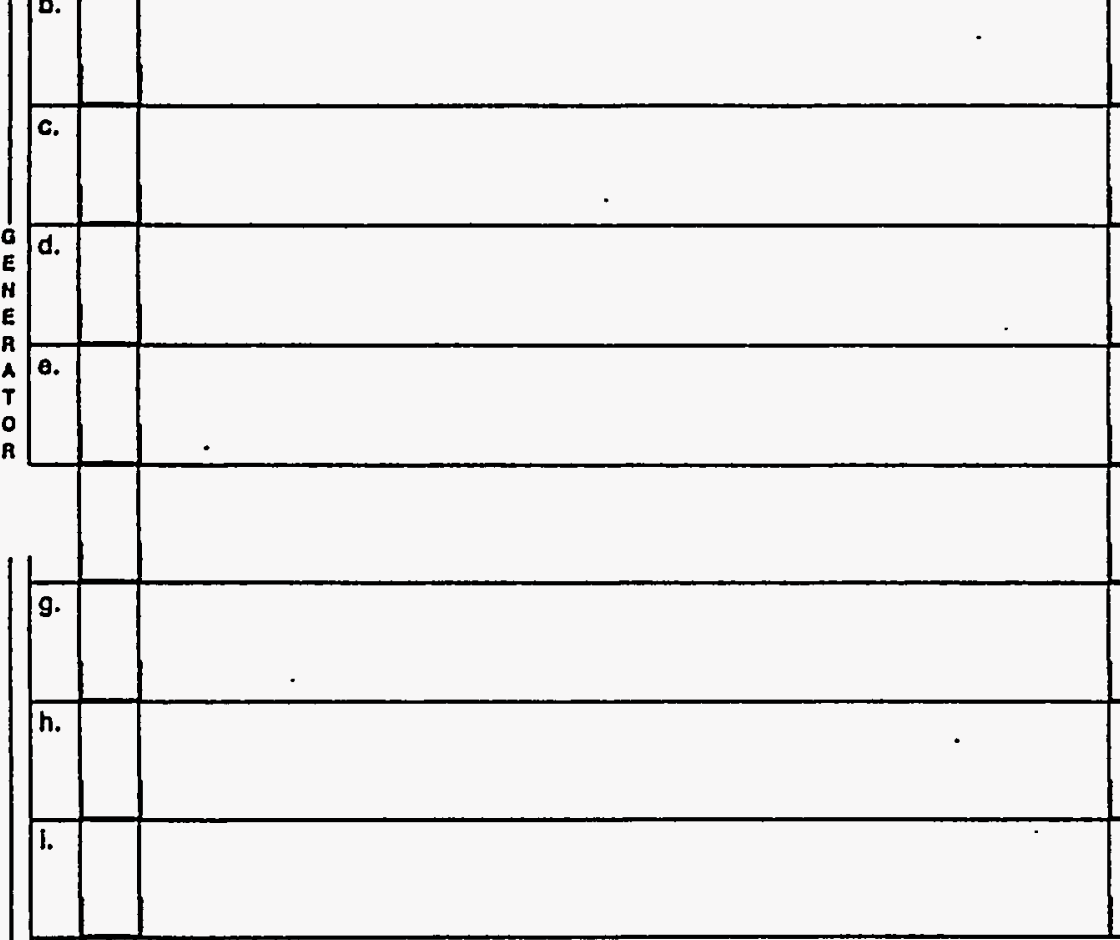

S.Additional Descriptions for Materials Listed Above ,

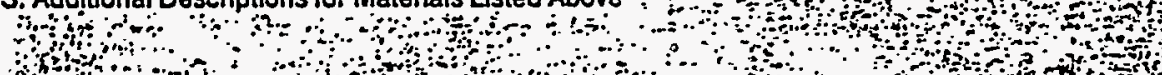

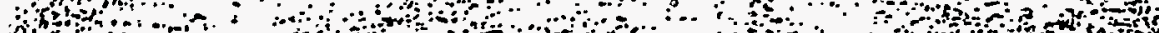

-

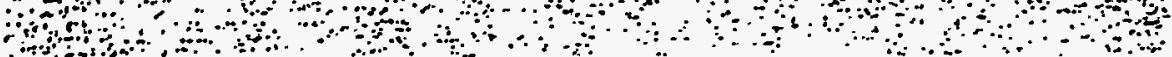

32. Special Handling Instructions and Additional Information

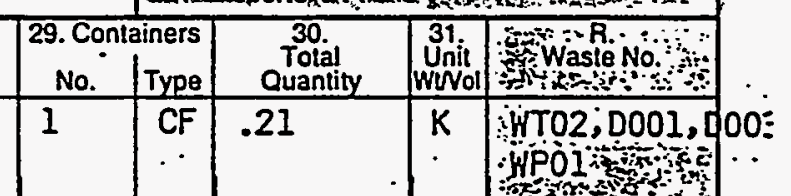

\begin{tabular}{r|r|r|r}
\hline & & & \\
\hline
\end{tabular}

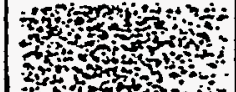

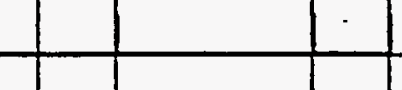

sisting

T:Handling Codes for Wastes Listed Above it

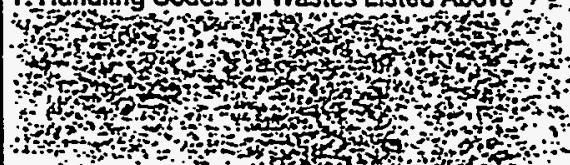

ifon (20)

1

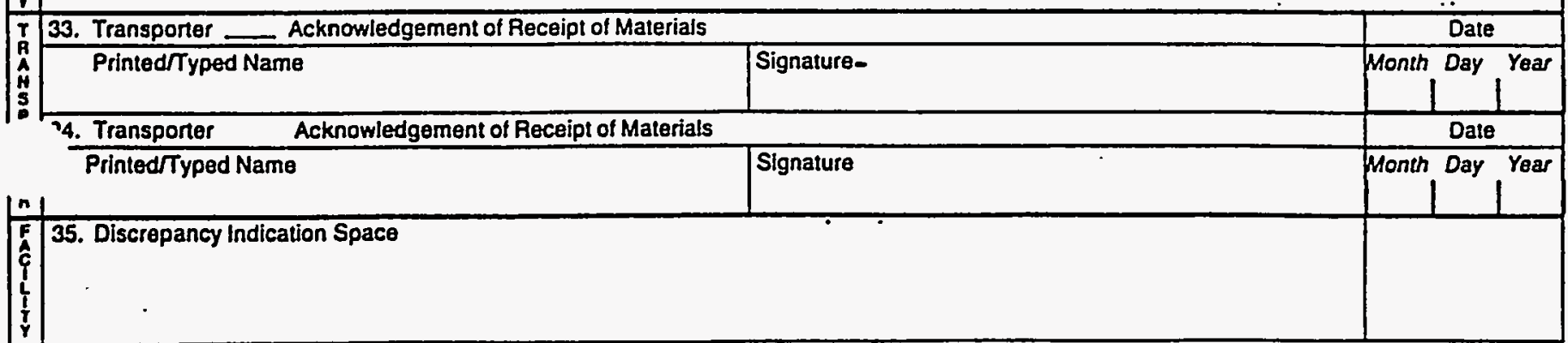


Please print or type. (Form designed for use on elite (12-pitch) typewriter.)

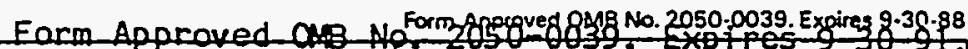

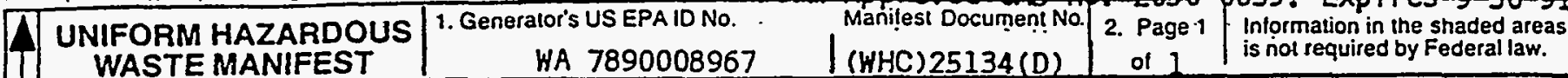

Generator's Name and Mailing Address DEPARTMENT OF ENERGY, RICHLAND OPERATIONS

P.0. BOX-550, 2401-STEVENS DR.,R2-82; RICHLAND; HA 99352

A. State Manifest Document Number: $: \because$ : $\therefore+4$ A Generator's Phone ( 509 . $373-4032(w) / 375-5491(h)$.. att: MR ROMSOS

5. Transporter 1 Companý Name $\cdot \cdots \cdot \cdots \cdot \cdots \cdot 6 . .^{-} \cdot \cdots$ US EPA ID Number $\cdot . \cdot$ RICHLAND POLICE/DOE-RL

7. Transporter 2 Company Name NONE

9. Desigialed Facility Narne and Site Address DEPARTMENT OF ENERGY, RICHLAND OPERATIONS P.O. BOX $550 ; 2401 \cdot$ STEVENS DR., RICHLAND, · HA 99352 CHEMICAL DETONATION PIT . . ...

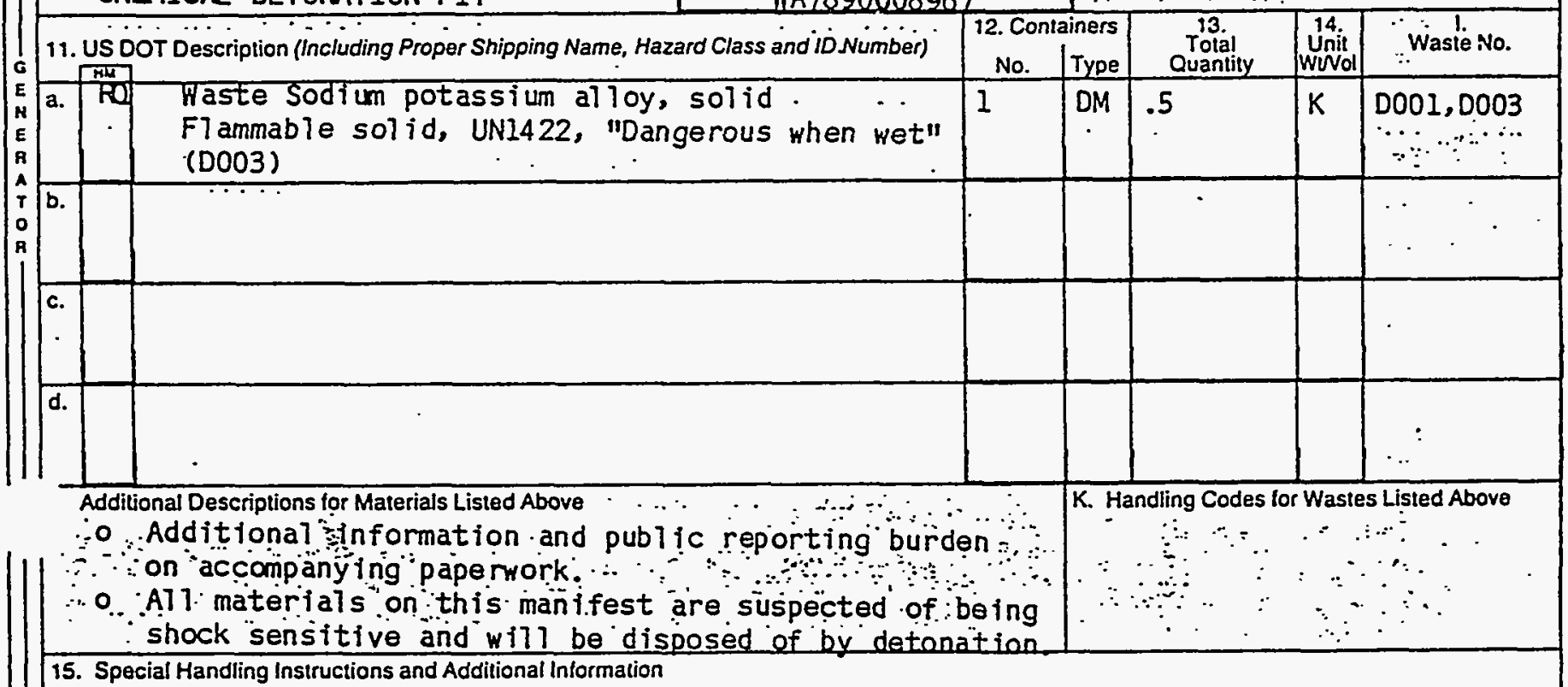

RETURN TO GENERATOR IF NOT DEI IVERED

16. GENEFATOR'S CEATIFICATION: I hareby dectare that the contenis of this consugnament are lutly and accurately desctibed above by proper shipging name and are classilied. packed. marked. and labeled. and are in all respects in proper condition lor transport by highway according to applicable international and national government regulations.

II I am a targe quantity generator, I cerrily that t have a program in place to recuce the volume and toxicity of waste generated to the degree I have determined to be economically practicable and that I have selected the practicable method of treatment, storage. or disposal curtently avaitable to me which minimizes the present and luture threal to human heallh and the environment; OR. il I am a small quantily generator, I have made a good faith ellort to minimize my waste generation and select the best waste management method that is avalable 10 me and that $t$ can akord. Printed/Typed Name ME BURNSIDE

Signature

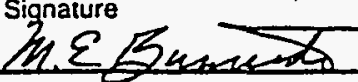
Monih Dar Year
$4|26| 89$

$T$ 17. Transporter 1 Acknowledgement of Receipt of Materials

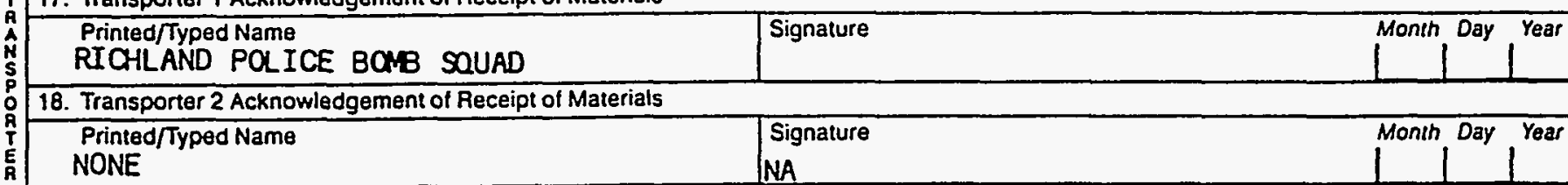

19. Discrepancy Indication Space $\mid \begin{aligned} & \mathbf{F} \\ & \mathbf{A}\end{aligned}$

:0. Facility Owner or Operator: Certification of receipt of hazardous materials covered by this manifest except as noted in llem 19.

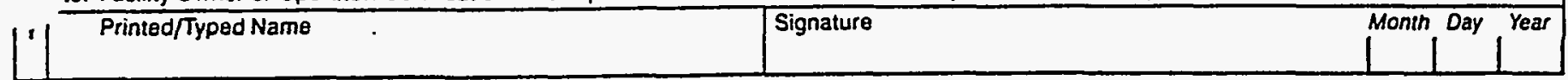

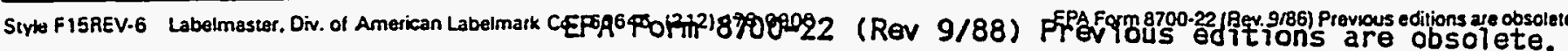


CHEIICAL YASTE DISPOSAL ANALYSIS NO. WHC-25-282

ISSUE DATE JUN 051989

\section{INSTE GEMERATOR}

Name D. J. Alexander

Address

Organization

Hestinghouse Hanford Company

Tel ephone

$373-2627$

Generator Logbook No.

N/A -

Accumulation

Date

April 24, 1989

Waste Shipment Deadline Date July 21, 1989

SITE HAZARDOUS WASTE ENGINEERING SUPPORT

2750E/A113/200 East (MSIN R1-51)

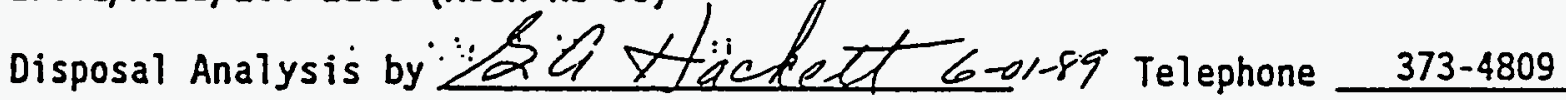

Approval (s)

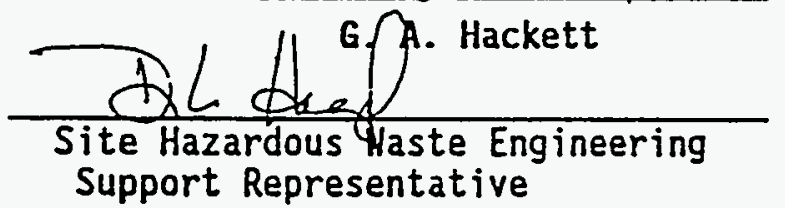

$\frac{\text { Duwh }}{\text { D. W. WiTson, Manager }}$ \&s Support Representative

INSPECTION: $\quad \begin{aligned} & \text { Inspection } \\ & \text { Representative } \frac{G \cdot 0 \cdot \cdot \text { Boness }}{376-7627}\end{aligned}$

NSPORTATIOH: SEE APPLICABLE FACILITY FOR TRANSPORTATION REPRESENTATIVE.

MASTE STORAGE/DISPOSAL DESTIMATION(S) [Check applicable facility(s)]

YX 616 Nonradioactive Dangerous Waste Storage Facility/616 Building/600 Area

212-P PCB Storage Facility

212-P Building/200 North Area

Facility

Representative. $373-3806$

Central Landfill Nonregulated Drum Storage Area/600 Area

XX Central Landfill Trash Trench/600 Area

XX Shock Sensitive/Reactive/Explosive Waste Disposal other: $:$ : other:

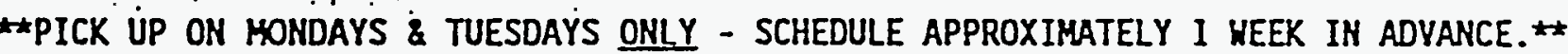

Transportation P. L. Hemsworth Representative $373-1881$

Transportation R. G. Dean

Representative $376-1420$

Transportation R. G. Dean Representative $376-1420$

Representative M. R. Romsos $373-4032$

\section{At.tachments}

S. M. Baker. (PCB Facility only)

G. O. Boness

J. E: Chulos (616 Facility only)

P. L. Hemsworth (616 Facility only)
D. E. Phelps (Central Landfill only)

H. R: Romsos : SHWES File 
DISPOSAL ANALYSIS NO. WHC-25-282

\section{EXPLOSIVE WASTE}

The following waste is determined to be explosive, and must be disposed of by contacting Mike Romsos on 3-4032.

\#22 Sodium Azide 1 100-g.glass jar (unopened) .1 K. 
DON'T SAY IT -.- Write It!

DATE June 19, 1989

TO M. R. Romsos

FROM G. A. Hackett

cC: SHWES File

SUBJECT: Chemical Waste Disposal Request No. HHC-25-282

Following is the information you requested on Sodium Azide:

Proper Shipping Name: Waste Sodium Azide (Land Ban: P105) Hazard Class: Poison B

I.D NO.: UN1687

Waste No's: P105, D003, WTO2 (EHW)

Label: Poison 


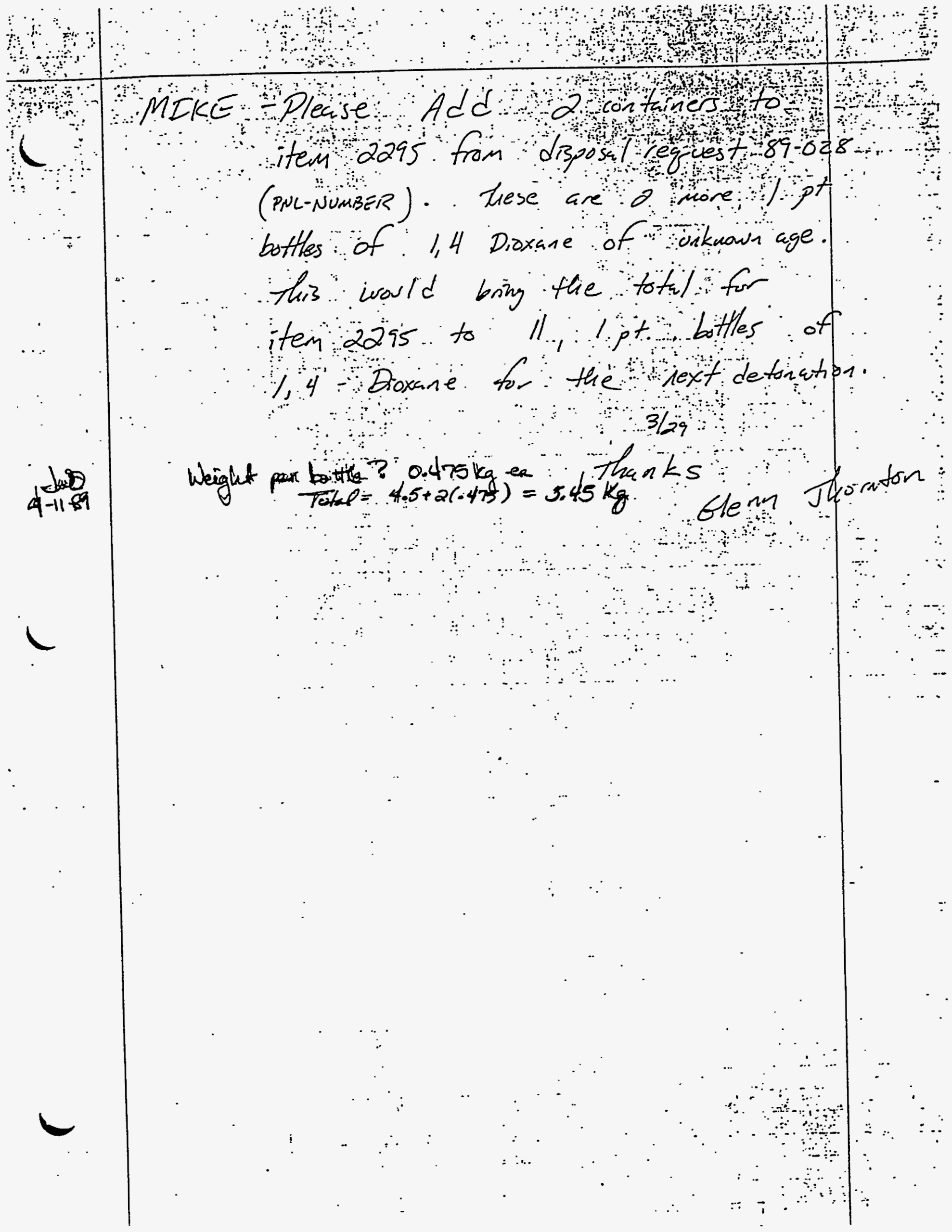


lease print or type. (Form designed tor use on elizo (12-pitch) typewriter.)

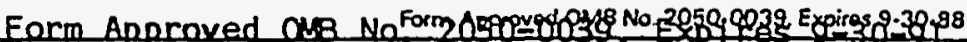

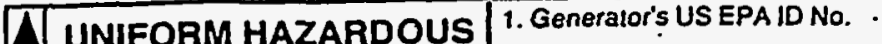

WASTE MANIFEST $\quad$ HA 7890008967 Manifest Document No.

Generalor's Name and Mailing Address

DEPARTMENT OF ENERGY, RICHLAND OPERATIONS

P. 0. BOX-550; 2401 - STEVENS DR, R2-82; RICHLAND, WA 99352

4. Generators Phone i 509 - ) 373-4032(w)/375-5491(h) . att: MR ROISOS

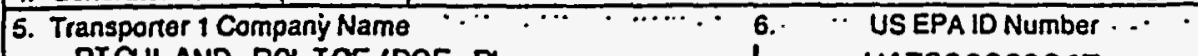

RICHLAND POLICE/DOE-RL $\quad$ WA7890008967

7. Transporter 2 Company Name * * . 8. US EPA IO Number

NONE

10. . USEPA LD Number

9. Designated Facility Name and Site:Address.
DEPARTMENT OF ENERGY. RICHLAND OPERATIONS

P.0. BOX.550, 2401-STEVENS DR.:RICHLAND; WA 99352

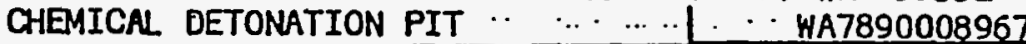

\begin{tabular}{|c|c|c|c|c|c|c|c|}
\hline \multicolumn{3}{|c|}{ 11. US DOT Description (Including Proper Shipping Name, Hazard Class and ID Number) } & \multicolumn{2}{|c|}{$\begin{array}{l}\text { 12. Containers } \\
\text { No. | Type }\end{array}$} & $\begin{array}{c}\text { T3. } \\
\text { Total } \\
\text { Quantity }\end{array}$ & $\begin{array}{c}\text { 14. } \\
\text { Unit } \\
\text { Wwol } \\
\end{array}$ & Wasto No. \\
\hline a. & $\mathrm{RO}$ & $\begin{array}{l}\text { WASTE FLAMMABLE LIQUID N.0.S. } \\
\text { UN1993 (nitrocel lulose) (D003) } \\
\ldots .\end{array}$ & 1 & $\mathrm{CF}$ & 4.075 & $K$ & 0001,0003 \\
\hline b. & Rol & $\begin{array}{l}\text { TASTE DIOXANE } \\
\text { FLAMMABLE LIOUID, UNII65 }\end{array}$ & 2 & CF & 6 & $K$ & 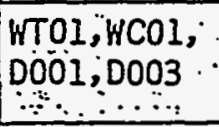 \\
\hline c. & Ral & $\begin{array}{l}\text { WASTE FLAMMABLE LIQUID, N. O.S. } \\
\text { UN1993 (D003). } \\
\ldots\end{array}$ & 1 & CF & 4.85 & K & $\begin{array}{l}\text { HTO2, D001, } \\
\mathrm{D003} \because \because \because \\
\therefore:\end{array}$ \\
\hline d. & $x$ & $\begin{array}{l}\text { WASTE TETRAHYOROFURAN } \\
\text { FLAMMABLE LIQUID, UN2056 } \\
.\end{array}$ & 2 & $C F$ & 7.8 & $k$ & $\begin{array}{l}\text { U213, WTO2, } \\
\text { D001 } \because \because \cdots\end{array}$ \\
\hline
\end{tabular}

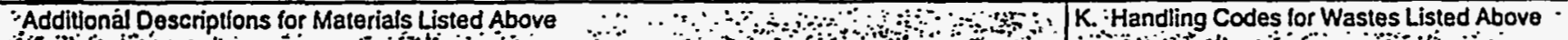

ato Adjtional Information and public reporting burden

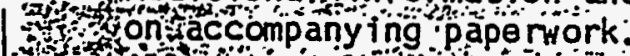

inot

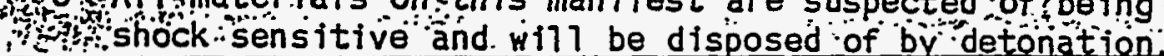

15. Special Handling Instructions and Additional Information

RETURN TO GENERATOR IF NOT DELIVERED

16. GEMERATOR'S CERTIFICATION: I hereby dectare that the contents of this consignment are fully and accurately described above by

proper shlpping name and are classilled, packed, marked, and labeled, and are in all respects in proper condition lor transport by highway

according to applicable international and natlonal government regulations.

II I am a lage quantily generator, I certily that I have a program in place lo reduce the volume and loxicity of wasto generated to the degree I have determined to be economically practicable and that t have selected the practicable method of treatment. storage, of disposal currently available to me which minimizes the present and fulure threat to human health and the envimonment: OR. il I an a small quantily generator, I have made a good laith ollort to minimize my waste generation and select the bost waste management method that is avaslable to me and that I can aflord.

Printed/Typed Name

GT THORNTON

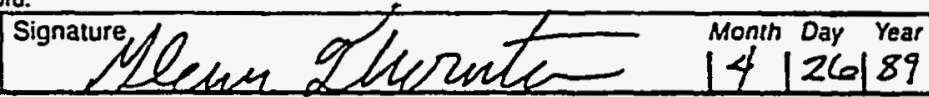

17. Transporter 1 Acknowledgement of Receipt of Materials

\begin{tabular}{|c|c|c|}
\hline $\begin{array}{l}\text { Printed/Typed Name } \\
\text { RICHLAND POLICE BOMB SOUAD }\end{array}$ & Signature & $\left.\left.\right|^{\text {Month Day }}\right|^{\text {Year }}$ \\
\hline \multicolumn{3}{|c|}{ 18. Transporter 2 Acknowledgement of Receipt of Materials } \\
\hline $\begin{array}{l}\text { Printed/Typed Name } \\
\text { NONE }\end{array}$ & $\begin{array}{l}\text { Signature } \\
\text { NA }\end{array}$ & Month Day Year \\
\hline
\end{tabular}

19. Discrepancy Indication Space

$\left|\begin{array}{l}\boldsymbol{F} \\ \mathbf{a}\end{array}\right|$

20. Facillty Owner or Operator: Certification of receipt of hazardous materials covered by this manilest except as noted in ltem 19.

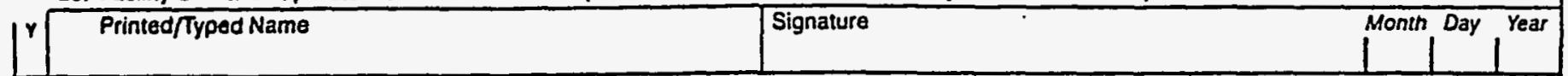

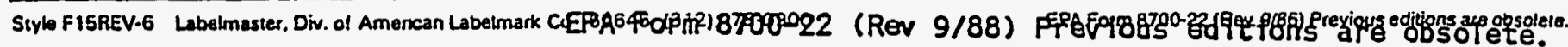




\section{TSD FACILITY UNMANIFESTED DANGEROUS WASTE REPORT}

Mail Original To:
STATE OF WASHINGTON
OEPARTMENT OF ECOLOGY
H.W. Section R/6 M/S PV-11
Olympia, WA $98504-8711^{\circ}$

\section{FORM 6}

DATE RECEIVED aY WCCE

\section{RECEIVING FACILITY INFORMATION}

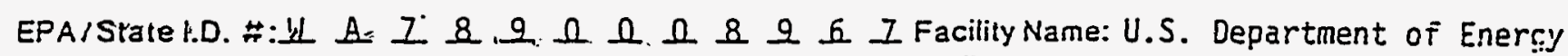

Facility Address (incl. City. State. Zip): 2401 Stevens Drive, Richland, WA 99352

Facility Contact Person: M R Romsos Phone Number: (509) 373-4032

\section{GENERATOR INFORMATION}

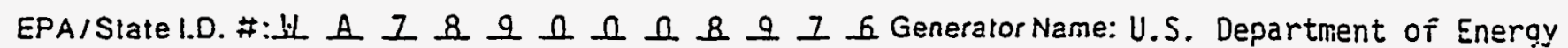
Generator Address (incl. City. State. Zip):2401 Stevens Drive, Richland, HA 99352

\section{TRANSPORTER INFORMATION}

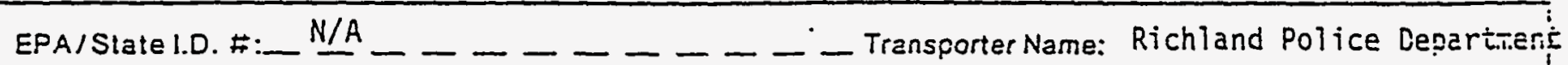

Transporter Address (incl. City. State. Zip): 505 Swift Blvd., Richland, WA 99352

Oriver's Name: J. L. Deyin

i. Vehicle License No: D29755 Driver's License No.: DELVIDL $4425 \mathrm{~N}$

IV. WASTE INFORMATION

A. Date This Wasie Shipment Received By Your Facility: $4 / 26 / 89$

B. Identification oi Waste(s)

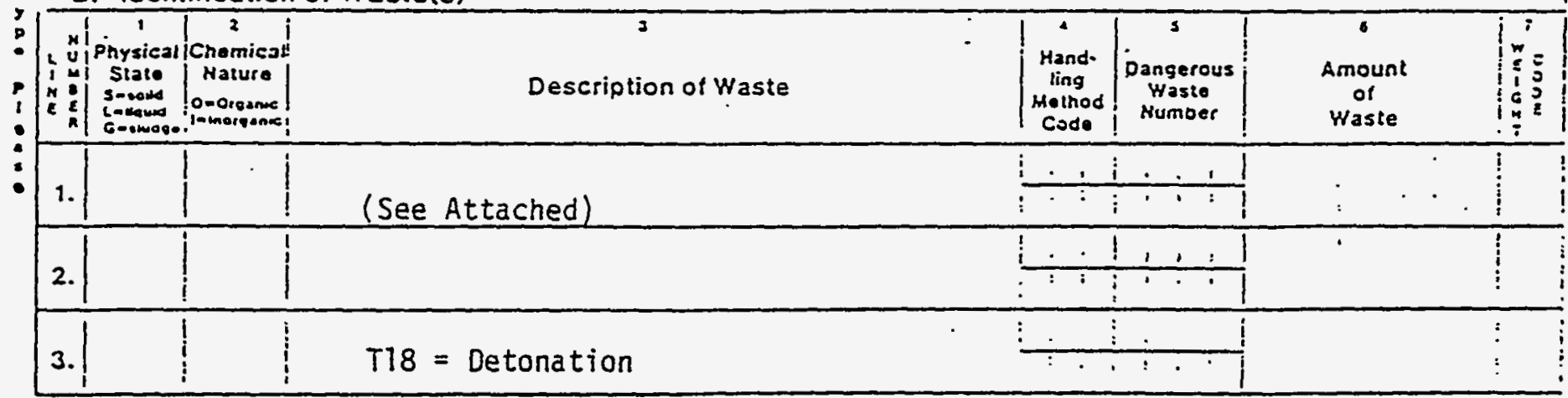

\section{COMMENTS}

Due to their age and method of storage, the chemicals described on this reportwere ceterminej (through process knowledge), to be reactive and potentially shock sensitive. For saiety reasons, the chemicals were transported in a trailer mounted bomb containment vessel to a Department of Energy-Richland Operations site permitted for this activity. The transiortation: vehicle was operated by the Richland Police Bomb Squad. Vehicle trafific during the transiar was controlled by site security personnel (transfer was performed during a low traitic tire period). Ambutance and Fire Department Units were present during the operations. ine bo-.j squad detonated the suspect chemicals using high explosives. The chemicals were not irom an off-site generator.

11. CERTIFICATION

$-$

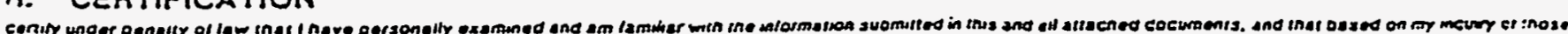

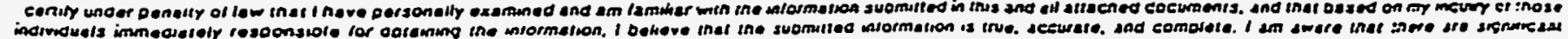

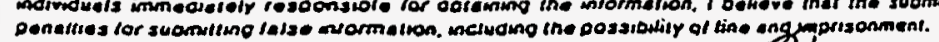

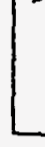

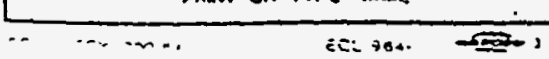$$
\text { MR Romrar }
$$$$
2
$$$$
\text { DRWT GA TrÁ VANE }
$$$$
9 / 21 / 89
$$ 


\section{ATTACHMENT 1}

\section{RECEIVING FACILITY INFORMATION}

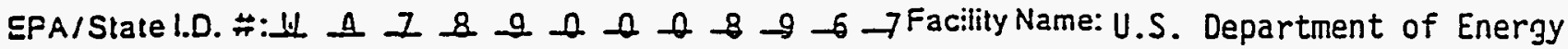
Facility Address (inc!. City, Slate, Zip): 2401 Stevens Drive, Richland, WA 99352

Facility Contact Person: M R Romsos

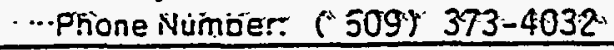

\section{GENERATOR INFORMATION}

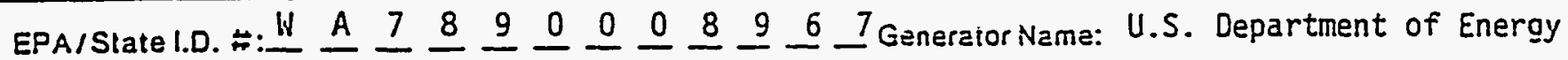
Generator Address (inc!. City. State. Zio): 2401 Stevens Drive, Richland, WA 99352

IV. WASTE INFORMATION

\begin{tabular}{|c|c|c|c|c|c|c|}
\hline \multicolumn{7}{|c|}{$\begin{array}{l}\text { A. Date This Waste Shipment Received By Your Facility: } \\
\text { B. Identification of } Y / a s i e(s)\end{array}$} \\
\hline 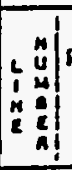 & 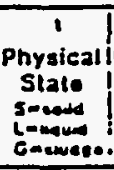 & 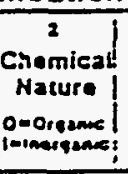 & Description of Waste & \begin{tabular}{|c|c|} 
& 1 \\
$\begin{array}{c}\text { Hand- } \\
\text { ling } \\
\text { Hethod } \\
\text { Coce }\end{array}$ & $\begin{array}{c}\text { Dangarous } \\
\text { Wasto } \\
\text { Cumoer }\end{array}$ \\
\end{tabular} & $\begin{array}{c} \\
\text { Amount } \\
\text { of } \\
\text { Waste }\end{array}$ & 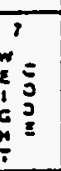 \\
\hline 1. & $S$ & 0 & Nitrocellulose (In iso-propyl alcohol) & 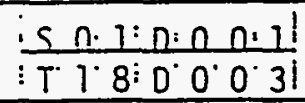 & $2.0 !$ & $k$ \\
\hline$\cdot 1$ & $L$ & 0 & Dibutyl Tetra Ethylene Glycol & $\frac{5 n \cdot 7 ! n \cdot 0 ! n: 3 !}{T 18: \div ! 1}$ & 2.0 & $k$ \\
\hline 3. & $\mathbf{L}$ & 0 & 2-: Methoxyethylether & 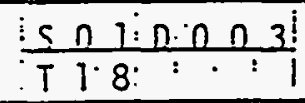 & $1.0 \vdots$ & $k$ \\
\hline 4.1 & S & 0 & 1,3,5-Trinitro Benzene & 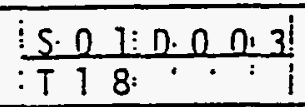 & 0.05 & 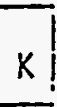 \\
\hline $5 . \mid$ & $L$ & 0 & 1,4-Diethoxybutane & 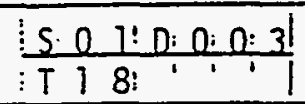 & $\begin{array}{c:c}\vdots \\
0.5\end{array}$ & $\mathrm{k}$ \\
\hline 6. & $\mathrm{~L}$ & 0 & 2-Ethoxybutanone & $\frac{50100 \Omega 3}{T 1 \cdot 8}$ & $0.1 \vdots$ & K \\
\hline 7. & $\mathbf{L}$ & 0 & Dimethoxypropane & $\frac{5 \cdot 0 \cdot 1 \div 0 \cdot 0.0 .31}{19}$ & $0.025:$ & \\
\hline 8.1 & $L$ & 0 & Di-tert-butyl-ether & $\frac{5 \cdot 0 \cdot 1: 0 \cdot 0 \cdot 0 \cdot 3 !}{T 18 !}$ & 0.025 & $k$ \\
\hline 9.1 & $S$ & 0 & Hexanitrodiphenylamine. & $\frac{5.0110003 !}{T 1 \cdot 8}$ & $0.025^{\vdots}$ & k \\
\hline ho. & $S$ & I & Anmonium Perchlorate & $\frac{5.0 .7: 0.003}{T 1.8}$ & $\begin{array}{r}\vdots \\
0.45\end{array}$ & $\mathrm{~K}$ \\
\hline 71.1 & $S$ & 0 & Benzoyl Peroxide & S. $019000 \%$ & $0.1:$ & $k$ \\
\hline . & L & 0 & n-Propylether & $\begin{array}{ccccccc}S & 0 & 1 & 0 & 0 & 0 & 1: \\
T & 1 & 8 & 0 & 0 & 0 & 3\end{array}$ & $0.5 \vdots$ & \\
\hline
\end{tabular}




\section{ATTACHAEMT 1}

$$
\left(\operatorname{con}^{\prime} t\right)
$$

RECEIVING FACILITY INFORMATION

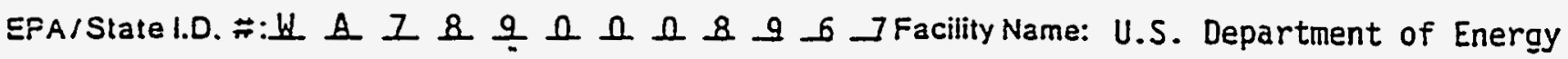
Facility Address (incl. City. Slate.Zip): 2401 Stevens Drive, Richland, WA 99352

Facility Contact Person: M.R Romsos Phone Number: ( 509) 373-4032.

GENERATOR INFORMATION

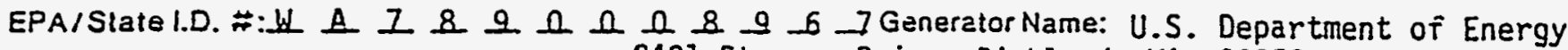
Generator Address (incl. City. State. Zio): 2401 Stevens Drive, Richland, WA 99352

IV. WASTE INFORMATION

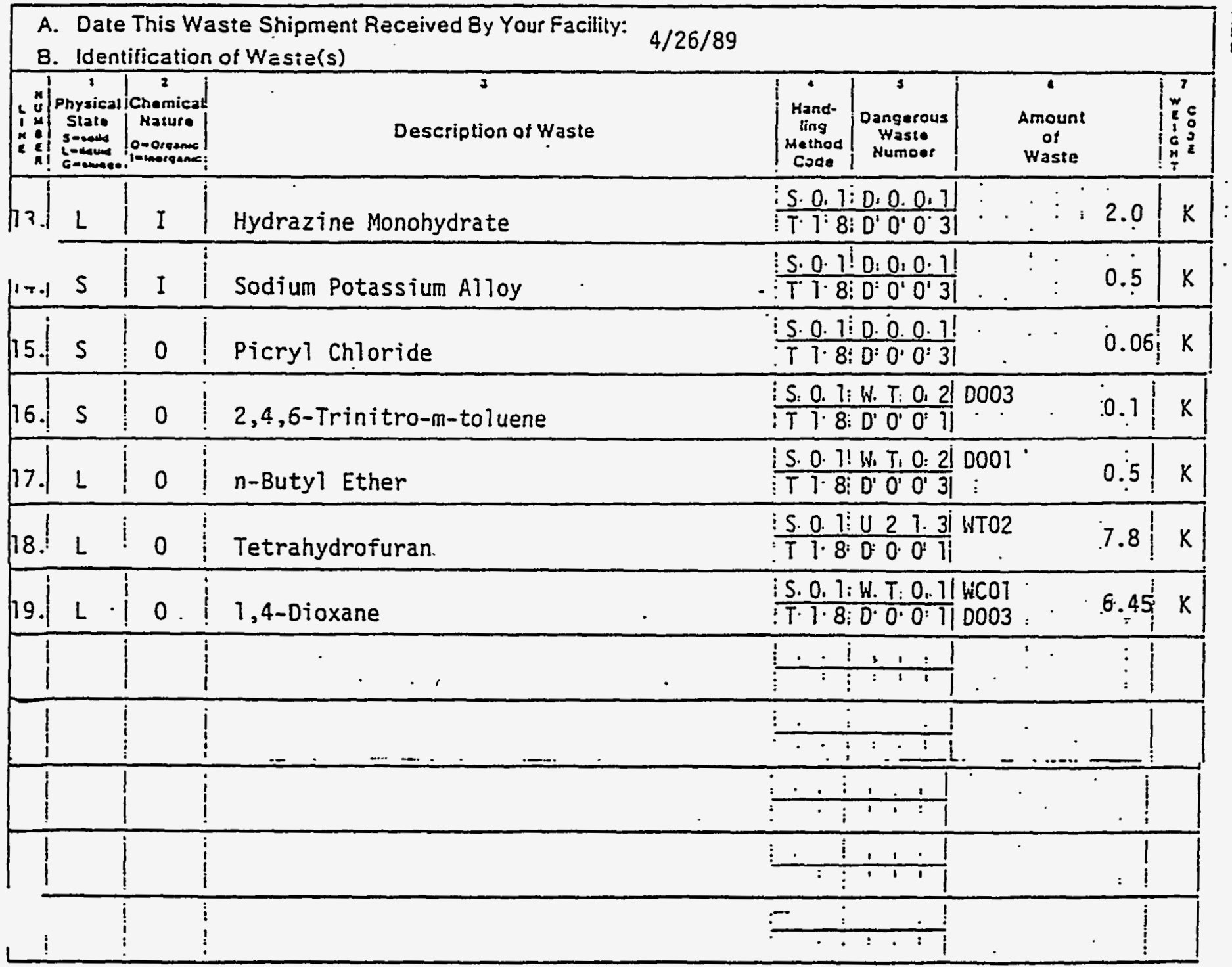


- Plesse print or type. (form designed for use on elite (12-pitch) typewriter.) .... .

$\cdots$

Form saprowd. ONB Na. 2050-00009. Expins 9-30-91

UNIFORM HAZARDOUS

WASTE MANIFEST

3. Generator's Name and Mailing Address

DEPARTMENT OF ENERGY, RICHLAND OPERATIONS

P.0. BOX-550; 2355-STEYENS DR;,R2-82; RICHLAND, HA 99352

4. Generators Phone ( $509 \cdots) \cdot 376-7688(\mathrm{~W})$ att: GT THORATION

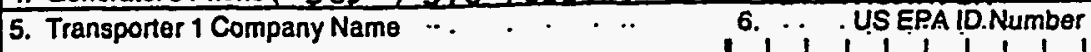
RICHLAND POL ICE BOMB SOUAD

7. Transporter 2 Company Name... NONE

9. Designated Facility Name and Site Address

HANFOFO PATROL ACADEMY DEMOLITION-SITE .... • .

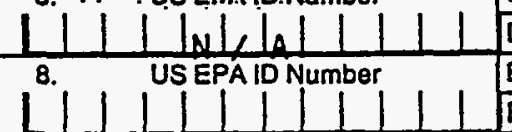

2. Page 1 Information in the shaded areas of 1 is not required by Federal law.

A: State Manifest Document Number

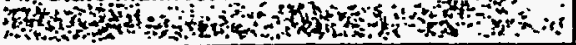
B. : Stale Generators 1D

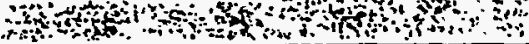

C... State Transporter's ID $\cdot \because, \cdots, \cdots$

D: Transporter's Phone:

E. State Transporter's if $943.9161^{\circ}$

F. Transporter's Phone $\because \because \because \cdot ;$

G. Slate Facility' ID $\because \cdots$ Hast

$\mathrm{H}:$ Facility's Phone $\mathrm{O}$,

11. US Dor Description (Including Proper Shipping Name, Hazárd Class and ID Nurriber)

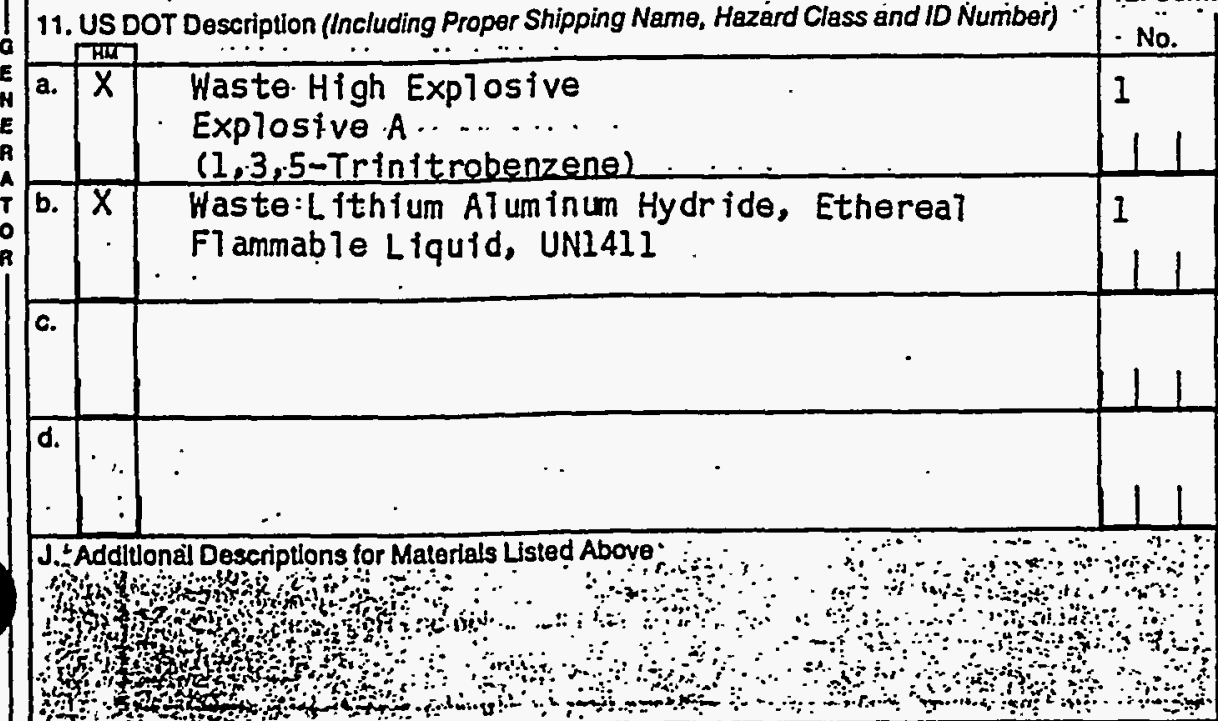

15. Spocial Handling Instructions and Additional Information

16. GEMERATOR'S CERTFFCATION: I hereby decture that the contents of thes consignment ara fully and accurately described above by proper entipping numo and ere clessefied, pected, marked. and labeled, and are in at respects in proper condition tor transport by lighway eccorting to apolcable inlemational and national governmant regulations.

If 1 em a large quantity generator, I cestry that I have a program in place to reduce the volume and boxicity of waste generated to the degree I have determined to be economically precticable and that I have selected the practlcable method of treatrnent, storage, or disposal currenuly available to me which minkmizes the present and

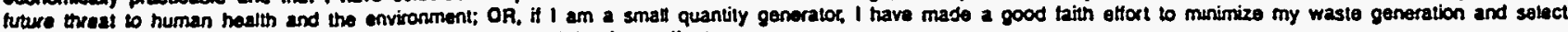
the best weste management method that $b$ availeble to me and that 1 can aftord.

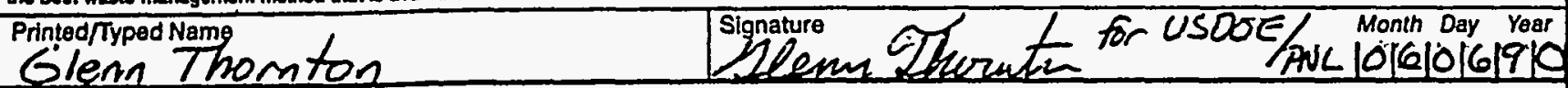

17. Transporter 1 Acknowledgement of Receipt of Materials \begin{tabular}{|l|l|l|}
\hline Printed/Typed Name & Signature Month Day Year \\
\hline
\end{tabular} NA

18. Transporter 2 Acknowledgement of Receipt of Materials Printed/Typod Name NA

K. Handling Codes for Wastes Listeg Above:

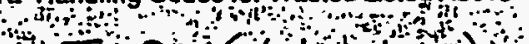
T 18 detonatión)

19. Discrepancy Indication Space

(F

20. Facility Owner or Operator: Certification of receipt of hazardous materials covered by thrs; 3 anifest except as noted in ltem 19. Printed/Typed Name

$M R$ Romsos

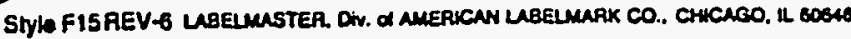

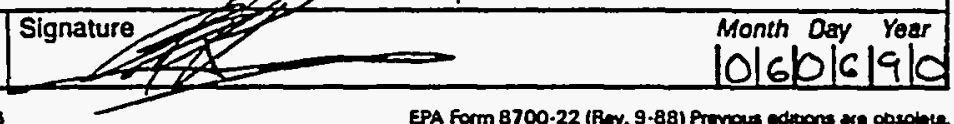

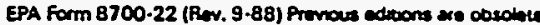




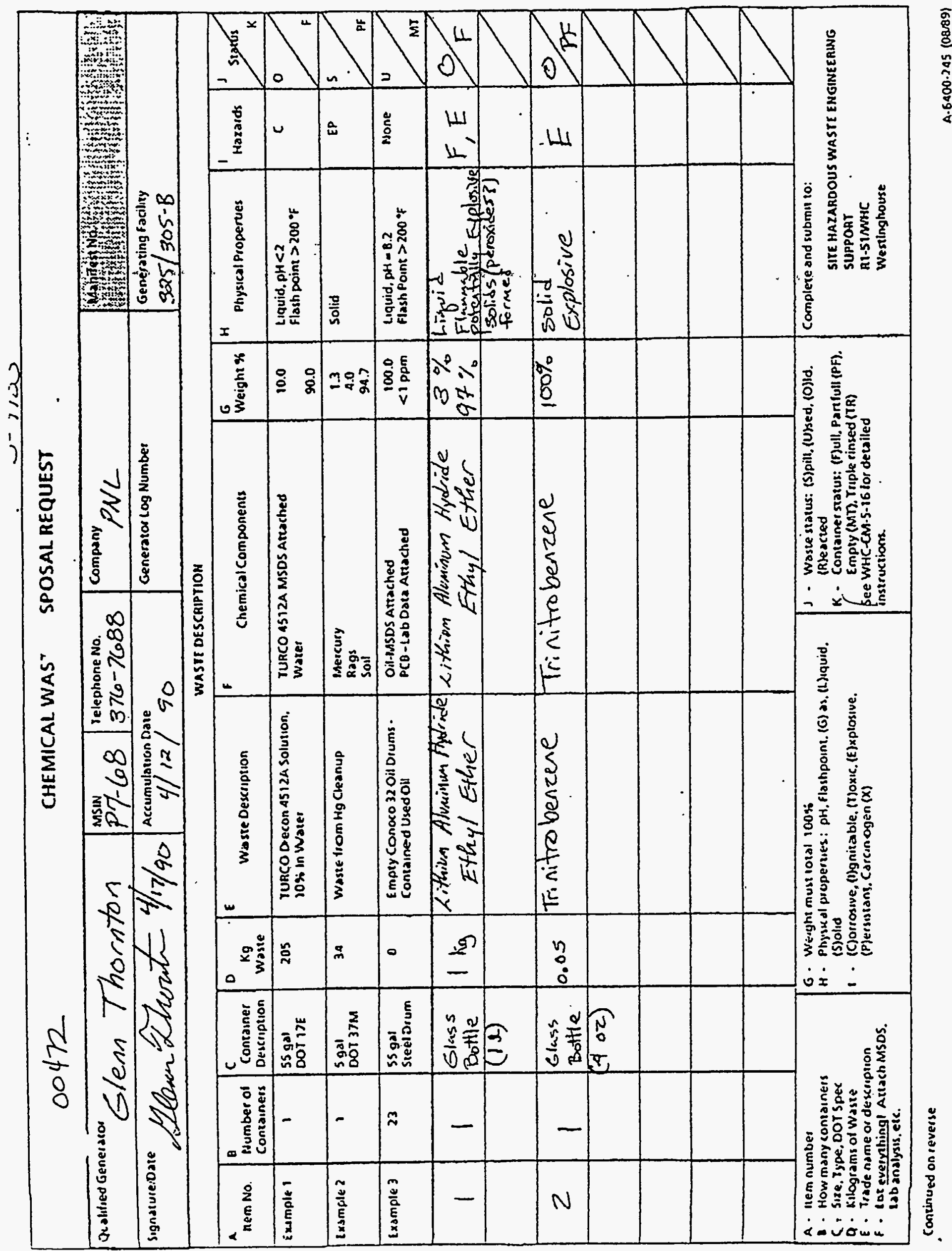


DISPOSAL ANALYSIS No. 10948 Gen. Log No. T-91-015

GENERATOR R. W. SZelmecZKa MSIN T3-28 PHONE $3-4329$ COMPANY HHC ACCUMULATION DATE 8/28/91 SHIPPING DEADLINE DATE 11/25/91 Analysis: Mandrake F. PascuaAMandrate 9.Puxenal Phone 376-4839 Review:
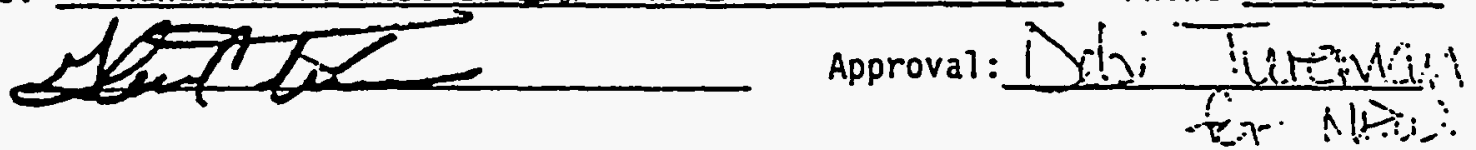

\section{GENERAL INSTRUCTIONS}

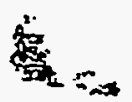

Package, Label, and Mark according to the Shipping Summary Table (attached). .

All shipping containers must be in good condition and tightly closed.

Container gross weight should be 450 pounds or less whenever possible.

Complete a Uniform Hazardous Waste Manifest. for shipments of requlated waste.

All regulated waste must be inspected by Transportation Logistics (376-7627) Obtain radiological release or exemption within 24 hours before transport. Arrange for transport at least one week ahead of time.

SEE WHC-CM-5-16 AND WHC-CM-2-14 FOR DETAILS OF PACKAGING AND SHIPPING

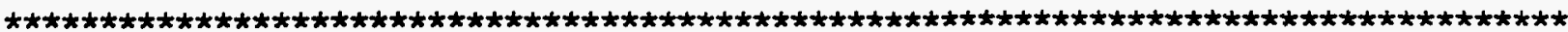

Waste Destination

X 616 Nonradioactive Haste Storage _212-P PCB Storage 200 North Non-regulated Drum Storage.

X_Central Landfill Trash Trench

X_other: Item \#32
Transportation Rep.

R. Pedraza

P. C. Hendrix

P. C. Hendrix

P. C. Hendrix

M. R. Rọsos
Phone Number -

373-1881

376-0971

376-0971

$376-0971$

$376-4900$

cc: Solid Waste Engineering Analysis, others as needed:
M. A. Sams
G2-03
J. H. Pratt T4-01
D. L. Barron
$\$ 2-62$
R. Pedraza T3-21
M. R. Romsos
N3-11
Central Landfill operator G4-07 
MANIFEST NO: 10948

ITEM NUMBER: 42

SHIPPING NAME: Non-RCRA waste, liquid (continued)

HASTE CONTENT: Dow Corning (R) DB-110A Anti Foam Emulsion; 95\% polyethylene glycol, $10 \%$ silicon fluid :

QUANTITY: $\quad$ (1) glass bottle weighing $0.5 \mathrm{~kg}$

WASTE NUMBERS: WTO2, (DW)

\section{ITEM"NUMBER:' 52}

WASTE CONTENT: 100\% sodium iodide

QUANTITY:

(10) glass \& plastic containers weighing $1.5 \mathrm{Kg}$

WASTE NUMBERS: WTO2. (DW)

\section{ITEM NUMBER: $45 \& 46$ SHIPPING NAME: Waste Sodium dichromate}

HASTE CONTENT: $100 \%$ sodium dichromate. (Land Ban: DOOT)
HAZARD CLASS: ORM-A

DOT ID NO: NAI479

DOT LABEL: Hazardous waste

PACKAGING: $\quad$ Per 49 CFR 173.505

QUANTITY: $\quad$ (1) glass bottle \& (1) plastic bottle weighing a total of $0.9 \mathrm{~kg}$

HASTE NUMBERS: D007, D002, WCO1, WTO2, (EHW).

SHIP TO:

616 building

CELL: 0

ITEM NUMBER: 49 SHIPPING NAME: Hazardous waste, solid, N.0.S.

WASTE CONTENT: $99 \%$ barium carbonate. (Land Ban: D005)

HAZARD CLASS: ORM-E

DOT ID NO: NA9189 (barium carbonate)

DOT LABEL: Hazardous waste

PACKAGING: $\quad$ Per 49 CFR 173.1300

QUANTITY: $\quad$ (1) glass bottle weighing $0.1 \mathrm{~kg}$

WASTE NUMBERS: D005, WTO2, (EHW)

SHIP TO: $\quad 616$ building

CELL: Anv. except 0

ITEM NUMBER: 32 (Hydroxylamine hydrochloride,crystal)

* This material can react violently with shock, friction, or heat according to the Materiat Safety Data Sheet.

* Please contact Mike R. Romsos at 376-4900 for disposal of this waste.

The following waste is not regulated according to WAC 173-303 and 40 CFR 261 .

Item no. 7: (1) steel can weighing $0.5 \mathrm{~kg}$ that contains $100 \%$ aluminum hydroxide.

Item no. 8: (4) poly bottles weighing $0.25 \mathrm{~kg}$ that contains DOW Corning Polystyrene Latex UPSL.

Item no. 17: (1) plastic bottle weighing $0.5 \mathrm{~kg}$ that contains $100 \%$ ferric oxide.

Item no. 18: (1) plastic bottle weighing $0.5 \mathrm{~kg}$ that contains 98-100\% calcium chloride, dihydrate. 
APPENDIX 5A“

GROUNDWATER DATA FOR THE HANFORD PATROL ACADEMY DENOLITION SITES 


\section{CONTENTS}

5A.0 GROUNDWATER DATA FOR THE HANFORD PATROL ACADEMY

DEMOLITION SITES ........................... 5A-1

5A.1 EXISTING GROUNDWATER WELLS ................. 5 . 5 A-1

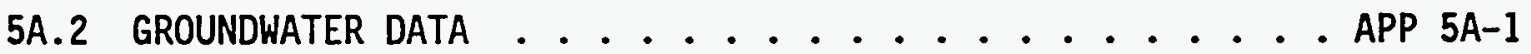

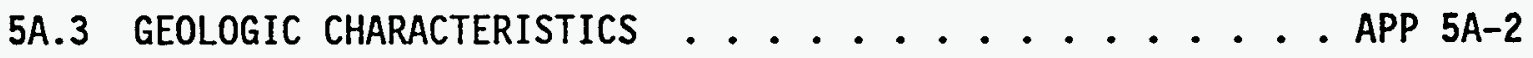

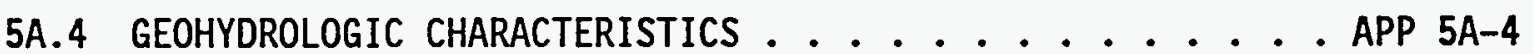

5 5.5 POTENTIAL MIGRATION ...................... 5 . 5 . 5

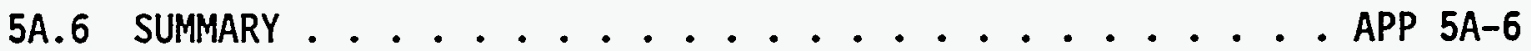

\section{FIGURES}

5A-1. Well Locations .......... APP 5A-F1

5A-2. Well Summary for 6-531-1 and 6-531-iP ......... APP 5A-F2

$5 A-3$. Well Summary for $6-528-E 0 \ldots \ldots$. . . . . . . . APP 5A-F3

5A-4. Hydrographs for We17s 6-531-1 and 6-531-1P ....... APP 5A-F4

5A-5. Water Quality Data ............. APP 5A-F5

5A-6. Water Table Map ............... APP 5A-F6

5A-7. 100-Year Flood Event . . . . . . . . . . APP 5A-F7 


\section{A.0 GROUNDWATER DATA FOR THE HANFORD PATROL ACADEMY DEMOLITION SITES}

Two groundwater wells are located in the general vicinity of the HPADS; one of these wells consists of two completions at a single location (Figure 5A-1). These wells currently are being used by the Hanford Sitewide environmental surveillance program, which is conducted by Pacific Northwest Laboratory under DOE Order 5400.1. The wells were constructed before RCRA we.17 standards. The well construction characteristics are shown in. Figures $5 A-2$ and $5 A-3$. The well descriptions are from the original driller's logs; no geologist logs are available.

\section{A. 1 EXISTING GROUNDWATER WELLS}

Well 699-S31-1 is located approximately 1 mile (1.6 kilometer) south of the HPADS. The well is roughly up- (groundwater flow) gradient and is completed to monitor the uppermost confined aquifer. The well was drilled in 1951 to a total depth of 228 feet (69.5 meters) where it bottomed in basalt. The well is perforated between 93 and 103 feet (28.3 and 31.4 meters). While drilling, groundwater from several hydrologic units were apparently encountered. A second, 4-inch (10.2-centimeter) casing was installed inside the larger casing, and a cement seal placed between 142 and 177 feet ( 43.3 and 53.9 meters), in an attempt to isolate groundwater from different strata. The unperforated 4-inch (10.2-centimeter) casing is probably the well 1abeled 699-S31-1P. The well appears to monitor confined conditions near the base of the Ringold Formation, or possibly a flow top in the uppermost basalt strata.

Well 699-S28-EO (E "zero") is located approximately 0.75 mile (1.2 kilometer) east of the HPADS. The we17 is downgradient and is completed in the unconfined aquifer, with perforations between 90 and 180 feet $(27.4$ and 54.9 meters). The well was drilled in 1981 as a 'sanitary water we11' ' and bottomed in basalt at 236 feet ( 71.9 meters). A bentonite surface seal was installed.

In the following sections, the 699-prefix is omitted from the well. numbers for brevity.

\section{A.2 GROUNDWATER DATA}

Groundwater quality data and hydraulic head data described in the following paragraphs for the two well locations are taken from the operating contractor's Geosciences Group Paradox* database. This database in an outgrowth of the former Hanford Groundwater Data Base, and fills an interim need for a groundwater data management system while the Hanford Environmental Information System (HEIS) is being developed. The data presented should be used for informational purposes only. 
Hydrographs for S31-1 and S31-1P are shown in Figure 5A-4. The change in trends that occur in the late 1970's might be related to the removal of piezometers, as indicated on a subsequent driller's $10 \mathrm{~g}$ for that well. No water level data are available for S28-E0. Water levels currently are being measured routinely in $531-1$.

Water quality data for each of the three wells are tabulated in Figure 5A-5. Drinking water standards for selected constituents also are shown. When a 'Tess-than' flag (<) appears after the sample date, this indicates the results are below the detection limit, which is shown in the analysis value column. For some results, the current detection limit shown is lower than the detection limit in place at the time of analysis. None of the wells currently contain water samples that exceed drinking water standards (40 CFR 265.92). While some radionuclide activity is measurable, no activity exceeds drinking water standards. Currently, all samples were below maximum contaminant levels.

Currently available groundwater data are insufficient to fully evaluate the potential for groundwater contamination as a result of HPADS operations. However, given the nature of operations and the absence of appreciable liquid waste disposal, none is expected.

\section{A.3 GEOLOGIC CHARACTERISTICS}

The HPADS is located approximately 2.4 miles $(3.9$ kilometers) west of the Horn Rapids Landfill entrance. It is situated at an elevation of approximately 452 feet (137.8 meters) above mean sea leve1, between the Yakima and Columbia Rivers, which are at elevations of approximately 370 feet (172.8 meters) and 340 feet (103.6 meters), respectively. The 1 and surface slopes generaliy to the southwest toward the Yakima River and to the east toward the Columbia River. Longitudinal dunes in the HPADS area trend southwest-to-northeast and are on the order of 10 feet $(3.0$ meters). The dunes are locally active, but for the most part, the dunes have been stabilized by vegetation or have been reworked as a result of grading and excavation for onsite activities.

The principal structural feature is the Pasco Basin, which is one of several sediment-filled basins in the Central Columbia Plateau. The sediments in the Pasco Basin, as well as of the entire Columbia PFateau, are underlain by the Miocene age Columbia River Basalt Group. The sediments overlying the basalts, from the basalts upward, include (1) the Ringold Formation; (2) glaciofluvial deposits of the Hanford formation, which include Pasco gravels and touchet beds; and (3) surficial eolian sediments and basalts.

Ringold Formation. This formation in the Pasco Basin ranges in age from 8.5 to 3.9 million years before present (DOE-RL 1988a). The Ringold Formation directly overlies the uppermost basalt flows of the Columbia River Basalt Group. The Ringold Formation is a fluvial sedimentary unit that exhibits lateral facies variations. Major facies of the Ringold Formation include the main river channel facies, overbank facies, and fanglomerate facies. Because 
of facies variations and limited data, the stratigraphic relationship between Ringold units observed in the 3000,300 , and 1100 Areas, and we11-studied sections in the western Pasco Basin, is not completely known.

Newcomb (1958) divided the Ringold Formation into three members, based on exposures at the type section along the southern end of the White Bluffs (located along the Columbia River on the east side of the Hanford Site). These are a "lower blue clay.member", a "middle conglomerate member", and an "upper member". The "lower blue clay member" (now called the lower Ringold unit) is known to overli.e a thin basal Ringold unit composed of clayey, to gravelly sand. The lower unit is generally a clay or silt that. often contains sandy or gravelly layers (Newcomb et al. 1972). The middle Ringold unit is generally a sandy gravel, with local sand or silt lenses. The upper Ringold unit, found mainly in the White Bluffs area to the north and across the Columbia River from the 300 Area, is composed mainly of fine sand and silt.

Hanford Formation. Overlying the Ringold Formation are mostly coarsegrained deposits, belonging to the Hanford formation. The Hanford formation is composed of deposits derived from the sudden release of Pleistocene-age ice-dammed lakes located north and east of the Columbia Plateau. The earliest floods occurred less than 800,000 years before present (Bjornstad et al. 1987 ); the last flood occurred approximately 13,000 years before present (Mullineaux 1986). Within the Pasco Basin, these floods incised into and stripped away much of the Ringold Formation.

Flood gravels consist of very coarse, sandy, cobble-boulder gravel within and adjacent to the main flood channels. Elsewhere, in areas marginal to flood channels, such as the western portion of the 300 Area, it appears that finer grained deposits consisting of pebbly gravels and sand were deposited.

The boundary between the Ringold and Hanford formations under the HPADS appears to be gradational, both in lithologic as well as hydrologic properties. In general, flood gravels of the Hanford formation can be differentiated from coarse-grained Ringold deposits by (1) less consolidation, (2) less alteration, (3) poorer sorting, and (4) higher percentages of angular basalt clasts. However, the contact is indistinct where flood gravels overlie coarse-grained Ringold facies, because sediment transported along the bases of flood channels consisted of mostly reworked deposits of the easily erodible Ringold Formation. Based on borehole cuttings alone, it is extremely difficult to differentiate between reworked and intact portions of the. Ringold Formation.

Eolian Deposits. Overlying the Hanford Formation within the HPADS is a thin veneer of fine- to coarse-grained eolian sand deposits. The thickness of this unit is quite varied, ranging from 0 to 15 feet ( 0 to 4.6 meters). Eolian sand generally is lacking in areas where the surface has been disturbed by man. The contact between the eolian deposits and the Hanford Formation is well defined.

Geologic data obtained from the driller's logs for wells S31-1 and S28-E0 are limited. At the time the wells were drilled, general lithologic data were recorded by the driller and not by a trained geologist. Therefore, 
lithologic information is ambiguous. Because of the relative location of the HPADS to the 1100 and 300 Areas, it is reasonable to assume that the HPADS have similar hydrogeologic and geologic features.

\section{A.4 GEOHYDROLOGIC CHARACTERISTICS}

Groundwater beneath the area around the HPADS occurs in confined aquifers within the basalt sequence and lower Ringold, the unconfined aquifer of the Pasco gravels, and the sands and gravels. of the Ringold. Formation. The boundary between the confined and unconfined aquifers is typically the lowermost silt and clay member of the Ringold Formation (Lindberg and Bond 1979). A confined aquifer might exist in gravel layers beneath this silt/clay member, immediately above the basalt. The depth to the water table in the vicinity of the HPADS is approximately 85 feet (25.9 meters). Because of lateral facies variation, silt or clay lenses in the Ringold Formation might function as aquitards on a local scale. Perched or semiperched water conditions also might occur locally.

The unconfined aquifer in the area exhibits relatively high permeability, particularly in the Pasco gravels. Aquifer pumping test and numerical groundwater modeling for the 300 Area indicate transmissivities greater than 100,000 square feet $(9,290$ square meters) per day (Lindberg and Bond 1979). The storativity of the unconfined aquifer has been-estimated at 0.1 in hydrologic studies of the 300 Area (Lindberg and Bond 1979). Aquifer tests conducted in the north Richland well field (ICF 1987) indicate a transmissivity of 86,000 square feet $(7,989$ square meters) per day, and storativity of 0.11 . No measurements of these parameters other than hydraulic properties of the aquifers beneath the HPADS are available. However, available data suggest that hydrologic properties of the HPADS might be similar to those of the 1100 Area.

Water table maps for the Hanford Site indicate that within the vicinity of the HPADS, the water table dips east-northeast and ranges in elevation from 370 to 375 feet (112.8 to 114.3 meters) above mean sea level (Figure 5A-6). Regional groundwater flow in the HPADS is thought to be generally west to east, and controlled by the elevation difference between the Yakima and Columbia Rivers. The Yakima River is recharging the unconfined aquifer, which in turn discharges to the Columbia River. There are a number of factors that might complicate this relatively simple description:

- Spatial differences in hydraulic conductivity of the unconfined aquifer

- The river stage of both the Yakima and Columbia Rivers

- Infiltration to the unconfined aquifer from irrigation

- Upward leakage (discharge) from the confined aquifer to the lower part of the unconfined aquifer 
- A water table that sometimes lies within the higher permeability Pasco gravels and in other areas within the lower permeability Ringold Formation.

Given the heterogeneity of both the Pasco gravels and the Ringold Formation, together with the various recharge/discharge points and seasonal variations in withdrawal, the groundwater flow conditions in the HPADS closure areas are likely to be complex, and direction and rate of groundwater flow are likely to change with time.

\section{A.5 POTENTIAL MIGRATION}

No soil data currently exist (beyond Appendix $3 A$ ) to establish whether. or not mobile residues from demolition events are present. Transport of potential residues might occur by (1) infiltration of precipitation, (2) extreme floods of the Yakima and Columbia Rivers, (3) or unreported liquid waste disposal.

Precipitation for the Hanford Site is measured at the Hanford Meteorological Station. The average annual precipitation at the Hanford Meteorological Station is 6.3 inches (16 centimeters). The total annual precipitation ranges (98 percentile) from 3.15 to 11 inches ( 8 to 28 centimeters). Most of the precipitation takes place during the winter, with nearly half of the annual amount occurring in the months of November through February. Days with greater than 0.5 inch ( 1.3 centimeter) of precipitation occur less than 1 percent of the year. Rainfall intensities of 1 inch (2.54 centimeter) for 1 hour are expected only once every 500 years. Winter monthly average snowfall ranges from 0.3 inch ( 0.8 centimeter) in March to 5.3 inches (13.5 centimeters) in January. The record snowfall of 24.4 inches (62 centimeters) occurred in February 1916, but the second highest snowfall is less than half this amount (DOE 1987). To date, the very small amount of precipitation in the region has not been proven to be capable of driving contaminants to the water table.

Average annual pan evaporation exceeds 60 inches (152.4 centimeters). Average annual lake evaporation ranges from 39 to 41 inches $(99.1$ to 104.1 centimeters). Actual evapotranspiration is essentially equivalent to annual precipitation (Leonhart 1979). Because potential evapotranspiration greatly exceeds significant annual precipitation, it is uni ikely that precipitation promotes movement of contaminants to groundwater. For further information on the current state of knowledge regarding infiltration of precipitation on the Hanford Site, refer to Rockhold et al. (1990) and Smoot et al. (1989).

The 100-year flood event is another possible mechanism for transport of mobile residues. Figure 5A-7 shows the highest floods on record and probable maximum floods. During probable maximum flooding, the HPADS closure areas would not be inundated by floodwaters. Thus, flooding would not affect the HPADS (Figure 5A-7). 
As described in the closure plan, there is no recollection of any liquid waste disposal within the closure sites. The only known item that is buried at the site is a 5-galion (18.9-1iter) container of napalm-B, which did not detonate after numerous ignitions. The container was buried somewhere nearby the HPADS and according to the closure plan, ground-penetrating radar will. be used to locate the buried container. The 1100-EM-1 Operable Unit work plan contains CERCLA information about the Hanford Patrol Academy area (DOE-RL 1988a).

\section{A.6 SUMMARY}

Existing groundwater data provide very limited information concerning possible groundwater contamination within the area of the closure sites. Two wells located near the closure sites are not directly within the apparent flow path under the closure sites, and therefore, are not the best indicators for closure area groundwater contaminants.

Process knowledge, as described in the closure plan, indicates no free liquids have been released to the soil in the closure areas, thus reducing the likelihood of contaminants with in the groundwater. The 5-gallon (18.9-1iter) canister of napalm-B buried in the relative proximity of the closure areas has little likelihood of impacting groundwater.

The available groundwater data do not suggest contamination attributable to the HPADS. The description of activities at the HPADS also suggests a low potential for contamination of the uppermost aquifer. The results of planned soil sampling activities, as described in the closure plan, will help to evaluate the potential for groundwater contamination. 


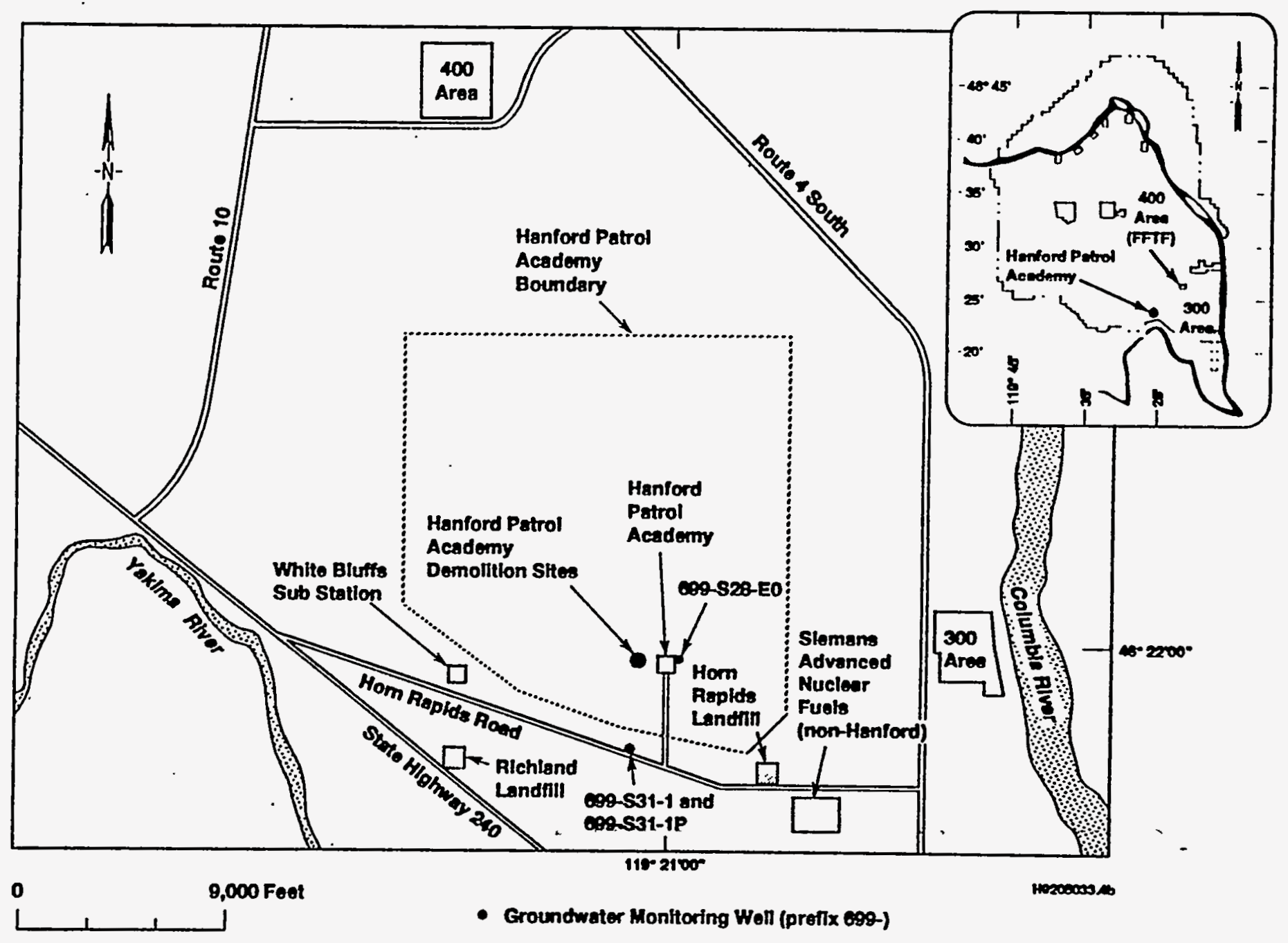

Figure 5A-1. We11 Locations. 


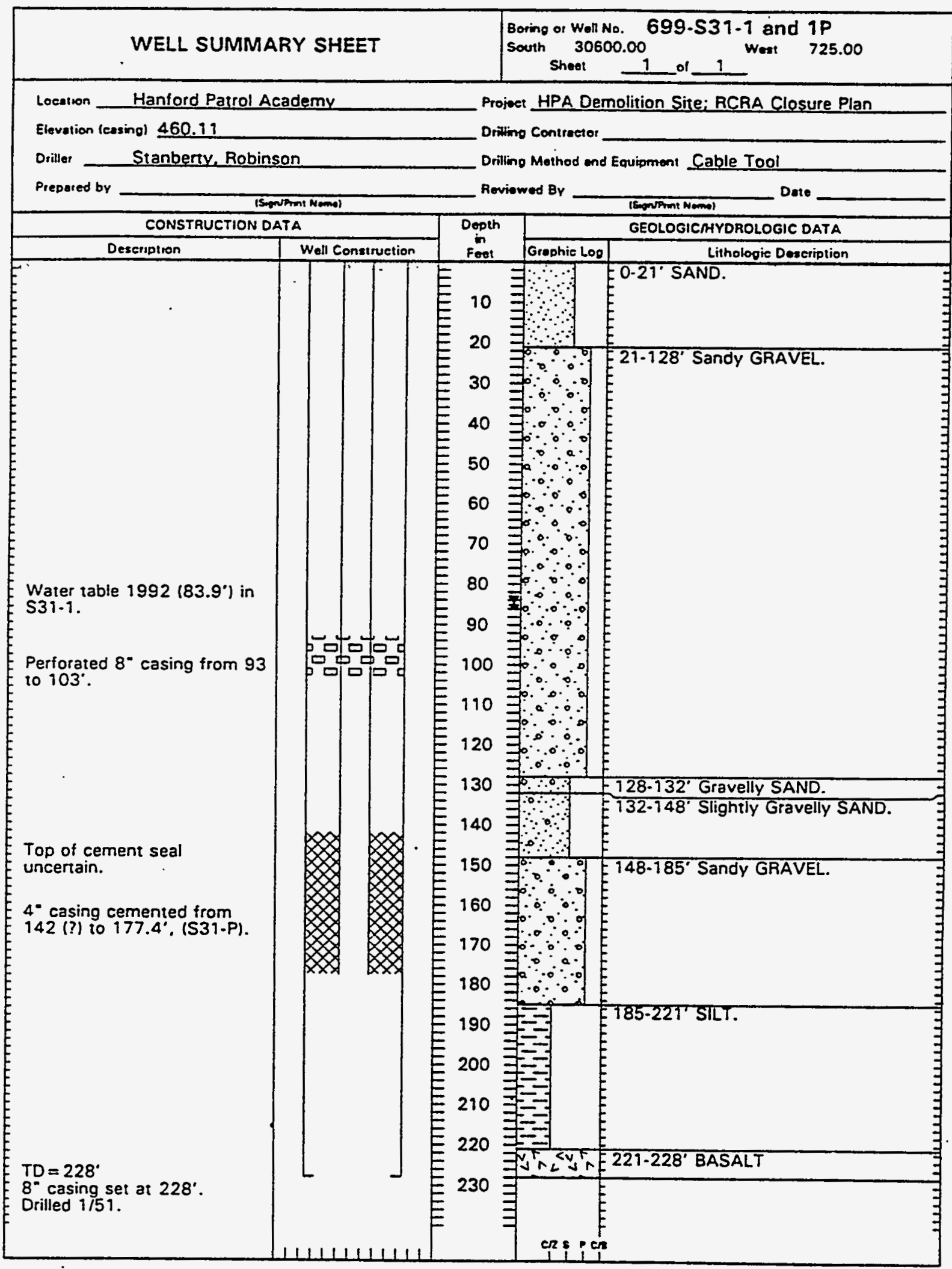

Figure 5A-2. We11 Summary for 6-531-1 and 6-531-1P. 


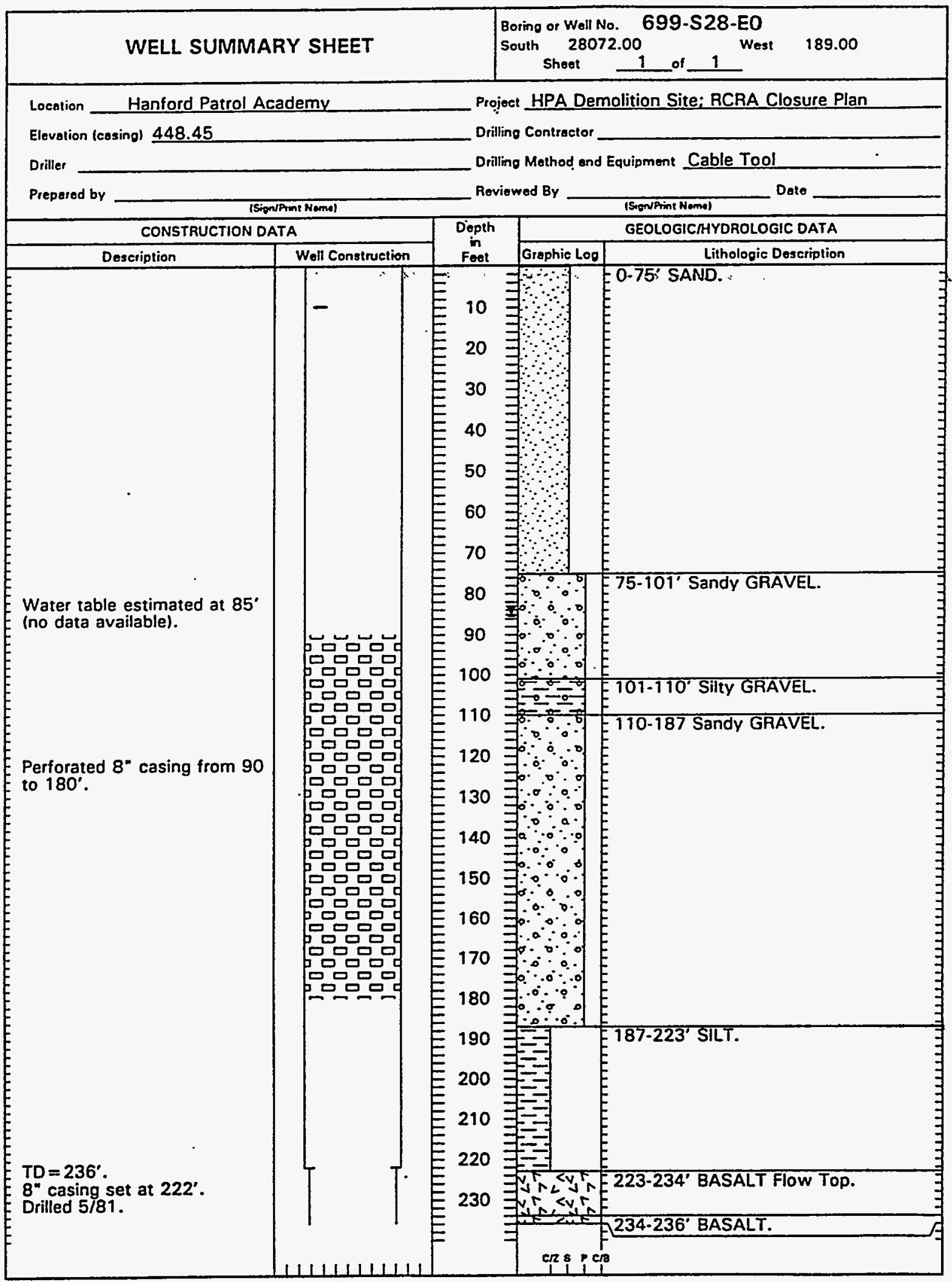

Figure 5A-3. Well Summary for 6-528-EO. 
D0E/RL-92-39, Rev. 1

$12 / 15 / 94$

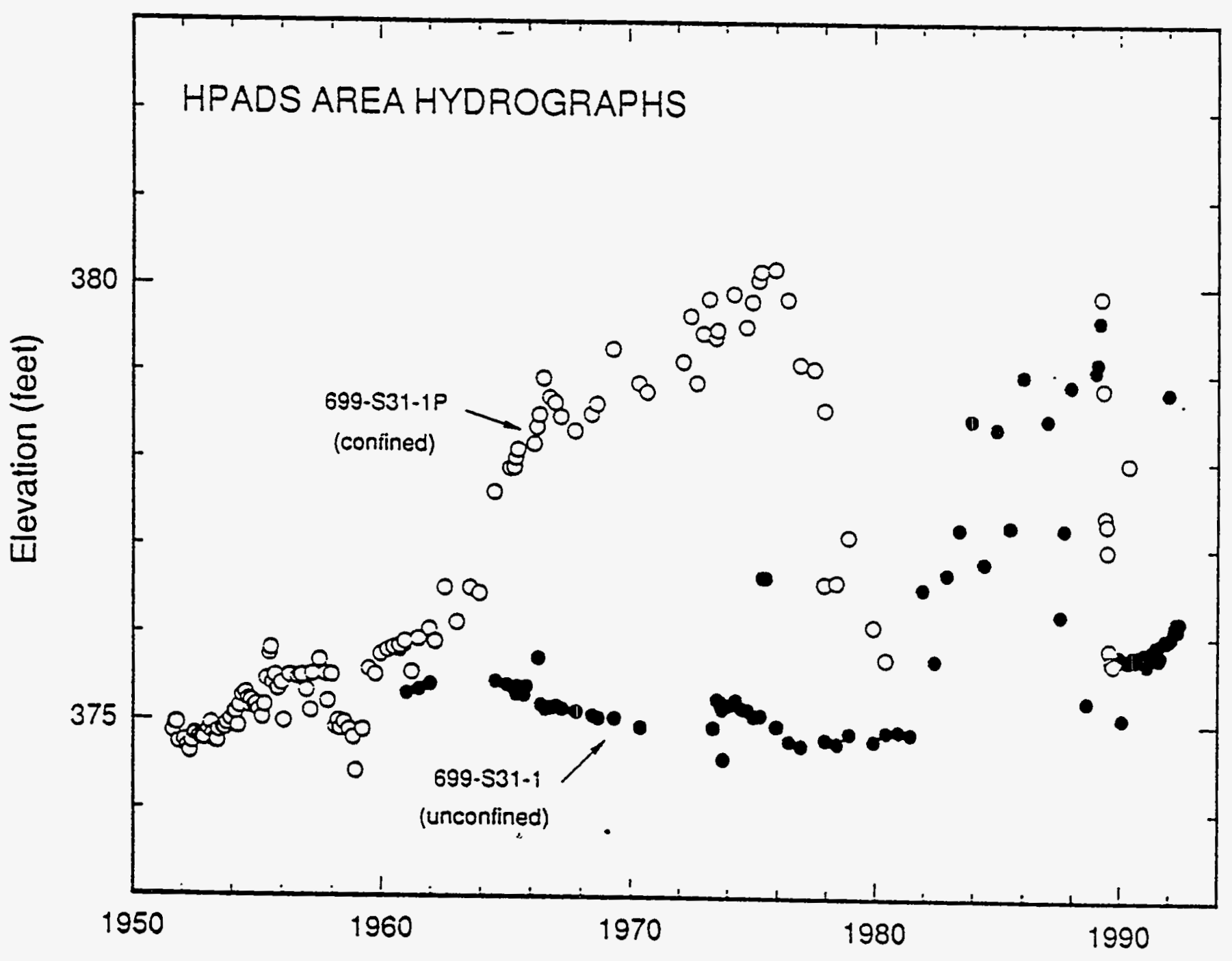

Figure 5A-4. Hydrographs for We11s 6-531-1 and 6-531-1P. 
$8 / 05 / 92$

Geosciences Group PARADOX Database

Hell Result Report

Page 1

HPADS Groundhater Data

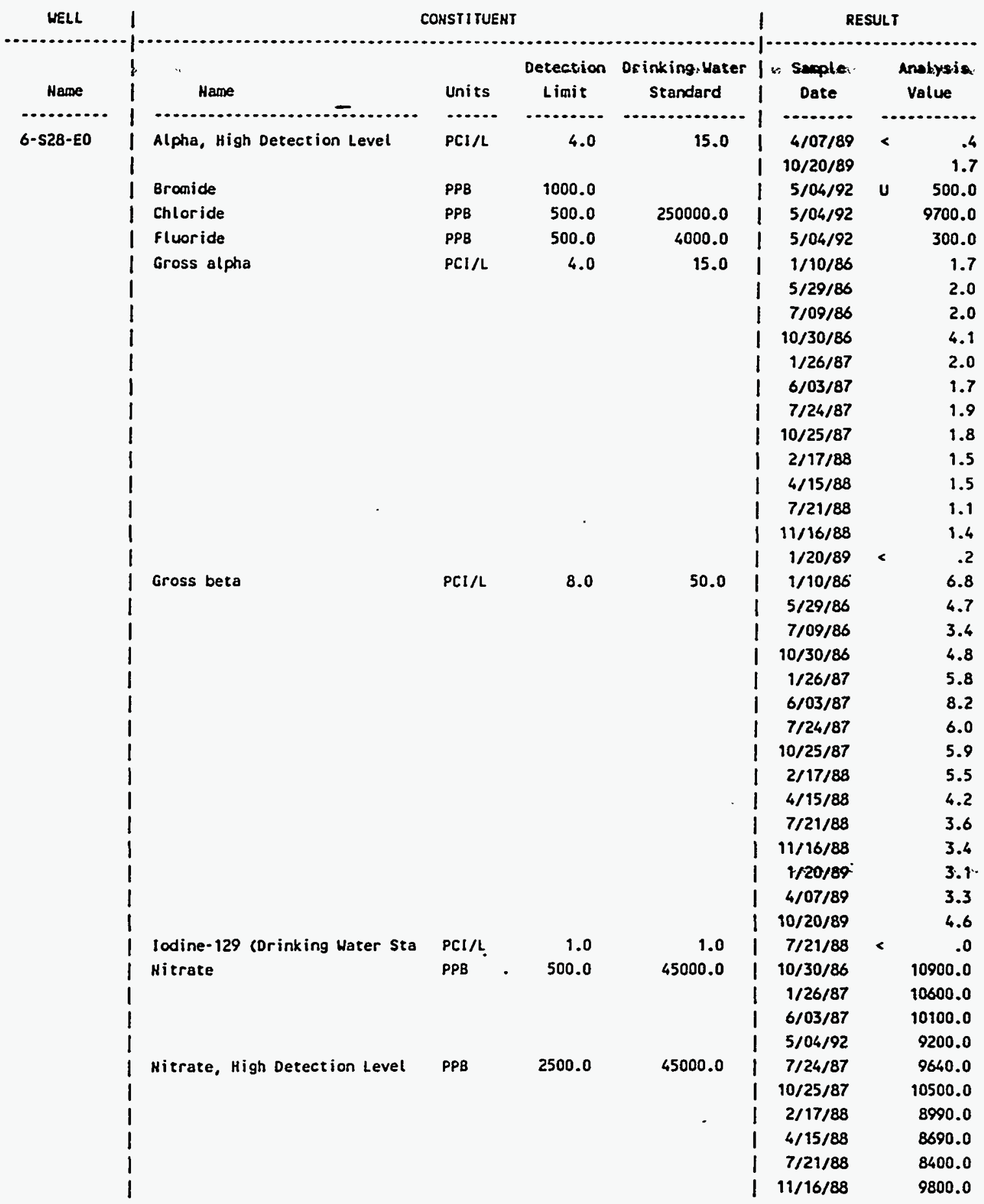

Figure 5A-5. Hater Quality Data. (sheet 1 of 24) 
Well Result Report

Page 2

HPAOS Groundwater Data

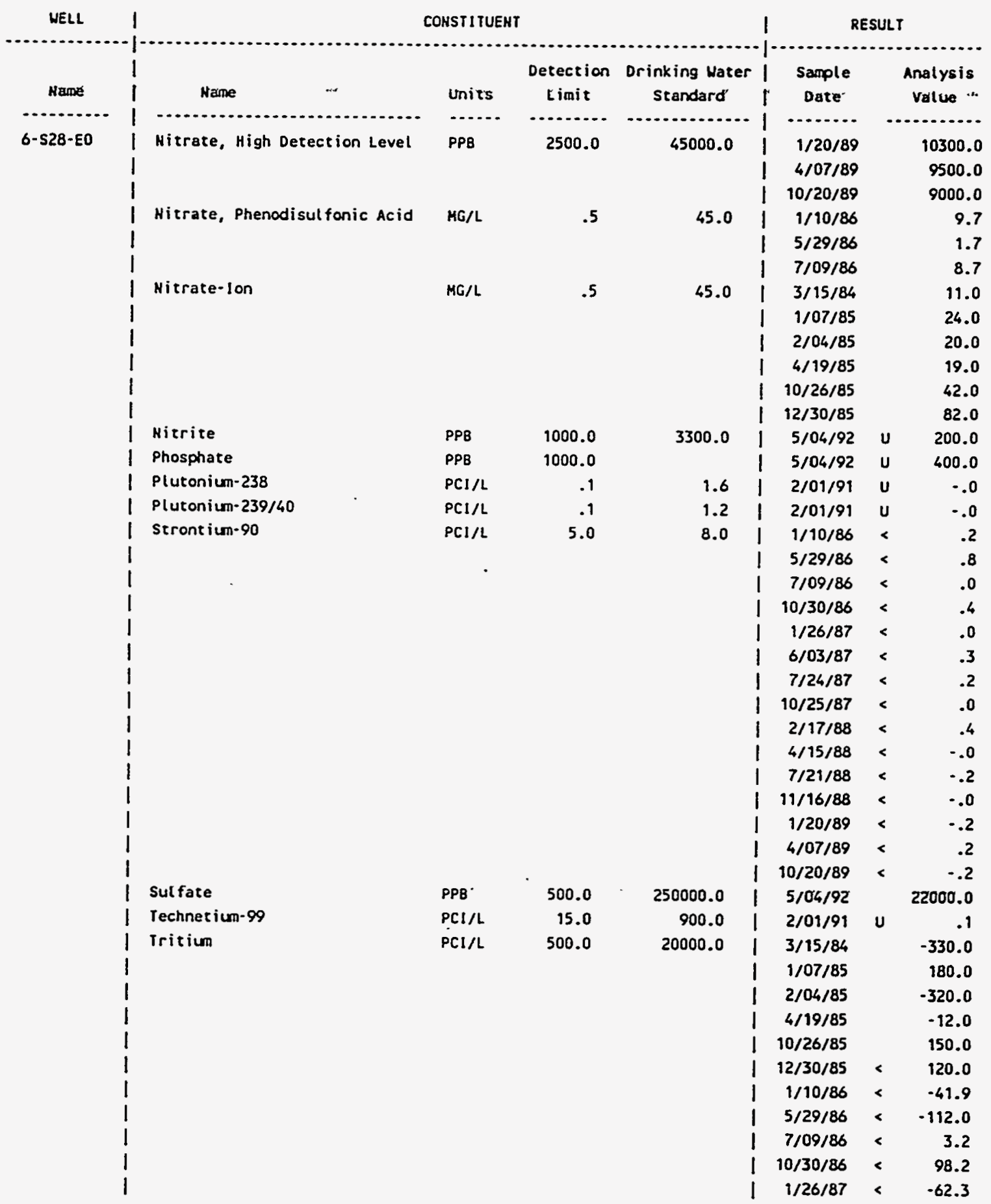

Figure 5A-5. Water Quality Data. (sheet 2 of 24) 


$\begin{array}{cc}\text { 8/05/92 } & \begin{array}{c}\text { Geosciences Group PARADOX Database } \\ \text { Hell Result Report }\end{array} \\ \text { HPADS Groundwater Data } & \text { Page }\end{array}$

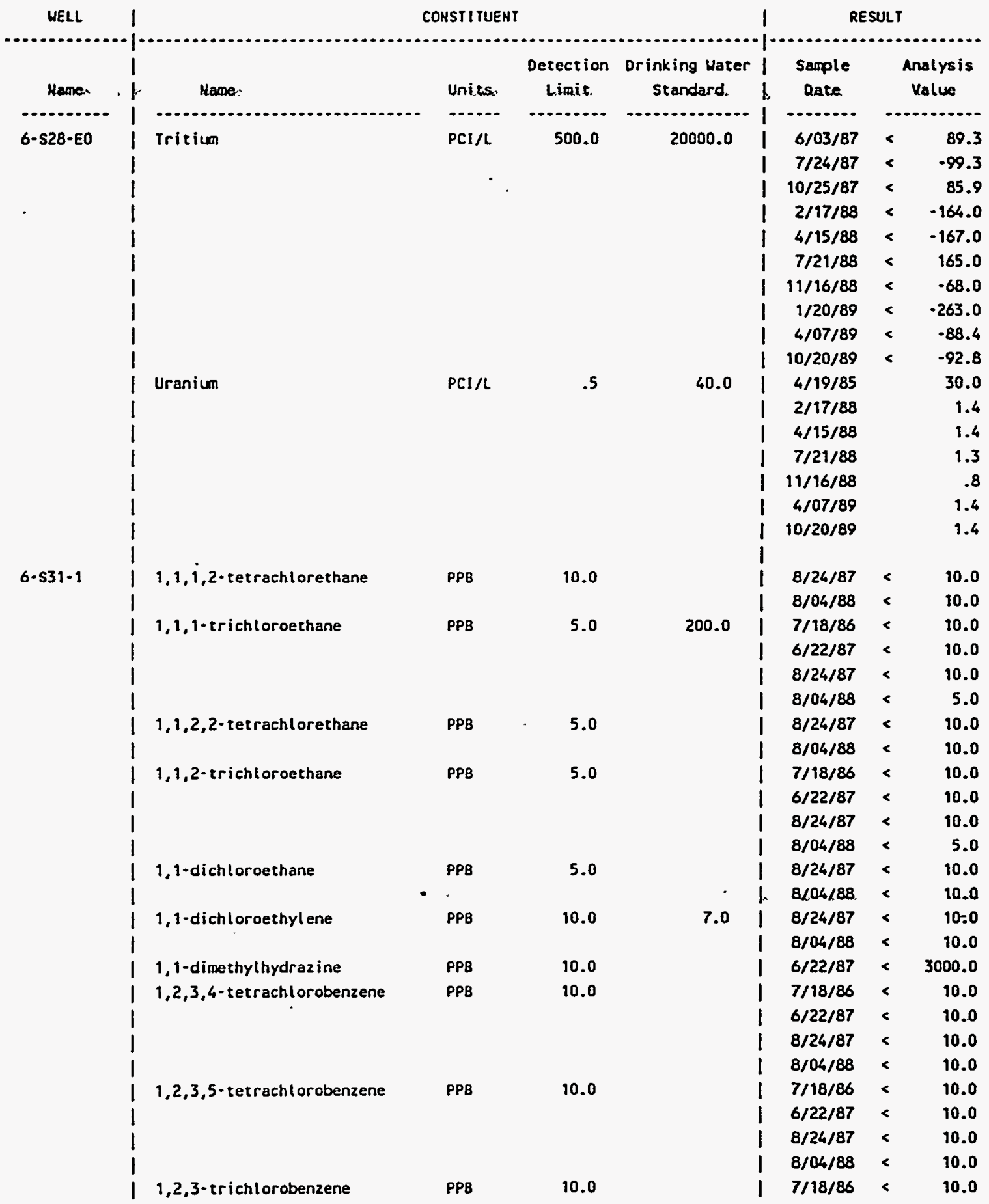

Figure 5A-5. Water Quality Data. (sheet 3 of 24) 
$8 / 05 / 92$

Geosciences Group PARADOX Database

Hell Result Report
HPADS Groundwater Data

\begin{tabular}{|c|c|c|c|c|c|c|c|c|c|}
\hline \multirow{2}{*}{$\begin{array}{l}\text { UELL } \\
\text { Name. }\end{array}$} & 1 & \multicolumn{4}{|c|}{ CONSTI IUENT } & 1 & \multicolumn{3}{|c|}{ RESULT } \\
\hline & 1. & Name o. & Units. & $\begin{array}{l}\text { Detection } \\
\text { Limit }\end{array}$ & $\begin{array}{c}\text { Drinking Hater } \\
\text { Standard }\end{array}$ & 1 & $\begin{array}{l}\text { Sample } \\
\text { Date, }\end{array}$ & & $\begin{array}{l}\text { nalysis } \\
\text { Value. }\end{array}$ \\
\hline (n............... & i & & ....... & ........... & - & 1 & ......... & $\cdots$ & ......... \\
\hline \multirow[t]{44}{*}{$6-531-1$} & i & 1,2,3-trichlorobenzene & PPB & 10.0 & & $i$ & $6 / 22 / 87$ & $<$ & 10.0 \\
\hline & 1 & & & & & 1 & $8 / 24 / 87$ & $<$ & 10.0 \\
\hline & 1 & & & & & i & $8 / 04 / 88$ & $<$ & 10.0 \\
\hline & 1 & 1,2,3-trichloropropane & PPB & 10.0 & & 1 & $8 / 24 / 87$ & $<$ & 10.0 \\
\hline & 1 & & & & & I & $8 / 04 / 88$ & $<$ & 10.0 \\
\hline & I & $1,2,4,5$-tetrachlorobenzene & PPB & 10.0 & & 1 & $7 / 18 / 86$ & $<$ & 10.0 \\
\hline & 1 & & & & & 1 & $6 / 22 / 87$ & $<$ & 10.0 \\
\hline & 1 & & & & & 1 & $8 / 24 / 87$ & $<$ & 10.0 \\
\hline & 1 & & & & & 1 & $8 / 04 / 88$ & $<$ & 10.0 \\
\hline & 1 & 1,2,4-trichlorobenzene & PPB & 10.0 & & 1 & $7 / 18 / 86$ & $<$ & 10.0 \\
\hline & 1 & & & & & 1 & $6 / 22 / 87$ & $<$ & 10.0 \\
\hline & 1 & & & & & 1 & $8 / 24 / 87$ & $<$ & 10.0 \\
\hline & 1 & & & & & 1 & $8 / 04 / 88$ & $<$ & 10.0 \\
\hline & 1 & 1,2-dibromo-3-chloropropane & PPB & 10.0 & .2 & 1 & $8 / 24 / 87$ & $<$ & 10.0 \\
\hline & 1 & & & & & 1 & $8 / 04 / 88$ & $<$ & 10.0 \\
\hline & I & 1,2-dibromoethane & PPB & 10.0 & & 1 & $8 / 24 / 87$ & $<$ & 10.0 \\
\hline & 1 & & & & & 1 & $8 / 04 / 88$ & $<$ & 10.0 \\
\hline & 1 & 1,2-dichlorobenzene & PPB & 10.0 & & 1 & $7 / 18 / 86$ & $<$ & 10.0 \\
\hline & 1 & & & & & 1 & $6 / 22 / 87$ & $<$ & 10.0 \\
\hline & 1 & & & & & 1 & $8 / 24 / 87$ & $<$ & 10.0 \\
\hline & 1 & & & & & 1 & $8 / 04 / 88$ & $<$ & 10.0 \\
\hline & 1 & 1,2-dichloroethane & PPB & 5.0 & 5.0 & 1 & $8 / 24 / 87$ & $<$ & 10.0 \\
\hline & 1 & & & & & 1 & $8 / 04 / 88$ & $<$ & 10.0 \\
\hline & 1 & 1,2-dichloropropane & PP8 & 5.0 & 5.0 & 1 & $8 / 24 / 87$ & $<$ & 10.0 \\
\hline & 1 & & & & & I & $8 / 04 / 88$ & $<$ & 10.0 \\
\hline & 1 & 1,2-dimethylhydraz ine & PPB & 10.0 & & 1 & $6 / 22 / 87$ & $<$ & 3000.0 \\
\hline & 1 & 1.2-diphenylhydrazine & PPB & 10.0 & & 1 & $8 / 04 / 88$ & $<$ & 10.0 \\
\hline & 1 & 1,3,5-trichlorobenzene & PPB & 10.0 & & 1 & $7 / 18 / 86$ & $<$ & 10.0 \\
\hline & 1 & & & & & 1 & $6 / 22 / 87$ & $<$ & 10.0 \\
\hline & 1 & & & & & 1 & $8 / 24 / 87$ & $<$ & 10.0 \\
\hline & 1 & $\cdot$ & & & & 1 & $8 / 04 / 88$ & $<$ & 10.0 \\
\hline & 1 & 1,3-dictrtorobenzene & PPB & 10.0 & & 1 & $7 / 18 / 86$ & $\bullet$ & 10,0 \\
\hline & 1 & & & & & 1 & $6 / 22 / 87$ & $<$ & 10.0 \\
\hline & 1 & & & & & 1 & $8 / 24 / 87$ & $<$ & 10.0 \\
\hline & 1 & & & & & 1 & $8 / 04 / 88$ & $<$ & 10.0 \\
\hline & 1 & 1,3-dichloropropene & PPB & 5.0 & & 1 & $8 / 24 / 87$ & $<$ & 10.0 \\
\hline & ! & & & & & 1 & $8 / 04 / 88$ & $<$ & 10.0 \\
\hline & I & 1.4-dichloro-2-butene & PPB & 10.0 & & 1 & $8 / 24 / 87$ & $<$ & 10.0 \\
\hline & 1 & & & & & 1 & $8 / 04 / 88$ & $<$ & 10.0 \\
\hline & I & 1,4-naph thoquinone & PPB & 10.0 & & 1 & $8 / 04 / 88$ & $<$ & 10.0 \\
\hline & I & 1-chloro-2,3-epoxypropane & PPB & 10.0 & & 1 & $8 / 04 / 88$ & $<$ & 10.0 \\
\hline & 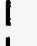 & 1-naphthylamine & PPB & 10.0 & & 1 & $8 / 04 / 88$ & $<$ & 10.0 \\
\hline & ! & $2,3,4,6$ - tetrachlorophenol & PPB & 10.0 & & 1 & $8 / 04 / 88$ & $<$ & 10.0 \\
\hline & I & $2,4,5-T$ & PPB & 2.0 & & 1 & $8 / 04 / 88$ & $<$ & 2.0 \\
\hline
\end{tabular}

Figure 5A-5. Water Quality Data. (sheet 4 of 24) 
Well Result Report

MPADS Groundwater Data

\begin{tabular}{|c|c|c|c|c|c|c|c|}
\hline HELL & 1 & OHST I TUEH & & & 1 & SUL & \\
\hline Mane- & 1 & Units. & $\begin{array}{l}\text { Detection } \\
\text { Limit }\end{array}$ & $\begin{array}{l}\text { Drinking Water } \\
\text { Standard }\end{array}$ & $\begin{array}{c}\text { Sample } \\
\text { Date }\end{array}$ & & $\begin{array}{l}\text { Analysis } \\
\text { Value }\end{array}$ \\
\hline$\ldots$ & | & $\cdots \ldots$ & $\ldots \ldots$ & - & $1 \quad \ldots \ldots \ldots$ & $\cdots$ & ................ \\
\hline $6-531-1$ & I 2,4,5-TP silvex & PPB & 2.0 & 10.0 & | $10 / 17 / 85$ & $<$ & 1.0 \\
\hline & 1 & & & & $7 / 18 / 86$ & $<$ & 1.0 \\
\hline & 1 & & & & $8 / 04 / 88$ & $<$ & 2.0 \\
\hline & I 2,4,5-Trichlorophenol & PPB & 10.0 & & $8 / 04 / 88$ & $<$ & 50.0 \\
\hline & I 2,4,6-trichlorophenol & PPB & 10.0 & & $8 / 04 / 88$ & $<$ & 10.0 \\
\hline & $12,4-0$ & PPB & 2.0 & 100.0 & $110 / 17 / 85$ & $<$ & 1.0 \\
\hline & 1 & & & & $7 / 18 / 86$ & $<$ & 1.0 \\
\hline & 1 & & & & $8 / 04 / 88$ & $<$ & 2.0 \\
\hline & I 2,4-dichlorophenol & PPB & 10.0 & & $8 / 04 / 88$ & $<$ & 10.0 \\
\hline & I 2,4-diwethylphenol & PPB & 10.0 & & $8 / 04 / 88$ & $<$ & 10.0 \\
\hline & | 2,4-dinitrophenol & PPB & 10.0 & & $8 / 04 / 88$ & $<$ & 50.0 \\
\hline & 1 2,4-dinitrotoluene & PPB & 10.0 & & $8 / 04 / 88$ & $<$ & 10.0 \\
\hline & I 2,6-dichlorophenol & PPB & 10.0 & & $8 / 04 / 88$ & $<$ & 10.0 \\
\hline & I 2,6-dinitrotoluene & PPB & 10.0 & & $8 / 04 / 88$ & $<$ & 10.0 \\
\hline & I 2-acetylaminofluorene & PPB & 10.0 & & $8 / 04 / 88$ & $<$ & 10.0 \\
\hline & I 2-chloroethyl vinyl ether & PPB & 5.0 & & $8 / 24 / 87$ & $<$ & 10.0 \\
\hline & 1 & & & & $8 / 04 / 88$ & $<$ & 10.0 \\
\hline & I 2-ch!oronaphthalene & PPB & 10.0 & & $8 / 04 / 88$ & $<$ & 10.0 \\
\hline & I 2-chlorophenol & PPB & 10.0 & & $18 / 04 / 88$ & $<$ & 10.0 \\
\hline & I 2-cyclohexyl-4,6-dinitrophenol & PPB & 10.0 & & $18 / 04 / 88$ & $<$ & 10.0 \\
\hline & 1 2-methyl-2-(methylthio) propio & PPB & 10.0 & & 1 $8 / 04 / 88$ & $<$ & 10.0 \\
\hline & I 2-methylaziridine & PPB & 10.0 & & $18 / 04 / 88$ & $<$ & 10.0 \\
\hline & I 2-methyllactonitrile & PPB & 10.0 & & $18 / 04 / 88$ & $<$ & 10.0 \\
\hline & | 2-naphthylamine & PPB & 10.0 & & $18 / 04 / 88$ & $<$ & 10.0 \\
\hline & I 2-picoline & PPB & 10.0 & & $8 / 04 / 88$ & $<$ & 10.0 \\
\hline & 1 2-propyn-1-ol & PPB & 10000.0 & & $6 / 22 / 87$ & $<$ & 3000.0 \\
\hline & 1 2-sec-butyl-4,6-dinitrophenol & PPB & 10.0 & & $18 / 04 / 88$ & $<$ & 10.0 \\
\hline & I 3,3'-0ichlorobenzidine & PPB & 10.0 & & $18 / 04 / 88$ & $<$ & 20.0 \\
\hline & 1 3,3'-dimethoxybenzidine & PPB & 10.0 & & $18 / 04 / 88$ & $<$ & 10.0 \\
\hline & 1 3,3'-dimethylbenzidine & PPB & 10.0 & & $18 / 04 / 88$ & $<$ & 10.0 \\
\hline & 1 3-chloropropionitrile & PPB & 10000.0 & & $16 / 22 / 87$ & $<$ & 3000.0 \\
\hline & I 3-methylchol anthrene & PPB : & 10.0 & & $8 / 04 / 88$ & $<$ & 10.0. \\
\hline & I 4,4'-methylenebis(2-chloroanil & PPB & 10.0 & & $8 / 04 / 88$ & $<$ & 10.0 \\
\hline & I 4,6-dinitro-0-cresol and salts & PPB & 10.0 & & $8 / 04 / 88$ & $<$ & 10.0 \\
\hline & I 4-aminobyphenyl & PPB & 10.0 & & $8 / 04 / 88$ & $<$ & 10.0 \\
\hline & I 4-bromophenyl phenyl ether & PPB & 10.0 & & $8 / 04 / 88$ & $<$ & 10.0 \\
\hline & I 5-(aminanethyl)-3-isoxazolol & PPB & 10.0 & & $8 / 04 / 88$ & $<$ & 10.0 \\
\hline & I-nitro-o-toluidine & PPB & 10.0 & & $8 / 04 / 88$ & $<$ & 10.0 \\
\hline & I 7,12-dimethylbenz [a] anthracene & PPB & 10.0 & & $8 / 04 / 88$ & $<$ & 10.0 \\
\hline & I 7H-dibenzolc,s] carbazole & PPB & 10.0 & & $8 / 04 / 88$ & $<$ & 10.0 \\
\hline & Acetonitrile & PPB & 10.0 & & $6 / 22 / 87$ & $<$ & 3000.0 \\
\hline & 1 & & & & $8 / 04 / 88$ & $<$ & 3000.0 \\
\hline & I Acetophenone & PPB & 10.0 & & $8 / 04 / 88$ & $<$ & 10.0 \\
\hline & Acrolein & PPB & 10.0 & & $8 / 24 / 87$ & $<$ & 10.0 \\
\hline
\end{tabular}

Figure 5A-5. Water Quality Data. (sheet 5 of 24) 
$8 / 05 / 92$

Geosciences Group PARADOX Database

Hell Result Report

Page 6

HPADS Groundwater Data

\begin{tabular}{|c|c|c|c|c|c|c|c|c|}
\hline WELL & \multicolumn{5}{|c|}{ CONSTI IUENT } & \multicolumn{3}{|c|}{ RESULT } \\
\hline Hame & $i$ & Hame & Units & $\begin{array}{l}\text { Detection } \\
\text { Limit }\end{array}$ & $\begin{array}{l}\text { Drinking Hater } \\
\text { Standard }\end{array}$ & $\begin{array}{l}\text { I Sample } \\
\text { I. Date }\end{array}$ & & $\begin{array}{l}\text { Analysis } \\
\text { Vatue }\end{array}$ \\
\hline -.......... & 1 & м..., & $\ldots . .$. & .......... & & $1 \ldots \ldots$ & .. & .......... \\
\hline \multirow[t]{44}{*}{$6-531-1$} & i & Acrolein & PPB & 10.0 & & $8 / 04 / 88$ & $<$ & 10.0 \\
\hline & i & Acrylamide & PPB & 10000.0 & & $6 / 22 / 87$ & $<$ & 3000.0 \\
\hline & 1 & Acrylonitrile & PPB & 10.0 & & $8 / 24 / 87$ & $<$ & 10.0 \\
\hline & i & & & & & $8 / 04 / 88$ & $<$ & 10.0 \\
\hline & i & Aldrin & PPB & .1 & & $8 / 04 / 88$ & $<$ & .1 \\
\hline & $i$ & Alkal inity & & 20000.0 & & $6 / 22 / 87$ & & 89300.0 \\
\hline & i & . & & & & i $8 / 24 / 87$ & & 91100.0 \\
\hline & i & & & & & $8 / 04 / 88$ & & 94200.0 \\
\hline & i & & & & & $12 / 20 / 91$ & & 97.0 \\
\hline & i & Allyl alcohol & PPB & 10000.0 & & i $6 / 22 / 87$ & $<$ & 3000.0 \\
\hline & 1 & Alpha, alpha-dimethylphenethyla & PPB & 10.0 & & $8 / 04 / 88$ & $<$ & 10.0 \\
\hline & 1 & Alpha-BHC & PPB & .9 & 4.0 & i 10/17/85 & $<$ & 1.0 \\
\hline & $i$ & & & & & i $7 / 18 / 86$ & $<$ & 1.0 \\
\hline & 1 & & & & & i $8 / 04 / 88$ & $<$ & .1 \\
\hline & i & Aluminum & PPB & 150.0 & 50.0 & $10 / 17 / 85$ & $<$ & 150.0 \\
\hline & i & & & & & i $8 / 04 / 88$ & $<$ & 150.0 \\
\hline & 1 & Aluminum, filtered & PPB & 150.0 & 50.0 & $6 / 22 / 87$ & $<$ & 150.0 \\
\hline & i & & & & & $8 / 24 / 87$ & $<$ & 150.0 \\
\hline & 1 & & & & & $8 / 04 / 88$ & $<$ & 150.0 \\
\hline & 1 & Amitrole & PPB & 10.0 & & $8 / 04 / 88$ & $<$ & 10.0 \\
\hline & i & Amonium ion & PPB & 50.0 & & $6 / 22 / 87$ & & 70.0 \\
\hline & 1 & & & & & $8 / 24 / 87$ & $<$ & 50.0 \\
\hline & 1 & & & & & $8 / 04 / 88$ & $<$ & 50.0 \\
\hline & i & Aniline & PPB & 10.0 & & i $8 / 04 / 88$ & $<$ & 10.0 \\
\hline & i & Ancimony & PPB & .100 .0 & & i $10 / 17 / 85$ & $<$ & 100.0 \\
\hline & 1 & & & & & $8 / 04 / 88$ & $<$ & 100.0 \\
\hline & $i$ & Antimony, filtered & PPB & 100.0 & & $6 / 22 / 87$ & $<$ & 100.0 \\
\hline & 1 & & & & & $8 / 24 / 87$ & $<$ & 100.0 \\
\hline & 1 & & & & & i $8 / 04 / 88$ & $<$ & 100.0 \\
\hline & 1 & & & & & | $12 / 20 / 91$ & $u$ & 200.0 \\
\hline & i & Aramite & PPB & 10.0 & & $8 / 04 / 88$ & $<$ & 10.0 \\
\hline & i & Arochlor 1016 & PPB & 1.0 & .5 & $8 / 04 / 88$ & $<$ & 1.0 \\
\hline & I & Arochlor 1221 & PPB & 1.0 & .5 & $8 / 04 / 88$ & $<$ & 1.0 \\
\hline & 1 & Arochlor 1232 & PPB & 1.0 & .5 & $8 / 04 / 88$ & $<$ & 1.0 \\
\hline & 1 & Arochlor 1242 & PPB & 1.0 & .5 & $8 / 04 / 88$ & $<$ & 1.0 \\
\hline & $i$ & Arochlor 1248 & PPB & 1.0 & .5 & $8 / 04 / 88$ & $<$ & 1.0 \\
\hline & i & Arochlor 1254 & PPB & 1.0 & .5 & $8 / 04 / 88$ & $<$ & 1.0 \\
\hline & I & Arochlor 1260 & PPB & 1.0 & .5 & $8 / 04 / 88$ & $<$ & 1.0 \\
\hline & i & Arsenic & PPB & 5.0 & 50.0 & | $10 / 17 / 85$ & $<$ & 5.0 \\
\hline & i & & & & & i $8 / 04 / 88$ & & 6.0 \\
\hline & 1 & Arsenic, filtered & PPB & 5.0 & 50.0 & $6 / 22 / 87$ & $<$ & 5.0 \\
\hline & i & & & & & i $8 / 24 / 87$ & & 6.0 \\
\hline & I & & & & & $8 / 04 / 88$ & & 6.0 \\
\hline & I & Auramine & PPB & 10.0 & & $8 / 04 / 88$ & $<$ & 10.0 \\
\hline
\end{tabular}

Figure 5A-5. Water Quality Data. (sheet 6 of 24) 


\begin{tabular}{cc}
\hline Hell Result Report & Page 7 \\
HPADS Groundwater Data
\end{tabular}

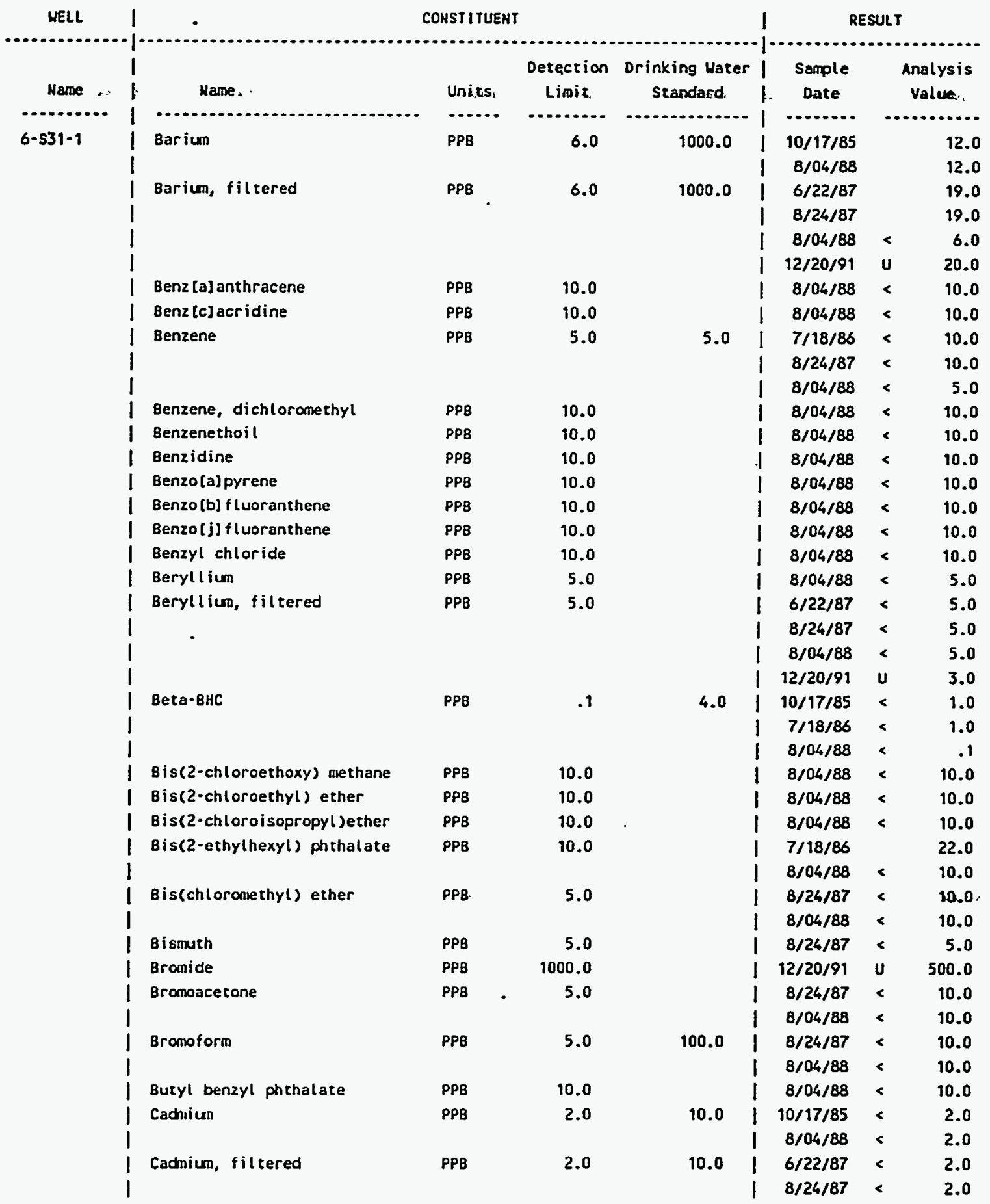

Figure.5A-5. Water Quality Data. (sheet 7 of 24) 
Hell Result Report

HPADS Groundwater Data

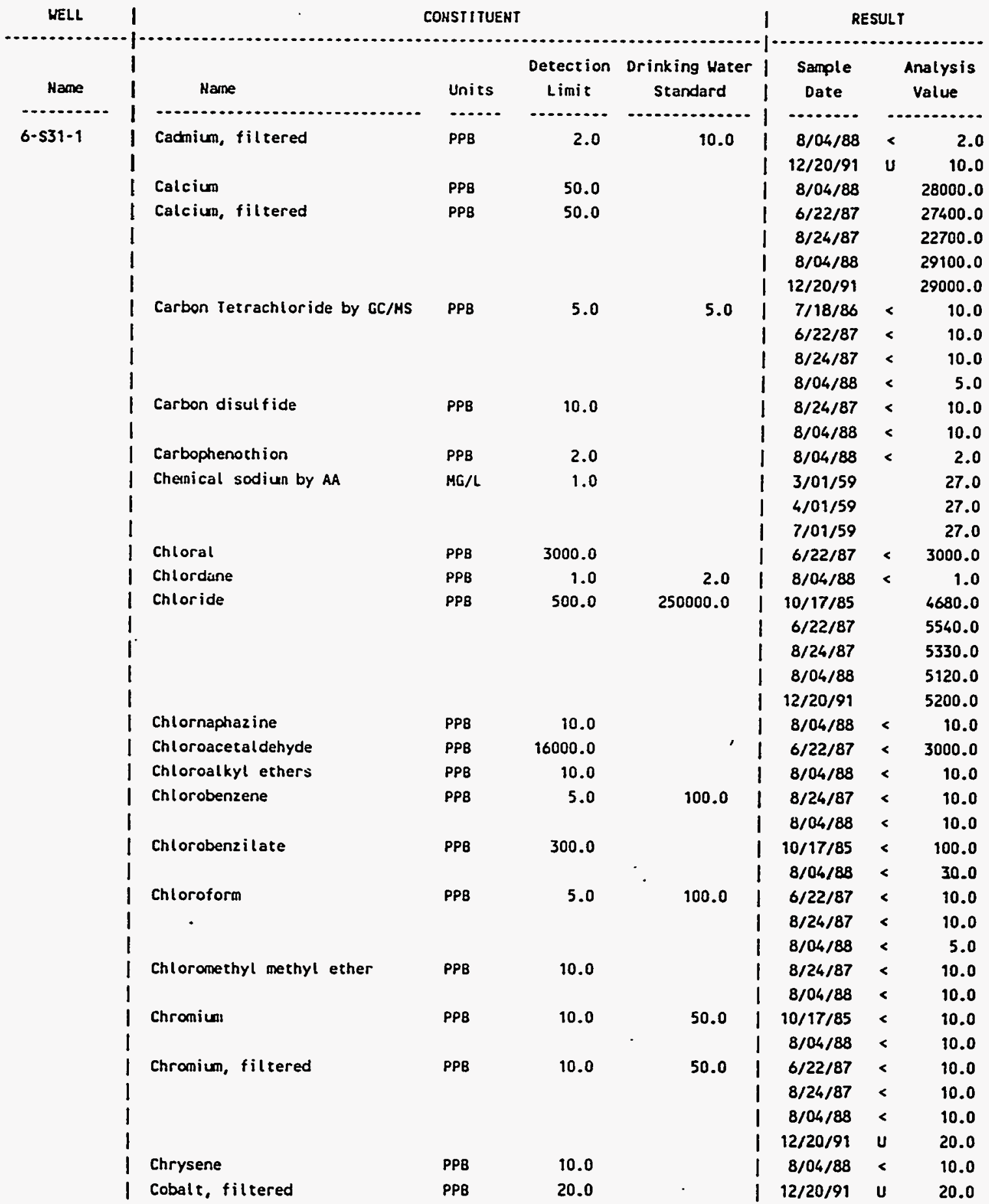

Figure 5A-5. Water Quality Data. (sheet 8 of 24) 
Hell Result Report

HPADS Groundwater Data

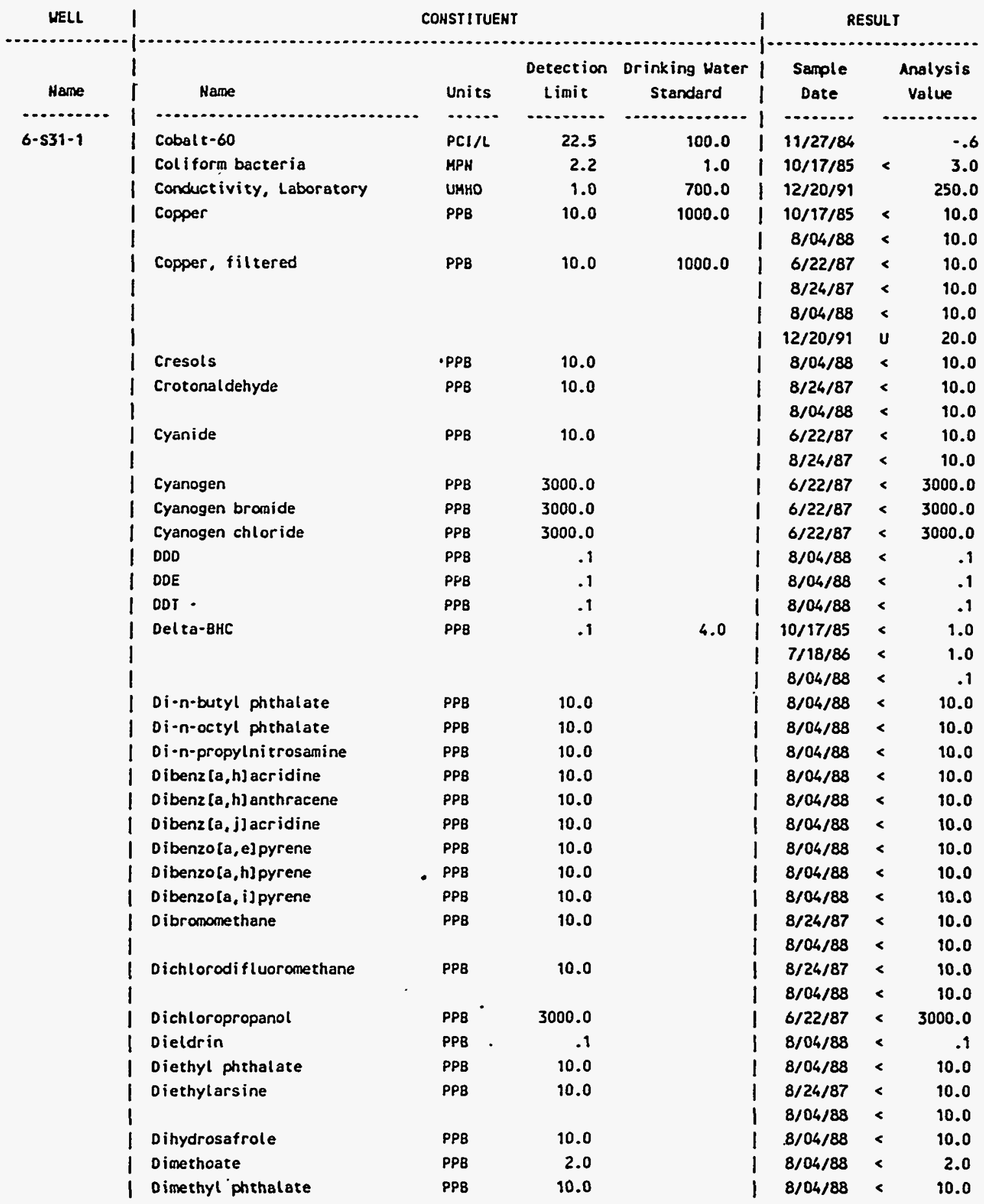

Figure 5A-5. Water Quality Data. (sheet 9 of 24) 
$8 / 05 / 92$

Geosciences Group PARADOX Database

$\begin{array}{cc}\text { Hell Result Report } & \text { Page } 10 \\ \text { HPADS Groundwater Data }\end{array}$

\begin{tabular}{|c|c|c|c|c|c|c|c|c|}
\hline $\begin{array}{c}\text { MELL } \\
\end{array}$ & \multicolumn{5}{|c|}{ CONSTI IUENT } & \multicolumn{3}{|c|}{ RESULT } \\
\hline & $i$ & & & Detection & Drinking Water & Sample & & inalysis \\
\hline Hane & 1 & Mame & Units & Limit & standard" & Date & . & Vatue \\
\hline (.............. & 1 & - & $\cdots \cdots$ & $\cdots \ldots$ & $\ldots \ldots+\ldots$ & $1 \quad \ldots \ldots$. & -- & (n........ \\
\hline \multirow[t]{44}{*}{$6-531-1$} & 1 & Dinitrobenzene & PPB & 10.0 & & $8 / 04 / 88$ & $<$ & 10.0 \\
\hline & i & Dioxane & PेPB & 500.0 & & $7 / 18 / 86$ & $<$ & 500.0 \\
\hline & 1 & & & & & $8 / 24 / 87$ & $<$ & 500.0 \\
\hline & 1 & & & & & $8 / 04 / 88$ & $<$ & 500.0 \\
\hline & i & Diphenylamine & PPB & 10.0 & & $8 / 04 / 88$ & $<$ & 10.0 \\
\hline & 1 & Disutfoton & PPB & 2.0 & & $8 / 04 / 88$ & $<$ & 2.0 \\
\hline & 1 & Endosul fan I & PPB & .1 & & i $8 / 04 / 88$ & $<$ & .1 \\
\hline & $i$ & Endosulfan II & PPB & .1 & & $8 / 04 / 88$ & $<$ & .1 \\
\hline & 1 & Endrin & PPB & .1 & .2 & i 10/17/85 & $<$ & 1.0 \\
\hline & i & & & & & $17 / 18 / 86$ & $<$ & 1.0 \\
\hline & 1 & & & & & | $8 / 04 / 88$ & $<$ & .1 \\
\hline & $i$ & Ethyl carbamate & PPB & 10000.0 & & $6 / 22 / 87$ & $<$ & 3000.0 \\
\hline & i & Ethyl cyanide & PPB & 10000.0 & & $6 / 22 / 87$ & $<$ & 3000.0 \\
\hline & 1 & Ethyl methacrylate & PPB & 10.0 & & $8 / 24 / 87$ & $<$ & 10.0 \\
\hline & 1 & & & & & $8 / 04 / 88$ & $<$ & 10.0 \\
\hline & 1 & Ethyl methanesul fonate & PPB & 10.0 & & $8 / 04 / 88$ & $<$ & 10.0 \\
\hline & I & Ethylene glycol & PPB & 10000.0 & & $8 / 04 / 88$ & $<$ & 10000.0 \\
\hline & i & Ethylene oxide & PPB & 10.0 & & $6 / 22 / 87$ & $<$ & 3000.0 \\
\hline & i & & & & & $8 / 04 / 88$ & $<$ & 3000.0 \\
\hline & i & Ethyleneimine & PPB & 10.0 & & $8 / 04 / 88$ & $<$ & 10.0 \\
\hline & i & Fluoranthene & PPB & 10.0 & & $8 / 04 / 88$ & $<$ & 10.0 \\
\hline & $i$ & Fluoride & PPB & 500.0 & 4000.0 & $10 / 17 / 85$ & $<$ & 500.0 \\
\hline & 1 & & & & & i $6 / 22 / 87$ & $<$ & 500.0 \\
\hline & $i$ & & & & & i $8 / 24 / 87$ & $<$ & 500.0 \\
\hline & i & & & & & i $8 / 04 / 88$ & $<$ & 500.0 \\
\hline & 1 & & & & & $12 / 20 / 91$ & & 200.0 \\
\hline & $i$ & Fluoride, Low Detection Level & PPB & 20.0 & 4000.0 & $8 / 24 / 87$ & & 250.0 \\
\hline & 1 & Fluoroacetic acid & PPB & 3000.0 & & $6 / 22 / 87$ & $<$ & 3000.0 \\
\hline & $i$ & formal in & PPB & 500.0 & & $7 / 18 / 86$ & $<$ & 500.0 \\
\hline & $i$ & & & & & $8 / 24 / 87$ & $<$ & 500.0 \\
\hline & $i$ & . & & & & $8 / 04 / 88$ & $<$ & 500.0 \\
\hline & 1 & Gamma-BHC & $\mathrm{PPB}$ & .1 & 4.0 & i $10 / 17 / 85$ & $<$ & 1.0 \\
\hline & $i$ & & & & & $17 / 18 / 86$ & $<$ & 1.0 \\
\hline & $i$ & & & & & i $8 / 04 / 88$ & $<$ & .1 \\
\hline & i & Glycidylaldehyde & PPB & 3000.0 & & $16 / 22 / 87$ & $<$ & 3000.0 \\
\hline & 1 & Gross alpha & $\mathrm{PCI} / \mathrm{L}$ & 4.0 & 15.0 & i $10 / 17 / 85$ & & 1.2 \\
\hline & $i$ & & & & & i $6 / 22 / 87$ & $<$ & .7 \\
\hline & 1 & & & & & $18 / 24 / 87$ & $<$ & .2 \\
\hline & $i$ & Gross beta & $\mathrm{PCl} / \mathrm{L}$ & 8.0 & 50.0 & i 11/01/51 & & 4.2 \\
\hline & $i$ & & & & & $1 / 01 / 52$ & & B.0 \\
\hline & $i$ & & & & & i $2 / 01 / 52$ & & 24.0 \\
\hline & $i$ & & & & & $13 / 01 / 52$ & & 23.0 \\
\hline & $i$ & & & & & | 4/01/52 & & 13.0 \\
\hline & $i$ & & & & & 1 $9 / 01 / 52$ & & .4 \\
\hline
\end{tabular}

Figure 5A-5. Water Quality Data. (sheet 10 of 24) 


8/05/92
$\frac{\text { Geosciences Group PARADOX Database }}{\text { Hell Result Report }}$ Page 11

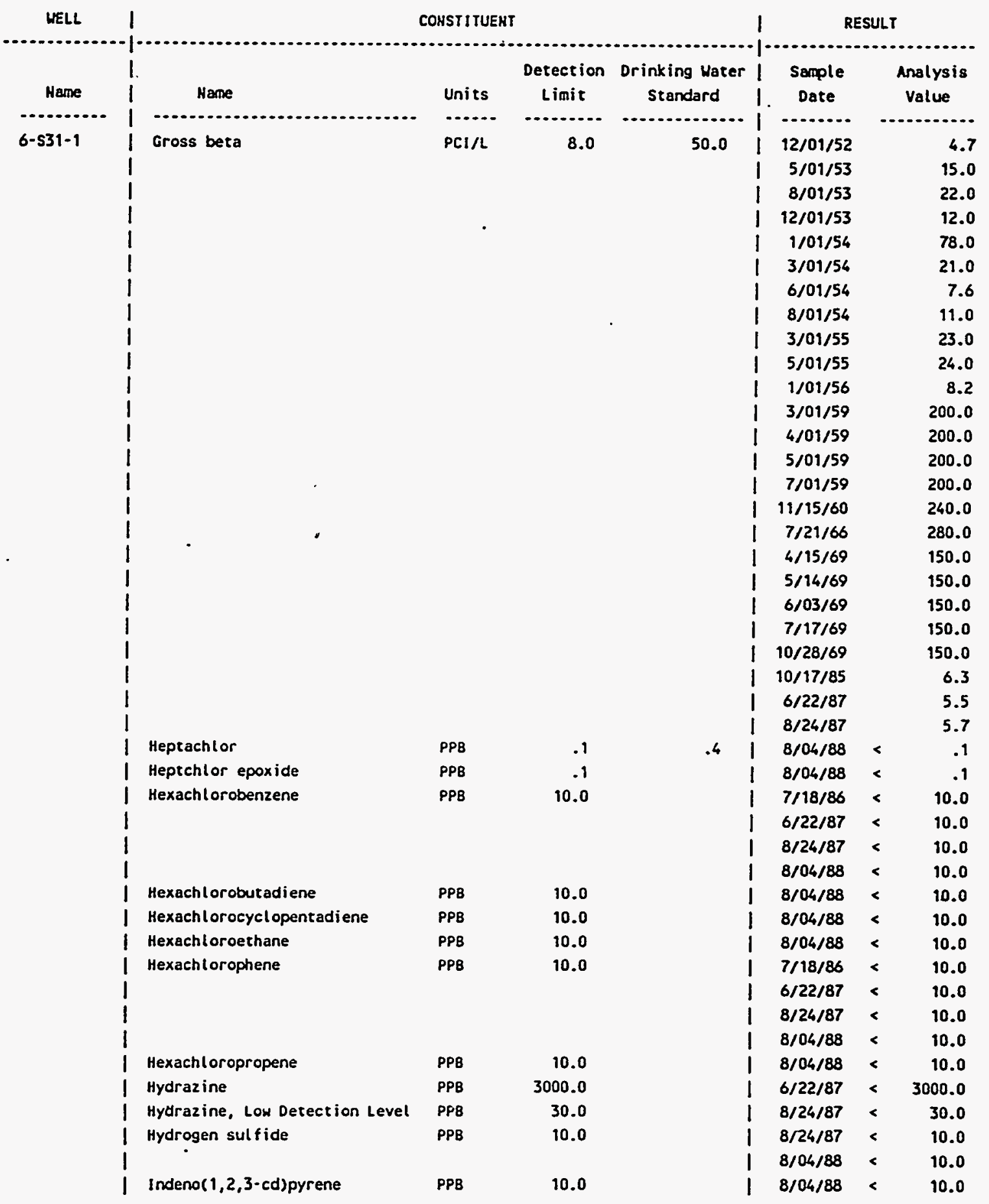

Figure 5A-5. Water Quality Data. (sheet 11 of 24) 
$8 / 05 / 92$

Geosciences Group PARADOX Database

$\begin{array}{cc}\text { Hell Result Report } & \text { Page } 12 \\ \text { HPADS Groundwater Data } & \end{array}$

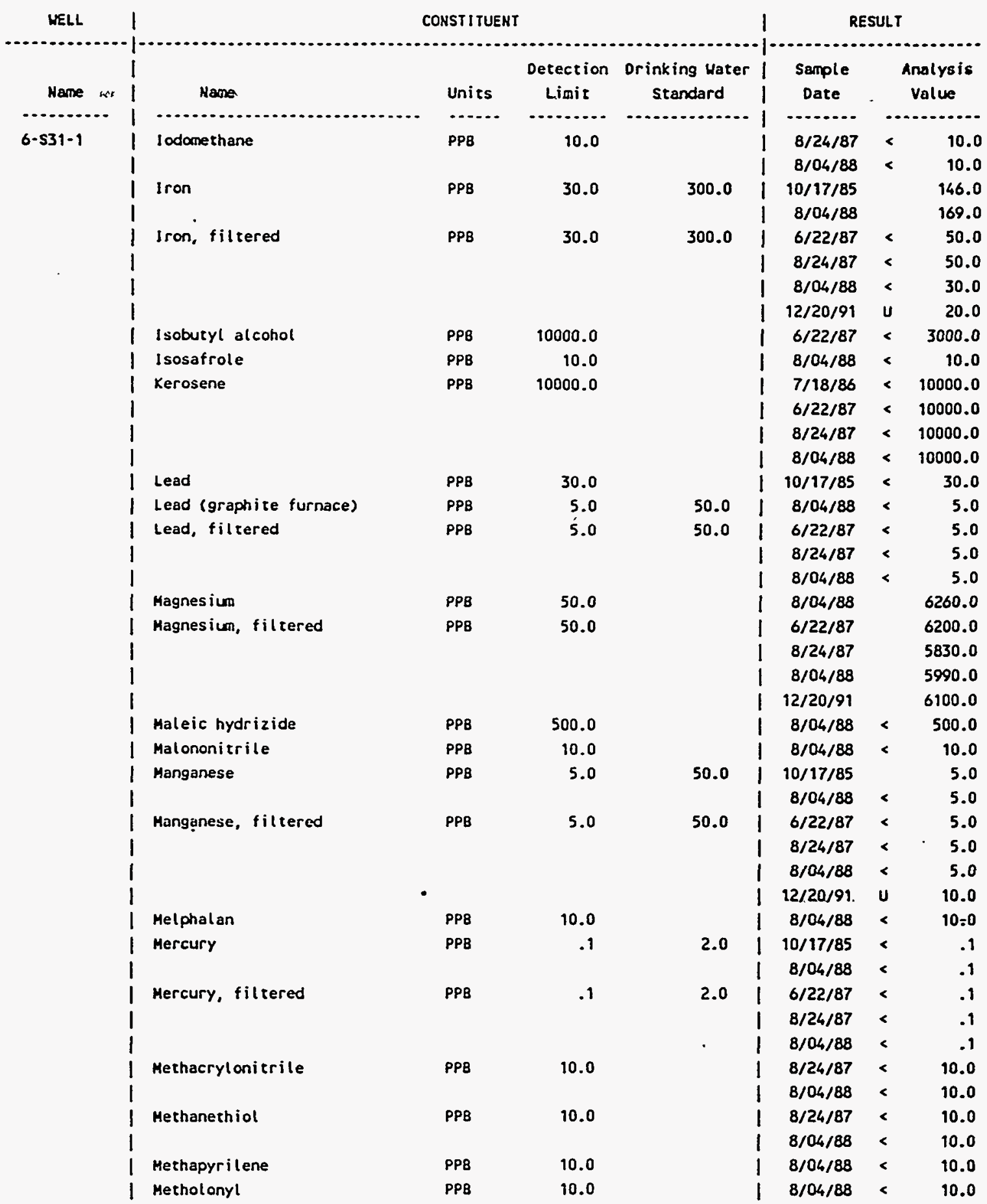

Figure 5A-5. Water Quality Data. (sheet 12 of 24) 


8/05/92 $\frac{\text { Geosciences Group PARADOX Database }}{\text { Well Result Report }}$
HPADS Groundwater Data

\begin{tabular}{|c|c|c|c|c|c|c|c|}
\hline MELL & 1 & LHST I TUEI & & & I & UL & \\
\hline Mane & $\begin{array}{l}1 \\
1\end{array}$ & Units & $\begin{array}{l}\text { Detection } \\
\text { Limit }\end{array}$ & $\begin{array}{l}\text { Drinking Water } \\
\text { Standard }\end{array}$ & $\begin{array}{l}\text { Sample } \\
\text { Date }\end{array}$ & & $\begin{array}{l}\text { Inalysis } \\
\text { Value }\end{array}$ \\
\hline - & | & -...... & $\ldots \ldots$ & . & $1 \quad \ldots \ldots$ & &...- \\
\hline $6 \cdot 531-1$ & I Methoxychlor & PPB & 3.0 & 100.0 & i $10 / 17 / 85$ & $<$ & 1.0 \\
\hline & 1 & & & & $7 / 18 / 86$ & $<$ & 9.0 \\
\hline & 1 & & & & $8 / 04 / 88$ & $<$ & 3.0 \\
\hline & I Methyl Isobutyl Ketone & PPB & 10.0 & & $8 / 04 / 88$ & $<$ & 10.0 \\
\hline & I Hethyl bromide & PPB & 10.0 & & $8 / 24 / 87$ & $<$ & 10.0 \\
\hline & 1 & & & & $8 / 04 / 88$ & $<$ & 10.0 \\
\hline & I Methyl chloride & PPB & 10.0 & & $8 / 24 / 87$ & $<$ & 10.0 \\
\hline & I & & & & $8 / 04 / 88$ & $<$ & 10.0 \\
\hline & I Methyl ethyl ketone & PPB & 10.0 & & $7 / 18 / 86$ & $<$ & 10.0 \\
\hline & 1 & & & & | $6 / 22 / 87$ & $<$ & 10.0 \\
\hline & 1 & & & & I $8 / 24 / 87$ & $<$ & 10.0 \\
\hline & 1 & & & & $8 / 04 / 88$ & $<$ & 10.0 \\
\hline & I Hethyl hydrazine & PPB & 3000.0 & & $6 / 22 / 87$ & $<$ & 3000.0 \\
\hline & I Hethyl methacrylate & PPB & 10.0 & & $8 / 24 / 87$ & $<$ & 10.0 \\
\hline & 1 & & & & $8 / 04 / 88$ & $<$ & 10.0 \\
\hline & I Methyl methanesulfonate & PPB & 10.0 & & $8 / 04 / 88$ & $<$ & 10.0 \\
\hline & I Methyl parathion & PPB & 2.0 & & $8 / 04 / 88$ & $<$ & 2.0 \\
\hline & I Methylene Chloride & PPB & 5.0 & & $6 / 22 / 87$ & & 44.0 \\
\hline & 1 & & & & $18 / 24 / 87$ & $<$ & 10.0 \\
\hline & I & & & & $18 / 04 / 88$ & $<$ & 10.0 \\
\hline & I Methylthiouracil & PPB & 10.0 & & $8 / 04 / 88$ & $<$ & 10.0 \\
\hline & I H,H-diethylhydrazine & PPB & 10.0 & & $8 / 24 / 87$ & $<$ & 10.0 \\
\hline & 1 & & & & $8 / 04 / 88$ & $<$ & 10.0 \\
\hline & | $H$-nitroso-H-methylurethane & PPB & 10.0 & & $8 / 04 / 88$ & $<$ & 10.0 \\
\hline & I N-nitrosodi-n-butylamine & PPB & 10.0 & & $8 / 04 / 88$ & $<$ & 10.0 \\
\hline & I N-nitrosodiethanolamine & PPB & 10.0 & & $8 / 04 / 88$ & $<$ & 10.0 \\
\hline & I N-nitrosodiethylamine & PPB & 10.0 & & $8 / 04 / 88$ & $<$ & 10.0 \\
\hline & | H-nitrosodimethylamine & PPB & 10.0 & & $8 / 04 / 88$ & $<$ & 10.0 \\
\hline & I N-nitrosomethylethylamine & PPB & 10.0 & & $8 / 04 / 88$ & $<$ & 10.0 \\
\hline & | N-nitrosomethylvinylamine & PPB & 10.0 & & $8 / 04 / 88$ & $<$ & 10.0 \\
\hline & I H-nitrosonorpholine & PPB & 10.0 & & $8 / 04 / 88$ & $<$ & 10.0 \\
\hline & I N-nitrosonornicotine & PPB & 10.0 & & $8 / 04 / 88$ & $<$ & 10.0 \\
\hline & I H-nitrosopiperidine & PPB & 10.0 & & $8 / 04 / 88$ & $<$ & 10.0 \\
\hline & I H-propylamine & PPB & 10000.0 & & $6 / 22 / 87$ & $<$ & 3000.0 \\
\hline & I Naphthalene & PPB & 10.0 & & $7 / 18 / 86$ & $<$ & 10.0 \\
\hline & 1 & . & & & $6 / 22 / 87$ & $<$ & 10.0 \\
\hline & I & - & & & $8 / 24 / 87$ & $<$ & 10.0 \\
\hline & 1 & & & & $8 / 04 / 88$ & $<$ & 10.0 \\
\hline & I Nickel & PPB & 10.0 & & | $10 / 17 / 85$ & $<$ & 10.0 \\
\hline & - & & & & $8 / 04 / 88$ & $<$ & 10.0 \\
\hline & I Hickel, filtered & PPB & 10.0 & & $6 / 22 / 87$ & $<$ & 10.0 \\
\hline & 1 & & & & $8 / 24 / 87$ & $<$ & 10.0 \\
\hline & 1 & & & & I $8 / 04 / 88$ & $<$ & 10.0 \\
\hline & 1 & & & & I 12/20/91 & u & 30.0 \\
\hline
\end{tabular}

Figure 5A-5. Water Quality Data. (sheet 13 of 24) 
Well Result Report

HPADS Groundwater Data

\begin{tabular}{|c|c|c|c|c|c|c|c|}
\hline MELL & 1 & \multicolumn{4}{|c|}{ COHSTI IUEAT } & \multicolumn{2}{|c|}{ RESULT } \\
\hline & i & & & Detection & Drinking Water & Sample & Analysis \\
\hline Hame & 1 & Hame & Units & Limit & Standard & I "Date & vatue' \\
\hline (............. & 1 & - & ...... & $\ldots \ldots$ & $\ldots+\ldots$ & $1 \ldots \ldots$ & ................ \\
\hline $6-531-1$ & 1 & Nicotinic acid & PPB & 100.0 & & $8 / 04 / 88$ & 100.0 \\
\hline & i & Hitrate & PPB & 500.0 & 45000.0 & $10 / 17 / 85$ & 2860.0 \\
\hline & 1 & & & & & 1 $6 / 22 / 87$ & 3430.0 \\
\hline & 1 & & & & & $8 / 24 / 87$ & 3480.0 \\
\hline & i & & & & & $8 / 04 / 88$ & 3620.0 \\
\hline & i & & & & & i $12 / 20 / 91$ & 900.0 \\
\hline & $i$ & Mitrate, Phenodisulfonic Acid & $M G / L$ & .5 & 45.0 & $10 / 28 / 57$ & 1.0 \\
\hline & $i$ & & & & & i $1 / 09 / 58$ & 1.0 \\
\hline & i & & & & & $12 / 12 / 58$ & 1.0 \\
\hline & 1 & & & & & $3 / 11 / 58$ & 1.0 \\
\hline & 1 & & & & & | $4 / 09 / 58$ & 1.0 \\
\hline & i & & & & & 1 $5 / 07 / 58$ & 1.0 \\
\hline & i & & & & & $12 / 11 / 58$ & 1.0 \\
\hline & 1 & & & & & $3 / 01 / 59$ & 1.0 \\
\hline & i & & & & & $14 / 01 / 59$ & 1.0 \\
\hline & $i$ & & & & & i $7 / 01 / 59$ & 1.0 \\
\hline & 1 & & & & & $15 / 78 / 61$ & .1 \\
\hline & $i$ & & & & & | $8 / 17 / 61$ & .3 \\
\hline & $i$ & & & & & | $12 / 21 / 61$ & .1 \\
\hline & $i$ & & & & & $12 / 07 / 62$ & .1 \\
\hline & 1 & $\cdot$ & & & & i $8 / 02 / 62$ & 5.0 \\
\hline & 1 & . & & & & $18 / 05 / 63$ & .1 \\
\hline & 1 & & & & & $5 / 14 / 69$ & .2 \\
\hline & 1 & & & & & $7 / 17 / 69$ & 1.9 \\
\hline & 1 & & & & & | 10/28/69 & .5 \\
\hline & i & & & & & i $6 / 06 / 72$ & 4.3 \\
\hline & I & & & & & $4 / 02 / 73$ & 3.8 \\
\hline & 1 & & & & & $8 / 30 / 73$ & .5 \\
\hline & 1 & & & & & $1 \quad 2 / 28 / 74$ & 25.0 \\
\hline & i & & & & & $9 / 09 / 74$ & 17.0 \\
\hline & 1 & & & & & $11 / 03 / 75$ & .5 \\
\hline & 1 & & & & & i 5/01/75 & .5 \\
\hline & i & & & & & $7 / 01 / 75$ & .5 \\
\hline & 1 & & & & & | 11/04/75 & 3.7 \\
\hline & $i$ & & & & & i $1 / 05 / 76$ & .5 \\
\hline & 1 & & & & & $15 / 03 / 76$ & .5 \\
\hline & I & & & & & i $6 / 29 / 76$ & .5 \\
\hline & $i$ & & & & & | $10 / 26 / 76$ & .5 \\
\hline & i & & & & & 1 2/01/77 & .5 \\
\hline$\cdot$ & 1 & & & & & i $4 / 25 / 77$ & .5 \\
\hline & 1 & & & & & | $6 / 24 / 81$ & .5 \\
\hline & $i$ & & & & & | $12 / 30 / 81$ & 1.9 \\
\hline & 1 & Hitrate-1on & $M G / L$ & .5 & 45.0 & I $11 / 27 / 84$ & 32.0 \\
\hline & 1 & Mirrite & PPB & 1000.0 & 3300.0 & | $12 / 20 / 91$ & 200.0 \\
\hline
\end{tabular}

Figure 5A-5. Water Quality Data. (sheet 14 of 24) 
DOE/RL-92-39, Rev. 1 $12 / 15 / 94$

8/05/92

Geosciences Group PARADOX Database

Well Result Report

Page 15

HPADS Groundwater Data

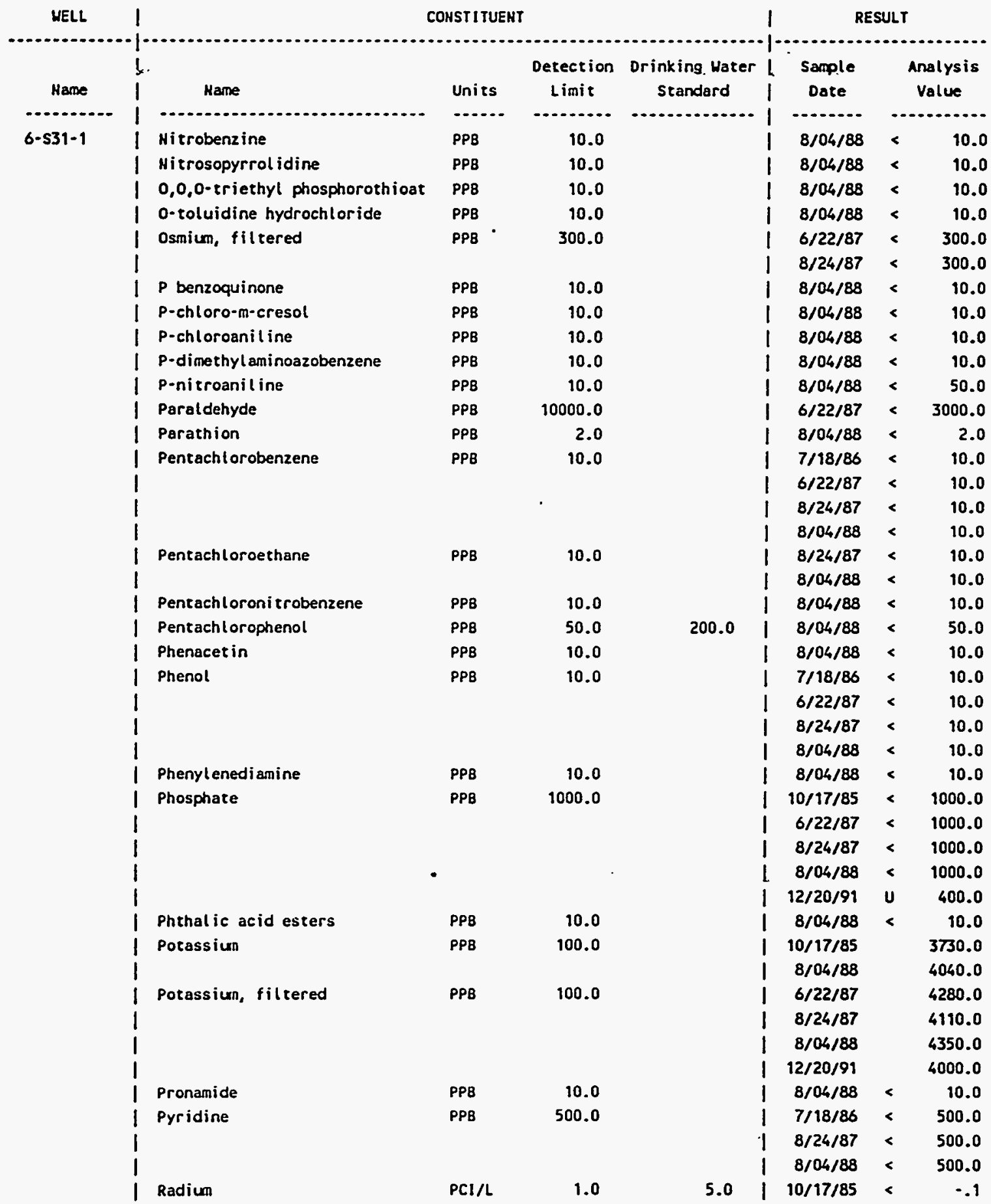

Figure 5A-5. Water Quality Data. (sheet 15 of 24) 
Well Result Report

HPADS Groundwater Data

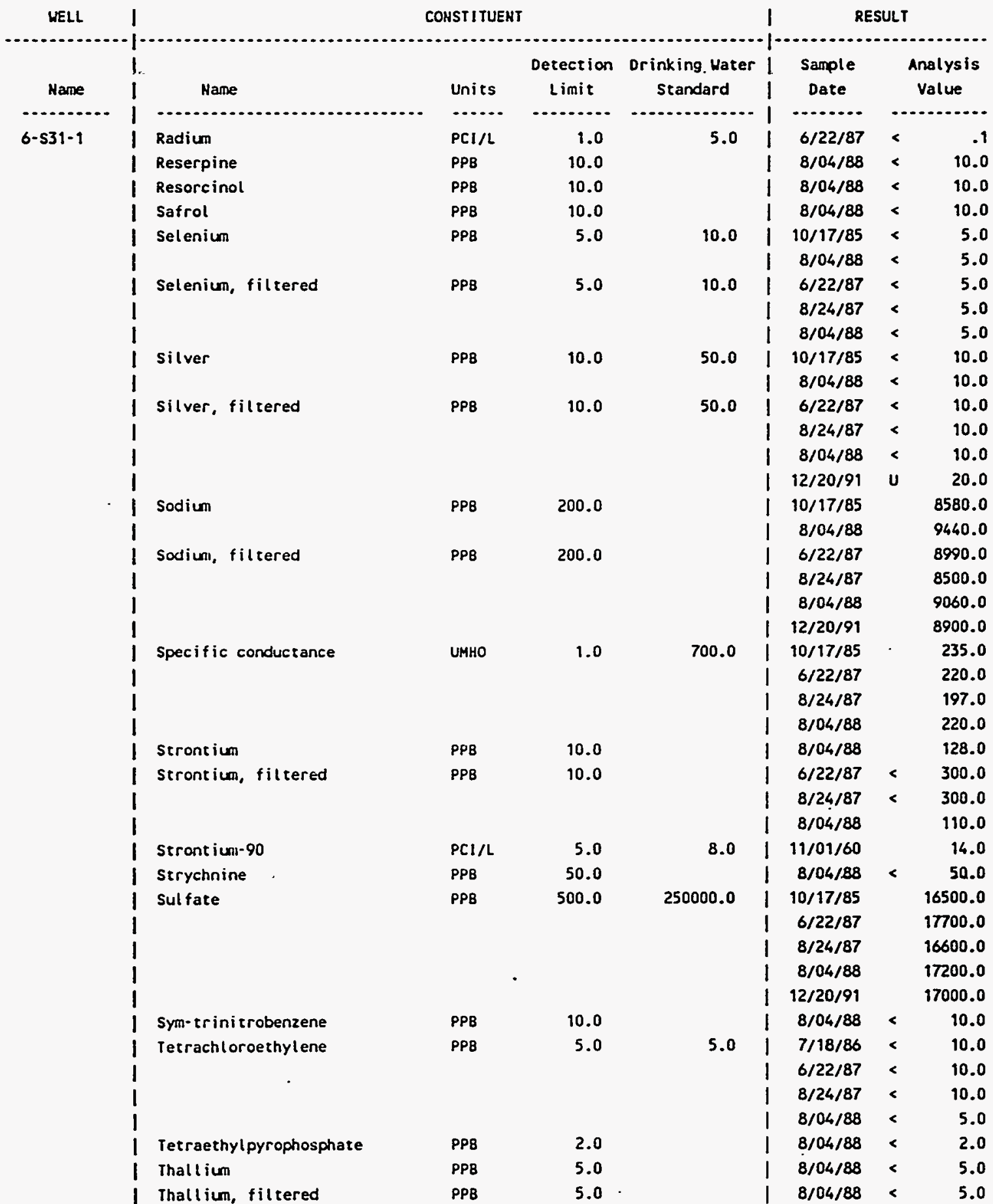

Figure 5A-5. Water Quality Data. (sheet 16 of 24) 
Well Result Report

HPADS Groundwater Data

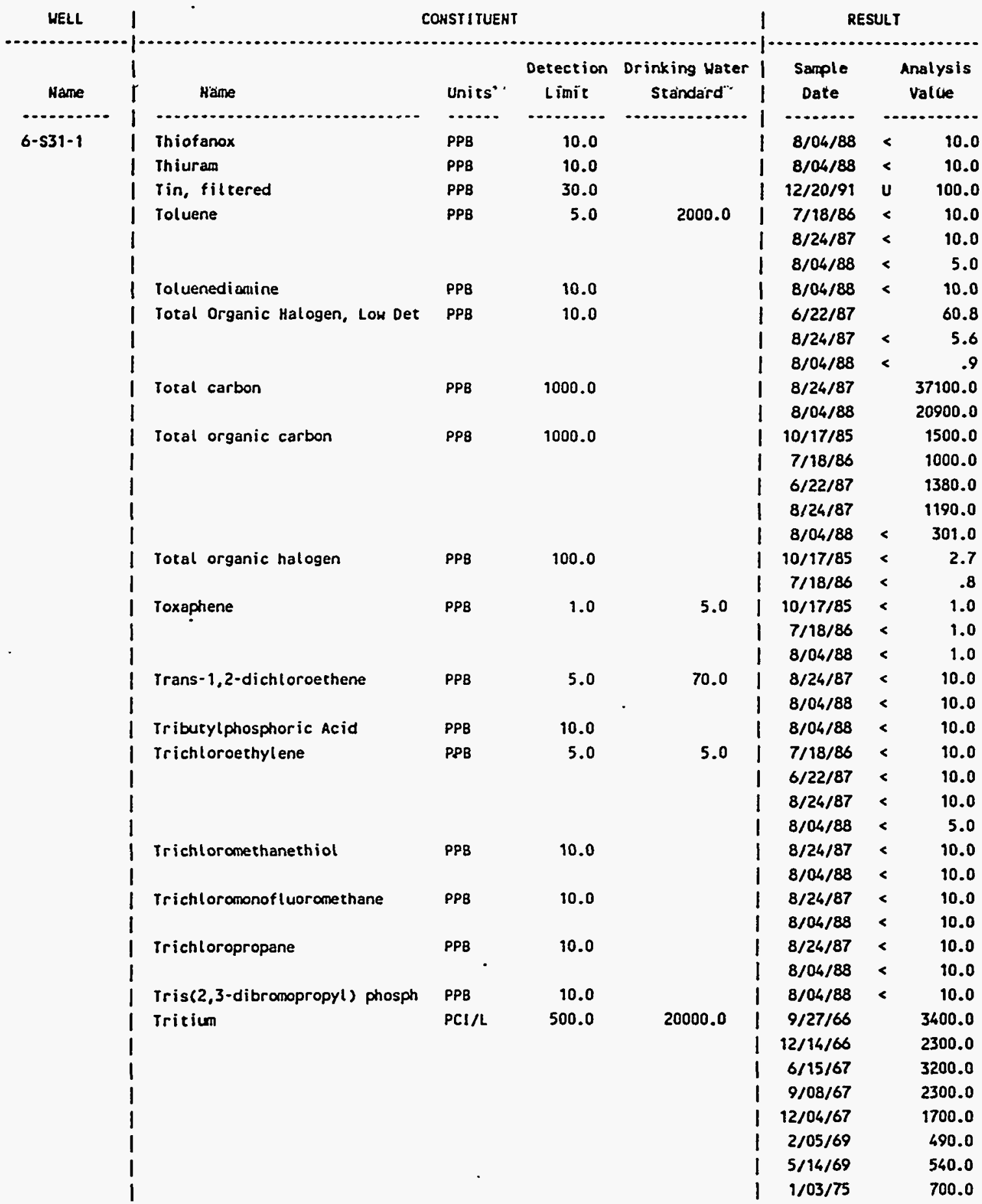

Figure 5A-5. Water Quality Data. (sheet 17 of 24) 


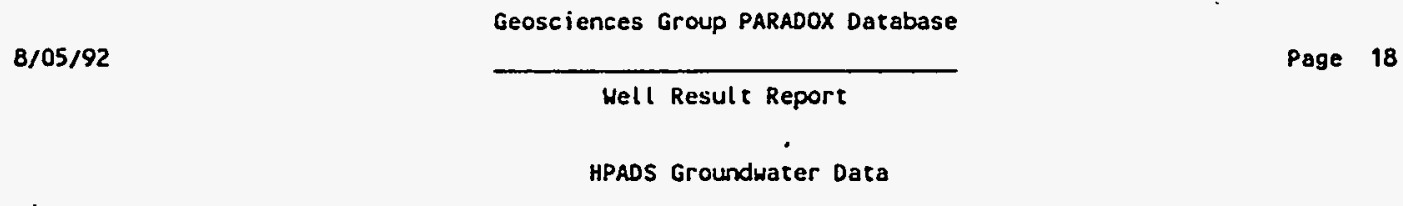

\begin{tabular}{|c|c|c|c|c|c|c|c|c|}
\hline WELL & 1 & \multicolumn{4}{|c|}{ CONSTITUENT } & \multicolumn{3}{|c|}{ RESULT } \\
\hline Hame & $i$ & Hame & Units & $\begin{array}{l}\text { Detection } \\
\text { Limit }\end{array}$ & $\begin{array}{c}\text { Drinking Woter } \\
\text { Standard }\end{array}$ & $\begin{array}{c}\text { Sample } \\
\text { Date }\end{array}$ & & $\begin{array}{l}\text { Anolysis } \\
\text { Value }\end{array}$ \\
\hline (n. & $\hat{j}$ & - & ..... & ......... & (n) & $\ldots \ldots$ & & $\ldots \ldots$ \\
\hline $6-531-1$ & i & Tritiun & $\mathrm{PCI} / \mathrm{L}$ & 500.0 & 20000.0 & $5 / 01 / 75$ & & 740.0 \\
\hline & i & & & & & $7 / 01 / 75$ & & 480.0 \\
\hline & i & & & & & $11 / 04 / 75$ & & 1100.0 \\
\hline & i & & & & & $11 / 05 / 76$ & & 950.0 \\
\hline & 1 & & & & & i 5/03/76 & & 900.0 \\
\hline & i & & & & & i $6 / 29 / 76$ & & 910.0 \\
\hline & i & & & & & $10 / 26 / 76$ & & 1100.0 \\
\hline & i & & & & & $2 / 01 / 77$ & & 570.0 \\
\hline & i & . & & & & $4 / 25 / 77$ & & 1500.0 \\
\hline & j & • & & & & $6 / 24 / 81$ & & 2400.0 \\
\hline & i & & & & & $12 / 30 / 81$ & & 710.0 \\
\hline & i & & & & & i $11 / 27 / 84$ & & 670.0 \\
\hline & i & & & & & $8 / 04 / 88$ & $<$ & -13.6 \\
\hline & 1 & & & & & $12 / 20 / 91$ & $u$ & -74.3 \\
\hline & I & Uranium, chemical & $U G / L$ & .7 & 59.0 & i $8 / 04 / 88$ & & 1.6 \\
\hline & i & Vanadium & PPB & 5.0 & & i 10/17/85 & & 12.0 \\
\hline & 1 & & & & & $8 / 04 / 88$ & & 7.0 \\
\hline & i & Vanadium, filtered & PPB & 5.0 & & $6 / 22 / 87$ & & 15.0 \\
\hline & i & & & & & $8 / 24 / 87$ & & 14.0 \\
\hline & 1 & & & & & 1 $8 / 04 / 88$ & $<$ & 5.0 \\
\hline & 1 & & & & & $12 / 20 / 91$ & $\mathbf{u}$ & 30.0 \\
\hline & i & Vinyl chloride & PPB & 10.0 & 2.0 & $8 / 24 / 87$ & $<$ & 10.0 \\
\hline & 1 & & & & & $8 / 04 / 88$ & $<$ & 10.0 \\
\hline & i & Warfarin & PPB & 10.0 & & $8 / 04 / 88$ & $<$ & 10.0 \\
\hline & i & xylene-m & PPB & 5.0 & 10000.0 & $7 / 18 / 86$ & $<$ & 10.0 \\
\hline & 1 & & & & & $6 / 22 / 87$ & $<$ & 10.0 \\
\hline & i & & & & & $8 / 24 / 87$ & $<$ & 10.0 \\
\hline & i & & & & & $8 / 04 / 88$ & $<$ & 5.0 \\
\hline & 1 & xylene-o,p & PPB & 5.0 & 10000.0 & $7 / 18 / 86$ & $<$ & 10.0 \\
\hline & i & & & & & $6 / 22 / 87$ & $<$ & 10.0 \\
\hline & i & & & & & $8 / 24 / 87$ & $<$ & 10.0 \\
\hline & 1 & & & & & $8 / 04 / 88$ & $<$ & 5.0 \\
\hline & 1 & Zine & PPB & 5.0 & 5000.0 & $8 / 04 / 88$ & $<$ & -5.0 \\
\hline & i & Zine, filtered & PPB & 5.0 & 5000.0 & $6 / 22 / 87$ & $<$ & 5.0 \\
\hline & 1 & & & & & $8 / 24 / 87$ & $<$ & 5.0 \\
\hline & 1 & & & & & $8 / 04 / 88$ & $<$ & 5.0 \\
\hline & i & & & & & | $12 / 20 / 91$ & $u$ & 10.0 \\
\hline & 1 & p-Dichtorobenzene & PPB & 10.0 & 750.0 & $7 / 18 / 86$ & $<$ & 10.0 \\
\hline & i & & & & & $6 / 22 / 87$ & $<$ & 10.0 \\
\hline & $i$ & & & & & $8 / 24 / 87$ & $<$ & 10.0 \\
\hline & 1 & & & & & $8 / 04 / 88$ & $<$ & 10.0 \\
\hline & i & p-Nitrophenol & PPB & 10.0 & & $8 / 04 / 88$ & $<$ & 50.0 \\
\hline & 1 & pH, Field Measurement & & .1 & 8.5 & $10 / 17 / 85$ & & 7.7 \\
\hline & 1 & & & & & $6 / 22 / 87$ & & 7.3 \\
\hline
\end{tabular}

Figure 5A-5. Water Quality Data. (sheet 18 of 24) 
Hell Result Report

MPADS Groundwater Data

\begin{tabular}{|c|c|c|c|c|c|c|c|c|}
\hline HELL & .1 & & INSTITUEH & & & 1 & ULT & \\
\hline & i & & & Detection & Drinking Water & Sample & & Analysis \\
\hline Hane & L. & Nane & Units & Limit & Standard & Date & & Value \\
\hline$\ldots \ldots$ & I & 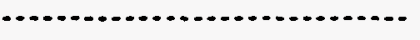 & $\cdots$ & -............ & $\ldots+\ldots \ldots+\ldots$ & $1 \quad \cdots \ldots$ & & ....... \\
\hline $6-531-1$ & 1 & pH, field Measurement- & - & .1 & 8.5 & $8 / 24 / 87$ & & 7.3 \\
\hline & I & & & & & $8 / 04 / 88$ & & 7.7 \\
\hline & I & pH, Laboratory Measurement & & .0 & 8.5 & $6 / 22 / 87$ & & 7.8 \\
\hline & 1 & & & & & $8 / 24 / 87$ & & 7.9 \\
\hline & I & & & & & $18 / 04 / 88$ & & 8.1 \\
\hline & 1 & & & & & I $12 / 20 / 91$ & & 8.0 \\
\hline & 1 & & & & & 1 & & \\
\hline $6-531-1 P$ & 1 & $1,1,1-$ trichloroethane & PPB & 5.0 & 200.0 & $5 / 14 / 90$ & $<$ & 5.0 \\
\hline & I & 1,1,2-trichloroethane & PPB & 5.0 & & $5 / 14 / 90$ & $<$ & 5.0 \\
\hline & 1 & 1,1-dichloroethane & PPB & 5.0 & & I $5 / 14 / 90$ & $<$ & 5.0 \\
\hline & 1 & 1,2-dichloroethane & PPB & 5.0 & 5.0 & $5 / 14 / 90$ & $<$ & 5.0 \\
\hline & 1 & Acetone by VOA & PPB & 10.0 & & $5 / 14 / 90$ & $<$ & 10.0 \\
\hline & 1 & Benzene & PPB & 5.0 & 5.0 & $5 / 14 / 90$ & $<$ & 5.0 \\
\hline & 1 & Bicarbonate & $M G / L$ & 1.0 & & $2 / 01 / 77$ & & 180.0 \\
\hline & 1 & & & & & $12 / 04 / 78$ & & 150.0 \\
\hline & 1 & & & & & | 12/01/80 & & 130.0 \\
\hline & 1 & & & & & $1 \quad 1 / 03 / 83$ & & 70.0 \\
\hline & 1 & & & & & $112 / 12 / 83$ & & 82.0 \\
\hline & 1 & Boron (Colorimetric by curcuni & UG/L & .0 & & $2 / 01 / 77$ & & .1 \\
\hline & I & & & & & | 12/01/80 & & .2 \\
\hline & 1 & & & & & $1 / 03 / 83$ & & .1 \\
\hline & 1 & & & & & $12 / 12 / 83$ & & .2 \\
\hline & 1 & Carbon Ietrachloride by GC/MS & PPB & 5.0 & 5.0 & $5 / 14 / 90$ & $<$ & 5.0 \\
\hline & 1 & Carbonate & MG/L & 1.0 & & $2 / 01 / 77$ & & 0.0 \\
\hline & 1 & & & & & | $12 / 04 / 78$ & & 2.5 \\
\hline & 1 & & & & & | 12/01/80 & & 1.8 \\
\hline & 1 & & & & & $1 / 03 / 83$ & & 1.3 \\
\hline & 1 & & & & & | $12 / 12 / 83$ & & 1.6 \\
\hline & 1 & Chemical calciun by $A A$ & $M G / L$ & .5 & & $2 / 01 / 77$ & & 26.0 \\
\hline & 1 & & & & & | $12 / 04 / 78$ & & 35.0 \\
\hline & 1 & & & & & I 12/01/80 & & 22.0 \\
\hline & 1 & $\bullet$ & & & & $1 / 03 / 83$ & & 30.0 \\
\hline & 1 & & & & & | 12/12/83 & & 25.0 \\
\hline & 1 & Cherrical sadiun by $A A$ & MG/L & 1.0 & & $2 / 01 / 77$ & & 31.0 \\
\hline & i & & & & & $12 / 04 / 78$ & & 33.0 \\
\hline & 1 & & & & & $112 / 01 / 80$ & & 32.0 \\
\hline & 1 & & & & & $1 / 03 / 83$ & & 9.3 \\
\hline & 1 & & & & & | 12/12/83 & & 7.6 \\
\hline & I & Chloride by chenical analysis & $M G / L$ & .1 & 250.0 & I 2/01/77 & & 4.3 \\
\hline & 1 & & & & & I $12 / 04 / 78$ & & 13.0 \\
\hline & i & & & & & I 12/01/80 & & 4.8 \\
\hline & I & & & & & $1 / 1 / 03 / 83$ & & 6.0 \\
\hline & 1 & & & & & | $12 / 12 / 83$ & & 4.9 \\
\hline & i & Chloroforin & PPB & 5.0 & 100.0 & | $5 / 14 / 90$ & $<$ & 5.0 \\
\hline
\end{tabular}

Figure 5A-5. Hater Quality Data. (sheet 19 of 24) 


8/05/92
$\frac{\text { Geosciences Group PARADOX Database }}{\text { Hell Result Report }}$
HPAOS Groundwater Data

\begin{tabular}{|c|c|c|c|c|c|c|c|}
\hline WELL & I & & DNSTI TUE! & & & 1 & SULT \\
\hline Hane & 1 & Hame & Units & $\begin{array}{l}\text { Detection } \\
\text { Limit }\end{array}$ & $\begin{array}{l}\text { Drinking Hater } \\
\text { Standard }\end{array}$ & Sample & Analysis \\
\hline & 1 & 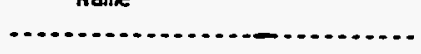 & ........ & $\begin{array}{c}\text { Limit } \\
. . . . . . . . .\end{array}$ & $\begin{array}{l}\text { Standard } \\
\ldots . . . . . . . . . . . .\end{array}$ & & \\
\hline $6-531-1 P$ & 1 & Gross alpha & $\mathrm{PCI} / \mathrm{L}$ & 4.0 & 15.0 & i $2 / 19 / 88$ & 1.2 \\
\hline & I & & & & & $8 / 04 / 88$ & .9 \\
\hline & 1 & & & & & $1 / 20 / 89$ & .6 \\
\hline & 1 & Gross beta & $\mathrm{PCl} / \mathrm{L}$ & 8.0 & 50.0 & $1 / 25 / 67$ & 220.0 \\
\hline & 1 & & & & & $12 / 15 / 67$ & 880.0 \\
\hline & 1 & & & & & $13 / 21 / 67$ & 19000.0 \\
\hline & 1 & & & & & $4 / 11 / 67$ & 150.0 \\
\hline & ! & & & & & $15 / 03 / 67$ & 6000.0 \\
\hline & I & & & & & $16 / 15 / 67$ & 270.0 \\
\hline & I & & & & & $17 / 12 / 67$ & 140.0 \\
\hline & 1 & & & & & $110 / 03 / 67$ & 160.0 \\
\hline & I & & & & & $110 / 30 / 67$ & 480.0 \\
\hline & 1 & & & & & I $12 / 04 / 67$ & 140.0 \\
\hline & ! & & & & & $12 / 05 / 68$ & 4.0 \\
\hline & 1 & & & & & $13 / 04 / 68$ & 43.0 \\
\hline & I & & & & & $13 / 08 / 68$ & 110.0 \\
\hline & 1 & & & & & $13 / 26 / 68$ & 13.0 \\
\hline & 1 & & & & & $15 / 06 / 68$ & 7.0 \\
\hline & I & & & & & $16 / 05 / 68$ & 450.0 \\
\hline & 1 & & & & & $16 / 12 / 68$ & 150.0 \\
\hline & 1 & & & & & $17 / 19 / 68$ & 110.0 \\
\hline & 1 & & & & & $18 / 05 / 68$ & 74.0 \\
\hline & 1 & & & & & | $9 / 17 / 68$ & 46.0 \\
\hline & 1 & & & & & $19 / 30 / 68$ & 170.0 \\
\hline & 1 & & & & & I 11/04/68 & 150.0 \\
\hline & 1 & & & & & $1 \quad 12 / 16 / 68$ & 150.0 \\
\hline & 1 & & & & & $11 / 28 / 69$ & 160.0 \\
\hline & 1 & & & & . & $1 \quad 2 / 05 / 69$ & 150.0 \\
\hline & 1 & & & & & $1 \quad 3 / 03 / 69$ & 180.0 \\
\hline & 1 & & & & & 1 4/15/69 & 150.0 \\
\hline & 1 & & & & & I 5/14/69 & 150.0 \\
\hline & 1 & & & & & $16 / 03 / 69$ & 150.0 \\
\hline & 1 & & & & & | 7/17/69 & 150.0 \\
\hline & 1 & & & & & $17 / 28 / 69$ & 160.0 \\
\hline & 1 & & & & & | 10/28/69 & 150.0 \\
\hline & 1 & & & & & | $2 / 19 / 88$ & 4.4 \\
\hline & 1 & & & & & | $8 / 04 / 88$ & 3.7 \\
\hline & 1 & & & & & 1 $1 / 20 / 89$ & 1.3 \\
\hline & I & Hardness & $M G / L$ & & & | 1/03/83 & 83.0 \\
\hline & I & Magnesium by chemical analysis & $M G / L$ & .3 & & | $2 / 01 / 77$ & 9.3 \\
\hline & 1 & & & & & $1 \quad 12 / 04 / 78$ & 10.0 \\
\hline & I & & & & & | 12/01/80 & 9.3 \\
\hline & I & & & & & | 1/03/83 & 6.9 \\
\hline & 1 & & & & & | 12/12/83 & 7.6 \\
\hline
\end{tabular}

Figure 5A-5. Water Quality Data. (sheet 20 of 24) 
$8 / 05 / 92$

Geosciences Group PARADOX Database

Hell Result Report

Page 21

HPADS Groundwater Data

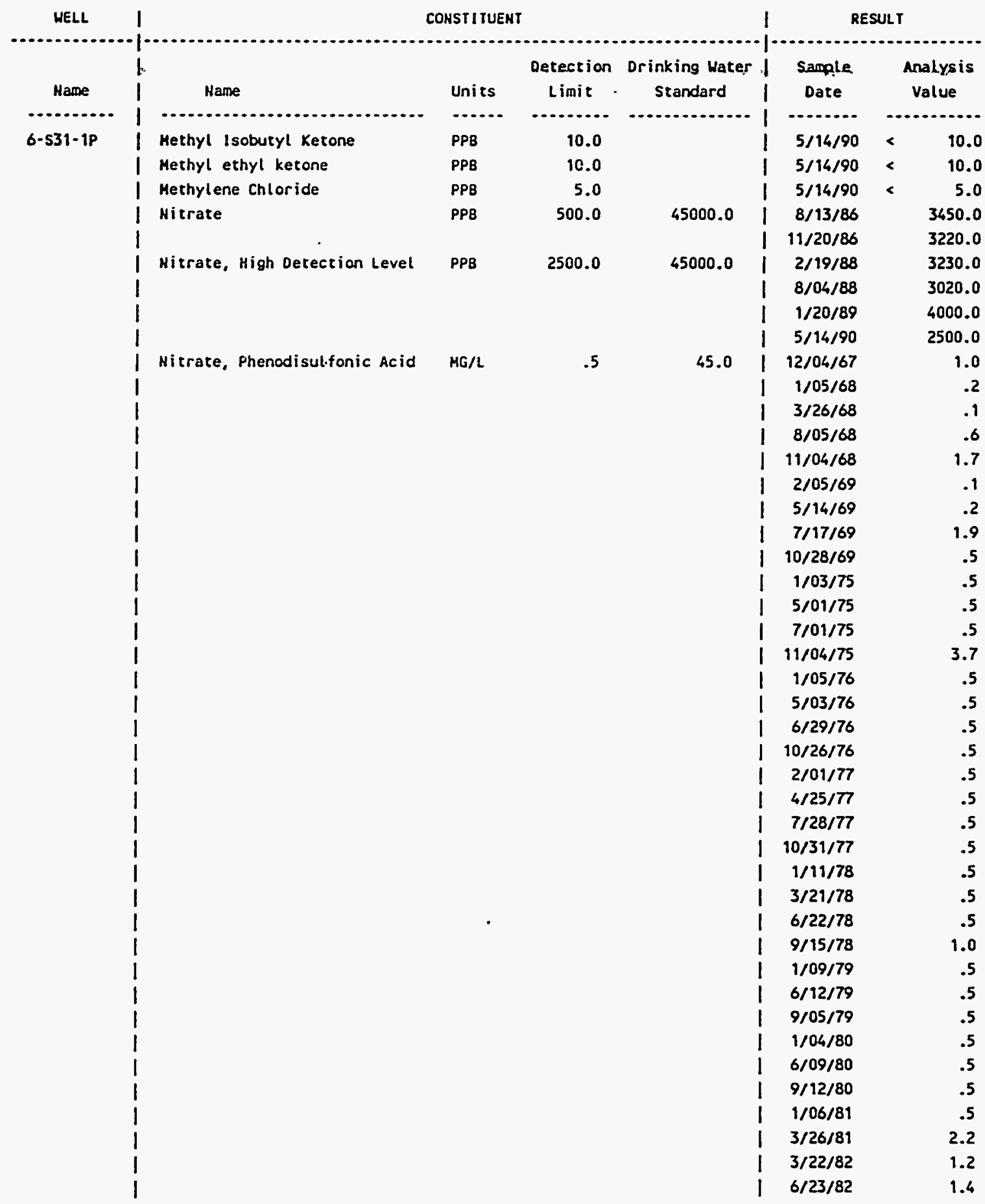

Figure 5A-5. Water Quality Data. (sheet 21 of 24) 
DOE/RL-92-39, Rev. 1

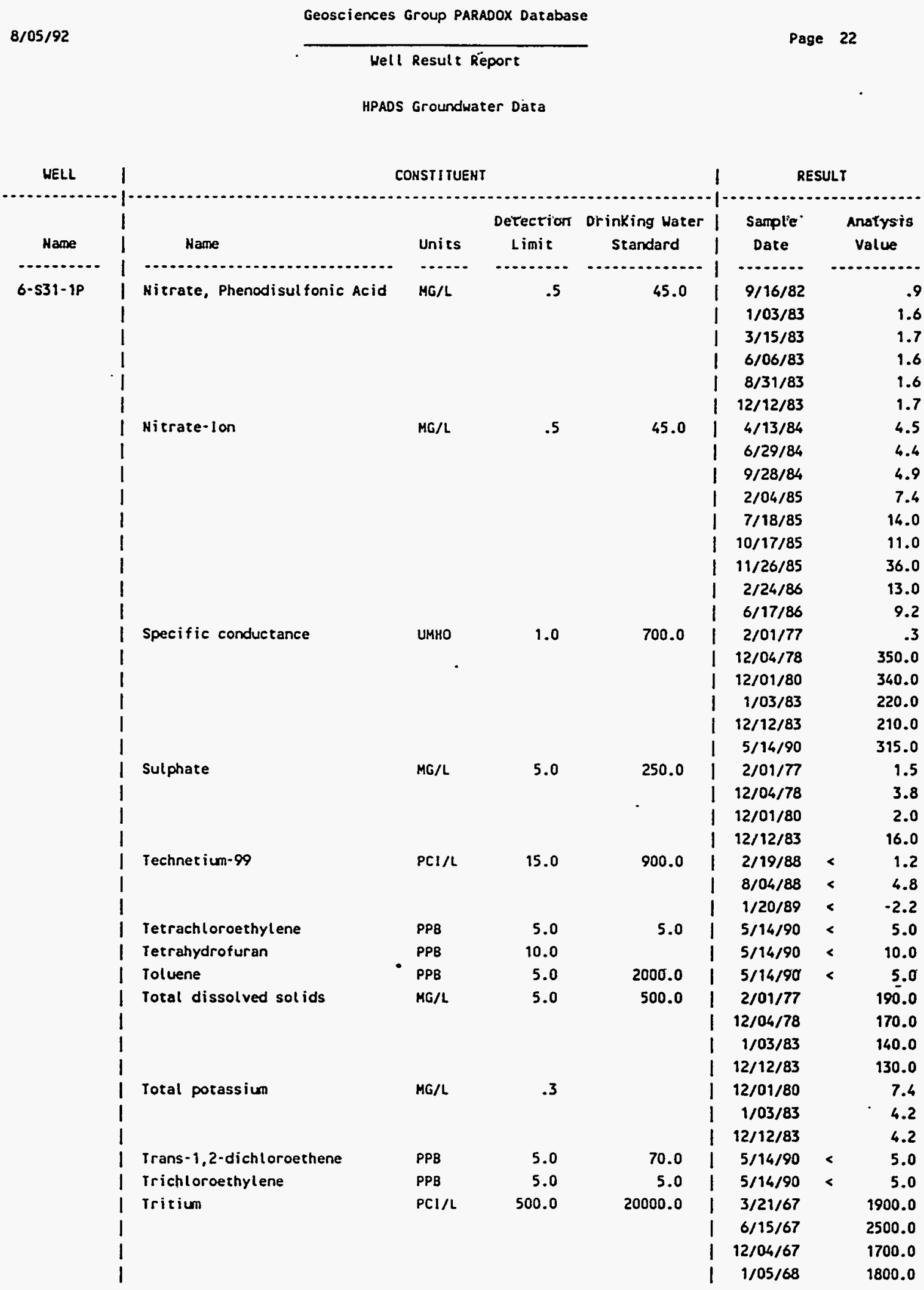

Figure 5A-5. Water Quality Data. (sheet 22 of 24) 


8/05/92 $\frac{\text { Geosciences Group PARADOX Database }}{\text { Hell Result Ręport }}$
HPADS Groundwater Data 23

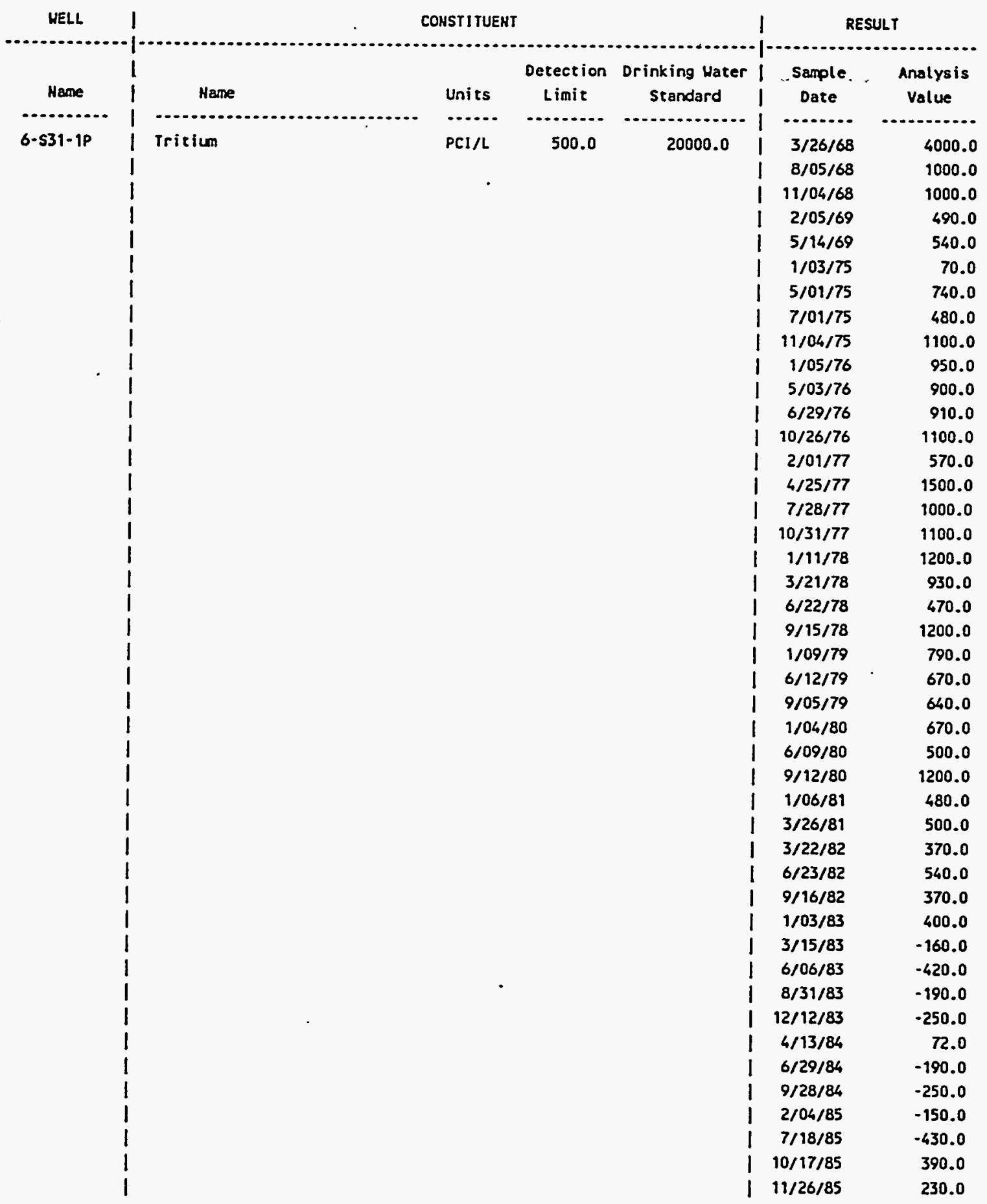

Figure 5A-5. Water Quality Data. (sheet 23 of 24) 
$8 / 05 / 92$

Geosciences Group PARADOX Database

Well Result Report

Page 24

HPADS Groundwater. Data

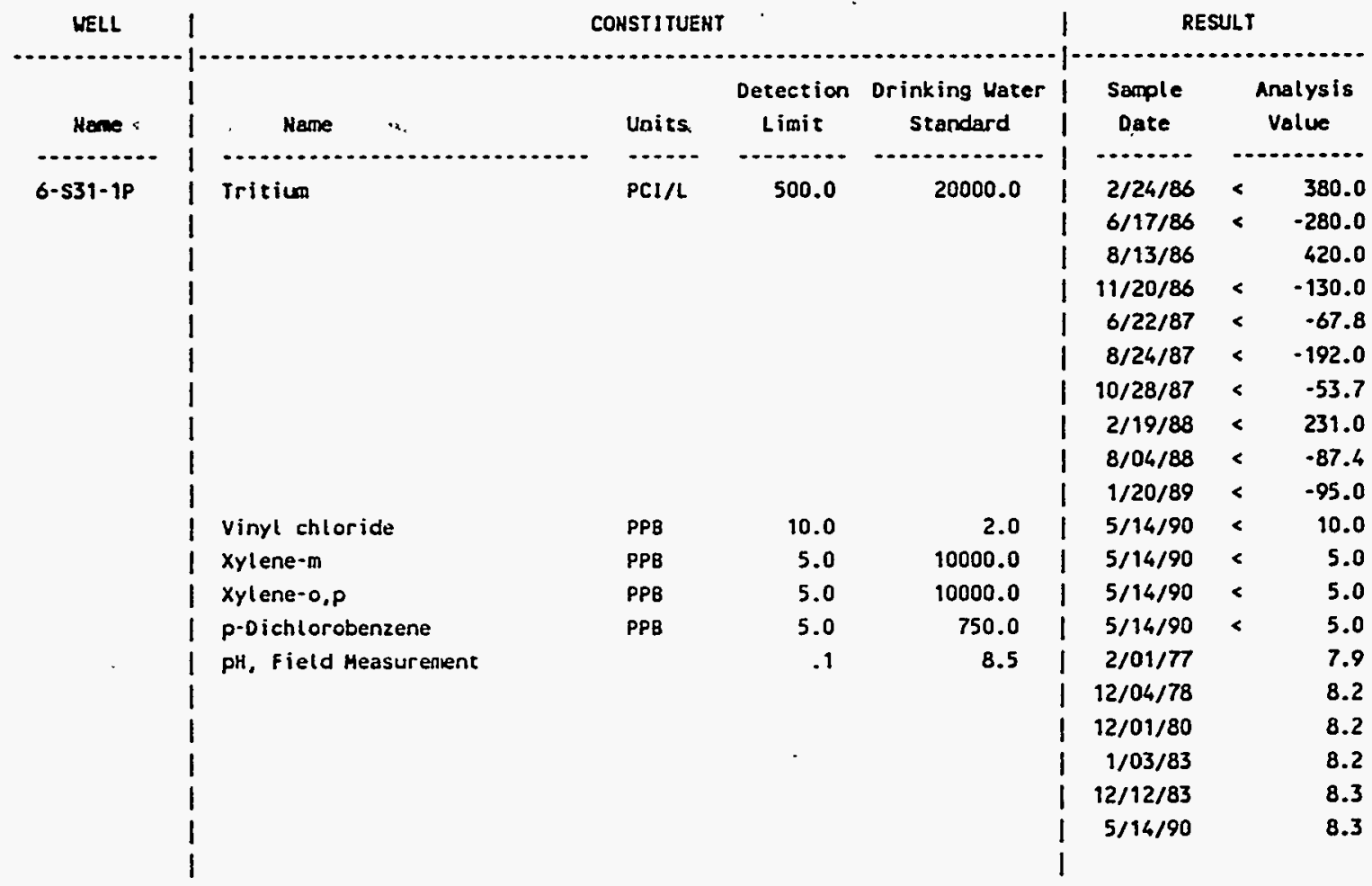

Figure 5A-5. Water Quality Data. (sheet 24 of 24) 


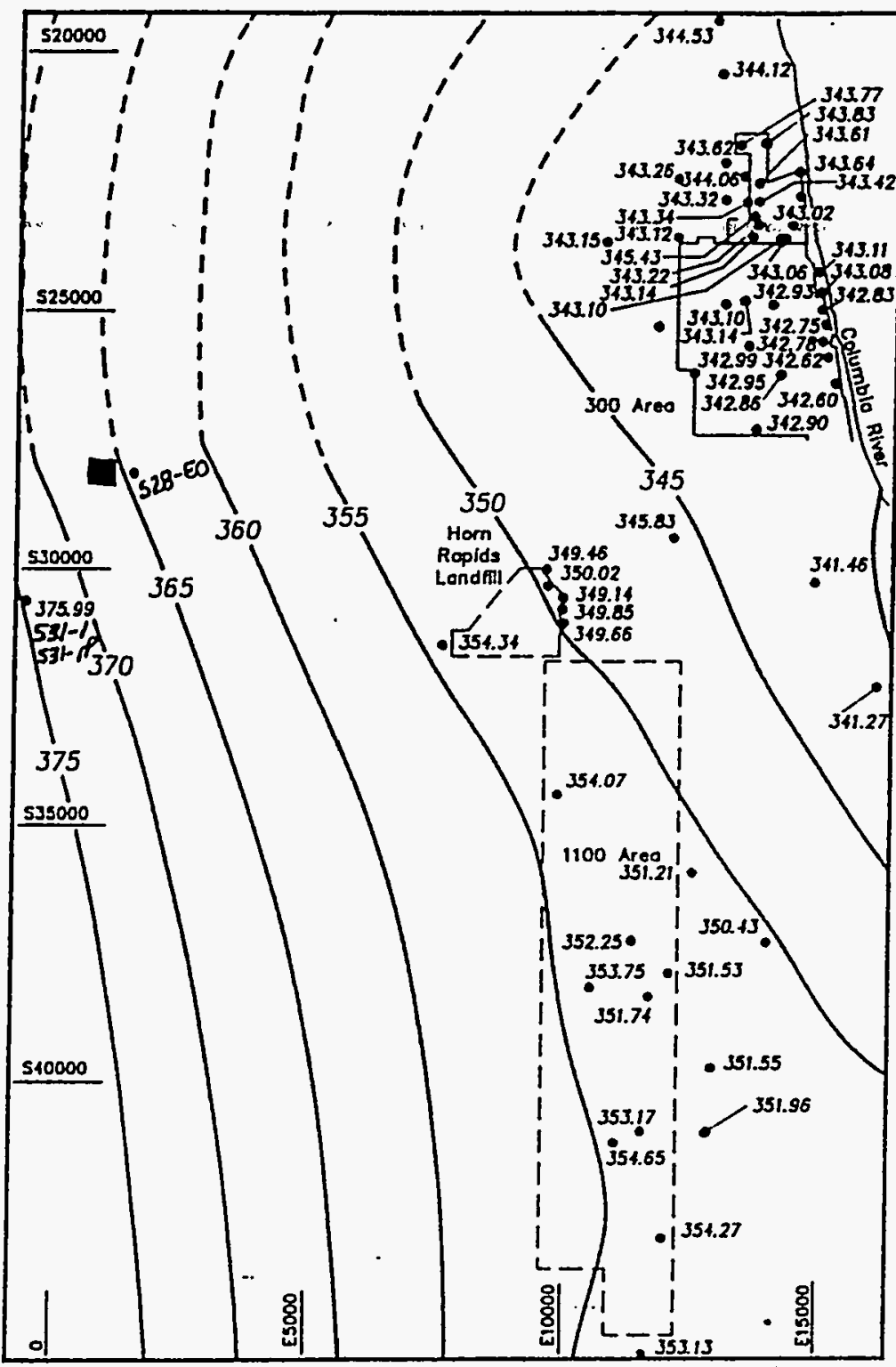

\section{$300 / 1100$ Area \\ Water Table Map \\ December 1991}

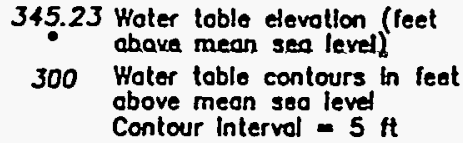

345.23 Woter toble elevotion (feet abave mean sea level)

300 Woter toble contours in leet above mean seo level

Contour Interval $=5 \mathrm{ft}$

The 300 Area water toble mop hos been prepored by the Geosciences Group. Envisonmentol bivision, of Westinghouse Honford Compony.

Note: To convert to metric, multiply elavation (ft) by 0.3048 to obtoin devotion (m).

From; Kaszo. et al. 1991

Hanforo PATROL ACADGMY

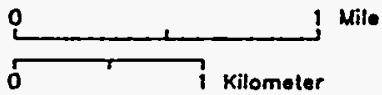

Figure 5A-6. Water Table Map. 
DOE/RL-92-39, Rev. 1

$12 / 15 / 94$

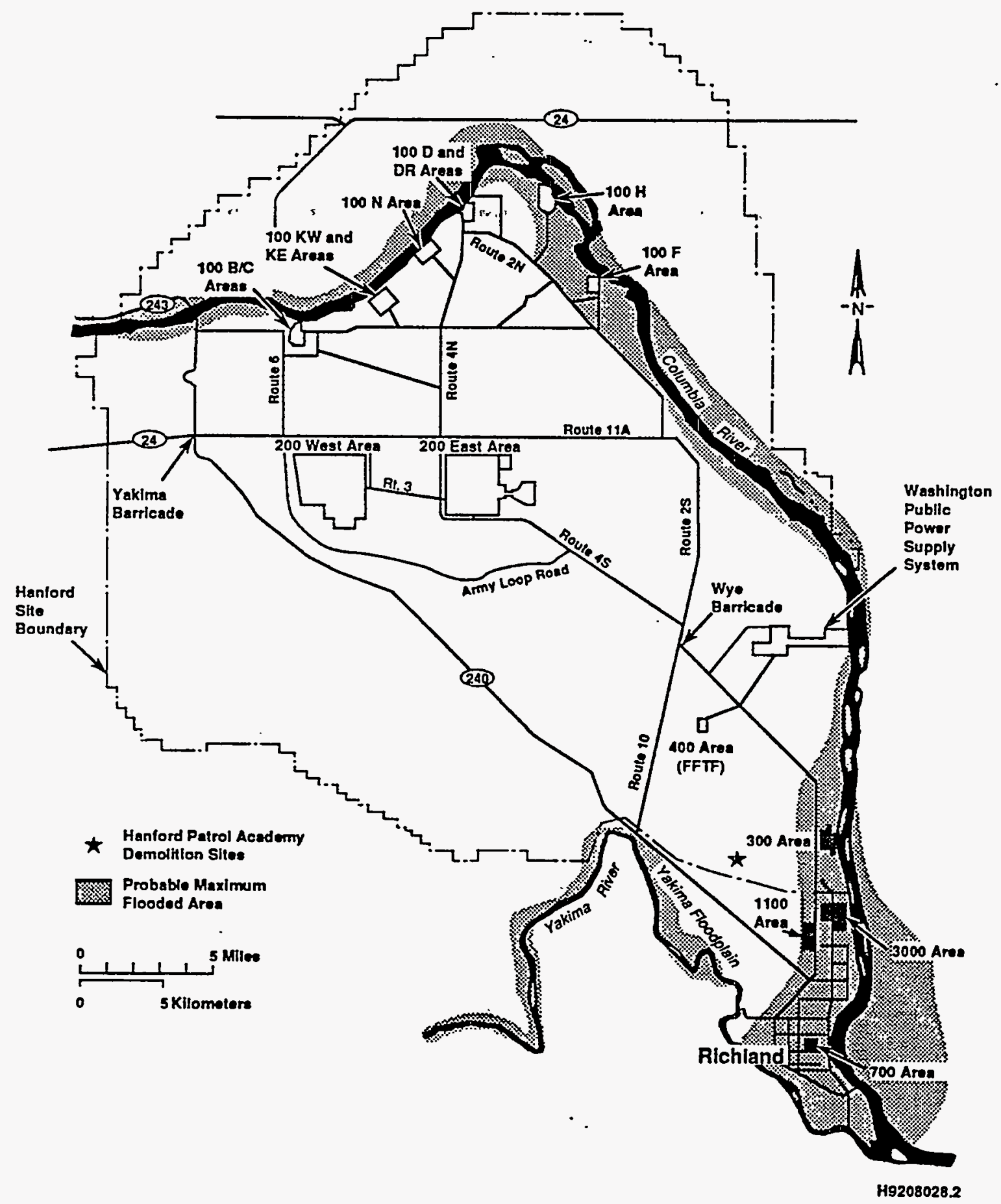

Figure 5A-7. 100-Year Flood Event. 
- APPENDIX 7A

QUALITY ASSURANCE PROJECT PLAN FOR SOIL SAMPLING MD MULYSIS FOR THE HANFORD PATROL ACADEMY DEHOLITION SITES 
DOE/RL-92-39, Rev. 1

$12 / 15 / 94$

This page intentionally left blank.

APP 7A- $\mathbf{j}$ 
CONTENTS

7A.0 QUALITY ASSURANCE PROJECT PLAN FOR SOIL SAMPLING AND

ANALYSIS FOR THE HANFORD PATROL ACADEMY DEMOLITION

SITES ................................ APP $7 A-1$

7A.1 PROJECT DESCRIPTION ............ APP 7A-1

7A.1.1 Project Objectives . . . . . APP 7A-1

7.A.1.2. Applicability and Relationship to the Onsite Contractor's Quality Assurance

Program ................. APP 7A-1

7A.2 PROJECT ORGANIZATION AND RESPONSIBILITIES ..... APP 7A-2

7A.2.1 Project Management Responsibilities .... APP 7A-2

7A.2.2 Analytical Laboratories ......... APP 7A-3

7A.2.3 Other Support Contractors ........ APP 7A-3

7A.3 DATA QUALITY OBJECTIVES FOR MEASUREMENTS . . . . A APP 7A-3

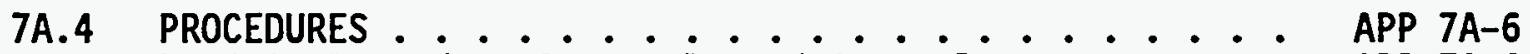

7A.4.1 Procedure Approvals and Controls . . . APP 7A-6

7A.4.1.1 Hanford Site Procedures ..... APP 7A-6

7A.4.1.2 Participating Contractor and/or

Subcontractor Procedures ..... APP 7A-6

7A.4.2 Sampling Procedures ......... APP 7A-7

7A.4.3 Procedure Additions and Changes ..... APP 7A-7

$7 A .5$ SAMPLE CUSTODY ...................... APP 7A-7

7A.6 CALIBRATION PROCEDURES ..................... APP 7A-8

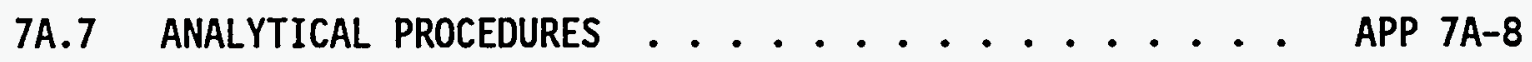

7A.8 DATA REDUCTION, VALIDATION, AND REPORTING . . . A APP 7A-8

7A.8.1 Data Reduction and Data Package

Preparation ............. APP 7A-8

7A.8.2 Validation ...................... APP 7A-9

7A.8.3 Final Review and Records Management................... 7 CA-11

7A.9 INTERNAL QUALITY CONTROL . . . . . . . APP 7A-11

7A.10 PERFORMANCE AND SYSTEM AUDITS ......... APP 7A-12

7A.11 PREVENTIVE MAINTENANCE . . . . . . . . APP 7A-13

7 A.12 DATA ASSESSMENT . . . . . . . . APP 7A-13

7A.13 CORRECTIVE ACTION ....................... 7A-13

7A.14 QUALITY ASSURANCE REPORTS . . . . . . A APP 7A-14 
DOE/RL-92-39, Rev. 1

$12 / 15 / 94$

This page intentionally left blank. 


\section{A.0 QUALITY ASSURANCE PROJECT PLAN FOR SOIL SAMPLING AND ANALYSIS FOR THE HANFORD PATROL ACADEMY DEMOLITION SITES}

This appendix provides the quality assurance and quality control information to ensure that HPADS closure activities (Chapter 7.0 ) provide suitable closure data.

\section{A.1 PROJECT DESCRIPTION}

This quality assurance project plan (QAPjP) has been prepared for regulatory review with the HPADS closure plan in support of proposed sampling and analysis activities.

Between August 1983 and October 1991, discarded explosive chemical products, consisting predominantly of organic compounds and metal salts, were demolished at the HPADS. This treatment unit will undergo closure consistent with WAC 173-303 regulations. One or more rounds of soil sampling and analysis are proposed in the closure plan (Chapter 7.0) to identify and characterize soil contaminants of concern at the site.

\section{A.1.1 Project Objectives}

The principal objective of Phase I investigative sampling will be for RCRA clean closure of the site by verifying that the concentration of all contaminants associated with operation of the TSD are at or below action levels. Action levels are defined as levels above the Hanford Site soil background and MTCA Method B levels. If soil contaminants are discovered above action levels, a Phase II sampling will be initiated. Twenty-nine samples were collected in closure areas \#1 and \#2. The samples will be analyzed at an offsite contract laboratory.

If any soil is removed from the HPADS to facilitate closure, an additional round of sampling and analys is (verification sampling) would be performed to demonstrate that soil removal objectives had been achieved (i.e., that residual contamination levels were below the proposed cleanup values).

\section{A.1.2 Applicability and Relationship to the Onsite Contractor's Quality Assurance Program}

This QAPjP applies specifically to field activities and laboratory analyses to be performed in support of closure of HPADS. This QAPjP has been prepared in compliance with the Environmental Engineering, Geotechnology, and Permitting Function Quality Assurance Program Plan (WHC 1990a) and Interim Guidelines for Preparing Quality Assurance Project Plans (EPA 1980). This QAPjP describes the means selected to implement quality assurance program requirements, defined in the Quality Assurance Manual (WHC 1988b), as the requirements apply to environmental investigations, while accommodating the specific requirements for project $p$ lan format and content agreed on in the 
Tri-Party Agreement. The project plan contains a matrix of procedural resources from Environmental Engineering, Geotechnology, and Permitting Function Quality Assurance Program Plan (WHC 1990a) and Environmental Investigations and Site Characterization Maniual (WHC 1988a). This QAPjP is subject to mandatory review and revision in advance of initiation of field sampling activities. Distribution and revision control of this pian will be carried out in compliance with QR 6.0, "Document Control," and QI 6.1, "Quality Assurance Document Control" (WHC 1988b). All plans and procedures referenced in this QAPJP are available for regulatory review.

\section{A.2 PROJECT ORGANIZATION AND RESPONSIBILITIES}

Organization responsibilities are discussed in the following sections.

\section{A.2.1 Project Management Responsibilities}

The operations contractor's Regulatory Support organization and the Environmental Restoration Engineering Function have primary responsibilities for conducting this investigation. An organizational chart is included as Figure 7A-1. The responsibilities of key test personnel and organizations are described in the following.

- Dangerous Waste Closure Plan Lead (Regulatory Support Organization)-The Dangerous Waste Closure Plan Lead is responsible for the overal1 organization of the closure plan and will interface with the regulatory agencies and the U.S. Department of Energy.

- Technical Lead--The Technical Lead is responsible for overall direction of sampling and testing activities; responsibilities include the $p 1$ anning and authorization of all work and management of any subcontracted activities, as well as overall technical schedule and budgetary performance.

- Quality Assurance Officer--The Quality Assurance Officer is responsible for coordination and/or oversight of performance to the QAPjP requirements by means of internal auditing and surveillance techniques. The Quality Assurance Officer retains the necessary organizational independence and authority to" identify conditions adverse to quality and to inform the Technical Lead of needs for corrective action.

- Health and Safety Officer (Environmental Division/Environmental Field Services)--The Health and Safety Officer is responsible for determining potential health and safety hazards from volatile and/or toxic compounds during sample handling and sampling decontamination activities. The Health and Safety Officer has the responsibility and authority to halt field activities because of unacceptable health and safety concerns. 
- Health Physics Technician--The health physics technician is responsible for ensuring that all monitoring and protection procedures are being followed as required in the dangerous waste operations plan. The health physics technician has the authority to take whatever steps might be necessary to carry out this function.

- Field Team Leader--The Field Team Leader is responsible for onsite direction of sampling technicians in compliance with the requirements of the sampling plan (Chapter 7.0, Section 7.2), this QAPJP, and implementing alt ELIs.

- Sample Management Organization--The sample management organization is responsible for procurement and coordination of analytical support services, sample tracking through the laboratories, and receipt and validation of analytical data as discussed in Section 7A.8.

\section{A.2.2 Analytical Laboratories}

The field sampling team will be responsible for screening all samples for gross alpha and beta/gamma radioactivity and for separating samples for further analysis. Samples with levels exceeding 200 picocuries per gram (total activity) or 60 picocuries per gram (alpha) will be routed to a Hanford Site or participating contractor laboratory qualified to handle analysis of radioactive samples. Samples exceeding 200 picocuries per gram (total activity) or 60 picocuries per gram (alpha) are not expected for this investigation. Samples with lower levels of radioactivity will be routed in accordance with the procedures identified below for chemical samples.

Samples will be routed to an offsite contract laboratory, who will be responsible for performing the analyses identified in the sampling and analysis pian in Appendix $7 C$.

\section{A.2.3 Other Support Contractors}

Support contractors could be assigned project responsibilities at the direction of the Technical Lead. Such services will be in compliance with standard Hanford Site procurement procedure requirements as discussed in Section 7A.4.1.2. All work will be performed in compliance with approved quality assurance plans and/or procedures, subject to controls of QI 7.3, "Source Surveillance and Inspection" (WHC 1988b).

\section{A.3 DATA QUALITY OBJECTIVES FOR MEASURENENTS}

Data quality objectives for a given data collection activity describe the overall level of uncertainty that decision makers are prepared to accept in the analytical results deriving from the activity. The agreements from the DQO process are summarized in the SAP (Appendix 7C). Data quality requirements generally are defined in terms of specific objectives for 
1 precision, accuracy, representativeness, comparability, and completeness. 2 Objectives for soil sampling at HPADS Closure Areas \#1 and \#2 are described in 3 this section.

Precision typically is calculated either as a range $(R)$ (for duplicate measurements) or a standard deviation $(\sigma)$. Precision al so can be expressed as a relative range (RR) (for duplicates) or a relative standard deviation (RSD). When the precision for a method is not constant over the concentration range of interest, the reported range or standard deviation will describe the concentration dependence. The dependence alternatively could be described in terms of a slope and intercept for a linear relationship, an indicated function for a nonlinear relationship, or a tabulated set of precision values for specific indicated concentrations.

Accuracy usually is expressed as percent recovery ( $P$ ) or as percent bias $(P-100)$. When accuracy is observed to be significantly concentration dependent, it could be reported in terms of a linear relationship, an alternative functional relationship, or as a table of measured values.

The method detection limit is the minimum concentration of a chemical constituent that can be measured reliably (i.e., it can be reported with 99 percent confidence that the analyte concentration is greater than zero). The method detection 1 imit is determined from a minimum of three replicate analyses of samples of a given matrix type (water, soil, etc.) spiked with the analyte of interest. The method detection limit is the standard deviation of the replicate measurements (reported in concentration units) multiplied by the appropriate Student's $t$ value for the number of replicates taken for a onetailed test at the 99 percent level of confidence. Practical quantitation limit is defined in SW-846 (EPA 1990) as the lowest concentration level that can be determined reliably within specified limits of precision and accuracy during routine laboratory operating conditions. Practical quantitation limit values are tabulated in SW-846 for various EPA approved analytical methods for evaluating solid waste. Practical quantitation limit values are matrixdependent and method-dependent. Typically, practical quantitation limits are listed as multiples of the method detection limits for specified methods and matrix types.

The performance of the analytical laboratory shall be subject to methodand anaiyte-specific quantitation limits and minimum requirements for precision, accuracy, and completeness as follows:

- Precision: The agreement among a set of replicate measurements without assumption of knowledge of the true value. Precision is estimated by means of duplicate/replicate analyses. These samples 
should contain concentrations of analyte above method detection limit, and may involve the use of matrix spikes. The most commonly used estimates of precision are the relative standard deviation (RSD) or the coefficient of variation (CV),

$$
\mathrm{RSD}=100 \mathrm{CV}=100\left(\frac{\mathrm{s}}{\overline{\mathrm{x}}}\right)
$$

where:

$\bar{x}=$ the arithmetic mean of $x_{i}$ measurements, and $s=$ standard deviation. The relative percent difference (RPD) when only two samples is available is:

$$
\operatorname{RPD}=100\left[\left(\mathrm{x}_{1}-\mathrm{x}_{2}\right) /\left\{\left(\mathrm{x}_{1}+\mathrm{x}_{2}\right) / 2\right\}\right]
$$

(EPA 1990).

- Accuracy: The closeness of agreement between an observed value and an accepted reference value. When applied to a set of observed values, accuracy will be a combination of random component and of a common systematic error (or bias) component (EPA 1990).

- Completeness: Requirements for precision and accuracy will be met for at least 95 percent of the total number of determinations on routine and quality control samples.

More stringent requirements for precision and accuracy could be specified in procedures for individual laboratory methods. In that event, the more stringent requirements also will apply as data quality objectives for this project.

Goal.s for data representativeness for soil sampling are addressed qualitatively by the specification of sample'locations and intervals in the soil sampling and analysis plan. Sample data should be comparable with other measurement data for similar samples and sample conditions. Comparability will be achieved qualitatively by using standard techniques to collect and analyze representative samples and by reporting analytical results in appropriate units.

Approved analytical procedures will require adherence to reporting techniques and units that are consistent with EPA reference methods to facilitate the comparability of data sets in terms of precision and accuracy. 
Actual achieved and/or used detection limits, and values for precision, accuracy, and completeness will be provided in all summary reports of analyses.

Failure to conform to these criteria will be documented in data summary reports as described in Section 7A.8.1, and will be evaluated in the validation process discussed in Section 7A.8.2. Corrective actions will be initiated by the Technical Lead as appropriate, as noted in Section 7A.13, in the event that the criteria initially are not achieved.

For any soil sampling activities that are to occur at the HPADS subsequent to investigative sampling, the SAP (Appendix 7C) will be updated to reflect current constituents of concern and DQOs as project requirements.

\section{A.4 PROCEDURES}

The following sections discuss sampling procedures to be used and the approvals and control of these procedures.

\section{A.4.1 Procedure Approvals and Controls}

The following sections describe the procedures referenced to support soil sampling and analysis activities.

7A.4.1.1 Hanford Site Procedures. The Hanford Site procedures that have been referenced to support soil sampling and analysis activities for HPADS Closure Areas No. 1 and No. 2 are 1 isted in the quality assurance program index in the Environmental Engineering, Geotechnology, and Permitting Function Quality Assurance Program Plan (WHC 1990a). Referenced procedures include EIIs (WHC 1988a), and qual ity requirements (QR) and quality instructions (QI) (WHC 1988b). Requirements relating to approval, revision, and distribution control of EIIs are addressed in EII 1.2, "Preparation and Revision of Environmental Investigation Instructions"; requirements applicable to QIs and QRs are addressed in QR 5.0, "Instructions, Procedures, and Drawings"; QI 5.1, "Preparation of Quality Assurance Documents:; QR 6.0, "Document Control"; and QI 6.1, "Quality Assurance Document Control". Other controlling documents that apply to preparation, review, and revision of Hanford Site analytical laboratory procedures and sample management procedures are identified under Criteria 5.00 and 6.00 in the Environmental Engineering, Geotechnology, and Permitting Function Quality Assurance Program Plan (WHC 1990a). All of the aforementioned procedures will be available on request for regulatory review.

7A.4.1.2 Participating Contractor and/or Subcontractor Procedures. As noted in Section 7A.2.1, participating contractor and/or subcontractor services may be procured at the direction of the Technical Lead. All such procurements will be subject to the applicable requirements of QR 4.0, "Procurement Document Control"; QI 4.1, "Procurement Document Control"; QI 4.2, "External Services Control"; QR 7.0, "Control of Purchased Items and Services"; QI 7.1, "Preprocurement Planning and Proposal Evaluation"; and/or QI 7.2, "Supplier Evaluation" (WHC 1988b). Whenever such services require procedural controls, 
conformance to onsite procedures, or submittal of contractor procedures for onsite review and approval before implementation, the requirement(s) will be identified in the procurement document or work order, as applicable. Analytical laboratories will be required to submit their analytical procedures as well as the current version of their internal quality assurance program plans for review and approval. The subject plans and procedures will be reviewed and approved by operations contractor's quality assurance, sample management, and analytical laboratories organization personnel, and/or other qualified personnel as determined by the Technical Lead. As necessary, al1 reviewers wi7. be qual ified per the requirements of $E I I_{1} 1.7$, "Indoctrination, Training, and Qualification" (WHC 1988a). All approved participating contractor or subcontractor procedures, $\mathrm{plans,}$ and/or manuals will be retained as project quality records in compliance with the Document Control and Records Management Manual, Section 9 (WHC 1989a); QR 17.0, "Quality Assurance Records"; and QI 17.1, "Quality Assurance Records Control" (WHC 1988b). A11 such documents will be available on request for regulatory review.

\section{A.4.2 Sampling Procedures}

Soil samples for analysis by an offsite contractor laboratory will be collected in compliance with EII 5.2, "Soil and Sediment Sampling" (WHC 1.988a). Sample numbers will be assigned as indicated in EII 5.10, "Obtaining Sample Identification Numbers and Accessing HEIS Data" (WHC 1988a). Sampling activities will be carried out in conformance with the sample identification, container type, preparation, and preservation requirements of EII 5.11, "Sample Packaging and Shipping" (WHC 1988a).

\section{A.4.3 Procedure Additions and Changes}

Additional EIIs or modifications to existing EIIs that might be required as a consequence of sampling plan requirements will be developed in compliance with EII 1.2, "Preparation and Revision of Environmental Investigations Instructions" (HHC 1988a). Should deviations from established EIIs be required to accommodate unforeseen field situations, the Field Team Leader can authorize such deviations consistent with provisions and requirements in EII 1.4, "Deviation from Environmental Investigations Instructions" (WHC 1988a). Deviations are documented, reviewed, and dispositioned by means of instruction change authorization forms; as required by EII 1.4. Other types of document change requests will be completed as required by the procedures governing their preparation and revision.

\section{A.5 SAMPLE CUSTODY}

A11 samples obtained during the course of this investigation will be controlled from the point of origin to the analytical laboratory as stipulated in EII 5.1, "Chain of Custody" (WHC 1988a). Chain-of-custody documentation al so will be maintained for the return of residual sample materials from the laboratory. Requirements and procedures will be defined in procurement documentation to subcontractor or participant contractor laboratories for the 
return of residual sample materials after completion of analysis. Laboratory chain-of-custody procedures will ensure that sample integrity and identification are maintained throughout the analytical process and will be reviewed and approved in advance as required by onsite procurement control procedures, as noted in Section 7A.4.1.2.

Results of analyses will be traceable to the original samples through a unique code or identifier, as specified in Section 7A.4. A17 analytical results will be controlled as permanent project quality records as required by QR 17.0, "Quałity. Assurance Records" (WHC. 1988b) and EII 1.6, "Records Management" (WHC 1988a).

Sample and/or data flow will be coordinated by Analytical Services (AS) the sample management organization. AS will be responsibie for tracking, controlling, and verification of in-process samples and data per Section 1.0, "Sample Tracking"; Section 1.3, "Data Package Control", and Section 1.1, "Data Package Verification" (WHC 1990b).

Al1 soil samples will be screened in the field for beta/gamma and gross alpha radioactivity in compliance with approved Hanford Site health physics procedures (WHC 1988C). Samples must be released for offsite shipment by health physics technicians before the samples can be transported to offsite laboratories for anatysis of dangerous constituents.

\section{A. 6 CALIBRATION PROCEDURES}

Calibration of contractor laboratory analytical equipment will be performed per applicable standard methods, subject to review and approval.

\section{A.7 ANALYTICAL PROCEDURES}

Specific analytical methods or procedures will be reviewed and approved before use in compliance with the procedures and procurement control requirements noted in the SAP (Appendix $7 C$ ).

\section{A.8 DATA REDUCTION, VALIDATION, AND REPORTING}

Data reduction, validation of completed laboratory data packages, reporting requirements, and review and records management are discussed in the following sections.

\section{A.8.1 Data Reduction and Data Package Preparation}

On completion of each group of analyses, the analytical laboratory will be responsible for preparing a report summarizing the analytical results. The analytical laboratory also will prepare a detailed data package that will include all information necessary to perform data validation to the extent indicated by the minimum applicable requirements of Section 7A.8.2. Data 
summary report format and data package content will be defined in procurement documentation subject to review and approval as noted in Section 7A.4.1. As a minimum, laboratory data packages will include the following:

- Sample receipt and tracking documentation (including identification of. the organization and individuals performing the analysis, the names and signatures of the responsible analysts, sample holding time requirements, references to applicable chain-of-custody procedures, and the dates of sample receipt, extraction, and analysis)

- Instrument calibration documentation, including equipment type and model, with continuing calibration data for the time period in which the analyses were performed

- Quality control data, as appropriate for the methods used, including matrix-spike/matrix-spike duplicate data, recovery percentages, precision data, laboratory blank data, and identification of any nonconformances that might have affected the Taboratory's measurement system during the time in which the analyses were performed

- The analytical results or data deliverables, including reduced data, reduction formulas or algorithms, and identification of data outliers and/or deficiencies.

Other supporting information, such as initial calibration data, reconstructed ion chromatographs, spectrograms, traffic reports, and raw data, need not be included in submittal of individual data packages. All sample data, however, will be retained by the analytical laboratory and made available for systems or program audit purposes upon the request of the operations contractor, DOE-RL, or regulatory agency representatives (Section 7A.10.0). Such data will be retained by the analytical 1aboratory through the duration of the contractual statement of work, at which time the data will be transmitted for archiving.

A completed data package will be reviewed and approved by the analytical laboratory quality assurance manager before the package is submitted to the sample management organization for validation.

The requirements of this section will be included in procurement documents and/or work orders, as appropriate, in compliance with the procurement control procedures identified in Section 7A.4.1.

\section{A.8.2 Validation}

Validation of completed laboratory data packages will be performed by the sample management organization. Data validation and reporting will be performed in conformance with requirements and procedures identified in Sample Management and Administrative Manual (WHC 1990b) and Data Validation Procedures for Chemical Analyses (WHC 1993). 
Data validators will perform a number of tasks on each sample delivery group in response to general and specific requirements identified in the data validation procedures (WHC 1993). A sample delivery group is defined as a group of samples (usually 20 or fewer) reported within a single laboratory data package. These tasks are summarized as follows:

- Take delivery of the data package, stamp the receipt date on the package, and make duplicate copies of the sample concentration reports or report forms

- Organize and review the data package for completeness as described in the data validation procedures Section 3.0 through Section 9.0 (WHC 1993) and document the completeness review on the applicable data validation checklist

- Validate the data package and qualify sample results according to the procedures and criteria described in the data validation procedures Section 3.0 through Section 10.0 (WHC 1993). Data that are rejected at any point during validation will be el iminated from further review or consideration

- Check for calculation and transcription errors, applying the frequency guidelines identified below

- Resolve any discrepancies identified during the review of the data package, including any missing data, with the Taboratory

- After the data have been validated, prepare a narrative summary of the acceptability of the data, and prepare a summary of the validated results in tabular and electronic formats

- Submit the data validation report, with the narrative summary, an electronic media copy of the data, checklists, summary forms, and the qual ified laboratory concentration reports to the Technical Lead within 21 days after receipt of the data package from the laboratory.

For this sampling and analysis project, the following frequencies will be used to check for calculation and transcription errors.

- Investigative samples and verification samples taken following soil removal--All reported laboratory results for at least 20 percent of the samples contained in the sample delivery group and 100 percent of the reported quality control samples (duplicates, matrix spikes, field blanks and any performance audit samples) will be recalculated and verified against the instrument printouts and bench sheet records (raw data). If possible, at least one-half of the samples selected for recalculation should contain positive results for the compounds analyzed. 
- Confirmatory samples--A11 reported laboratory results for 100 percent of the samples contained in the sample delivery group and 100 percent of the reported quality control samples (duplicates, matrix spikes, field blanks and any performance audit samples) will be calculated and verified against the raw data.

Reporting requirements for validation of data produced by routine and special analytical methods other than EPA reference methods (EPA 1990) will be established within applicable procedures for the individual methods, subject to review and approval as discussed in Section 7A.4.1. The reporting requirements will be in general compliance with the guidelines provided previously in this section.

\section{A.8.3 Final Review and Records Management Considerations}

All validation reports and supporting analytical data packages will be subjected to a final technical review by a qualified reviewer at the direction of the Technical Lead before submittal to regulatory agencies or inclusion in reports or technical memoranda. All validation reports, data packages, and review comments will be retained as permanent project quality records in compliance with Document Control and Records Management Manual, Section 9 (WHC 1989a) and QR 17.0, "Quality Assurance Records" (WHC 1988b).

\section{A.9 INTERNAL QUALITY CONTROL}

All analytical samples will be subject to in-process quality control measures both in the field and in the laboratory. The following types of control samples are specified in the sampling and analysis plan for the purpose of maintaining internal quality control.

- Duplicate Samples--Field duplicate samples are samples retrieved from a single sampling location using the same equipment and sampling technique, but analyzed independently. Laboratory duplicate samples are samples taken successively from the same bulb. Duplicate samples generally are used to verify the repeatability or reproducibility of the analytical data.

- Trip Blanks--A trip blank for soil sampling consists of a sample container of pure silica sand that is prepared in the laboratory, transported to the sampling site, and returned unopened for analysis with the actual soil samples. Analysis of the trip blank will eliminate false positive results for the actual samples arising from contamination during shipment.

- Equipment Blanks--An equipment blank for soil sampling consists of pure silica sand that is drawn through decontaminated sampling equipment and placed in a container identical to those used for the actual field samples. Equipment blanks are used to verify the adequacy decontamination procedures for sampling equipment in addition to the uses cited for field blanks. 
Additional quality control checks will be performed by the analytical Taboratories as follows.

- Matrix-Spiked and Matrix-Spiked Duplicate Samples--A known quantity of a representative analyte of interest is added to an aliquot (or a. replicate) of an actual sample as a measure of recovery percentage. Spike compound selection, quantities, and concentrations will be described in the laboratory's analytical procedures.

- Quality Control Reference Samples--A quality control reference sample. is prepared from an independent standard at a concentration other than that used for calibration, but within the calibration range. Reference samples provide an independent check on analytical technique and methodology.

The numbers and/or frequencies of quality control samples to be submitted and analyzed with each group of soil samples are specified in the soil sampling and analysis plan presented in Section 7.0 of the closure plan. The numbers of quality. control samples proposed in the sampling plan have been determined based on guidance presented in SW-846 (EPA 1990).

Detailed descriptions of internal quality control requirements for participating contractor or subcontractor laboratories will be provided in procurement documents or work orders in compliance with standard procedures noted in Section 7A.4.1.

\section{A.10 PERFORMANCE AND SYSTEM AUDITS}

Performance, system, and program audits will begin early in the execution of this sampling $p l a n$ and continue through completion of activities. Collectively, the audits will address quality affecting activities that include, but are not limited to, measurement accuracy; intramural and extramural analytical laboratory services; field activities; and data collection, processing, validation, and management.

Regarding offsite contractor laboratory analyses of confirmatory soil samples, performance audits of analytical accuracy will be implemented through the use of quality assurance and quality control samples.

System audit requirements wi11 be implemented in accordance with QI 10.4, "Surveillance" (WHC 1988b). Surveillances will be performed regularly throughout the course of sampling activities. Additional performance and system 'surveillances' might be scheduled as a consequence of corrective action requirements or might be performed on request. All quality affecting activities will be subject to surveillance.

Sampling plan activities could be evaluated as part of environmental restoration program-wide quality assurance audits under procedural requirements (WHC 1988b). Program audits will be conducted in accordance with 
1

QR 18.0, "Audits"; QI 18.1, "Audit Programming and Scheduling"; and QI 18.2, "Planning, Performing, Reporting, and Follow-up of Quality Audits". Program audits will be performed by qualified auditors in compliance with QI 2.5, "Qualification of Quality Assurance Program Audit Personnel" (WHC 1988b).

\section{A.11 PREVERTIVE MAINTENANCE}

A11 measurement and testing equipment used in the field and the laboratory. that directly affect the quality of analytical data will be subject to preventive maintenance measures that ensure minimization of measurement system downtime. Preventive maintenance instructions for field equipment will be as stipulated in approved operating procedures for the equipment. Laboratories will be responsible for performing or managing the maintenance of assigned analytical equipment. Maintenance requirements, spare parts 1ists, and preventive maintenance instructions will be included in individual laboratory procedures or in 1aboratory quality assurance plans, subject to review and approval. When samples are to be analyzed by a contractor or subcontractor laboratory, preventive ma intenance requirements for laboratory analytical equipment will be as defined in the contractor laboratory's quality assurance $\mathrm{plan}(\mathrm{s})$.

\section{A.12 DATA ASSESSMENT}

Analytical data will be compiled and summarized by the laboratory and forwarded to the sample management organization for validation as described in Section 7A.8.2 before the data can be used in any assessment activities. Assessments could inciude various statistical and probabilistic techniques to compare and/or analyze data. The statistical methodologies and assumptions that are to be used to evaluate data will be identified in written instructions that are to be signed, dated, and retained as project quality records in compliance with EII 1.6, "Records Management" (WHC 1988a) and QR 17.0, "Quality Assurance Records" (WHC 1988b). These instructions will be documented in the final report for each sampling and analysis project.

\section{A.13 CORRECTIVE ACTION}

Corrective actions required as a result of surveillance reports, nonconformance reports, or audit activities will be documented and dispositioned as required by QR 16.0, "Corrective Action"; QI 16.1, "Trending/Trend Analysis"; and QI 16.2, "Corrective Action Reporting" (WHC 1988b). Primary responsibilities for corrective action resolution will be assigned to the Technical Lead and the quality assurance coordinator. other needs for corrections to measurement systems, procedures, or plans that are identified as a result of routine review processes will be resolved as stipulated in applicable procedures or referred to the Technical Lead for resolution. Copies of all surveillance, nonconformance, audit, and corrective action documentation will be retained as project quality assurance records. 


\section{7A.14 QUALITY ASSURANCE REPORTS}

As indicated in Sections $7 A .10$ and $7 A .13$, project activities will be assessed regularly by audit and surveillance processes. At the conclusion of a given sampling and analysis project, all related field and 1aboratory data, raw data, reports, surveillance reports, nonconformance reports, audit reports, and corrective action documentation will be transferred for archival to the Hanford Site Records Holding Area (if documentation has not been transmitted previously). In the event that original quality-affecting documents are to be retained and/or controll led by others, legible copies. will be transmitted to the Records Holding Area for inclusion in the project record file. 
DOE/RL-92-39, Rev. 1

$12 / 15 / 94$

APPENDIX 7B

2

4

TRAINING COURSE DESCRIPTIONS 
DOE/RL-92-39, Rev. 1

$12 / 15 / 94$

1

2

3

4

\section{APPENDIX 7B}

This appendix contains a training matrix and brief course descriptions. 


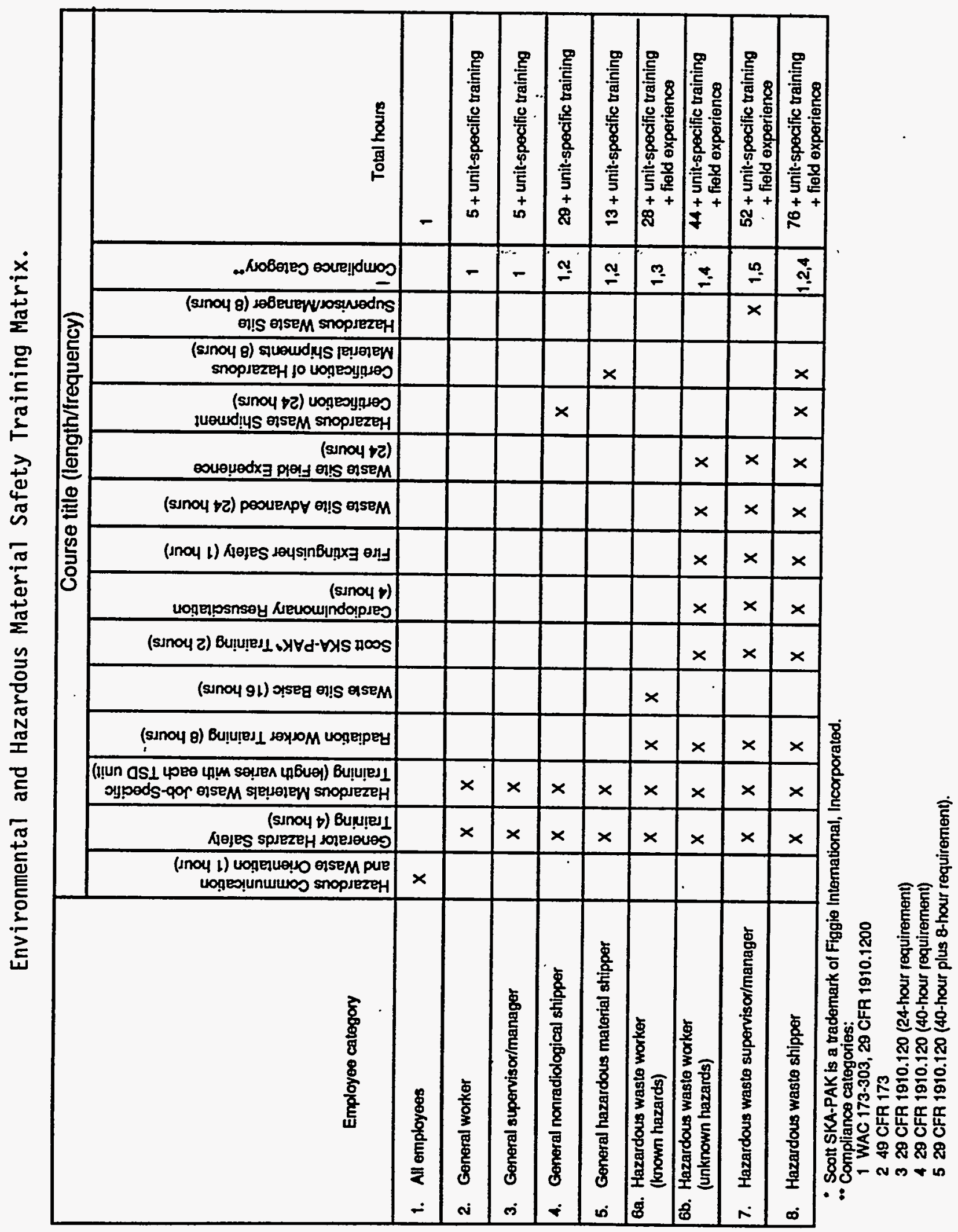


DOE/RL-92-39, Rev. 1

$12 / 15 / 94$

This page intentionally left blank. 


\begin{tabular}{|c|c|c|}
\hline \multicolumn{3}{|c|}{ ENVIRONMENTAL AND HAZARDOUS MATERIAL SAFETY TRAINING } \\
\hline & Course name & Description \\
\hline 1. & $\begin{array}{l}\text { Hazard Communication and } \\
\text { Waste Orientation }\end{array}$ & $\begin{array}{l}\text { Course provides an overview of the } \\
\text { federal and appl icable hazard } \\
\text { communication programs and hazardous } \\
\text { and/or dangerous waste disposal programs. }\end{array}$ \\
\hline 2. & $\begin{array}{l}\text { Generator Hazards Safety } \\
\text { Training }\end{array}$ & $\begin{array}{l}\text { Course provides the hazardous and/or } \\
\text { dangerous material/waste worker with the } \\
\text { fundamentals for use and disposal of } \\
\text { hazardous and/or dangerous materials. }\end{array}$ \\
\hline 3. & $\begin{array}{l}\text { Hazardous Materials/Waste } \\
\text { Job-Specific Training }\end{array}$ & $\begin{array}{l}\text { Course provides specific information on } \\
\text { hazardous and/or dangerous chemicals and } \\
\text { waste management at the employees' } \\
\text { TSD unit. }\end{array}$ \\
\hline 4. & $\begin{array}{l}\text { Initial Radiation Worker } \\
\text { Training }\end{array}$ & $\begin{array}{l}\text { Course provides radiation workers with } \\
\text { the fundamentals of radiation protection } \\
\text { and the proper procedures for maintaining } \\
\text { exposures ALARA. }\end{array}$ \\
\hline 5. & Waste Site Basics & $\begin{array}{l}\text { Course provides required information for } \\
\text { the safe operation of hazardous and/or } \\
\text { dangerous waste TSD units regulated under } \\
40 \text { CFR } 264 \text { and } 265 \text { pursuant to RCRA and } \\
\text { HAC } 173-303 \text {. }\end{array}$ \\
\hline 6. & $\begin{array}{l}\text { Scott 'SKA-PAK'1 } \\
\text { Training-SKA }\end{array}$ & $\begin{array}{l}\text { Course instructs employees in the proper } \\
\text { use of the Scott 'SKA-PAK' for entry, } \\
\text { exit, or work in conditions 'immediately } \\
\text { dangerous to } 1 \text { ife and health' and } \\
\text { instructs employees to recognize and } \\
\text { handle emergencies. }\end{array}$ \\
\hline 7. & $\begin{array}{l}\text { Cardiopulmonary } \\
\text { Resuscitation }\end{array}$ & $\begin{array}{l}\text { Course of the American Heart Association } \\
\text { that provides certification in } \\
\text { cardiopulmonary resuscitation for the } \\
\text { single rescuer (Heartsaver Course). }\end{array}$ \\
\hline
\end{tabular}

${ }^{1}$ Scott SKA-PAK is a trademark of Figgie International, Incorporated. 


\begin{tabular}{|c|c|c|}
\hline & Course name & Description \\
\hline 8. & Fire Extinguisher Safety & $\begin{array}{l}\text { Course provides videocassette } \\
\text { presentation that covers types of } \\
\text { portable fire extinguishers and the } \\
\text { proper usage for each. }\end{array}$ \\
\hline 9. & Waste Site-Advanced & $\begin{array}{l}\text { Course provides environmental safety } \\
\text { information for RCRA and/or CERCLA. } \\
\text { operations and sites. Topics include } \\
\text { regulations and acronyms, occupational } \\
\text { health and safety, chemical hazard } \\
\text { information, toxicology, personal } \\
\text { protective equipment and respirators, } \\
\text { site safety, decontamination, and } \\
\text { chemical monitoring instrumentation. }\end{array}$ \\
\hline 10. & $\begin{array}{l}\text { Waste Site Field } \\
\text { Experience }\end{array}$ & $\begin{array}{l}\text { Course is a 3-day field experience under } \\
\text { the direct supervision of a trained, } \\
\text { experienced supervisor. }\end{array}$ \\
\hline 11. & $\begin{array}{l}\text { Hazardous Waste Shipment } \\
\text { Certification }\end{array}$ & $\begin{array}{l}\text { Course provides an indepth look at } \\
\text { federal, state, and Hanford Site } \\
\text { requirements for nonradioactive hazardous } \\
\text { and/or dangerous waste management and } \\
\text { transportation. }\end{array}$ \\
\hline 12. & $\begin{array}{l}\text { Certification of } \\
\text { Hazardous Material } \\
\text { Shipments }\end{array}$ & $\begin{array}{l}\text { Course provides training in dangerous } \\
\text { material regulation of the } \\
\text { U.S. Department of Transportation, as } \\
\text { required by law, to those who certify the } \\
\text { compliance of Hanford Site hazardous } \\
\text { and/or dangerous material shipments. The } \\
\text { main focus is on the proper preparation } \\
\text { and release of radioactive material } \\
\text { shipments. }\end{array}$ \\
\hline 13. & $\begin{array}{l}\text { Hazardous Waste Site } \\
\text { Supervisor/Manager }\end{array}$ & $\begin{array}{l}\text { Course provides specialized training to } \\
\text { operations and site management in the } \\
\text { following programs: safety and health, } \\
\text { employee training, personal protective } \\
\text { equipment, spill containment, and health } \\
\text { hazard monitoring procedures and } \\
\text { techniques. }\end{array}$ \\
\hline
\end{tabular}


DOE/RL-92-39, Rev. 1

\section{APPERDIX 7C}

2

3
4

\section{SAMPLING AND ANALYSIS PLAN}


DOE/RL-92-39, Rev. 1

This page intentionally left blank. 
WHC-SD-EN-TI-284, Rev. 0

CONTENTS

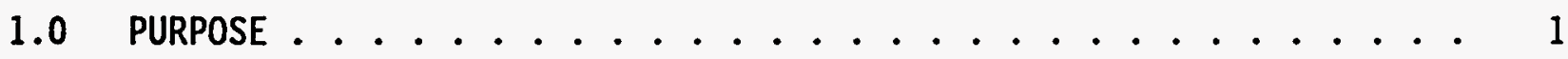

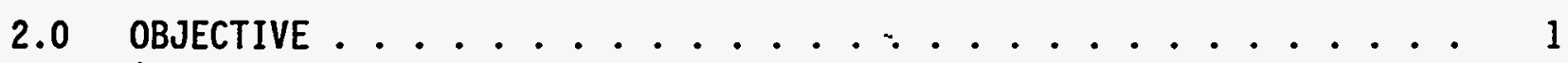

3.0 SITE DESCRIPTION/BACKGROUND ............... 5

4.0 SCOPE OF HORK ................... 5

5.0 SAMPLING AND FIELD ACTIVITIES . . . . . . . . . . 6

6.0 LABORATORY ANALYSIS ................. 6

7.0 REGULATORY AND HANFORD SITE COMPLIANCE . . . . . . . 6

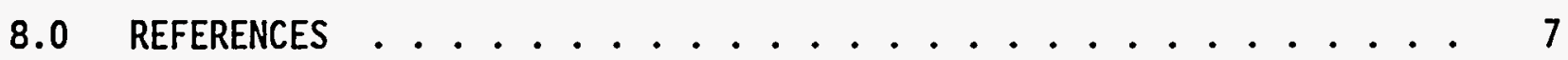

\section{ATTACHMENT}

1 Metric Conversion Chart ...............Att-1

\section{FIGURES}

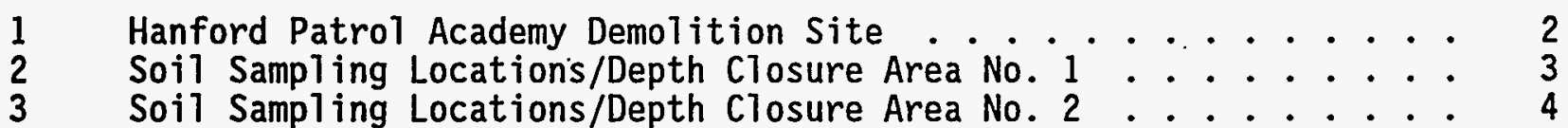


WHC-SD-EN-TI-284, Rev. 0

\section{HANFORD PATROL ACADEMY DEMOLITION SITES SAMPLING ANALYSIS PLAN}

\subsection{PURPOSE}

This document provides guidance for sampling and analysis activities associated with the proposed Resource Conservation and Recovery Act of 1976 (RCRA) clean closure of the Hanford Patrol Academy Demolition Sites (HPADS) (Figure 1). This document is a supplement to Hanford Patrol Academy Demolitian Si.tes Closure. Plan (DOE-RL 19.92), and should be used in conjunction with the Environmental Investigations and Site Characterization Manual (WHC 1988) for specific procedures. The samples will be collected by environmental field services and shipped offsite for analysis.

A metric conversion chart is provided as a tool to aid in conversion (Attachment 1).

\subsection{OBJECTIVE}

Several soil samples will be taken from specific locations in Closure Areas No. 1 and 2 (Figure 1). The objective of this soil sampling event is to facilitate a RCRA clean closure of the HPADS by verifying that the concentrations of all detonation activity contaminants are below action levels. Action levels are defined as levels above the Hanford Site soil background levels identified in Hanford Site Background: Part 1, Soil Background for Nonradioactive Analytes (DOE-RL 1993) and Model Toxic Control Act (HAC 173-340) residential levels. If analysis determines that levels are above both guidelines, a phase two investigation will be developed. This is not anticipated because of the efficiency of detonation reactions and exposure to the environment.

\subsection{CLOSURE AREA NO. 1}

Twelve soil samples will be taken from specific locations (Figure 2) within Closure Area No. 1. Closure Area No. 1 is immediately south of the known distance target range at the bottom of the slope and measures approximately 35 by 114 feet. Closure Area No. 1 consists of two distinct regions, $A$ and $B$. Region $A$ is where the actual detonation events occurred. Five soil samples will be collected in Region A (Figure 2). Region $B$ is where any explosive chemical products would have been dispersed after subsequent grading activities. Seven samples will be collected in Region B (Figure 2).

\subsection{CLOSURE AREA NO. 2}

Closure Area No. 2 consists of a detonation pit measuring approximately 10 feet in diameter and 1.5 feet deep. Fifteen soil samples will be taken from specific locations (Figure 3 ) within a 15 -foot radius centered about the detonation pit. 


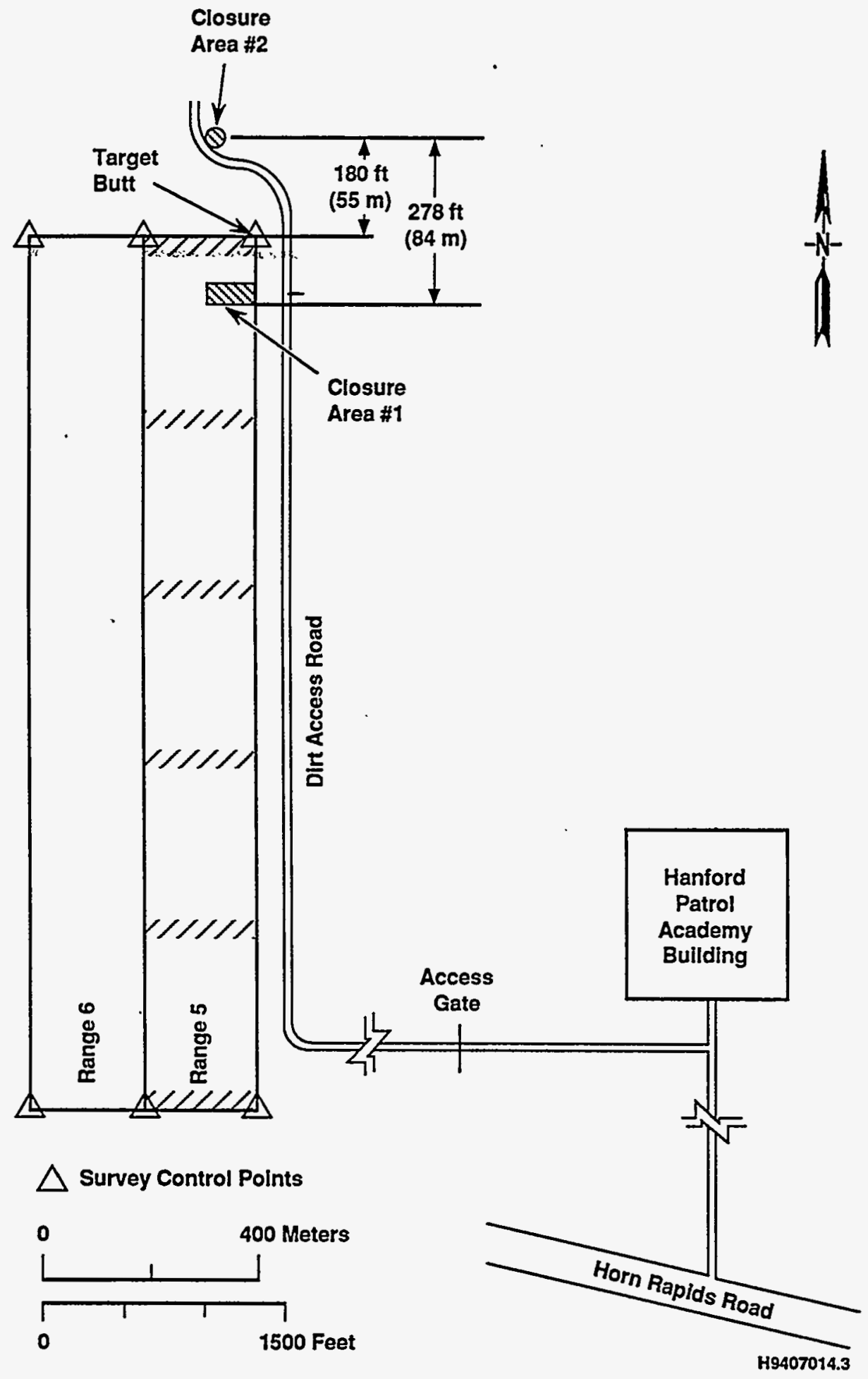

Figure 1. Hanford Patrol Academy Demolition Sites. 
WHC-SD-EN-TI-284, Rev. 0

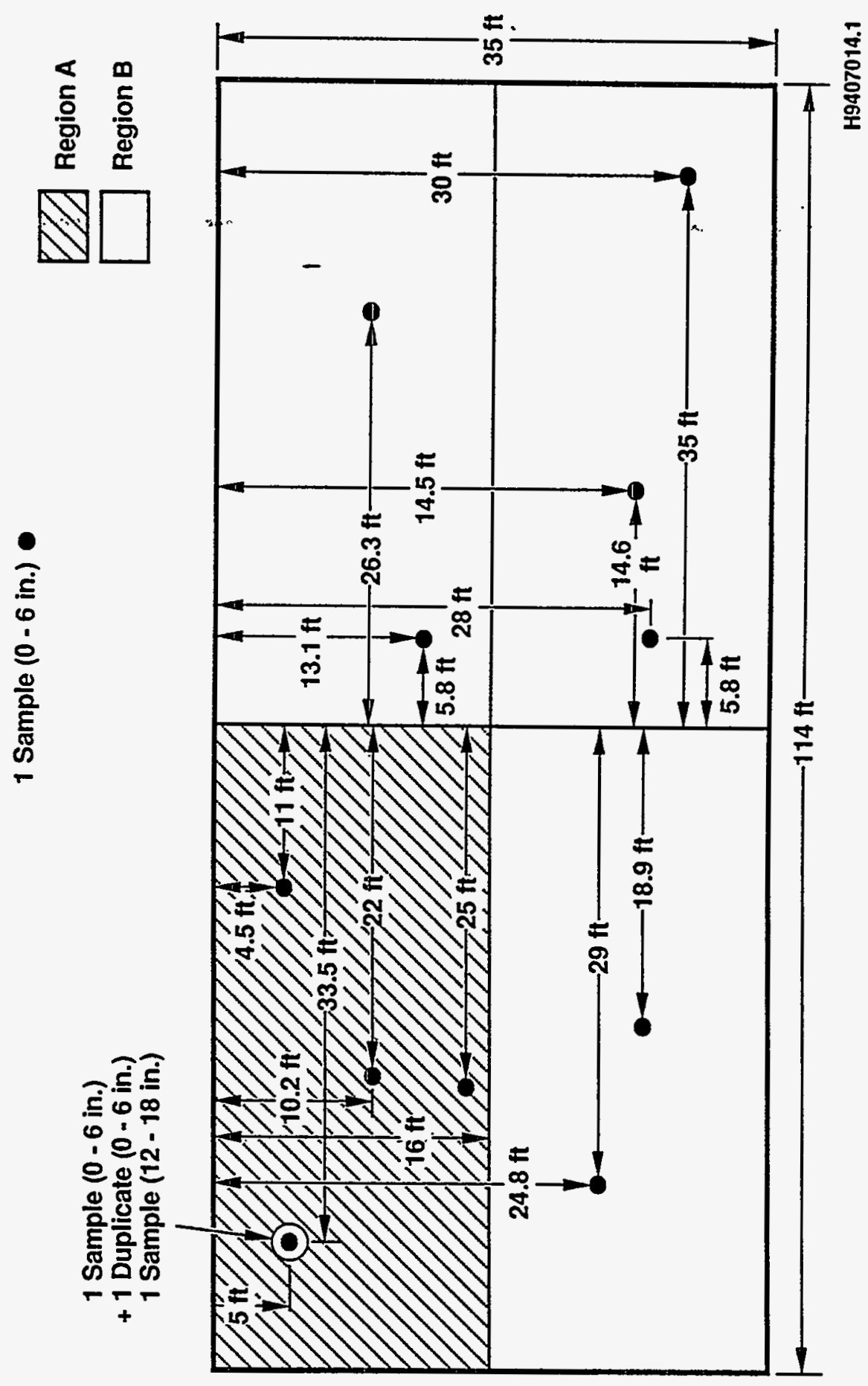

Figure 2. Soil Sampling Locations/Depth Closure Area No. 1. 


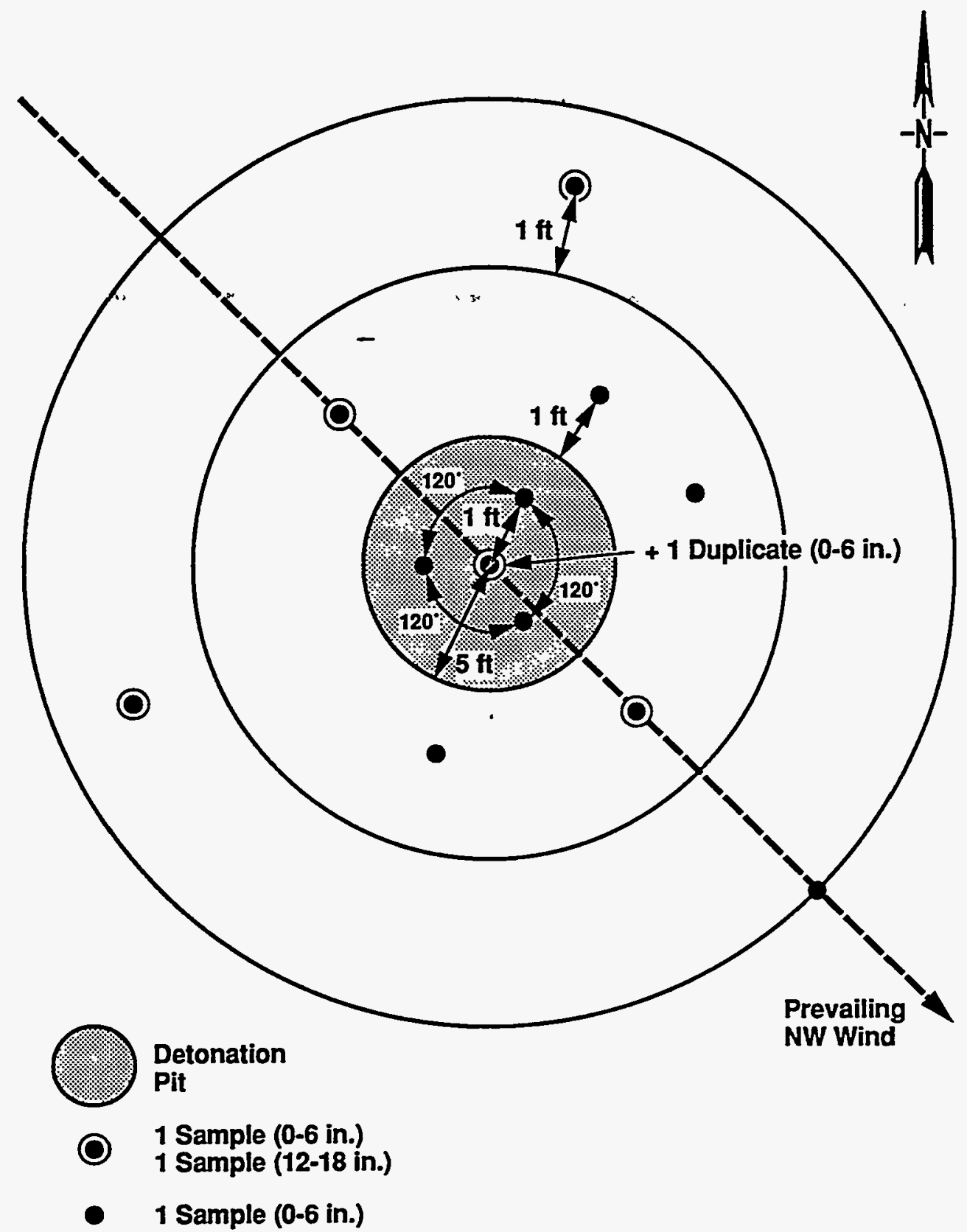

H9407032.1

Figure 3. Soil Sampling Locations/Depth Closure Area No. 2. 
WHC-SD-EN-TI-284, Rev. 0

\subsection{SITE DESCRIPTION/BACKGROUND}

The HPADS are about 2 miles southwest of the 300 Area and about 0.5 mile north of Horn Rapids Road. The HPADS consist of Closure Areas No. 1 and 2, which were used for the demolition of discarded explosive and shock-sensitive chemicals. Closure Area No. 1 was used from 1975 through 1984 and Closure Area No. 2 was used from 1984 through 1991. During the detonation events at Closure Area No. 1, the individual chemical containers were placed on the ground near the invert of the target butt. The containers were then detonated using M14. rifle fire. Closure Area.No. 2 is a crater 10 feet in diameter and approximately 1.5 feet deep. Onsite personnel placed the individual containers in the detonation pit. The City of Richland Bomb Squad then wrapped detonation cord around the containers and initiated the detonation with electric blasting caps. Both closure areas are currently roped off and marked with signs that read "dangerous waste".

\subsection{SCOPE OF WORK}

Twenty-seven soil characterization samples will be taken by hand from locations at the HPADS (Figures 2 and 3 ).

A11 sampling activities will be conducted in accordance with the following environmental investigations instructions (EII) procedures (WHC 1988):

- EII 1.1, Hazardous Waste Site Entry Requirements

- EII 1.13, Environmental Readiness Review

- EII 1.5, Field Logbooks

- EII 5.1, Chain of Custody

- EII 5.2, Soil and Sediment Sampling

- EII 5.5, 1706 KE Laboratory Decontamination of RCRA/CERCLA Sampling Equipment

- EII 5.10, Obtaining Sample Identification Numbers and Accessing HEIS Data

- $\quad$ EII 5.11, Sample Packaging and Shipping

- EII 14.1, Analytical Laboratory Data Management. 
WHC-SD-EN-TI-284, Rev. 0

\subsection{SAMPLING AND FIELD ACTIVITIES}

This section discusses Task 1 , Sampling of the HPADS.

\subsection{SUBTASK IA - SAMPLE LOCATION DETERMINATIONS}

\subsubsection{Closure Area No. 1}

The sampling surface in Closure Area No. 1 will be cleaned of windblown sand and fareign debris. The 12 sampling locations in Closure Area No. 1 will be appropriately marked (Figure 2).

\subsubsection{Closure Area No. 2}

The blasting surface in Closure Area No. 2 will be reconstructed by removing windblown sand and foreign debris. The 17 sampling locations will be appropriately marked (Figure 3 ). Sample depths within Closure Area No. 2 (Figure 3, shaded area) are based upon the reconstructed crater.

\subsection{SUBTASK 1B - SAMPLING}

Engineering support personnel will use hand tools to obtain soil samples in accordance with information provided in Figures 2 and 3 . Al1 samples will be packaged, handled, and shipped in accordance with WHC (1988).

\subsection{LABORATORY ANALYSIS}

Samples collected for chemical analysis will be analyzed using SH-846 methods (EPA 1986) and approved U.S. Environmental Protection Agency (EPA) 300 series methods (EPA 1983). The contaminants of concern and the methods used for testing are:

- Volatile organic analysis, EPA Method 8240

- Semivolatile organic analysis, EPA Method 8270

- Detonation residue, EPA Method 8330

- Anions, EPA Method 300.0

- Metals, EPA Method 6010

- Totar nitrogen, EPA Method 353.1-2.

\subsection{REGULATORY AND HANFORD SITE COMPLIANCE}

Field quality control samples will be collected by the sampling scientist and documented in the sampling logbook in accordance with EII 1.5, "Field Logbooks" (WHC 1988). The following are the field quality control samples to be collected: 
- One duplicate sample in Region A of Closure Area No. 1 (0 to 6inch depth) for fult anatysis

- One duplicate sample at center of pit in Closure Area No. 2 (0 to 6 -inch depth) for full analysis

- One equipment blank (clean silica sand) for full analysis

- One trip blank (clean silica sand) for volatile organic analysis onty.

\subsection{REFERENCES}

DOE-RL, 1992, Hanford Patrol Academy Demolition Sites Closure Plan, DOE/RL-92-39, U.S. Department of Energy, Richland Operations Office, Richl and, Washington.

DOE-RL, 1993, Hanford Site Background: Part 1, Soi7 Background for Nonradioactive Analytes, DOE/RL-92-24, Rev. 1, U. S. Department of Energy, Richland Operations Office, Richland, Washington.

EPA, 1983, Methods for Chemical Analysis of Water and Waste, 600/4-79-020, U.S. Environmental Protection Agency, Washington, D.C.

EPA, 1986, as amended, Test Methods for Evaluating Solid Waste:

Physical/Chemical Methods, SW-846, 3rd Edition, U.S. Environmental Protection Agency, Washington, D.C.

WHC, 1988, Environmental Investigations and Site Characterization Manual, WHC-CM-7-7, Westinghouse Hanford Company, Richland, Washington.

WAC 173-340, Model Toxics Control Act Cleanup Regulations, as amended, Washington State Department of Ecology, Olympia, Washington.

Resource Conservation and Recovery Act of 1976, 42 USC 6901 et seq.

Comprehensive Environmental Response, Compensation, and Recovery Act of 1980, 42 USC 9601 et seq. 


\section{METRIC CONVERSION CHART}

Into metric units

Out of metric units

\begin{tabular}{|c|c|c|c|c|c|}
\hline If you know & $\begin{array}{l}\text { Multiply } \\
\text { by }\end{array}$ & To get & If you know & $\begin{array}{c}\text { Multiply } \\
\text { by }\end{array}$ & To get \\
\hline \multicolumn{3}{|c|}{ Length } & \multicolumn{3}{|c|}{ Length } \\
\hline inches & 25.40 & millimeters & millimeters & 0.0393 & inches \\
\hline inches & 2.54 & centimeters & centimeters & 0.393 & inches \\
\hline feet & 0.3048 & meters & meters & 3.2808 & feet \\
\hline yards & 0.914 & meters & meters & 1.09 & yards \\
\hline miles & 1.609 & kilometers & kilometers & 0.62 & miles \\
\hline \multicolumn{3}{|c|}{ Area } & \multicolumn{3}{|c|}{ Area } \\
\hline $\begin{array}{l}\text { square } \\
\text { inches }\end{array}$ & 6.4516 & $\begin{array}{l}\text { square } \\
\text { centimeters }\end{array}$ & $\begin{array}{l}\text { square } \\
\text { centimeters }\end{array}$ & 0.155 & $\begin{array}{l}\text { square } \\
\text { inches }\end{array}$ \\
\hline square feet & 0.092 & $\begin{array}{l}\text { square } \\
\text { meters }\end{array}$ & $\begin{array}{l}\text { square } \\
\text { meters }\end{array}$ & 10.7639 & $\begin{array}{l}\text { square } \\
\text { feet }\end{array}$ \\
\hline $\begin{array}{l}\text { square } \\
\text { yards }\end{array}$ & 0.836 & $\begin{array}{l}\text { square } \\
\text { meters }\end{array}$ & $\begin{array}{l}\text { square } \\
\text { meters }\end{array}$ & 1.20 & $\begin{array}{l}\text { square } \\
\text { yards }\end{array}$ \\
\hline $\begin{array}{l}\text { square } \\
\text { miles }\end{array}$ & 2.59 & $\begin{array}{l}\text { square } \\
\text { kilometers }\end{array}$ & $\begin{array}{l}\text { square } \\
\text { kilometers }\end{array}$ & 0.39 & $\begin{array}{l}\text { square } \\
\text { miles }\end{array}$ \\
\hline acres & 0.404 & hectares & hectares & 2.471 & acres \\
\hline \multicolumn{3}{|c|}{ Mass (weight) } & \multicolumn{3}{|c|}{ Mass (weight) } \\
\hline ounces & 28.35 & grams & grams & 0.0352 & ounces \\
\hline pounds & 0.453 & kilograms & kilograms & 2.2046 & pounds \\
\hline short ton & 0.907 & metric ton & metric ton & 1.10 & short ton \\
\hline \multicolumn{3}{|c|}{ Volume } & \multicolumn{3}{|c|}{ Volume } \\
\hline $\begin{array}{l}\text { fluid } \\
\text { ounces }\end{array}$ & 29.57 & millititers & milliliters & 0.03 & $\begin{array}{l}\text { fluid } \\
\text { ounces }\end{array}$ \\
\hline quarts & 0.95 & liters & liters & 1.057 & quarts \\
\hline gallons & 3.79 & 1iters & Titers & 0.26 & gallons \\
\hline cubic feet & 0.03 & $\begin{array}{l}\text { cubic } \\
\text { meters }\end{array}$ & $\begin{array}{l}\text { cubic } \\
\text { meters }\end{array}$ & 35.3147 & cubic feet \\
\hline cubic yards & 0.76 & $\begin{array}{l}\text { cubic } \\
\text { meters }\end{array}$ & $\begin{array}{l}\text { cubic } \\
\text { meters }\end{array}$ & 1.308 & $\begin{array}{l}\text { cubic } \\
\text { yards }\end{array}$ \\
\hline \multicolumn{3}{|c|}{ Temperature } & \multicolumn{3}{|c|}{ Temperature } \\
\hline Fahrenheit & $\begin{array}{l}\text { subtract } \\
32 \text { then } \\
\text { multiply } \\
\text { by } 5 / 9 \text { ths }\end{array}$ & Celsius & Celsius & $\begin{array}{l}\text { multiply } \\
\text { by } \\
9 / 5 \text { ths } \\
\text { then add } \\
32\end{array}$ & Fahrenheit \\
\hline
\end{tabular}

Source: Engineering Unit Conversions, M. R. Lindeburg, PE., Second Ed., 1990, Professional Publications, Inc., Belmont, California. 